\title{
Bench-Stable Electrophilic Indole and Pyrrole Reagents: Serendipitous Discovery and Use in C-H Functionalization
}

\author{
Paola Caramenti, ${ }^{a}$ and Jerome Waser ${ }^{*, a}$ \\ a Laboratory of Catalysis and Organic Synthesis, Institute of Chemical Sciences and Engineering, Ecole Polytechnique Fédérale de Lausanne, EPFL SB ISIC \\ LCSO, Av. Forel 2, 1015 Lausanne, Switzerland, jerome.waser@epfl.ch

\begin{abstract}
The development of reagents allowing the reversal of the standard reactivity (Umpolung) of small building blocks is an important field of research in chemistry, as it allows increasing the flexibility of organic synthesis. Indoles and pyrroles are ubiquitous heterocycles in natural products and drugs. They are usually functionalized making use of their high nucleophilicity. In contrast, only few methods are based on the use of electrophilic indole and pyrrole synthons, as the needed reagents are highly unstable or can be used only with a very narrow scope. Herein, we report the serendipitous discovery and first use in the C-H functionalization of arenes of IndoleBX and PyrroleBX, new thermally highly stable benziodoxol(on)e hypervalent iodine reagents. IndoleBX and PyrroleBX could be obtained in one step from the corresponding heterocycles and acetoxy benziodoxolone using a Lewis acid catalyst. The mild reactions conditions allowed the introduction of a broad range of functional groups, including ethers, halogens and boronic esters. The new reagents could then be used in the rhodium- and ruthenium- catalyzed C-H heteroarylation of arene rings bearing heterocyclic or benzamide directing groups.
\end{abstract} \\ Such transformations could not be realized using previously reported $\mathrm{C}-\mathrm{H}$ functionalization procedures.
}

Keywords: Heterocycles • Umpolung $\cdot$ Hypervalent lodine $•$ Indole $\cdot \mathrm{C}-\mathrm{H}$ activation

\section{Introduction}

Pyrroles and indoles are among the most ubiquitous azoles present in nature. These heterocycles can be found in pharmaceuticals, ${ }^{[1]}$ fragrances, agrochemicals and natural products (scheme 1a). ${ }^{[2]}$ First discovered in the late $19^{\text {th }}$ century by Bayer, ${ }^{[3]}$ their popularity increased when many indolecontaining alkaloids such as Reserpine $(\mathbf{1})^{[4]}$ or Dictyodendrins A-E (2) $)^{[5,6]}$ were found to be biologically active. Indole and pyrrole rings are also well represented in top selling drugs such as Atorvastatin (3) and Fluvastatin (4). ${ }^{[7]}$ As a consequence of this interest, countless methods for both synthesis and functionalization of indoles and pyrroles were developed..$^{8-}$ ${ }^{10]}$ As they are electron-rich heterocycles, they undergo electrophilic aromatic substitutions at a higher rate than the benzene ring. ${ }^{[1]}$ Of particular interest are arylation methods, as arylated heterocycles have found widespread applications in synthetic and medicinal chemistry. The most often used approach is cross-coupling, but it requires prefunctionalized building blocks and generates a significant amount of waste.

Recently, strong interest arouses in direct $\mathrm{C}-\mathrm{H}$ arylation, as a more direct method for heterocyclic functionalization (scheme 1b). Most works have made use of the high nucleophilicity of indoles and pyrroles for $\mathrm{C}-\mathrm{H}$ functionalization with activated electrophilic arene partners, such as halides. ${ }^{[12]}$ Of particular importance are the works of Sanford, ${ }^{[13]}$ Gaunt, ${ }^{[14]}$ and coworkers, in which electron-rich indoles and pyrroles are coupled with hypervalent iodonium salts in the presence of catalytic amounts of $\mathrm{Pd}(\mathrm{II})$ or $\mathrm{Cu}(\mathrm{I})$ under mild reaction conditions. Ackermann and coworkers also reported a metal free arylation of indoles with aryl iodonium salts. ${ }^{[15]}$ These works among others fully establish aryl iodonium salts as exceptional reagents for $\mathrm{C}-\mathrm{H}$ functionalization under mild conditions. ${ }^{[16]}$
However, the nearly exclusive focus on the innate nucleophilicity of indoles and pyrroles to couple them with electrophilic pre-activated arenes fundamentally limits the diversity of accessible structures. In this respect, Fagnou and co-workers reported the elegant direct oxidative coupling of two $\mathrm{C}-\mathrm{H}$ bonds between arenes and indoles, which allows also the use of electron-rich partners (scheme 1b). ${ }^{[17,18]}$ However, this approach required a large excess of the arene and high temperatures, often resulting in regioisomeric mixtures of products and low functional group tolerance. More efficient processes were possible only in special cases, such as coupling with activated azoles ${ }^{[19-24]}$ or perfluorinated benzene rings. ${ }^{[25,26]}$ Therefore, the availability of electrophilic indole or pyrrole synthons able to react with nucleophilic arene partners by $\mathrm{C}-\mathrm{H}$ functionalization would tremendously enhance the range of accessible arylated heterocycles.

Nevertheless, accessing such synthons constitutes a formidable challenge. Only few successful approaches with a narrow scope of electronically biased substrates or relying on reactive electrophilic indolyl intermediates generated in situ have been reported. ${ }^{[27]}$ Hypervalent lodine reagents have been frequently applied to achieve the Umpolung of different nucleophiles. ${ }^{[28-32]}$ In particular, the Umpolung of indoles and pyrroles was realized by Kita and co-workers by in situ generation of non-isolable hypervalent iodine intermediates from phenyliodonium ditrifluoroacetate (PIDA). ${ }^{[3]}$ This approach was used in the total synthesis of indole alkaloids. ${ }^{[34]}$ These reports showed the possibility of nucleophilic functionalization of electron-rich heterocycles, via in-situ formation of hypervalent iodine intermediates. Nevertheless, the instability of the formed intermediates limited the scope and applications of these methods. Unfortunately, only few examples of isolable indole and pyrrole-based iodonium salts have been reported. 
a) Indoles and pyrroles in biologically active compounds

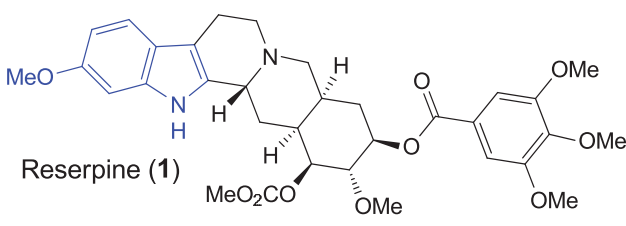

Dictyodendrins A-E (2) Telomerase inhibitor activity

b) Arylation of indoles/pyrroles: State of the art and limitations

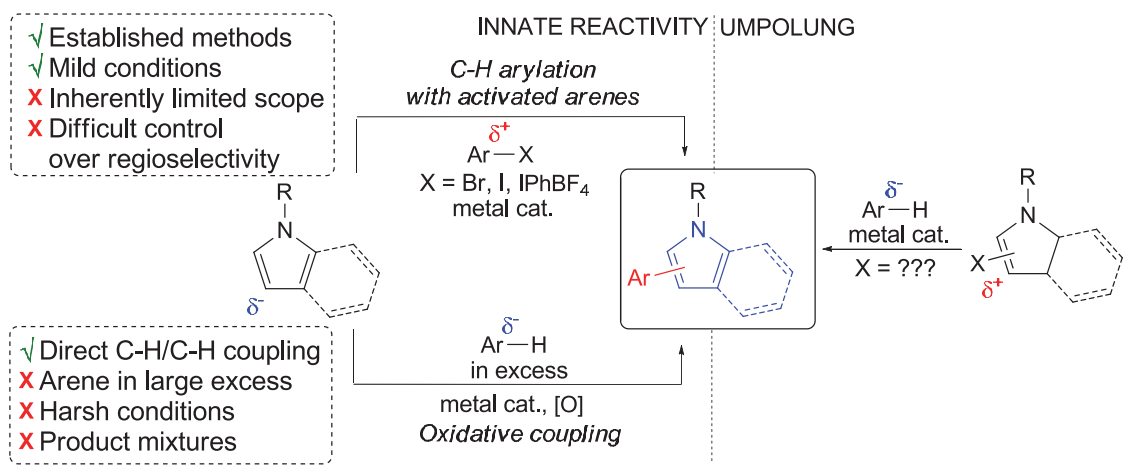

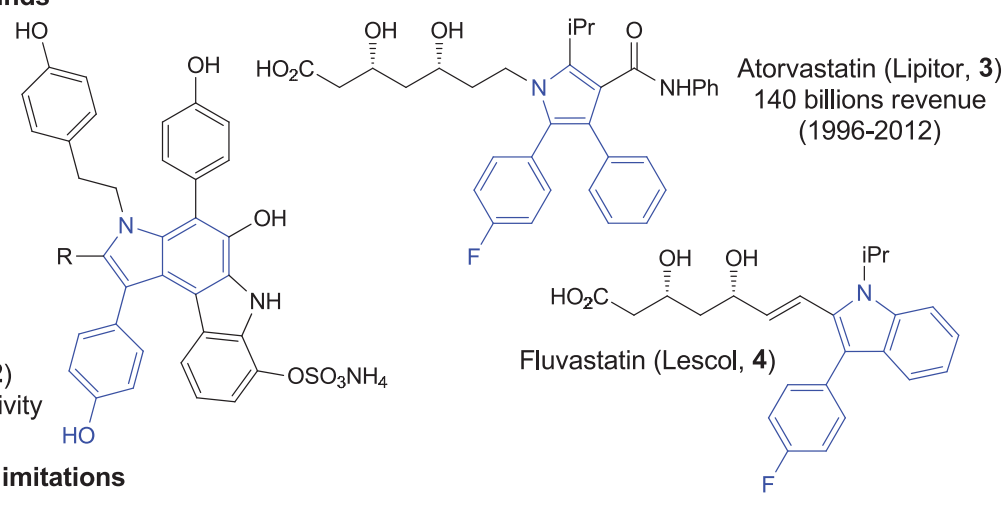

Electrophilic indoles and pyrroles: Unexploited potential to access new chemical space

$\sqrt{ }$ Complementary scope

$\sqrt{ }$ Control over regioselectivity

XUnstable, difficult to access reagents

XNo reported examples

Scheme 1. a) Examples of indole- and pyrrole-containing natural products and top selling drugs. b) State of the Art of transition metal catalyzed indole $\mathrm{C}-\mathrm{H}$ arylation.

Indole-based iodonium salts were first reported in the 70s by Neiland and coworkers, ${ }^{[35,36]}$ followed by the groups of Kost, ${ }^{[37,38]}$ and Moriarty. ${ }^{[39]} \mathrm{A}$ multi-step procedure via a spontaneously self-detonating betaine intermediate was required to access these reagents: the obtained salts were unstable and could again be used only for a limited range of transformations. Only halogenation ${ }^{[37,38]}$ and alkylation ${ }^{[39]}$ with organolithium reagents were reported. Recently, more stable azole-based iodonium reagents were reported by Suna and coworkers. ${ }^{[40,41]}$ Nevertheless, the azoles needed to be deactivated by electronwithdrawing groups in order to stabilize the reagents. Suna and coworkers reported two applications of these reagents: a $\mathrm{Cu}(\mathrm{I})$-catalyzed azidation in which the final product was converted in situ via click chemistry, ${ }^{[40]}$ and an amination. ${ }^{[41]}$ More stable iodonium salts were reported by Moriyama, ${ }^{[42,43]}$ $\mathrm{Kita}^{[44]}$ and coworkers, but again, an electron-withdrawing group on the nitrogen was required to stabilize the reagents. Furthermore, a recent example of de-aromatization of indoles by using Neiland's $\mathrm{NH}$-indole iodonium salt was reported by Liu et al. ${ }^{[45]}$ This still constitutes the only example of metal catalysis involving indole-based iodonium salts not stabilized by electron-withdrawing protecting groups. To the best of our knowledge, indole and pyrrole iodonium salts have never been used in the metal-catalyzed arylation of $\mathrm{C}-\mathrm{H}$ bonds, probably because of their limited stability, especially at higher temperatures. Clearly, the development of better indole and pyrrole electrophilic synthons combining high reactivity with enhanced stability is urgently needed.
Since several years, our group has investigated the reactivity of more stable cyclic hypervalent iodine reagents in group transfer reactions. ${ }^{[32]}$ In particular, EthynylBenziodoXol(on)es (EBX) reagents have been used successfully for the Umpolung of alkynes. ${ }^{[46,47]}$ They were especially employed by us and others in metal-catalyzed $\mathrm{C}-\mathrm{H}$ alkynylation of (hetero)arenes (scheme 2a). ${ }^{[48-59]}$ Recently, we have reported preliminary results on the synthesis and use of new stable indole- and pyrrolebenziodoxol(on)e reagents (Indole- and Pyrrole- BX) and their use in the $\mathrm{Rh}(\mathrm{III})$ - and $\mathrm{Ru}(\mathrm{II})$-catalyzed $\mathrm{C}-\mathrm{H}$ functionalizations of arenes. ${ }^{[60]}$ Herein, we present a full account of this work, including: (1) the serendipitous discovery of the reagents when attempting the development of further domino transformations for the synthesis of functionalized indoles based on our previous work in this area ${ }^{[61-64]}$ (scheme $\left.2 b\right),(2)$ a detailed report on the synthesis and structure analysis of both benziodoxole and benziodoxolone heterocyclic reagents and (3) details on the optimization and scope of the new $\mathrm{C}-\mathrm{H}$ functionalization reactions (scheme $2 \mathrm{c}$ ).

\section{Results and Discussion}

While direct functionalization methods of heterocyclic rings are well developed, they remain limited to more reactive $\mathrm{C}-\mathrm{H}$ bonds, in particular the C2 or C3 positions in heteroarenes (scheme 2a). Metal catalyzed domino reactions constitute in this case an interesting alternative, as they give access to heterocycles functionalized at other positions. Our group reported several domino 
a) Selective direct functionalizations of heterocycles developed by our group

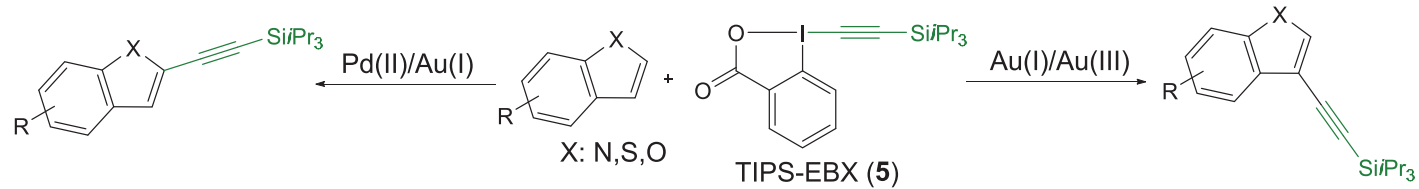

b) Domino reactions developed by our group

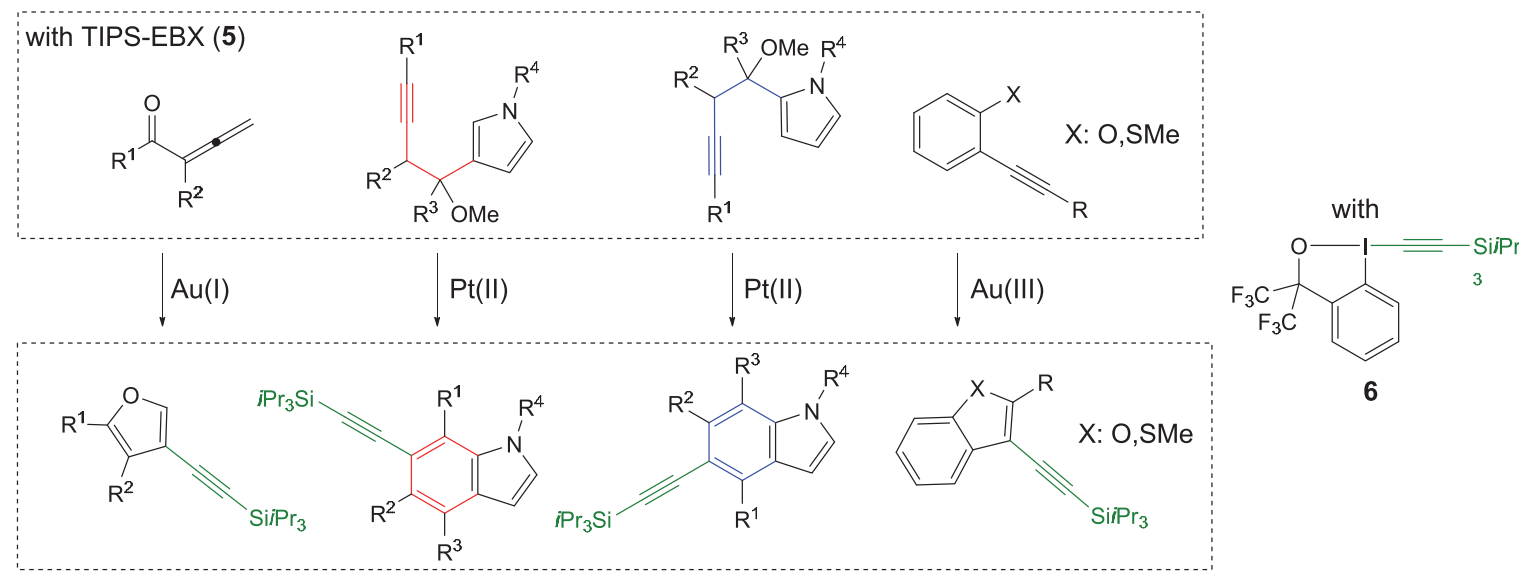

c) This work
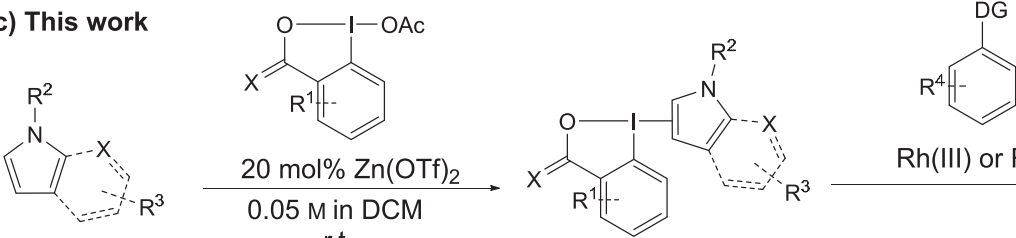

Indole- and Pyrrole-BX

33 bench-stable reagents

Scheme 2. a) and b) Previous work of the group on the synthesis of alkynylated heterocycles via C-H functionalization or domino processes. c) This work.

approaches for the synthesis of heterocycles alkynylated on the benzene ring (scheme 2b). C3-alkynylated furans were obtained starting from $\alpha$ allenyl ketones. ${ }^{[62]}$ A gold(III) catalyst was initially used for this transformation, but in situ formation of an active gold(I) catalyst was proposed later based on computational studies. ${ }^{[65]} \mathrm{C} 5$ - and C6- alkynylated indoles were built starting from alkylated pyrrole precursors: Starting from C3-alkylated pyrroles C6-alkynylated indoles were obtained, while C2alkylated pyrroles afforded C5-alkynylated indoles. ${ }^{[63]}$ Finally, several C3 alkynylated benzothiophenes and benzofurans were synthesized from aryl-thiols and phenols. ${ }^{[64]}$

Based on these results, our initial aim was to expand the scope of domino transformations to other hypervalent iodine reagents, in particular azidobenziodoxol(on)es (ABX). ${ }^{[66-68]}$ Our choice of ABX was justified by the large number of applications and chemical modifications related to azides, such as reduction to amines or cycloaddition with alkynes ${ }^{\left[{ }^{[6]}\right]}$ and the recent success reported with this reagent for azide transfer reactions. ${ }^{[70-78]}$ Best results in the domino cyclization-alkynylation reactions had been obtained with hexafluoroisopropanol derived reagent $\mathbf{6}$. Therefore the corresponding reagent 8 containing an azide was synthesized ${ }^{[66]}$ and the domino cyclization-azidation of pyrrole $\mathbf{7}$ was attempted under the conditions successful for alkynylation (the solvent was changed to solubilize the $A B X$ reagent 8 ). However, we did not obtain the desired azidated indole 9, but we observed the full conversion to a polar compound containing ${ }^{1} \mathrm{H}$ NMR signals corresponding to a 2-iodobenzoate ring and a substituted pyrrole, without modification of the alkyl substituent (Eq. 1). The same result was obtained in absence of the platinum catalyst.

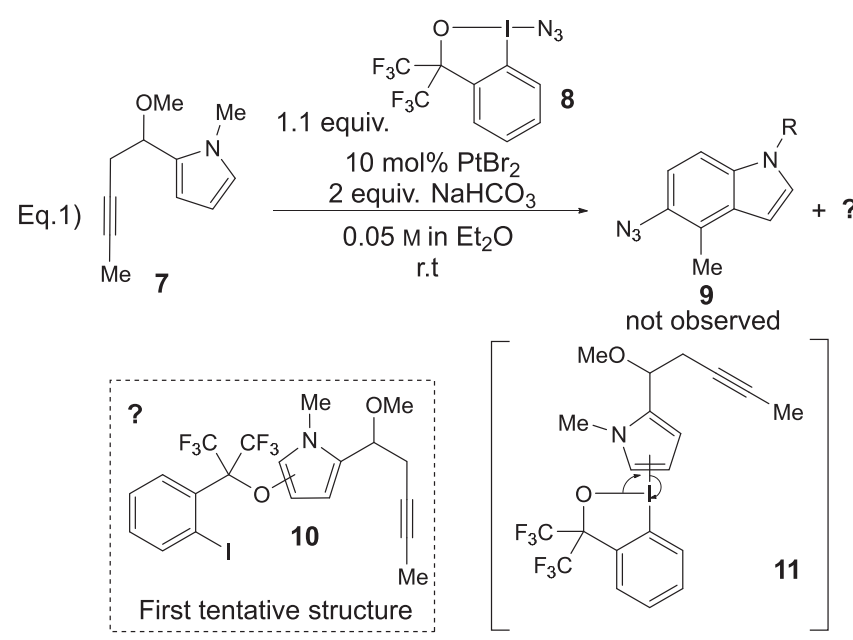

To explain the observed NMR spectra, we first hypothesized that a new C$\mathrm{O}$ bond had been formed between the alcoholate and the pyrrole ring to give heterocycle 10. Due to the good leaving group ability of the azide, nucleophilic attack of the pyrrole ring followed by re-aromatization and 
release of hydrazoic acid would give hypervalent iodine reagent 11. At this stage, we speculated that this intermediate would be unstable and undergo reductive elimination to give 10. Unfortunately, the new compound was unstable, and it was not possible to confirm its structure. As the new transformation did not involve the alkyne triple bond, we decided to study simple commercially available $N$-methyl pyrrole (12) and $\mathrm{N}$-methyl indole (14) as starting materials (Eq. 2) and 3)). For pyrrole 12, we again observed the formation of a 1:1 C2:C3-functionalized separable mixture of two highly polar regioisomers; these two compounds were stable and obtained in a combined excellent yield of $91 \%$ (Eq. 2)). In case of indole 14, a single C3-functionalized product was obtained in $25 \%$ yield (Eq. 3).

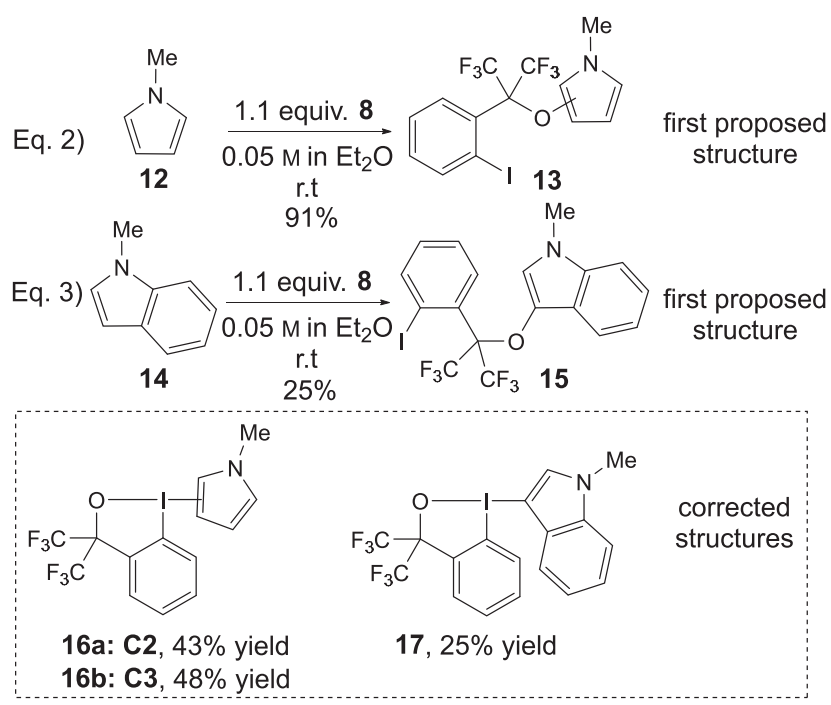

a) Expected ${ }^{1} \mathrm{H}$ and ${ }^{13} \mathrm{C}$ NMR shifts for proposed structures

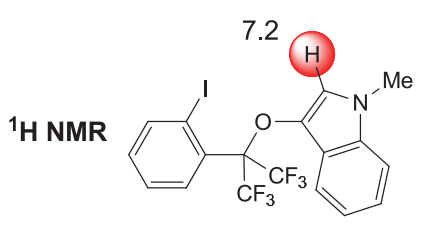

15

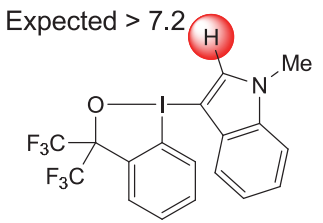

17
At this point, we still hypothesized that we had formed a new C-O bond with the heterocycle (structures 13 and 15). However, extensive NMR analysis performed on the product obtained from indole $\mathbf{1 4}$ were not in agreement with this assignment, and fitted better with structure 17 still containing a hypervalent iodine atom (figure 1). First, the expected proton and carbon chemical shifts around the iodine atom were estimated for both envisaged structure 15 and 17 based on the reported values for 1(1,1,1,3,3,3-hexafluoro-2-methoxypropan-2-yl)-2-iodobenzene, ${ }^{[79]}$ indoles bearing an oxygen substituent on the C3 position, ${ }^{[80,81]}$ hexafluoroisopropanol derived hypervalent iodine reagents ${ }^{[62]}$ and indole iodonium salts. ${ }^{[26]}$ The observed indole $\mathrm{C} 2{ }^{1} \mathrm{H}$ signal at $7.51 \mathrm{ppm}$ is in lower field than expected for a compound such as $\mathbf{1 5}$, but this fact alone was not sufficient to support the hypervalent structure. Hypervalent iodine compounds can usually be easily differentiated from the corresponding iodines via the ${ }^{13} \mathrm{C}$ chemical shift of the adjacent carbon, which appears in about 20-30 ppm in lower field. However, in the specific case of the alternative structures 15 and 17, the influence of the iodine atom and the indole core on the chemical shift are expected to compensate each other, leading in each case to two signals around 80-90 ppm and one signal at 110-120 ppm for the carbon atoms in proximity to the iodine atom (figure 1a). The observed values of $81.7,84.5$ and $112.2 \mathrm{ppm}$ are in better agreement with the hypervalent iodine structure, but the difference is not enough to be sure of the assignment. Fortunately, the positions of the aromatic signals in higher field is different for the two proposed structures: on the benzene ring for $\mathbf{1 5}$ and on the indole for $\mathbf{1 7}$.
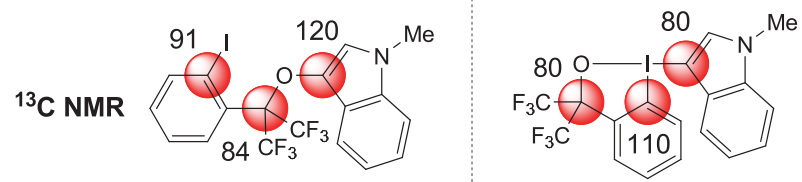

15 17

b) Measured chemical shifts and important HMBC correlations

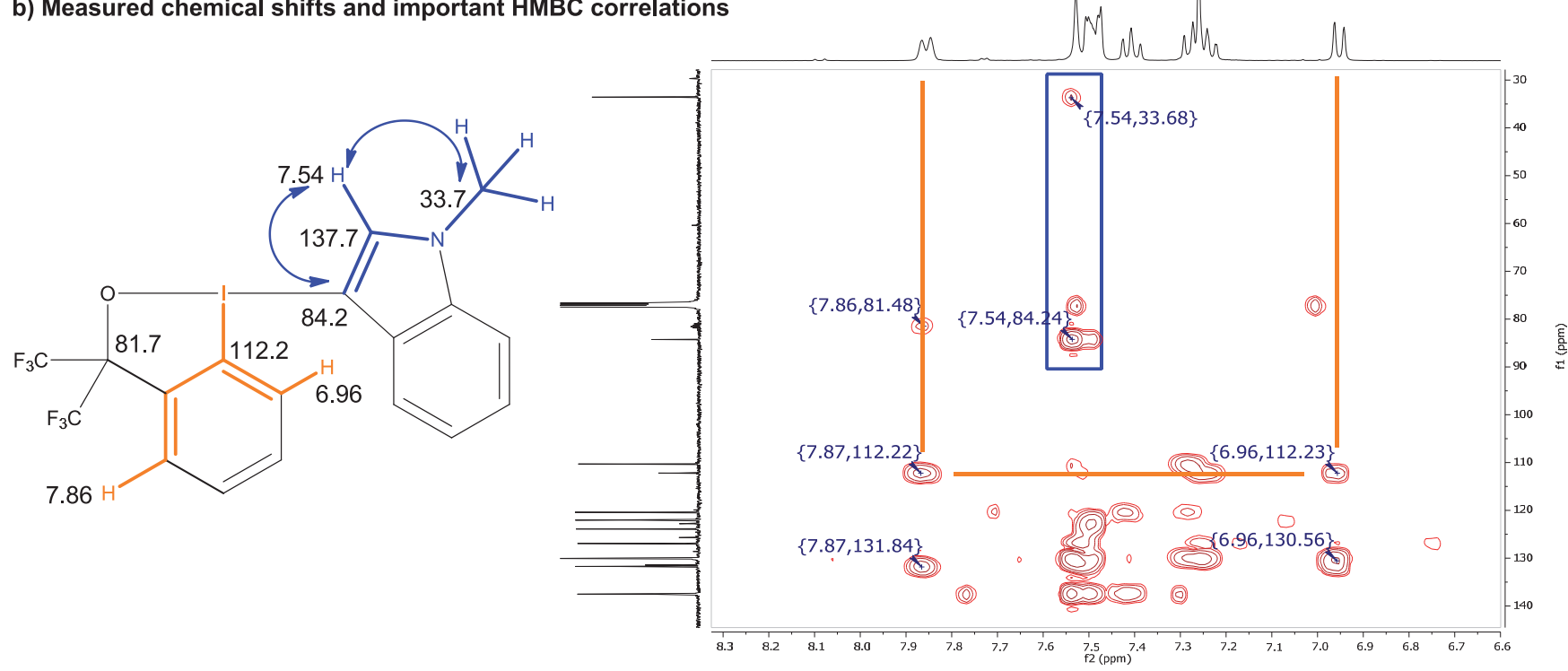

Figure 1. Structure assignment of $\mathbf{1 7}$ based on NMR analysis. All values are chemical shifts in ppm. 
Extensive 2-D NMR experiments allowed a full assignment of the signals ${ }^{[82]}$ and unambiguously showed that the signal at $112.2 \mathrm{ppm}$ was on the benzene ring and the one at $84.5 \mathrm{ppm}$ on the indole, supporting hypervalent structure 17. $\mathrm{HMBC}$ correlations between the arene $\mathrm{C}-\mathrm{H}$ signals at 6.96 and $7.86 \mathrm{ppm}$ and the quaternary carbon at $112.2 \mathrm{ppm}$, as well as between the $\mathrm{C} 2$ indole $\mathrm{C}-\mathrm{H}$ signal at $7.54 \mathrm{ppm}$ and the quaternary C3 carbon at $84.2 \mathrm{ppm}$ were especially important for the structure assignment (Figure 1b).

Establishing the hypervalent structure of the obtained products was an important step, as benziodoxole-based indole or pyrrole reagents had never been reported before. We therefore decided to further improve the synthesis of these new "Indole-BX" and "Pyrrole-BX" reagents in order to study their properties and potential synthetic applications (table 1). Indole reagent $\mathbf{1 7}$ could be obtained only in $25 \%$ yield using azidobenziodoxole reagent $\mathbf{8}$, (table 1 , entry 1 ). The influence of the leaving group on the iodine was first investigated. In fact, azido-substituted hypervalent iodine reagents are often unstable and toxic azide salts are generated during the reaction. We then decided to employ 1-acetoxy-1,3-dihydro-3,3bis(trifluoromethyl)-1,2-benziodoxole (18), a more stable and readily available reagent. ${ }^{[83]}$ However, no reaction was observed (table 1, entry 2). Lewis acids, in particular zinc(II) triflate, have been used by our group and others for the activation of benziodoxole reagents. ${ }^{[71,84]}$ In fact, when a catalytic amount of zinc(II) triflate was added, a promising $56 \%$ yield of 17 was obtained (table 1, entry 3). As hexafluoroisopropanol-derived hypervalent iodine reagents are expensive, we then tested 1-hydroxy-1,2benzodioxol-3 $-(1 H)$-one $(\mathbf{1 9})^{[85]}$ under these conditions, but the desired product 21 was not obtained (table 3, entry 4). In contrast, 36\% yield of 21 was isolated starting from acetoxy benziodoxolone $\mathbf{2 0}^{[86]}$ (table 1, entry 5). No product was obtained in absence of zinc(II) triflate (table 1, entry 6).

Table 1. Optimization of the synthesis of IndoleBX 17 and 21.

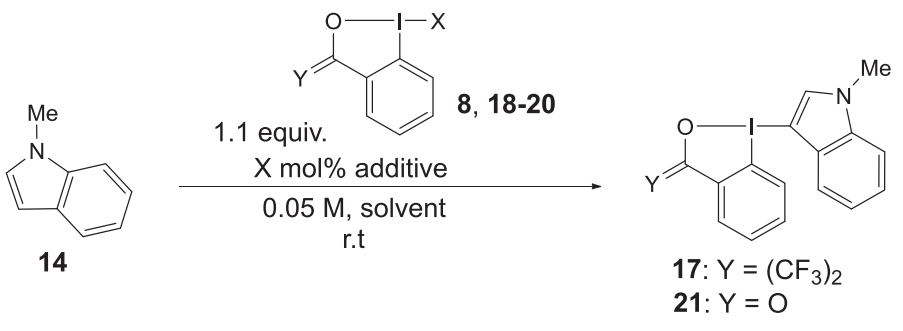

\begin{tabular}{|c|c|c|c|c|c|c|}
\hline Entry & Reagent & $Y$ & $x$ & Solvent (M) & Additive (mol\%) & Yield $\%^{\mathrm{a}}$ \\
\hline 1 & 8 & $\left(\mathrm{CF}_{3}\right)_{2}$ & $\mathrm{~N}_{3}$ & $\mathrm{Et}_{2} \mathrm{O}(0.05)$ & - & $25 \%$ \\
\hline 2 & 18 & $\left(\mathrm{CF}_{3}\right)_{2}$ & OAC & $\mathrm{Et}_{2} \mathrm{O}(0.05)$ & & -b \\
\hline 3 & 18 & $\left(\mathrm{CF}_{3}\right)_{2}$ & OAc & $\mathrm{Et}_{2} \mathrm{O}(0.05)$ & $\mathrm{Zn}(\mathrm{OTf})_{2}(10)$ & $56 \%$ \\
\hline 4 & 19 & $\mathrm{o}$ & $\mathrm{OH}$ & $\mathrm{Et}_{2} \mathrm{O}(0.05)$ & $\mathrm{Zn}(\mathrm{OTf})_{2}(10)$ & $-\mathrm{b}$ \\
\hline 5 & 20 & $\mathrm{o}$ & OAC & $\mathrm{Et}_{2} \mathrm{O}(0.05)$ & $\mathrm{Zn}(\mathrm{OTf})_{2}(10)$ & $36 \%$ \\
\hline 6 & 20 & o & OAc & $\mathrm{Et}_{2} \mathrm{O}(0.05)$ & - & -b \\
\hline 7 & 20 & 0 & OAC & $\mathrm{Et}_{2} \mathrm{O}(0.05)$ & TMSOTf (10) & $16 \%$ \\
\hline 8 & 20 & 0 & OAc & $\mathrm{Et}_{2} \mathrm{O}(0.05)$ & $\mathrm{Cu}(\mathrm{OTf})_{2}(10)$ & $36 \%^{\mathrm{c}}$ \\
\hline 9 & 20 & 0 & OAc & $\mathrm{Et}_{2} \mathrm{O}(0.05)$ & $\operatorname{AgNTf}_{2}(20)$ & $-c$ \\
\hline 10 & 20 & 0 & OAc & $\mathrm{Et}_{2} \mathrm{O}(0.05)$ & $\operatorname{TBAF}(20)$ & $-c$ \\
\hline 11 & 20 & 0 & OAc & $\mathrm{Et}_{2} \mathrm{O}(0.05)$ & $\operatorname{AgF}(20)$ & $-c$ \\
\hline 12 & 20 & 0 & OAc & THF (0.05) & $\mathrm{Zn}(\mathrm{OTf})_{2}(10)$ & \\
\hline 13 & 20 & 0 & OAc & DCM (0.05) & $\mathrm{Zn}(\mathrm{OTf})_{2}(10)$ & full $^{d}$ \\
\hline 14 & 20 & 0 & $O A c$ & DCM $(0.05)$ & $\mathrm{Zn}(\mathrm{OTf})_{2}(20)$ & $97 \%$ \\
\hline
\end{tabular}

a) Substrate $14(0.100 \mathrm{mmol})$, reagents $8,18-20(0.110 \mathrm{mmol})$, additive $(10-20 \mathrm{~mol} \%)$, and solvent $(0.05 \mathrm{M})$ at $25^{\circ} \mathrm{C}$. Isolated yield after flash chromatography is given. b) No conversion: starting materials recovered. c) Complete decomposition of the hypervalent iodine reagents. d) 2.2 equiv. of 20 were required.

Other Lewis acid could be also used in this transformation, but with inferior results: TMSOTf gave the product in $16 \%$ yield only (table 1, entry 7 ); In the case of $\mathrm{Cu}(\mathrm{II})$ triflate, although a similar yield was obtained, significant decomposition of products $\mathbf{2 1}$ into $\mathrm{N}$-methyl-3-iodo-indole was observed (table 1, entry 8 ). No product could be isolated with a silver(I) catalyst (table 1, entry 9). As fluoride-substituted benziodoxole reagents have been successfully used as precursors in previous works, ${ }^{[87]}$ fluoride sources were then examined, but without success (table 1, entries 10 and 11). Finally, we decided to screen other solvents, as $\mathrm{Zn}(\mathrm{OTf})_{2}$ was only scarcely soluble in $\mathrm{Et}_{2} \mathrm{O}$. When THF was used, no product was obtained probably due to the low solubility of benziodoxolone 20 in this solvent (table 1, entry 12). In DCM, full conversion was observed, but it required the use of two 


\section{HELVETICA}

equivalents of benziodoxolone $\mathbf{2 0}$ (table 2, entry 13). Full conversion and an excellent $97 \%$ yield could be obtained by raising the amount of zinc(II) triflate to $20 \mathrm{~mol} \%$ (table 1, entry 14). The developed protocol based on the catalytic use of a relatively mild Lewis acid is noteworthy, as most syntheses of alkynyl, vinyl or aryl benziodoxolone reagents usually require a stoichiometric amount of strong Lewis or Brønsted acid. ${ }^{[32,88,89]}$ In fact, these reported procedures were not successful for the synthesis of IndoleBX 21, as they led to complete decomposition of indole $\mathbf{1 4}$. Furthermore, IndoleBX $\mathbf{2 1}$ displayed excellent thermal stability properties when compared to indole iodonium salts. A DSC measurement showed that significant decomposition started only at $151{ }^{\circ} \mathrm{C}$, with a peak maximum at $183^{\circ} \mathrm{C}$ (figure 2). An exothermic decomposition $(283 \mathrm{~J} / \mathrm{g}$ ) was observed, with a peak height of $17.3 \mathrm{~mW}$ and a peak width of $3.7^{\circ} \mathrm{C}{ }^{[90]}$

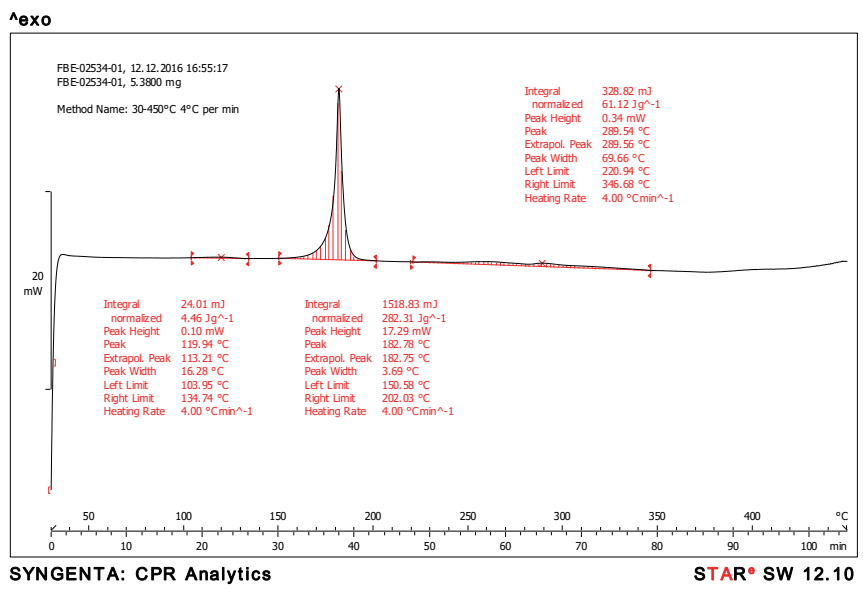

Figure 2. DSC measurement of IndoleBX 21.

When the reaction was scaled up to $0.2 \mathrm{mmol}$, Indole-BX $\mathbf{2 1}$ was obtained in $87 \%$ yield (eq. 4)). No decrease in yield was observed when scaling up to 1-10 mmol (gram scale). The developed protocol could also be applied to benziodoxole reagents. The yield of hexafluoropropanol-derived benziodoxole 17 was also improved under these reaction conditions. The dimethyl reagent $\mathbf{2 3}$ was also synthesized in $\mathbf{5 1 \%}$ yield. The developed reaction conditions could not be used for $\mathrm{N}$-unprotected indoles. Nevertheless, the use of $\mathrm{N}$-TBS protected indole (24) afforded a mixture of unreacted starting material, $\mathrm{N}$-TBS protected reagent in low yield and a small amount of $\mathrm{NH}$ free indole reagent $\mathbf{2 5}$. When $20 \mathrm{~mol} \%$ of Sc(III) triflate was used instead, $\mathrm{NH}$ free reagent $\mathbf{2 5}$ could be obtained cleanly in $\mathbf{7 8 \%}$ yield (eq. 5). Reagent 25 showed crystalline properties, unlike other reagents that presented a resin-like amorphous character. It was possible to obtain high quality crystal for X-ray analysis, which finally confirmed the hypervalent structure of the reagents (figure 3 ).
Eq. 4)

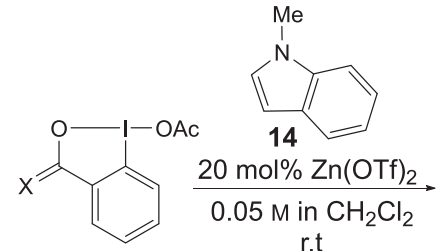

1.1 equiv.

18: $\mathrm{X}=\left(\mathrm{CF}_{3}\right)_{2}$

20: $X=O$

22: $\mathrm{X}=\left(\mathrm{CH}_{3}\right)_{2}$

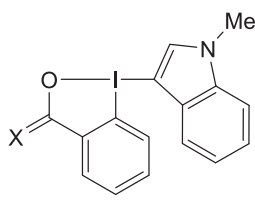

17: $\mathrm{X}=\left(\mathrm{CF}_{3}\right)_{2}, 56 \%$

21: $X=0,87 \%$

23: $\mathrm{X}=\left(\mathrm{CH}_{3}\right)_{2}, 51 \%$
Eq. 5)

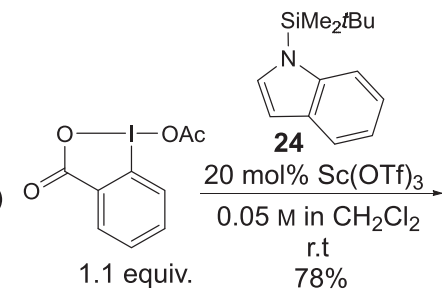

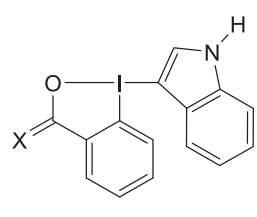

25

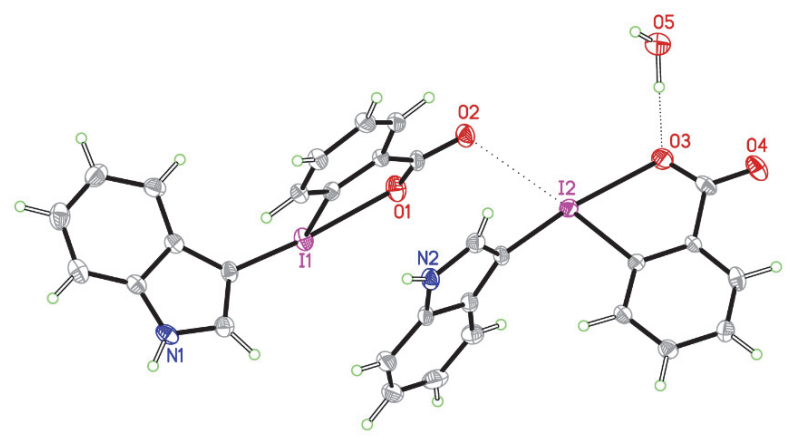

Figure 3. ORTEP drawing of reagent $(\mathbf{2 5}) \cdot \mathrm{H}_{2} \mathrm{O}$

The method proved to be reliable also in the synthesis of reagents bearing different functional groups on the indole ring (figure 4). In case of electrondonating functional groups such as methyl on the C2 position or methoxy on the C5 position, the respective reagents $\mathbf{2 6}$ and $\mathbf{2 7}$ were obtained in excellent yields. Halogen substituents were also tolerated under the reaction conditions: fluorine, chlorine and iodine containing reagents 2830 were synthesized in $62-85 \%$ yield. With a pinacol boronate in C5 position, reagent $\mathbf{3 1}$ was obtained in moderate yield. The tolerance towards both halogen and boron substituents sets the stage for further functionalization via cross-coupling reactions. All these reagents could be synthesized on $1 \mathrm{mmol}$ scale without the need for any re-optimization. We then investigated variation of the nitrogen substituent. Different alkyl chains were tolerated. While the $\mathrm{N}$-phenyl-propyl reagent 32 and the $\mathrm{N}$-3butenyl reagent $\mathbf{3 3}$ were isolated in very good yields, the $N$-triisopropylethoxy $\mathbf{3 4}$ suffered from a slight decrease in yield. 
<smiles>Cc1c(I2COC2=O)c2ccccc2n1C</smiles>

26

91\% yield<smiles>Cn1cc(I2COC(=O)c3ccccc32)c2cc(Cl)ccc21</smiles>

29

$62 \%$ yield

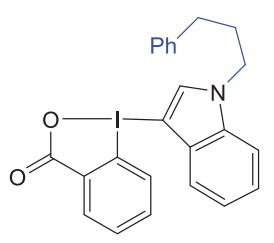

32

$88 \%$ yield

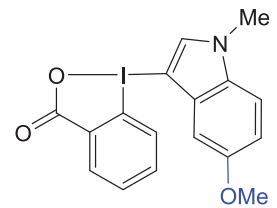

27

$87 \%$ yield

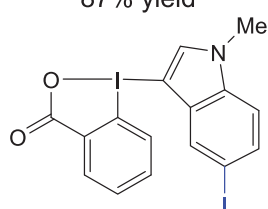

30

$76 \%$ yield

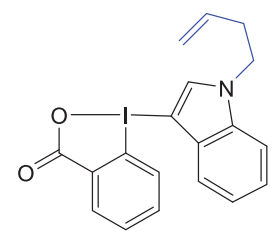

33

$86 \%$ yield

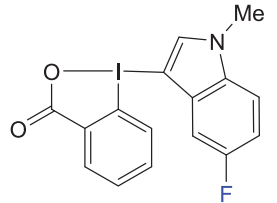

28 $85 \%$ yield

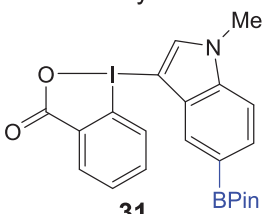

31 $54 \%$ yield

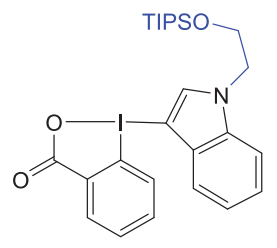

34

$60 \%$ yield
Figure 4. Scope of IndoleBXs: variation of the functional groups on indole. Reaction conditions: $1.00 \mathrm{mmol}$ heterocycle, $1.10 \mathrm{mmol} 20,0.200 \mathrm{mmol} \mathrm{Zn}(\mathrm{OTf})_{2}, 0.05 \mathrm{M}$ in $\mathrm{CH}_{2} \mathrm{Cl}_{2}$, r.t., open air. Isolated yields.

The synthesis of PyrroleBX reagents was then investigated (figure 5). When $\mathrm{N}$-methyl or $\mathrm{N}$-benzyl pyrroles were employed as starting materials, separable regioisomeric $\mathrm{C} 2: \mathrm{C} 3$ mixtures of reagents $\mathbf{3 5}$ and $\mathbf{3 6}$ were obtained in high yield. In the case of $\mathbf{3 6}$, the steric hindrance of the $\mathrm{N}$ substituent led to the formation of the $\mathrm{C} 3$ isomer as the major one. The importance of steric effects was confirmed by the use of a N-TBS group which led to the formation of C3-substituted reagent $\mathbf{3 7}$ exclusively by using $\mathrm{Sc}(\mathrm{OTf})_{3}$ as catalyst. As in the case of indole reagent $\mathbf{2 5}$, complete deprotection of the silyl group occurred. As for reagent $\mathbf{2 5}$, reagent $\mathbf{3 7}$ showed good water solubility and crystalline properties. It was possible to obtain an X-ray analysis confirming the substitution at the C3 position (figure 6).<smiles>Cn1cccc1[IH]OC(=O)c1ccccc1</smiles>

35

$\mathrm{C} 2: \mathrm{C}^{35}=1: 1$

$95 \%$ yield<smiles></smiles>

36
C2: $: 3$ = $1: 3$

$86 \%$ yield<smiles>[M]OC=CI1OC(C(F)(F)F)(C(F)(F)F)c2ccccc21</smiles>

16

$\mathrm{C} 2: \mathrm{C} 3=1: 1$

$90 \%$ yield<smiles>CCNC</smiles><smiles>[Y19]NCC</smiles>

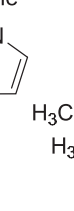

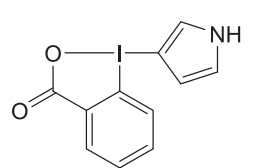

37 $72 \%$ yield $^{[a]}$<smiles>Cn1cccc1I1C=CC=C1C(C)(C)O</smiles>

38

$$
\text { C2:C3 = 1:9 }
$$

$91 \%$ yield

Figure 5. Scope of PyrroleBX reagents. Reaction conditions: $1.00 \mathrm{mmol}$ heterocycle, $1.10 \mathrm{mmol} \mathbf{1 8}, \mathbf{2 0}$ or $\mathbf{2 2}, 0.200 \mathrm{mmol} \mathrm{Zn}(\mathrm{OTf})_{2}, 0.05 \mathrm{M} \mathrm{in} \mathrm{CH}_{2} \mathrm{Cl}_{2}, \mathrm{RT}$, open air. Isolated yields. [a] $\mathrm{Sc}(\mathrm{OTf})_{3}$ was used starting from $N$-TBS-pyrrole (TBS = tert-butyldimethylsilyl).

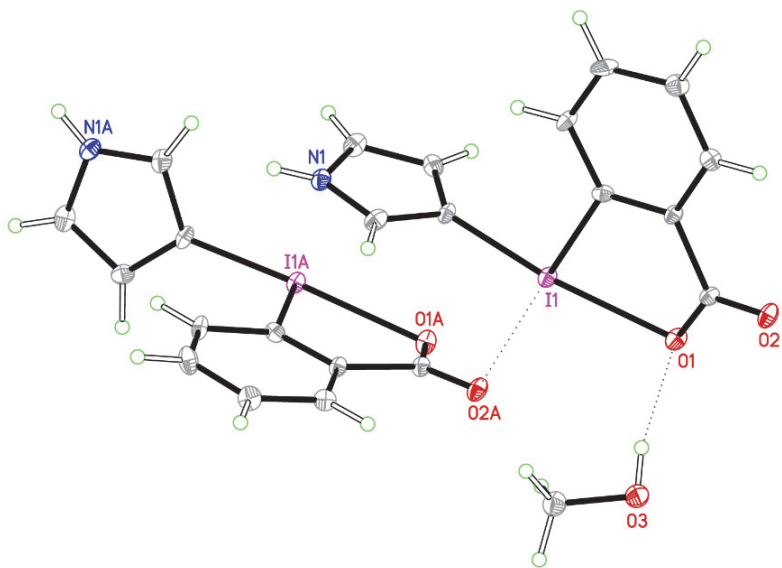

Figure 6. ORTEP drawing of reagent 37.MeOH

We then investigated if the nature of the reagent backbone could influence the $\mathrm{C2}: \mathrm{C3}$ ratio for PyrroleBX reagents. When applying the optimized conditions to the synthesis of the hexafluorodimethyl-scaffold, reagent 16 was again formed as a 1:1 mixture of isomers. However, when we performed the reaction with dimethyl precursor $\mathbf{2 2}$, benziodoxole $\mathbf{3 8}$ was obtained as an inseparable 1:9 mixture of $\mathrm{C} 2: \mathrm{C} 3$ regioisomers. At this point, the reasons for the higher regioselectivity observed with this reagent are not clear. One possible explanation would be lower electrophilicity at the iodine center, which would lead to steric effects dominating about the higher nucleophilicity of the $C 2$ position.

In order to confirm this hypothesis, we decided to investigate the influence of electron-donating and electron-withdrawing groups when installed on the arene ring of the reagents (figure 7). ${ }^{[82]}$ IndoleBX 39 could be obtained in 56\% yield. The corresponding PyrroleBX reagent $\mathbf{4 0}$ was formed as a 1:2 C2:C3 mixture of regioisomers. The ratio shifted slightly towards the less electron-rich and less encumbered C3 position when compared with reagent 35. A fluorine in meta position to the iodine did not influence massively the outcome of the reaction, as $\mathbf{4 1}$ was obtained as a 1:3 ratio of C2:C3 isomers. Finally, with a strong electron-withdrawing nitro group in para position to the iodine, the ratio reversed in favor of the $\mathrm{C} 2$ regioisomer. The desired reagent $\mathbf{4 2}$ was obtained with a 4:1 C2:C3 ratio in excellent yield. In this case, the iodine atom was expected to be highly electrophilic and electronic control would become more important than sterics.

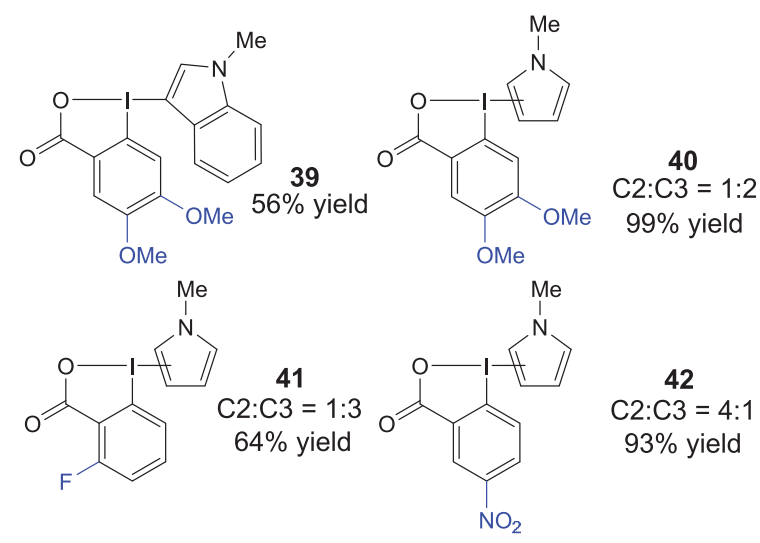

Figure 7. Scope of IndoleBXs and PyrroleBXs: modification of the benzene ring Reaction conditions: $0.20 \mathrm{mmol}$ heterocycle, $0.220 \mathrm{mmol}$ acetoxybenziodoxolone, $0.040 \mathrm{mmol} \mathrm{Zn}(\mathrm{OTf})_{2}, 0.05 \mathrm{M}$ in $\mathrm{CH}_{2} \mathrm{Cl}_{2}, \mathrm{RT}$, open air. Isolated yields. 


\section{HELVETICA}

Finally, preliminary investigations were done for the synthesis of reagents bearing other heterocycles than indole or pyrrole (figure 8). Azaindolebased reagent $\mathbf{4 3}$ was obtained in moderate yield and high C3 regioselectivity. In case of CarbazoleBX 44, the yield was moderate, but the regioselectivity very high, as the iodine was bound exclusively to the carbon in para position to the nitrogen. ThiopheneBX 45 and DimethylFuranBX 46 were also synthesized in low to moderate yield. In this case, the corresponding iodonium salts are already known and have been applied in catalytic transformations. ${ }^{[91-96]}$
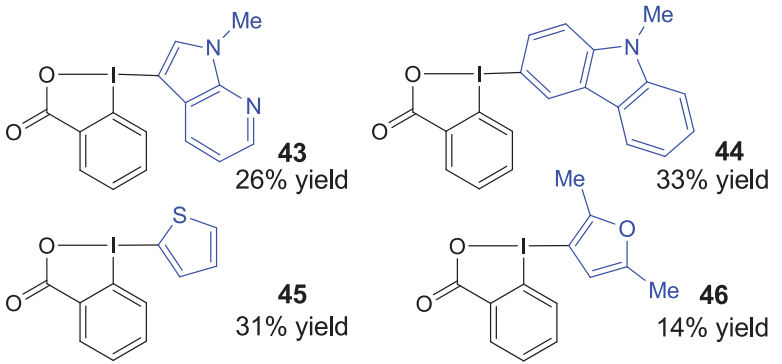

Figure 8. Scope of other HeterocyclicBXs. Reaction conditions: $1.00 \mathrm{mmo}$ heterocycle, $1.10 \mathrm{mmol} 20,0.200 \mathrm{mmol} \mathrm{Zn}(\mathrm{OTf})_{2}, 0.05 \mathrm{M}$ in $\mathrm{CH}_{2} \mathrm{Cl}_{2}$, RT, open air. Isolated yields.

At this point only a highly speculative mechanism can be proposed for the formation of the IndoleBX reagents (scheme 3a). Activation of benziodoxole $\mathbf{2 0}$ by zinc(II) triflate would first give highly electrophilic iodonium intermediate I. $^{[84]}$ Nucleophilic attack of $N$-methyl indole (14) on the iodine center will then give intermediate II. The acetate ligand could then act as an internal base to re-aromatize the indole ring, leading to the formation of acetic acid and closing of the benziodoxole ring. Activation of the acetate as a leaving group by zinc(II) triflate followed by the acetate acting as an external base could also be considered. In previous mechanism studies involving the activation of heterocycles with hypervalent iodine reagents, the formation a charge-transfer (CT) complex between the hypervalent iodine reagent and the heterocycle had been proposed. ${ }^{[97,98]}$ Single electron transfer would then give a radical cation intermediate that would recombine with the formed iodine radical. This mechanism appeared less probable to rationalize the formation of IndoleBX 21, based on the fact that (1) Moriarty and co-workers had observed a fast fragmentation of the radical formed from indole iodonium salt to give 3-iodo-indole and the benzene radical; ${ }^{[39]}$ No 3-iodo indole was observed in our work; And (2) the high selectivity observed for the C3 position is difficult to rationalize for a radical pathway. Formation of a C2bond iodine intermediate followed by migration can also be excluded, as the C2-enriched deuterium reagent $\mathbf{4 8}$ was obtained without the loss of any deuterium enrichment (scheme $3 b$ ). a) Speculative mechanism
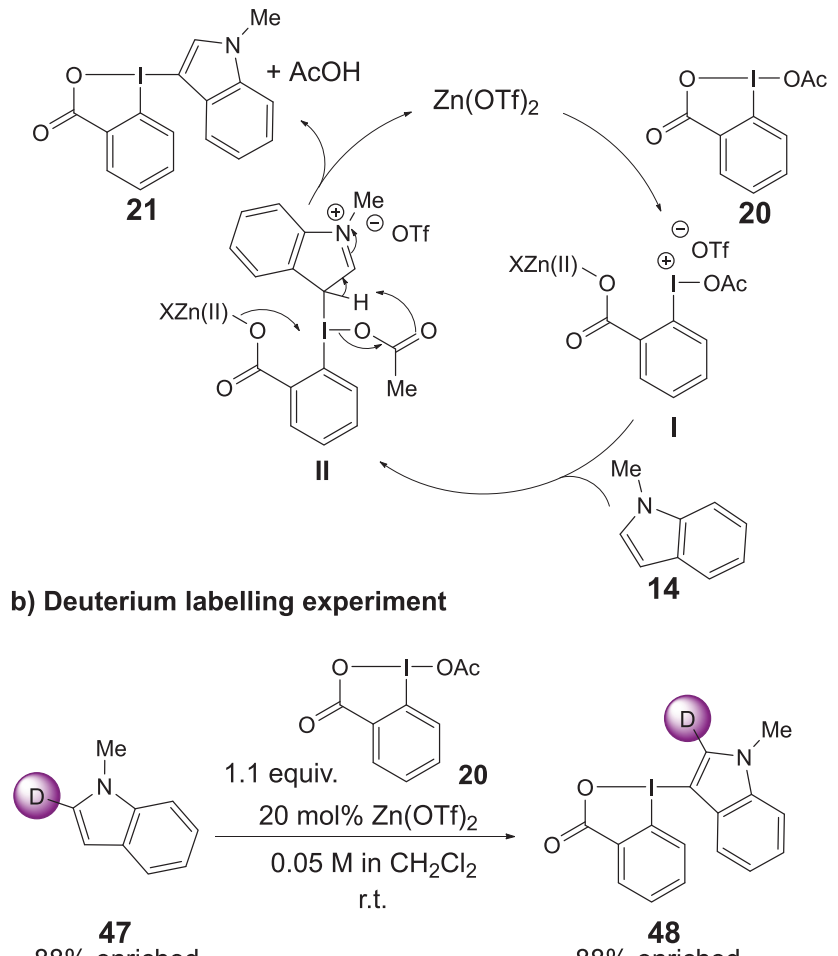

$88 \%$ enriched

Scheme 3. Speculative mechanism and deuterium labelling experiment. For simplification, the exact geometry at the iodine center including the lone pairs is not drawn.

With a broad range of new IndoleBX and PyrroleBX in hand, we started investigating possible applications. As previously stated in the introduction, arylated pyrroles and indoles constitute a class of versatile molecules, but their synthesis based on arene $\mathrm{C}-\mathrm{H}$ functionalization has not been realized so far. In particular, (hetero)-arylated aryl-pyridines such as $\mathbf{5 2}$ (scheme 4) would be useful as key intermediates for the synthesis of optoelectronic materials. ${ }^{[99]}$ However, no synthesis via direct ortho $\mathrm{C}-\mathrm{H}$ functionalization has ever been reported, despite the tremendous recent progress in this area. ${ }^{[100]}$ We first investigated if the indolation of pyridine 49 would be possible using state-of-the-art C-H functionalization methods (scheme 4). Reported catalytic systems based on palladium(0) (A, B $)^{[101,102]}$ or palladium(II) $(\text { C, D })^{[59,103]}$ precursors in combination with iodo- and bromo-indoles, did not lead to the formation of the desired product $\mathbf{5 2}$. Using a palladium(II)/copper(I) mixed system was also unsuccessful (E). ${ }^{[102]}$ Oxidative methods reported for the direct $\mathrm{C}-\mathrm{H}$ coupling of indoles were then examined. However, neither palladium $(\mathbf{F}, \mathbf{G})^{[18,104]}$ or rhodium $(\mathbf{H})^{[105]}$ based methods, nor direct oxidation with hypervalent iodine reagents activated by Lewis acids (I) ${ }^{[22]}$ worked efficiently. All the reported catalytic methods were screened at different temperatures, starting from $50{ }^{\circ} \mathrm{C}$ and increasing up to a maximum of $140{ }^{\circ} \mathrm{C}$, in order to take into account different reaction kinetics. 
<smiles>c1ccc(-c2ccccn2)cc1</smiles><smiles>[X]c1cn(C)c2ccccc12</smiles>

49

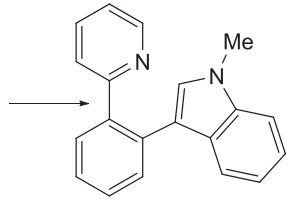

52

\begin{tabular}{|c|c|c|}
\hline \multicolumn{3}{|c|}{$X=B r, I(51,52)$} \\
\hline $\begin{array}{c}5 \mathrm{~mol}^{\%} \mathrm{Pd}(\mathrm{dba})_{2} \\
5 \mathrm{~mol}^{\circ} \mathrm{PPh}_{3} \\
0.2 \mathrm{~m} \text { in toluene }\end{array}$ & $\begin{array}{c}2.5 \mathrm{~mol} \% \mathrm{Pd}\left(\mathrm{PPh}_{3}\right)_{3} \\
1.0 \text { equiv. } \mathrm{Na}_{2} \mathrm{CO}_{3} \\
0.1 \mathrm{~m} \text { in } \mathrm{DMF}\end{array}$ & $\begin{array}{c}20 \mathrm{~mol} \% \mathrm{Pd}(\mathrm{OAc})_{2} \\
20 \mathrm{~mol} \% \mathrm{P}(\mathrm{o}-\mathrm{Tol})_{3} \\
3.0 \text { equiv. TEA } \\
0.2 \mathrm{~m} \text { in toluene }\end{array}$ \\
\hline A & B & C \\
\hline \multicolumn{2}{|c|}{$\begin{array}{c}5 \mathrm{~mol} \% \mathrm{PdCl}_{2} \\
5 \mathrm{~mol} \% \text { XanthPhos } \\
3.0 \text { equiv. TEA } \\
0.2 \mathrm{M} \text { in dioxane } \\
\text { D }\end{array}$} & $\begin{array}{l}\% \mathrm{PdCl}_{2} \mathrm{PPh}_{3} \\
\text { mol\% Cul } \\
\text { equiv. TEA } \\
\text { M in DMF } \\
\quad \mathbf{E}\end{array}$ \\
\hline \multicolumn{3}{|c|}{$X=H(14)$} \\
\hline 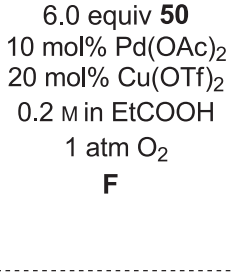 & $\begin{array}{c}5 \text { mol\% } \mathrm{Pd}(\mathrm{TFA})_{2} \\
3.0 \text { equiv. } \mathrm{Cu}(\mathrm{OAc})_{2} \\
6.0 \text { equiv. } \mathrm{PivOH} \\
\text { neat, } 120{ }^{\circ} \mathrm{C} \\
\text { G } \\
\text { TMSBr } \\
\text { PIDA, HFIP } \\
\text { I }\end{array}$ & $\begin{array}{c}2.5 \mathrm{~mol} \%\left[\mathrm{Rh}\left(\mathrm{Cp}^{*} \mathrm{Cl}_{2}\right)\right]_{2} \\
20 \text { mol\% } \mathrm{CsOPiv} \\
2.2 \text { equiv. } \mathrm{Cu}(\mathrm{OAc})_{2} \\
50 \text { mol\% } \mathrm{PivOH} \\
2.0 \text { equiv. } \mathrm{C}_{6} \mathrm{Br}_{6} \\
0.33 \text { min } 2-\mathrm{Cl}-p-x y l e n e \\
140^{\circ} \mathrm{C} \\
\mathrm{H}\end{array}$ \\
\hline
\end{tabular}

Scheme 4. Attempted synthesis of 2-indolyl pyridine $\mathbf{5 2}$ using reported $\mathrm{C}-\mathrm{H}$ functionalization methods.

We then turned to the use of the new Indole-BX reagent 21. Although no product could be obtained using reported palladium-catalyzed protocols (A-E, scheme 4), 52 was obtained in 55\% yield when using the mild conditions developed by $\mathrm{Li}$ and coworkers for the rhodium-catalyzed alkynylation of arenes with EBX reagents (Eq. 6)). ${ }^{[52]}$ The product was obtained as a single C3 regioisomer with complete chemoselectivity, as the benzoate group was not transferred on the aryl-pyridine. This is noteworthy, as controlling the selectivity of aryl transfer from iodonium salts is generally challenging. ${ }^{[106]}$ Furthermore, transfer of the benzoic acid is usually observed in the reaction of aryl benziodoxolones with nucleophiles. ${ }^{[89]}$ Under these conditions, no product was obtained with either iodo- or bromo- indoles 50 and 51. Indolyl benzyl iodonium salt $\mathbf{5 3}^{[35]}$ was also not successful.

Eq. 6)

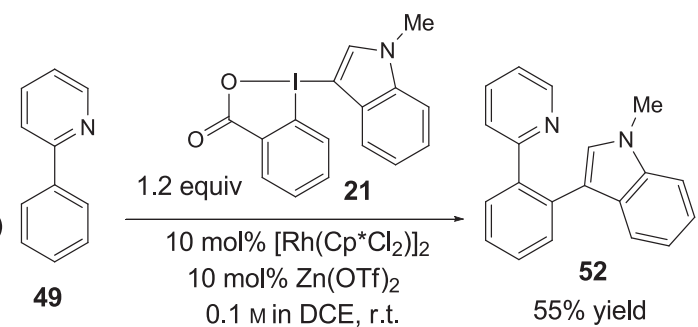

not successful with:

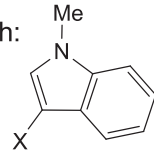

$50, \mathrm{X}=\mathrm{Br}$

51, $X=1$

53, $\mathrm{X}=\mathrm{IPhBF}_{4}$

Based on this promising result (table 2, entry 1 ), we started to optimize the transformation. First, control experiments showed that no reaction occurred with Lewis acids only (table 2, entry 2), even using the conditions specifically developed by Kita and coworkers for the activation of hypervalent iodine reagents (TMSBr in HFIP, table 2, entry 3). ${ }^{[92]}$ Several solvents were then screened (table 2, entries 4-7). In DCM, a lower yield was obtained (table 2, entry 4) and no product was observed in methanol or toluene (table 2, entries 5 and 6). In DMF a good 66\% yield of $\mathbf{5 2}$ was obtained, but only upon heating at $110^{\circ} \mathrm{C}$ (table 2 , entry 7 ).

Table 2. Optimization of the C-H indolation of pyridine $\mathbf{5 0 .}$

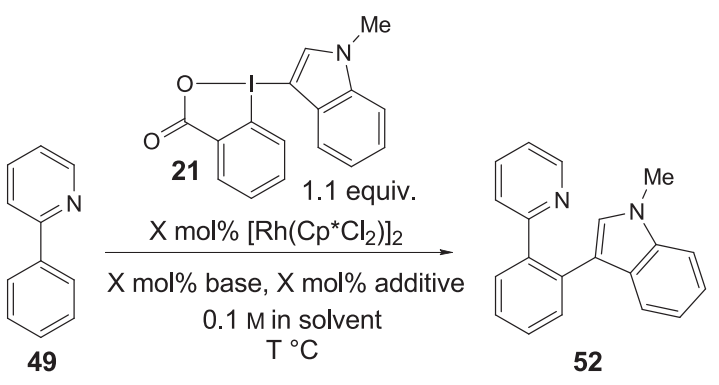

\begin{tabular}{|c|c|c|c|c|c|c|}
\hline Entry & Solvent ( $M$ ) & Base (mol\%) & Additive (mol\%) & Rh (mol\%) & $\mathbf{T}\left({ }^{\circ} \mathrm{C}\right)$ & Yield \% ${ }^{a}$ \\
\hline 1 & DCE & - & $\mathrm{Zn}(\mathrm{OTf})_{2}(10)$ & {$\left[\mathrm{Rh}\left(\mathrm{Cp}^{*} \mathrm{Cl}_{2}\right)_{2}\right](5)$} & RT & $55 \%$ \\
\hline 2 & DCE & - & $\mathrm{Zn}(\mathrm{OTf})_{2}(10)$ & - & RT & - \\
\hline 3 & HFIP & - & $\mathrm{TMSBr}$ & - & RT & - \\
\hline 4 & DCM & - & $\mathrm{Zn}(\mathrm{OTf})_{2}(10)$ & {$\left[\mathrm{Rh}\left(\mathrm{Cp}^{*} \mathrm{Cl}_{2}\right)_{2}\right](5)$} & RT. & $25 \%$ \\
\hline 5 & $\mathrm{MeOH}$ & - & $\mathrm{Zn}(\mathrm{OTf})_{2}(10)$ & {$\left[\mathrm{Rh}\left(\mathrm{Cp}^{*} \mathrm{Cl}_{2}\right)_{2}\right](5)$} & RT & - \\
\hline 6 & Toluene & - & $\mathrm{Zn}(\mathrm{OTf})_{2}(10)$ & {$\left[\mathrm{Rh}\left(\mathrm{Cp}^{*} \mathrm{Cl}_{2}\right)_{2}\right](5)$} & RT & - \\
\hline 7 & DMF & - & $\mathrm{Zn}(\mathrm{OTf})_{2}(10)$ & {$\left[\mathrm{Rh}\left(\mathrm{Cp}^{*} \mathrm{Cl}_{2}\right)_{2}\right](5)$} & 110 & $66 \%$ \\
\hline 8 & DCE & $\mathrm{K}_{2} \mathrm{CO}_{3}(10)$ & - & {$\left[\mathrm{Rh}\left(\mathrm{Cp}^{*} \mathrm{Cl}_{2}\right)_{2}\right](5)$} & RT & $28 \%$ \\
\hline
\end{tabular}




\begin{tabular}{|c|c|c|c|c|c|c|}
\hline 9 & DCE & KOAC (10) & - & {$\left[\mathrm{Rh}\left(\mathrm{Cp}^{*} \mathrm{Cl}_{2}\right)_{2}\right](5)$} & RT & $37 \%$ \\
\hline 10 & DCE & KOPiv & & {$\left[\mathrm{Rh}\left(\mathrm{Cp}^{*} \mathrm{Cl}_{2}\right)_{2}\right](5)$} & RT & $49 \%$ \\
\hline 11 & DCE & $\mathrm{NaOAc}(10)$ & - & {$\left[\mathrm{Rh}\left(\mathrm{Cp}^{*} \mathrm{Cl}_{2}\right)_{2}\right](5)$} & RT & $69 \%$ \\
\hline 12 & DCE & NaOPiv (10) & - & {$\left[\mathrm{Rh}\left(\mathrm{Cp}^{*} \mathrm{Cl}_{2}\right)_{2}\right](5)$} & RT & $72 \%$ \\
\hline 13 & DCE & - & $\operatorname{AgNTf}_{2}(10)$ & {$\left[\mathrm{Rh}\left(\mathrm{Cp}^{*} \mathrm{Cl}_{2}\right)_{2}\right](5)$} & RT & - $^{b}$ \\
\hline 14 & DCE & & $\mathrm{AgSbF}_{6}(10)$ & {$\left[\mathrm{Rh}\left(\mathrm{Cp}^{*} \mathrm{Cl}_{2}\right)_{2}\right](5)$} & RT & $17 \%$ \\
\hline 15 & DCE & NaOPiv (10) & $\mathrm{AgSbF}_{6}(10)$ & {$\left[\mathrm{Rh}\left(\mathrm{Cp}^{*} \mathrm{Cl}_{2}\right)_{2}\right](5)$} & RT & $0 \%$ \\
\hline 16 & DCE & NaOPiv (10) & $\mathrm{AgSbF}_{6}(10)$ & {$\left[\mathrm{Rh}\left(\mathrm{Cp}^{*} \mathrm{Cl}_{2}\right)_{2}\right](2.5)$} & RT & $8 \%$ \\
\hline 17 & DCE & NaOPiv (10) & $\mathrm{AgSbF}_{6}(10)$ & {$\left[\mathrm{Rh}\left(\mathrm{Cp}^{*} \mathrm{Cl}_{2}\right)_{2}\right](2.5)$} & 50 & $2 \%$ \\
\hline 18 & DCE & NaOPiv (10) & $\mathrm{AgSbF}_{6}(10)$ & {$\left[\mathrm{Rh}\left(\mathrm{Cp}^{*} \mathrm{Cl}_{2}\right)_{2}\right](1.25)$} & 50 & $\%$ \\
\hline
\end{tabular}

a) Pyridine 49 (0.100 mmol), IndoleBX $21(0.110 \mathrm{mmol}),\left[\mathrm{Rh}\left(\mathrm{Cp}^{*} \mathrm{Cl}_{2}\right)\right]_{2}(\mathrm{X} \mathrm{mol} \%)$, base $(\mathrm{X} \mathrm{mol} \%)$, additive $\left(\mathrm{X}\right.$ mol\%) and solvent $(0.1 \mathrm{M})$ at $\mathrm{T}^{\circ} \mathrm{C}$. Isolated yield after flash chromatography is given. b) Decomposition of the hypervalent iodine reagent $\mathbf{2 1}$ was observed.

To further facilitate a possible CMD (concerted metalation-deprotonation) at room temperature, we then screened carbonate and carboxylate salts instead of zinc(II) triflate. ${ }^{[107]}$ While potassium salts gave moderate yields (table 2, entries 8-10), sodium salts worked better. NaOAc afforded 52 in $69 \%$ yield and NaOPiv in $72 \%$ yield (table 2, entries 11-12). As $\mathrm{Ag}(\mathrm{I})$ salts are known to play a pivotal role in activating the catalyst by chloride abstraction to give ionic active species, ${ }^{[108]} \mathrm{AgNTf}_{2}$ and $\mathrm{AgSbF}_{6}$ were then examined as additive. In absence of a base, the former led to decomposition of the hypervalent iodine reagent $\mathbf{2 1}$, whereas the latter gave the desired product in $17 \%$ only (table 2, entries 13 and 14). Nevertheless, the combination of carboxylate bases and $\mathrm{AgSbF}_{6}$ increased the yield up to $90 \%$ (table 2, entry 15). Lowering the catalyst to $2.5 \mathrm{~mol} \%$ unfortunately led to lower yield at room temperature (table 2, entry 16), but $82 \%$ could be obtained when the temperature was increased to $50{ }^{\circ} \mathrm{C}$ (table 2, entry 17). When further lowering the catalyst loading, no full conversion could be obtained (table 2 , entry 18 ).

We then proceeded with the investigation of the scope of the new $\mathrm{C}-\mathrm{H}$ functionalization (scheme 5). Differently substituted IndoleBX were first used and gave the desired heteroarylated-arylpyridines in very good yields (scheme 5A). In particular, $\mathrm{NH}$-free indole product $\mathbf{5 4}$ could be accessed in $74 \%$, provided methanol was used as co-solvent for enhancing the solubility. A larger alkyl substituent on the nitrogen was also well tolerated (product 55). On the C5-indole position, an electron-donating methoxy group as well as electron-withdrawing halogens were well tolerated, and the products 56-59 were isolated in 74-89\% yields. We were also delighted to see that the pinacol boronate group was compatible with our method, as boronic ester 60 could be accessed in 59\% yield. When different PyrroleBX reagents were employed, the regioselective synthesis of products 61-65 became possible based on the availability of the pure reagent isomers (scheme $5 B$ ). In this case again, it was possible to access $N$ unprotected pyrrole $\mathbf{6 5}$ in 79\% yield. The presence of various functional groups on the aryl-pyridine substrate was then investigated (scheme 5C).
Again, methoxy and halogen groups were well tolerated (products 66-68). We were pleased to see that a cyano group could also be introduced, as 69 was obtained just by increasing the temperature to $80{ }^{\circ} \mathrm{C}$. Ester 70 was formed in nearly quantitative yield. Different other heterocyclic directing groups such as pyrimidines, pyrazoles and benzoquinolines could also be used (scheme 5D): products 71-73 were obtained in 72-81\% without the need for re-optimization of the reaction conditions. A pyrimidine directing group could also be used for the synthesis of C2-C3 indole dimer 74. Finally, with the double amount of IndoleBX 21, di-indolated product 75 was isolated in $53 \%$ yield (scheme $5 \mathrm{E}$ ).

Quinolones and purines are other classes of important heterocycles in bioactive compounds. As shown in Figure 9, quinolone 76 could be synthesized in $38 \%$ yield. In this case, quinoline $\mathrm{N}$-oxide was used as starting material. Functionalized purine base-containing nucleoside $\mathbf{7 7}$ could be also obtained via C-H functionalization in $41 \%$ yield. ${ }^{[109]}$

The obtained $\mathrm{C}-\mathrm{H}$ functionalization products based on heterocyclic directing groups are highly useful building blocks for medicinal chemistry or organic materials. Nevertheless, they constitute "synthetic end points", as the directing group cannot be easily removed. In order to enhance the synthetic versatility of the new $\mathrm{C}-\mathrm{H}$ arylation, we therefore turned to the recently developed ruthenium catalyzed $\mathrm{C}-\mathrm{H}$ functionalization of arenes using methoxy-amides directing groups (scheme 6). ${ }^{[56]}$ This directing group is simple to install and easily transformable. Moreover, ruthenium is a cheaper and more abundant metal. In this case, similar targeted products were already synthesized in the past, but only via cross-coupling reactions requiring pre-functionalization of the arene ring. ${ }^{[110]}$ Gratifyingly, when the conditions developed by Cheng and coworkers for $\mathrm{C}-\mathrm{H}$ alkynylation with EBX reagents ${ }^{[56]}$ were used with amide 78 and IndoleBX 21, the desired product 79 was obtained in 55\% yield (scheme 6). Control experiments showed that no direct C-H coupling with $\mathrm{N}$-methyl indole (14) was feasible under palladium- or rhodium-catalyzed conditions reported for this substrate (scheme 6 , conditions A-C). ${ }^{[18,105,111]}$ 


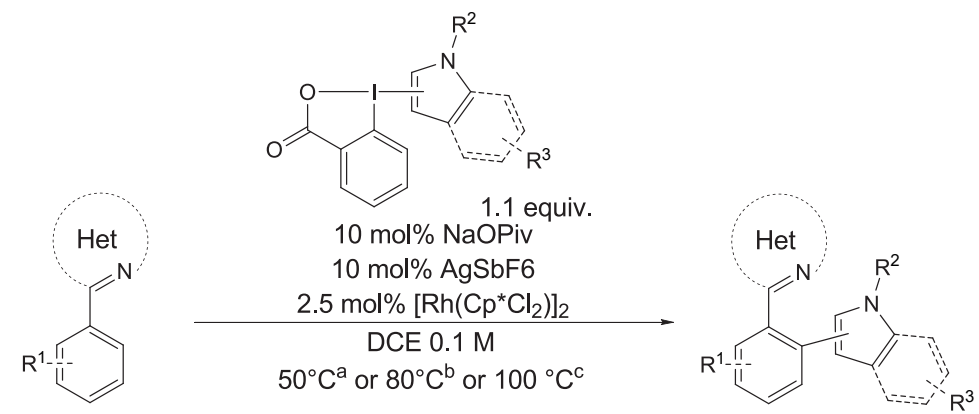

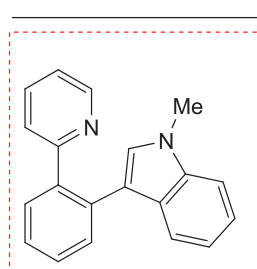

52

$82 \%$ yield

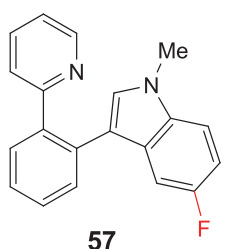

$73 \%$ yield

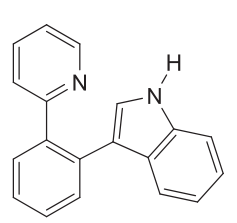

54

$74 \%$ yield $^{\mathrm{d}}$

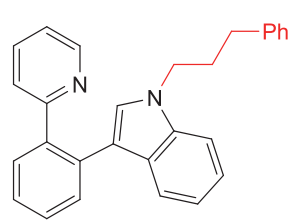

55
$74 \%$ yield $^{b}$

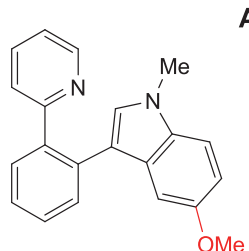

56

$89 \%$ yield
A

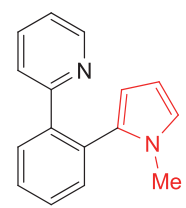

61

$83 \%$ yield $^{b}$

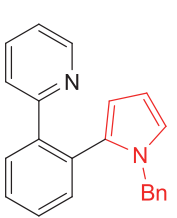

63

$68 \%$ yield $^{b}$

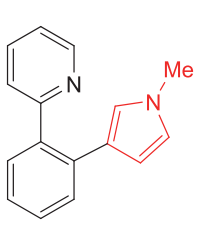

62

$85 \%$ yield $^{b}$

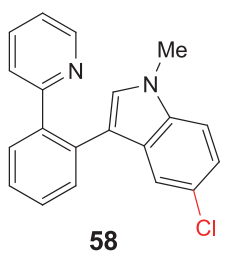

$81 \%$ yield

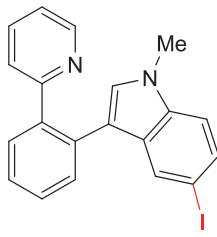

59

$74 \%$ yield

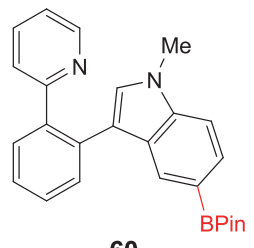

60

$59 \%$ yield

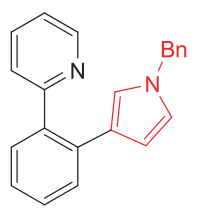

64

$58 \%$ yield $^{b}$

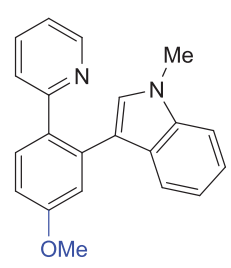

66 $88 \%$ yield

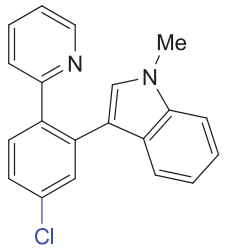

67

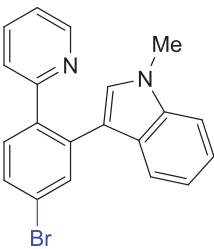

68

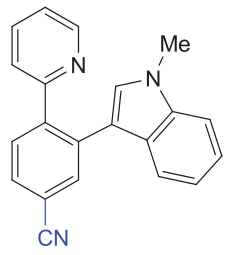

69 $84 \%$ yield $78 \%$ yield $^{b}$

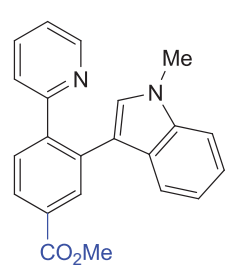

70

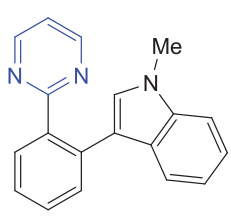

71

$81 \%$ yield $^{b}$

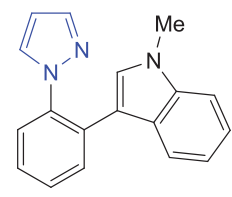

72

$72 \%$ yield

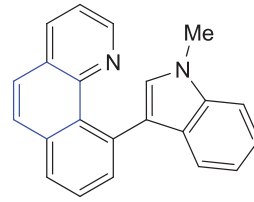

73

$76 \%$ yield

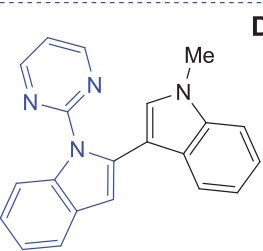

74

Scheme 5. Scope of the Rh-catalyzed C-H (hetero)arylation. a) Reaction conditions: substrate $(0.300 \mathrm{mmol})$, reagent $(0.330 \mathrm{mmol}),\left[\mathrm{Rh}\left(\mathrm{Cp}^{*} \mathrm{Cl} 2\right)\right]_{2}(2.5 \mathrm{~mol} \%), \mathrm{NaOPiv}(10 \mathrm{~mol} \%)$, $\operatorname{AgSbF}_{6}(10 \mathrm{~mol} \%)$ and DCE $(0.1 \mathrm{M})$ at $50^{\circ} \mathrm{C}$. Isolated yields. b) At $80^{\circ} \mathrm{C}$. c) At $100^{\circ} \mathrm{C}$. d) $0.1 \mathrm{M}$ in DCE:MeOH (1:1 ratio). e) $0.660 \mathrm{mmol}$ of IndoleBX $21 \mathrm{were}$ used.

Based on this promising result, the ruthenium-catalyzed $\mathrm{C}-\mathrm{H}$ indolation of benzamide $\mathbf{7 8}$ was further optimized. Screening of solvent showed the importance of a fluorinated alcohols, as methanol and ethanol led to lower yield of 79 (table 3, entries 1-3). Chlorinated solvents that worked well for the rhodium-catalyzed process such as DCM and DCE did not afford any conversion (table 3, entry 4). The choice of the base was also fundamental: sodium carboxylate bases gave the best result (table 3, entries 5-6), but none of the simple carboxylates initially tested were superior to sodium acetate (table 3 , entry 1 ). The corresponding potassium salts gave inferior results (table 3, entries 7-9). Based on these initial results, we decided to screen further sodium carboxylate salts (table 3, entries 10-13). While sodium benzoate $(\mathbf{8 0})$ led to no conversion (table 3 , entry 10). Adamantane-, xanthene- and diphenyl-based carboxylate salts 81-83 afforded the desired compound 79 in 65-68\% yield (table 3, entries 11-13) Although the three bases $\mathbf{8 1 - 8 3}$ afforded similar yields, adamantylcarboxylate base $\mathbf{8 1}$ led to a cleaner reaction profile. Different $\mathrm{Ag}(\mathrm{l})$ salts were also screened to further activate the catalyst, ${ }^{[82]}$ but they prevented the reaction to occur (table 3 , entry 14). 


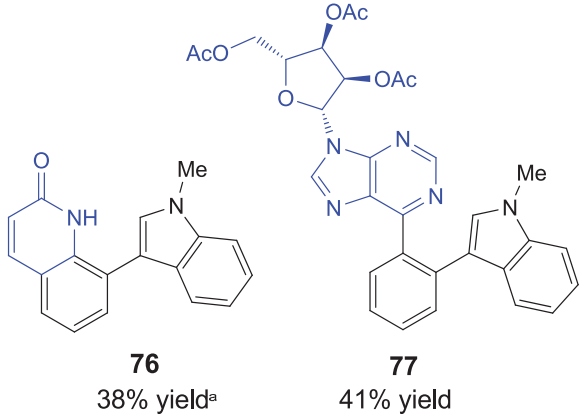

Figure 9. Indole-substituted quinolones and purines obtained by the Rh-catalyzed C$\mathrm{H}$ functionalization with IndoleBX 21. Reaction conditions: Substrate $(0.300 \mathrm{mmol})$, Indole source $(0.330 \mathrm{mmol}),\left[\mathrm{Rh}\left(\mathrm{Cp}^{*} \mathrm{Cl}_{2}\right)\right]_{2}(2.5 \mathrm{~mol} \%), \mathrm{NaOPiv}(10 \mathrm{~mol} \%), \mathrm{AgSbF}_{6}(10$ mol\%) and DCE (0.1 M) at $50^{\circ} \mathrm{C}$. Isolated yields. a) At $100^{\circ} \mathrm{C}$.

Finally, the expected active catalyst 84 was synthesized ${ }^{[112]}$ and used in the reaction (table 3 , entry 15 ). A similar result was obtained, but the protocol was more user friendly, as all reaction components could be added at the same time, only one degassing cycle had to be performed and no premixing was required. Moreover, the active complex was perfectly soluble in the reaction medium, allowing us to work under homogeneous condition.

We then performed preliminary investigations on the scope of the new ruthenium-catalyzed $\mathrm{C}-\mathrm{H}$ indolation, focusing this time on functional group substitution of the arene ring (figure 10). Substitution in para position to the amide was possible with both electron-rich (products $\mathbf{8 5}$ and $\mathbf{8 6}$ ) and electron-poor (products $\mathbf{8 7}$ and $\mathbf{8 8}$ ) substituents. A broad range of substituents was also tolerated in meta position (products 89-92). Double-substitution in both positions was also possible (product 93). Functionalized naphthyl amide $\mathbf{9 4}$ could also be obtained in $79 \%$ yield. The fast synthesis of halogenated arenes is especially interesting for application in medicinal chemistry, either for further functionalization via cross-coupling reactions, or due to the interesting properties of fluorine in drugs, especially for blocking metabolism and increasing lipophilicity.
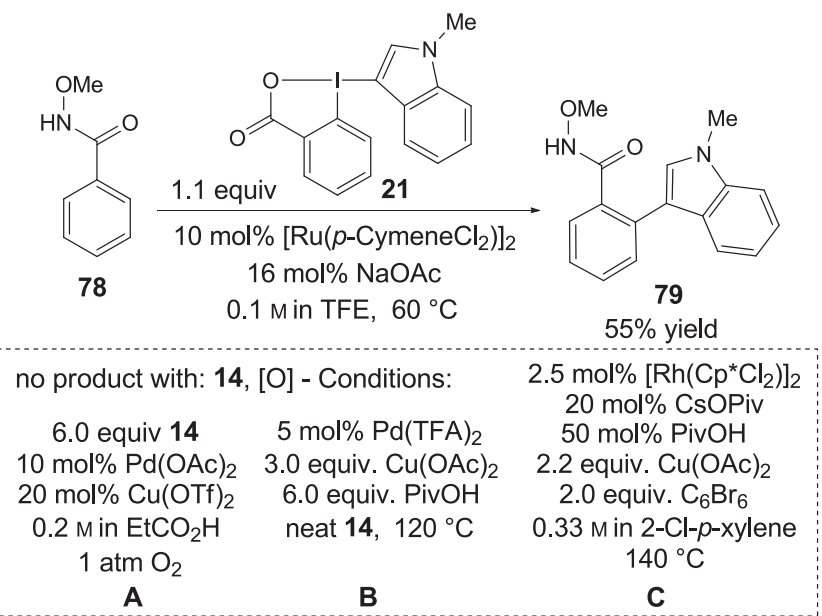

Scheme 6. Lead result for the Ru-catalyzed C-H indolation and control experiments.

Table 3. Optimization of the ruthenium-catalyzed $\mathrm{C}-\mathrm{H}$ indolation.

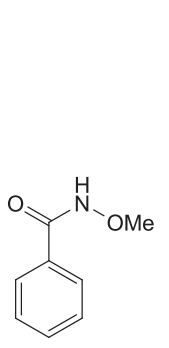

78

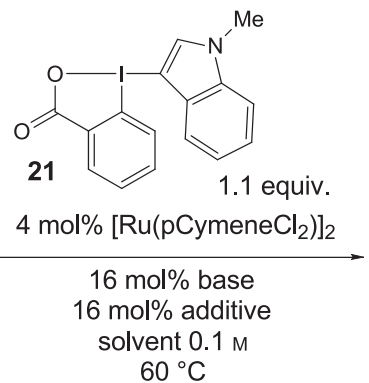

$60{ }^{\circ} \mathrm{C}$

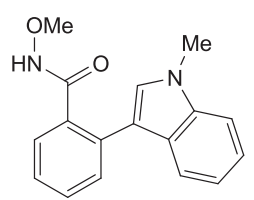

79

\begin{tabular}{|c|c|c|c|c|c|}
\hline Entry & Solvent (M) & Base (mol\%) & Additive (mol\%) & Ru (mol\%) & Yield $\%^{a}$ \\
\hline 1 & TFE & $\mathrm{NaOAc}(16)$ & - & {$\left[\mathrm{Ru}\left(p-C y m e n e C I_{2}\right)\right]_{2}(4)$} & $55 \%$ \\
\hline 2 & $\mathrm{MeOH}$ & $\mathrm{NaOAc}(16)$ & - & {$\left[\mathrm{Ru}\left(p-C y m e n e C I_{2}\right)\right]_{2}(4)$} & $43 \%$ \\
\hline 3 & $\mathrm{EtOH}$ & $\mathrm{NaOAc}(16)$ & - & {$\left[\mathrm{Ru}\left(p-C y m e n e C I_{2}\right)\right]_{2}(4)$} & $34 \%$ \\
\hline 4 & DCM/DCE & $\mathrm{NaOAc}(16)$ & - & {$\left[\mathrm{Ru}\left(p-C y m e n e C I_{2}\right)\right]_{2}(4)$} & - \\
\hline 5 & TFE & NaOPiv (16) & - & {$\left[\mathrm{Ru}\left(p-C y m e n e C I_{2}\right)\right]_{2}(4)$} & $50 \%$ \\
\hline 6 & TFE & MesCOONa (16) & - & {$\left[\mathrm{Ru}\left(p-C y m e n e C I_{2}\right)\right]_{2}(4)$} & $34 \%$ \\
\hline 7 & TFE & KOAC (16) & - & {$\left[\mathrm{Ru}\left(p-\mathrm{CymeneCl}_{2}\right)\right]_{2}(4)$} & - \\
\hline 8 & TFE & KOPiv (16) & - & {$\left[\mathrm{Ru}\left(p-\text { CymeneCl }_{2}\right)\right]_{2}(4)$} & - \\
\hline 9 & TFE & MesCOOK (16) & - & {$\left[\mathrm{Ru}\left(p-\text { CymeneCl }_{2}\right)\right]_{2}(4)$} & $26 \%$ \\
\hline 10 & TFE & $80(16)$ & - & {$\left[\mathrm{Ru}\left(p-C y m e n e C I_{2}\right)\right]_{2}(4)$} & - \\
\hline 11 & TFE & $81(16)$ & - & {$\left[\mathrm{Ru}\left(p-C y m e n e C \mathrm{Cl}_{2}\right)\right]_{2}(4)$} & $68 \%$ \\
\hline 12 & TFE & $82(16)$ & - & {$\left[\mathrm{Ru}\left(p-C y m e n e \mathrm{Cl}_{2}\right)\right]_{2}(4)$} & $65 \%^{\mathrm{b}}$ \\
\hline
\end{tabular}


13

14

15
TFE

TFE

TFE
83 (16)

81 (16)
(O)

80

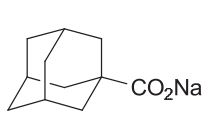

81<smiles>NC(=O)C1c2ccccc2Oc2ccccc21</smiles>

82<smiles>N#CC(=O)C(c1ccccc1)c1ccccc1</smiles>

83
$\left[\mathrm{Ru}\left(p-\text { CymeneCl } \mathrm{I}_{2}\right)\right]_{2}(4)$

$66 \%^{\mathrm{b}}$

$\operatorname{Ag}(I) X(16)-$

$\left[\mathrm{Ru}\left(p-\text { CymeneCl}_{2}\right)\right]_{2}(4)$

a) Substrate $78(0.100 \mathrm{mmol})$, IndoleBX $21(0.110 \mathrm{mmol})$, $\left[\mathrm{Ru}\left(p-C y m e n e C l_{2}\right)\right]_{2}(\mathrm{X} \mathrm{mol} \%)$, base $(\mathrm{X} \mathrm{mol} \%)$, additive $\left(\mathrm{X}\right.$ mol\%) and solvent $(0.1 \mathrm{M})$ at $\mathrm{T}{ }^{\circ} \mathrm{C}$. Isolated yield after flash chromatography is given. b) Decomposition was observed.

\section{Conclusions}

In this work, a full account of the synthesis of the hypervalent iodine reagents IndoleBX and PyrroleBX as a novel class of bench-stable electrophilic indole and pyrrole equivalents and their application in $\mathrm{Rh}$ (III) and $\mathrm{Ru}(\mathrm{II})$ catalyzed $\mathrm{C}-\mathrm{H}$ (hetero)arylation of different arenes is described. In total 33 new hypervalent iodine reagents are reported. A broad range of different substituents could be introduced on the heterocycle and on the reagents backbone. $\mathrm{N}$-Methyl-IndoleBX $\mathbf{2 1}$ was accessible on gram scale and presents high thermal stability. Based on the use of these new reagents, indoles and pyrroles were transferred directly on the $\mathrm{C}-\mathrm{H}$ bond of various arenes in a mild, chemo- and regio-selective fashion. While $\mathrm{Rh}$ (III) was employed in combination with a heterocyclic nitrogen donor directing group, $\mathrm{Ru}(\mathrm{II})$ enabled the functionalization of versatile arylmethoxamides. The two methods were robust, and a broad scope was obtained as several functional groups were well tolerated. The synthesis and novel applications of heterocyclic-based hypervalent iodine reagents has just started in our laboratory and important progress can be expected in the future.

\section{Supplementary Material}

Supporting information for this article is available on the WWW under http://dx.doi.org/10.1002/MS-number.

\section{Acknowledgements}

This work is supported by the Swiss National Science Founda-tion (No. 200021 159920), the European Research Council (ERCStarting Grant 334840) and the COST action CA15106 (C-H Activation in Organic Synthesis, CHAOS). We thank Dr R. Scopelliti and Dr F. F. Tirani from ISIC at EPFL for Xray analysis, and Dr.Fides Benfatti and Ms. Marylene Stempien from Syngenta CropScience for DSC experiments. Dr. Stefano Nicolai from EPFL is thanked for revising the manuscript.

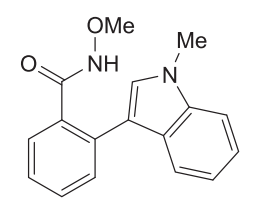

79

$68 \%$ yield

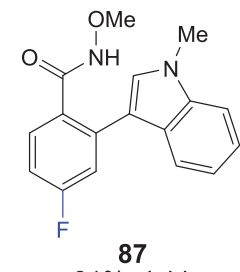

87
$81 \%$ yield

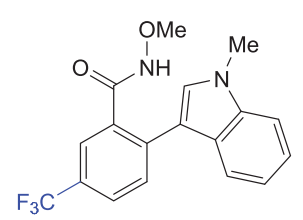

90

$60 \%$ yield
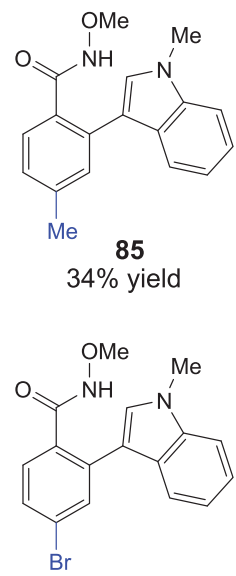

88

$84 \%$ yield

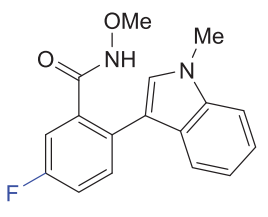

91

$75 \%$ yield
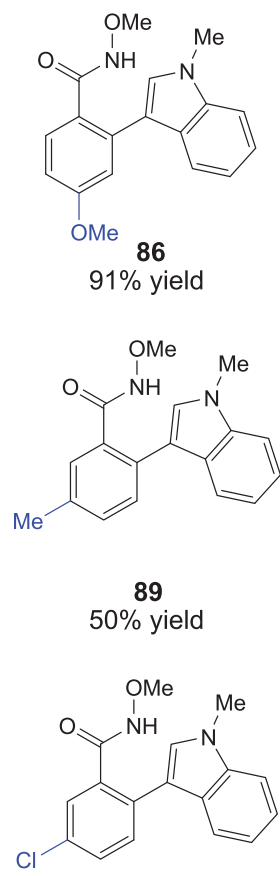

$75 \%$ yield
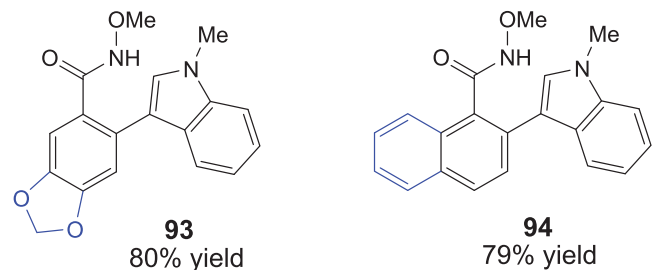

Figure 10. Scope of the Ru-catalyzed $\mathrm{C}-\mathrm{H}$ (hetero)arylation. Reaction conditions: Substrate $(0.300 \mathrm{mmol})$, IndoleBX $21(0.330 \mathrm{mmol}), 84(10 \mathrm{~mol} \%)$, and TFE $(0.1 \mathrm{M})$ at $60^{\circ} \mathrm{C}$.

\section{References}

[1] G. W. Gribble, 'Indole Ring Synthesis: From Natural Products to Drug Discovery', Indole Ring Synthesis: From Natural Products to Drug Discovery, John Wiley \& Sons, Inc., 2016.

[2] M. Ishikura, T. Abe, T. Choshi, S. Hibino, 'Simple indole alkaloids and those with a non-rearranged monoterpenoid unit', Nat. Prod. Rep. 2013, 30, 694-752.

[3] A. Baeyer, 'Ueber die Reduction aromatischer Verbindungen mittelst Zinkstaub', 
Justus Liebigs Ann. Chem. 1866, 140, 295-296.

[4] R. B. Woodward, F. E. Bader, H. Bickel, A. J. Frey, R. W. Kierstead, 'The Total Synthesis of Reserpine', J. Am. Chem. Soc. 1956, 78, 2023-2025.

[5] A. K. Pitts, F. O'Hara, R. H. Snell, M. J. Gaunt, 'A Concise and Scalable Strategy for the Total Synthesis of Dictyodendrin B Based on Sequential C-H Functionalization', Angew. Chem., Int. Ed. 2015, 54, 5451-5455.

[6] A. D. Yamaguchi, K. M. Chepiga, J. Yamaguchi, K. Itami, H. M. L. Davies, 'Concise Syntheses of Dictyodendrins $\mathrm{A}$ and $\mathrm{F}$ by a Sequential $\mathrm{C}-\mathrm{H}$ Functionalization Strategy', J. Am. Chem. Soc. 2015, 137, 644-647.

[7] J. K. Liao, U. Laufs, 'PLEIOTROPIC EFFECTS OF STATINS', Annu. Rev. Pharmacol. Toxicol. 2004, 45, 89-118.

[8] G. R. Humphrey, J. T. Kuethe, 'Practical Methodologies for the Synthesis of Indoles', Chem. Rev. 2006, 106, 2875-2911.

[9] Richard Sundberg, 'The Chemistry of Indoles', The Chemistry of Indoles, Elsevier, 1970.

[10] J. J. Li, G. W. Gribble, 'Metal-Catalyzed Cross-Coupling Reactions for Indoles BT Heterocyclic Scaffolds II: Reactions and Applications of Indoles', in (Ed.: G.W. Gribble), Springer Berlin Heidelberg, Berlin, Heidelberg, 2010, pp. 193-234.

[11] G. Bartoli, G. Bencivenni, R. Dalpozzo, 'Organocatalytic strategies for the asymmetric functionalization of indoles', Chem. Soc. Rev. 2010, 39, 4449-4465.

[12] S. Cacchi, G. Fabrizi, 'Synthesis and Functionalization of Indoles Through Palladium-catalyzed Reactions', Chem. Rev. 2005, 105, 2873-2920.

[13] N. R. Deprez, D. Kalyani, A. Krause, M. S. Sanford, 'Room Temperature PalladiumCatalyzed 2-Arylation of Indoles', J. Am. Chem. Soc. 2006, 128, 4972-4973.

[14] R. J. Phipps, N. P. Grimster, M. J. Gaunt, 'Cu(II)-Catalyzed Direct and Site-Selective Arylation of Indoles Under Mild Conditions', J. Am. Chem. Soc. 2008, 130, 81728174.

[15] L. Ackermann, M. Dell'Acqua, S. Fenner, R. Vicente, R. Sandmann, 'Metal-Free Direct Arylations of Indoles and Pyrroles with Diaryliodonium Salts', Org. Lett. 2011, 13, 2358-2360.

[16] E. A. Merritt, B. Olofsson, 'Diaryliodonium Salts: A Journey from Obscurity to Fame', Angew. Chem., Int. Ed. 2009, 48, 9052-9070.

[17] D. R. Stuart, K. Fagnou, 'The Catalytic Cross-Coupling of Unactivated Arenes', Science, 2007, 316, 1172.

[18] D. R. Stuart, E. Villemure, K. Fagnou, 'Elements of Regiocontrol in PalladiumCatalyzed Oxidative Arene Cross-Coupling', J. Am. Chem. Soc. 2007, 129, 12072 12073.

[19] X. Gong, G. Song, H. Zhang, X. Li, 'Palladium-Catalyzed Oxidative Cross-Coupling between Pyridine N-Oxides and Indoles', Org. Lett. 2011, 13, 1766-1769.

[20] Z. Wang, F. Song, Y. Zhao, Y. Huang, L. Yang, D. Zhao, J. Lan, J. You, 'Elements of Regiocontrol in the Direct Heteroarylation of Indoles/Pyrroles: Synthesis of Biand Fused Polycyclic Heteroarenes by Twofold or Tandem Fourfold C-H Activation', Chem. Eur. J. 2012, 18, 16616-16620.

[21] N. Kuhl, M. N. Hopkinson, F. Glorius, 'Selective Rhodium(III)-Catalyzed CrossDehydrogenative Coupling of Furan and Thiophene Derivatives', Angew. Chem., Int. Ed. 2012, 51, 8230-8234.

[22] M. Nishino, K. Hirano, T. Satoh, M. Miura, 'Copper-Mediated and CopperCatalyzed Cross-Coupling of Indoles and 1,3-Azoles: Double C-H Activation', Angew. Chem., Int. Ed. 2012, 51, 6993-6997.

[23] X. Qin, H. Liu, D. Qin, Q. Wu, J. You, D. Zhao, Q. Guo, X. Huang, J. Lan, 'Chelationassisted $\mathrm{Rh}(\mathrm{III})$-catalyzed $\mathrm{C} 2$-selective oxidative $\mathrm{C}-\mathrm{H} / \mathrm{C}-\mathrm{H}$ cross-coupling of indoles/pyrroles with heteroarenes', Chem. Sci. 2013, 4, 1964-1969.

[24] K. Morimoto, K. Sakamoto, T. Ohshika, T. Dohi, Y. Kita, 'Organo-lodine(III)Catalyzed Oxidative Phenol-Arene and Phenol-Phenol Cross-Coupling Reaction', Angew. Chem., Int. Ed 2016, 55, 3652-3656.

[25] C.-Y. He, Q.-Q. Min, X. Zhang, 'Palladium-Catalyzed Aerobic Dehydrogenative
Cross-Coupling of Polyfluoroarenes with Thiophenes: Facile Access to Polyfluoroarene-Thiophene Structure', Organometallics 2012, 31, 1335-1340.

[26] X. C. Cambeiro, N. Ahlsten, I. Larrosa, 'Au-Catalyzed Cross-Coupling of Arenes via Double C-H Activation', J. Am. Chem. Soc. 2015, 137, 15636-15639.

[27] M. Bandini, 'Electrophilicity: the "dark-side" of indole chemistry', Org. Biomol. Chem. 2013, 11, 5206-5212.

[28] V. V Zhdankin, 'Hypervalent lodine Chemistry: Preparation, Structure, and Synthetic Applications of Polyvalent lodine Compounds, Wiley', Hypervalent lodine Chemistry: Preparation, Structure, and Synthetic Applications of Polyvalent lodine Compounds, Wiley, 2014.

[29] T. Wirth, 'Hypervalent lodine Chemistry', Hypervalent lodine Chemistry, Springer International Publishing, 2016.

[30] T. Wirth, 'Hypervalent lodine Chemistry in Synthesis: Scope and New Directions', Angew. Chem., Int. Ed. 2005, 44, 3656-3665.

[31] A. Yoshimura, V. V Zhdankin, 'Advances in Synthetic Applications of Hypervalent lodine Compounds', Chem. Rev. 2016, 116, 3328-3435.

[32] Y. Li, D. P. Hari, M. V. Vita, J. Waser, 'Cyclic Hypervalent lodine Reagents for AtomTransfer Reactions: Beyond Trifluoromethylation', Angew. Chem., Int. Ed. 2016, 55, 4436-4454.

[33] T. Dohi, K. Morimoto, A. Maruyama, Y. Kita, 'Direct Synthesis of Bipyrroles Using Phenyliodine Bis(trifluoroacetate) with Bromotrimethylsilane', Org. Lett. 2006, 8, 2007-2010.

[34] K. C. Nicolaou, S. M. Dalby, S. Li, T. Suzuki, D. Y.-K. Chen, 'Total Synthesis of (+)Haplophytine', Angew. Chem., Int. Ed. 2009, 48, 7616-7620.

[35] B. Y. Karele, L. é. Treigute, S. V Kalnin', I. P. Grinberga, O. Y. Neiland, 'lodonium derivatives of heterocyclic compounds', Chem. Heterocycl. Compd. 1974, 10, 189192.

[36] O. Neilands, 'Phenyliodonium Derivatives of N-Heterocycles and CH-Acids, Their Synthesis, and Their Use in the Chemistry of Heterocycles', Chem. Heterocycl. Compd. 2003, 39, 1555-1569.

[37] V. A. Budylin, M. S. Ermolenko, F. A. Chugtai, A. N. Kost, 'Peculiarities of nucleophilic substitution in indolyliodonium salts', Chem. Heterocycl. Compd. 1981, 17, 1088-1090.

[38] V. A. Budylin, M. S. Ermolenko, F. A. Chugtai, P. A. Sharbatyan, A. N. Kost, 'Reaction of 3-indolylphenyliodonium betaine with electrophilic agents', Chem. Heterocycl. Compd. 1981, 17, 1095-1097.

[39] R. M. Moriarty, Y. Y. Ku, M. Sultana, A. Tuncay, 'A new carbon-carbon bond forming reaction in indole chemistry. C3-Arylation and alkylation with phenyl ( $\beta$ indolyl) iodonium trifluoroacetate', Tetrahedron Lett. 1987, 28, 3071-3074.

[40] D. Lubriks, I. Sokolovs, E. Suna, 'Indirect C-H Azidation of Heterocycles via Copper-Catalyzed Regioselective Fragmentation of Unsymmetrical $\lambda_{3}$-lodanes', J. Am. Chem. Soc. 2012, 134, 15436-15442.

[41] I. Sokolovs, D. Lubriks, E. Suna, 'Copper-Catalyzed Intermolecular C-H Amination of (Hetero)arenes via Transient Unsymmetrical $\lambda 3$-lodanes', J. Am. Chem. Soc. 2014, 136, 6920-6928.

[42] K. Moriyama, K. Ishida, H. Togo, 'Regioselective Csp2-H dual functionalization of indoles using hypervalent iodine(III): bromo-amination via 1,3-migration of imides on indolyl(phenyl)iodonium imides', Chem. Commun. 2015, 51, 22732276.

[43] K. Ishida, H. Togo, K. Moriyama, 'Preparation of Heteroaromatic (Aryl)iodonium Imides as I-N Bond-Containing Hypervalent lodine', Chem. - An Asian J. 2016, 11, 3583-3588.

[44] K. Morimoto, Y. Ohnishi, D. Koseki, A. Nakamura, T. Dohi, Y. Kita, 'Stabilized pyrrolyl iodonium salts and metal-free oxidative cross-coupling', Org. Biomol. Chem. 2016, DOI 10.1039/C6OB01764A.

[45] C. Liu, J.-C. Yi, X.-W. Liang, R.-Q. Xu, L.-X. Dai, S.-L. You, 'Copper(I)-Catalyzed 
Asymmetric Dearomatization of Indole Acetamides with 3Indolylphenyliodonium Salts', Chem. - A Eur. J. 2016, 22, 10813-10816.

[46] J. P. Brand, J. Waser, 'Electrophilic alkynylation: the dark side of acetylene chemistry', Chem. Soc. Rev. 2012, 41, 4165-4179.

[47] J. Waser, 'Alkynylation with Hypervalent lodine Reagents', in Hypervalent lodine Chem. (Ed.: T. Wirth), Springer International Publishing, Cham, 2016, pp. 187-222.

[48] J. P. Brand, J. Charpentier, J. Waser, 'Direct Alkynylation of Indole and Pyrrole Heterocycles', Angew. Chem., Int. Ed. 2009, 48, 9346-9349.

[49] J. P. Brand, J. Waser, 'Direct Alkynylation of Thiophenes: Cooperative Activation of TIPS-EBX with Gold and Brønsted Acids', Angew. Chem., Int. Ed. 2010, 49, 7304-7307.

[50] G. L. Tolnai, S. Ganss, J. P. Brand, J. Waser, 'C2-Selective Direct Alkynylation of Indoles', Org. Lett. 2013, 15, 112-115.

[51] Y. Li, J. Waser, 'Zinc-gold cooperative catalysis for the direct alkynylation of benzofurans', Beilstein J. Org. Chem. 2013, 9, 1763-1767.

[52] F. Xie, Z. Qi, S. Yu, X. Li, 'Rh(III)- and Ir(III)-Catalyzed C-H Alkynylation of Arenes under Chelation Assistance', J. Am. Chem. Soc. 2014, 136, 4780-4787.

[53] C. Feng, T.-P. Loh, 'Rhodium-Catalyzed C-H Alkynylation of Arenes at Room Temperature', Angew. Chem., Int. Ed. 2014, 53, 2722-2726.

[54] K. D. Collins, F. Lied, F. Glorius, 'Preparation of conjugated 1,3-enynes by Rh(III)catalysed alkynylation of alkenes via C-H activation', Chem. Commun. 2014, 50, 4459-4461.

[55] P. Finkbeiner, U. Kloeckner, B. J. Nachtsheim, 'OH-Directed Alkynylation of 2Vinylphenols with Ethynyl Benziodoxolones: A Fast Access to Terminal 1,3Enynes', Angew. Chem., Int. Ed. 2015, 54, 4949-4952.

[56] R. Boobalan, P. Gandeepan, C.-H. Cheng, 'Ruthenium-Catalyzed C-H Alkynylation of Aromatic Amides with Hypervalent lodine-Alkyne Reagents', Org. Lett. 2016, 18, 3314-3317.

[57] G. L. Tolnai, J. P. Brand, J. Waser, 'Gold-catalyzed direct alkynylation of tryptophan in peptides using TIPS-EBX', Beilstein J. Org. Chem. 2016, 12, 745-749.

[58] L. D. Caspers, P. Finkbeiner, B. J. Nachtsheim, 'Direct Electrophilic C-H Alkynylation of Unprotected 2-Vinylanilines', Chem. Eur. J. 2017, 23, 2748-2752.

[59] K. T. Neumann, S. R. Laursen, A. T. Lindhardt, B. Bang-Andersen, T. Skrydstrup, 'Palladium-Catalyzed Carbonylative Sonogashira Coupling of Aryl Bromides Using Near Stoichiometric Carbon Monoxide', Org. Lett. 2014, 16, 2216-2219.

[60] P. Caramenti, S. Nicolai, J. Waser, 'Indole- and Pyrrole-BX: Bench-Stable Hypervalent lodine Reagents for Heterocycle Umpolung', Chem. - A Eur. J., 2017 DOI: 10.1002/chem.201703723.

[61] J. P. Brand, C. Chevalley, J. Waser, 'One-pot gold-catalyzed synthesis of 3silylethynyl indoles from unprotected o-alkynylanilines', Beilstein J. Org. Chem. 2011, 7, 565-569.

[62] Y. Li, J. P. Brand, J. Waser, 'Gold-Catalyzed Regioselective Synthesis of 2- and 3Alkynyl Furans', Angew. Chem., Int. Ed. 2013, 52, 6743-6747.

[63] Y. Li, J. Waser, 'Platinum-Catalyzed Domino Reaction with Benziodoxole Reagents for Accessing Benzene-Alkynylated Indoles', Angew. Chem., Int. Ed. 2015, 54, 5438-5442.

[64] Y. Li, G. Gryn'ova, F. Saenz, X. Jeanbourquin, K. Sivula, C. Corminboeuf, J. Waser, 'Heterotetracenes: Flexible Synthesis and in Silico Assessment of the HoleTransport Properties', Chem. - A Eur. J. 2017, 23, 8058-8065.

[65] H. Ghari, Y. Li, R. Roohzadeh, P. Caramenti, J. Waser, A. Ariafard, 'Gold-catalyzed domino cyclization-alkynylation reactions with EBX reagents: new insights into the reaction mechanism', Dalt. Trans. 2017, DOI 10.1039/C7DT03154H.

[66] V. V Zhdankin, A. P. Krasutsky, C. J. Kuehl, A. J. Simonsen, J. K. Woodward, B. Mismash, J. T. Bolz, 'Preparation, X-ray Crystal Structure, and Chemistry of Stable AzidoiodinanesDerivatives of Benziodoxole', J. Am. Chem. Soc. 1996, 118, 5192 5197.
[67] G. A. Rabah, G. F. Koser, 'Facile synthetic entry into the 1,3-dihydro-3-methyl-3phenyl-1,2-benziodoxole family of $\lambda$ 3-lodanes', Tetrahedron Lett. 1996, 37, 64536456.

[68] H. T. Yasuyuki Kita, Shuji Akai, Takayuki Okuno, Masahiro Egi, Takeshi Takada, 'Preparation of Novel Cyclic Hypervalent Idoine(III) Compounds Having Azido, Cyano, and Nitrato Ligands', Heterocycles 1996, 42, 47-51.

[69] S. Bräse, C. Gil, K. Knepper, V. Zimmermann, 'Organic Azides: An Exploding Diversity of a Unique Class of Compounds', Angew. Chem., Int. Ed. 2005, 44, 51885240.

[70] Q.-H. Deng, T. Bleith, H. Wadepohl, L. H. Gade, 'Enantioselective Iron-Catalyzed Azidation of $\beta$-Keto Esters and Oxindoles', J. Am. Chem. Soc. 2013, 135, 53565359.

[71] M. V. Vita, J. Waser, 'Azidation of $\beta$-Keto Esters and Silyl Enol Ethers with a Benziodoxole Reagent', Org. Lett. 2013, 15, 3246-3249.

[72] B. Zhang, A. Studer, 'Stereoselective Radical Azidooxygenation of Alkenes', Org. Lett. 2013, 15, 4548-4551.

[73] W. Kong, E. Merino, C. Nevado, 'Arylphosphonylation and Arylazidation of Activated Alkenes', Angew. Chem., Int. Ed. 2014, 53, 5078-5082.

[74] A. Sharma, J. F. Hartwig, 'Metal-catalysed azidation of tertiary C-H bonds suitable for late-stage functionalization', Nature 2015, 517, 600-604.

[75] M. V. Vita, P. Caramenti, J. Waser, 'Enantioselective Synthesis of Homoallylic Azides and Nitriles via Palladium-Catalyzed Decarboxylative Allylation', Org. Lett. 2015, 17, 5832-5835.

[76] X. Huang, J. T. Groves, 'Taming Azide Radicals for Catalytic C-H Azidation', ACS Catal. 2016, 6, 751-759.

[77] P. T. G. Rabet, G. Fumagalli, S. Boyd, M. F. Greaney, 'Benzylic C-H Azidation Using the Zhdankin Reagent and a Copper Photoredox Catalyst', Org. Lett. 2016, 18, 1646-1649.

[78] S. Alazet, F. Le Vaillant, S. Nicolai, T. Courant, J. Waser, 'Divergent Access to $(1,1)$ and (1,2)-Azidolactones from Alkenes using Hypervalent lodine Reagents', Chem. Eur. J. 2017, 23, 9501-9504.

[79] Togni Antonio, Daniel Stolz, Ján Cvengroš, 'A Concise Synthesis of ortholodobenzyl Alcohols via Addition of ortho-lodophenyl Grignard Reagent to Aldehydes and Ketones', Synthesis (Stuttg). 2009, 2818-2824.

[80] S. Zhou, J. Wang, L. Wang, K. Chen, C. Song, J. Zhu, 'Co(III)-Catalyzed, Internal and Terminal Alkyne-Compatible Synthesis of Indoles', Org. Lett. 2016, 18, 3806-3809.

[81] S. Syu, Y.-T. Lee, Y.-J. Jang, W. Lin, 'Preparation of Functional Benzofurans, Benzothiophenes, and Indoles Using Ester, Thioester, and Amide via Intramolecular Wittig Reactions', Org. Lett. 2011, 13, 2970-2973.

[82] 'See Supplementary Information'.

[83] P. Eisenberger, S. Gischig, A. Togni, 'Novel 10-I-3 Hypervalent lodine-Based Compounds for Electrophilic Trifluoromethylation', Chem. Eur. J. 2006, 12, 25792586.

[84] R. Koller, K. Stanek, D. Stolz, R. Aardoom, K. Niedermann, A. Togni, 'Zinc-Mediated Formation of Trifluoromethyl Ethers from Alcohols and Hypervalent lodine Trifluoromethylation Reagents', Angew. Chem., Int. Ed. 2009, 48, 4332-4336.

[85] D. Fernández González, J. P. Brand, J. Waser, 'Ethynyl-1,2-benziodoxol-3(1区H)one (EBX): An Exceptional Reagent for the Ethynylation of Keto, Cyano, and Nitro Esters', Chem. Eur. J. 2010, 16, 9457-9461.

[86] A. T. Parsons, S. L. Buchwald, 'Copper-Catalyzed Trifluoromethylation of Unactivated Olefins', Angew. Chem., Int. Ed. 2011, 50, 9120-9123.

[87] L. Chan, A. McNally, Q. Y. Toh, A. Mendoza, M. J. Gaunt, 'A counteranion triggered arylation strategy using diaryliodonium fluorides', Chem. Sci. 2015, 6, 1277-1281.

[88] E. A. Merritt, B. Olofsson, 'Synthesis of a Range of lodine(III) Compounds Directly from lodoarenes', Eur. J. Org. Chem. 2011, 2011, 3690-3694.

[89] M. S. Yusubov, R. Y. Yusubova, V. N. Nemykin, V. V Zhdankin, 'Preparation and X- 
ray Structural Study of 1-Arylbenziodoxolones', J. Org. Chem. 2013, 78, 37673773.

[90] 'For a database of stability data on benziodoxole reagents, see: https://lcso.epfl.ch/BXStabilityData'.

[91] T. Nabana, H. Togo, 'Reactivities of Novel [Hydroxy(tosyloxy)iodo]arenes and [Hydroxy(phosphoryloxy)iodo]arenes for a-Tosyloxylation and aPhosphoryloxylation of Ketones', J. Org. Chem. 2002, 67, 4362-4365.

[92] Y. Kita, K. Morimoto, M. Ito, C. Ogawa, A. Goto, T. Dohi, 'Metal-Free Oxidative Cross-Coupling of Unfunctionalized Aromatic Compounds', J. Am. Chem. Soc. 2009, 131, 1668-1669.

[93] B. Wang, J. W. Graskemper, L. Qin, S. G. DiMagno, 'Regiospecific Reductive Elimination from Diaryliodonium Salts', Angew. Chem., Int. Ed. 2010, 49, 40794083.

[94] T. Kasahara, Y. J. Jang, L. Racicot, D. Panagopoulos, S. H. Liang, M. A. Ciufolini, 'Iodonium Metathesis Reactions', Angew. Chem., Int. Ed. 2014, 53, 9637-9639.

[95] P. An, Z. Yu, Q. Lin, 'Design of oligothiophene-based tetrazoles for laser-triggered photoclick chemistry in living cells', Chem. Commun. 2013, 49, 9920-9922.

[96] Y. Tian, M. P. Jacinto, Y. Zeng, Z. Yu, J. Qu, W. R. Liu, Q. Lin, 'Genetically Encoded 2-Aryl-5-carboxytetrazoles for Site-Selective Protein Photo-Cross-Linking', J. Am. Chem. Soc. 2017, 139, 6078-6081.

[97] J. Zhao, S. Li, 'Charge-Transfer-Induced para-Selective sp2 C-H Bond Activation of Arenes by Use of a Hypervalent lodine Compound: A Theoretical Study', J. Org. Chem. 2017, 82, 2984-2991.

[98] K. Stanek, R. Koller, A. Togni, 'Reactivity of a 10-I-3 Hypervalent lodine Trifluoromethylation Reagent With Phenols', J. Org. Chem. 2008, 73, 7678-7685.

[99] H. K. Y. Shin Chang Ju, Kim Young Kwon, Kim Hyung Sun, Park Moo Jin, Seo Joo He, Yu Eun Sun, Choi Byoung Ki, 'KR20150027937 (A) - Condensed compound and organic light emitting diode including the same', KR20150027937 (A) Condensed Compound and Organic Light Emitting Diode Including the Same, 2015, KR20130106306 20130904.

[100] Z. S. Jin-Quan Yu, 'Topics in Current Chemistry: C-H Activation', Topics in Current Chemistry: C-H Activation, Springer, 2010.

[101] M. W. Hooper, M. Utsunomiya, J. F. Hartwig, 'Scope and Mechanism of Palladium-Catalyzed Amination of Five-Membered Heterocyclic Halides', J. Org. Chem. 2003, 68, 2861-2873.

[102] B. A. Witulski Javier Ramon; Alayrac, Carole; Arnautu, Anca; Collot, Valerie; Rault, Sylvain, 'Sequential Sonogashira and Suzuki Cross-Coupling Reactions in the Indole and Indazole Series', 2005, 771-780.

[103] D. S. G. Spinella A. Izzo I., 'A Pd-Mediated Approach to the Synthesis of an Unusual $\beta$-Hydroxy-tryptophan Amino Acid Constituent of Cyclomarin A', 2006, 1319-1322.

[104] S.-D. Yang, C.-L. Sun, Z. Fang, B.-J. Li, Y.-Z. Li, Z.-J. Shi, 'Palladium-Catalyzed Direct Arylation of (Hetero)Arenes with Aryl Boronic Acids', Angew. Chem., Int. Ed. 2008, 47, 1473-1476.

[105] J. Wencel-Delord, C. Nimphius, H. Wang, F. Glorius, 'Rhodium(III) and Hexabromobenzene-A Catalyst System for the Cross-Dehydrogenative Coupling of Simple Arenes and Heterocycles with Arenes Bearing Directing Groups', Angew. Chem., Int. Ed. 2012, 51, 13001-13005.

[106] J. Malmgren, S. Santoro, N. Jalalian, F. Himo, B. Olofsson, 'Arylation with Unsymmetrical Diaryliodonium Salts: A Chemoselectivity Study', Chem. Eur. J. 2013, 19, 10334-10342.

[107] L. Ackermann, 'Carboxylate-Assisted Transition-Metal-Catalyzed C-H Bond Functionalizations: Mechanism and Scope', Chem. Rev. 2011, 111, 1315-1345.

[108] M. D. Lotz, N. M. Camasso, A. J. Canty, M. S. Sanford, 'Role of Silver Salts in Palladium-Catalyzed Arene and Heteroarene C-H Functionalization Reactions', Organometallics 2017, 36, 165-171.
[109] 'Reagents 16-17, 23, 26, 33-34, 38, 43-46 were screened for $\mathrm{Rh}$ (III) and $\mathrm{Ru}(\mathrm{II})$ catalyzed $\mathrm{C}-\mathrm{H}$ activation of arenes with poor or no results.'.

[110] G. Li, E. Wang, H. Chen, H. Li, Y. Liu, P. G. Wang, 'A general and efficient synthesis of substituted fluorenes and heterocycle-fused indenes containing thiophene or indole rings utilizing a Suzuki-Miyaura coupling and acidcatalyzed Friedel-Crafts reactions as key steps', Tetrahedron 2008, 64, 90339043.

[111] B.-J. Li, S.-L. Tian, Z. Fang, Z.-J. Shi, 'Multiple C $\nabla H$ Activations To Construct Biologically Active Molecules in a Process Completely Free of Organohalogen and Organometallic Components', Angew. Chem., Int. Ed. 2008, 47, 1115-1118.

[112] L. Ackermann, P. Novák, R. Vicente, N. Hofmann, 'Ruthenium-Catalyzed Regioselective Direct Alkylation of Arenes with Unactivated Alkyl Halides through C-H Bond Cleavage', Angew. Chem., Int. Ed. 2009, 48, 6045-6048. 


\section{Entry for the Table of Contents}

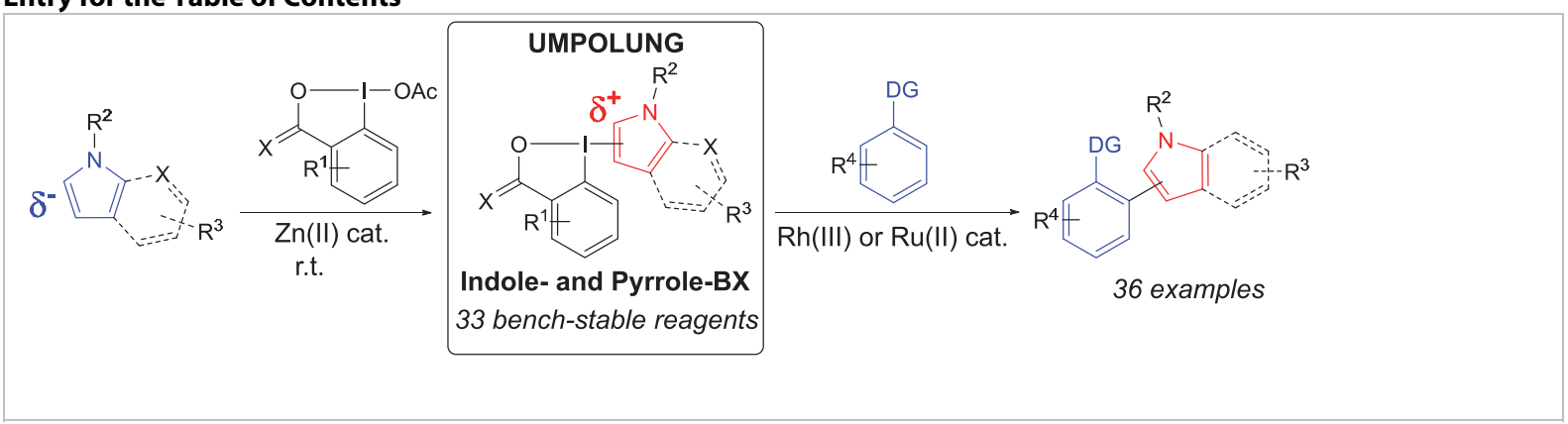


Supplementary Materials for

Bench-Stable Electrophilic Indole and Pyrrole Reagents:

Serendipitous Discovery and Use in C-H Functionalization

Paola Caramenti and Jerome Waser 


\section{Supporting Information}

\section{Table of contents}

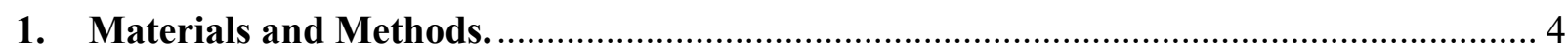

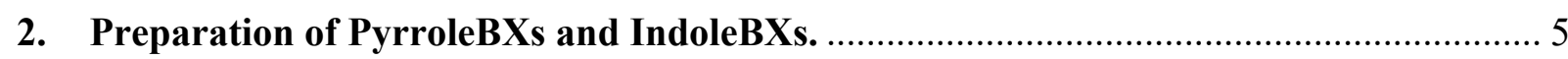

2.1 Preparation of Hypervalent Iodine Precursors. ............................................................ 5

2.2 Preparation of the Starting Materials for the Synthesis of PyrroleBXs and IndoleBXs.

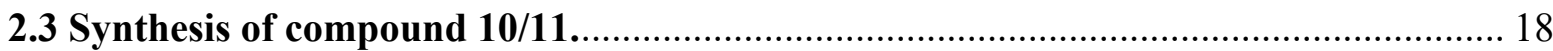

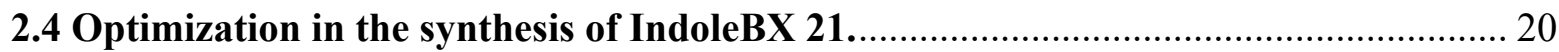

2.5 Preparation of PyrroleBX and IndoleBX Reagents. .................................................. 21

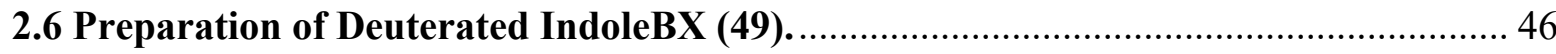

2.7 Preparation of $\boldsymbol{\beta}$-Phenyliodonioindole Tetrafluoroborate (53). ................................. 47

3. Rh-Catalyzed C-H Indolization of Arenes via C-H activation........................................ 49

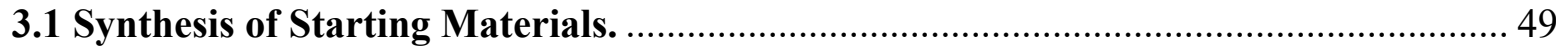

3.2 Optimization of the Rh-Catalyzed Indolization of Arenes via $\mathrm{C}$-H activation. ........... 52

3.3 Control experiments for the Indolization of Arenes via $\mathrm{C}-\mathrm{H}$ activation..................... 55

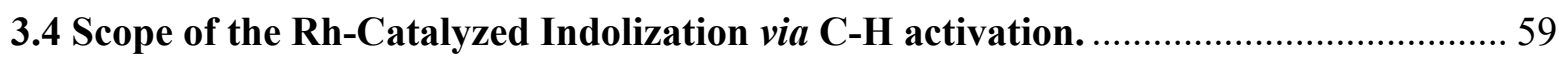

4. Ru-Catalyzed C-H Indolization of Arenes via C-H activation........................................ 76

4.1 Preparation of starting materials for Ru-Catalyzed C-H activation.......................... 76

4.2 Optimization of the Ru-Catalyzed Indolization of Arenes via C-H activation........... 82

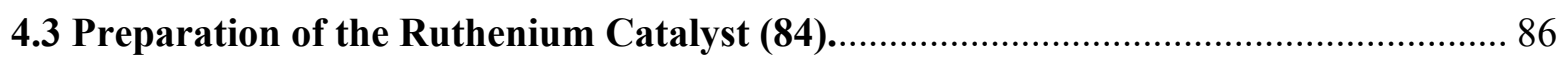

4.4 Scope of the Ru-Catalyzed Indolization via C-H activation..................................... 87

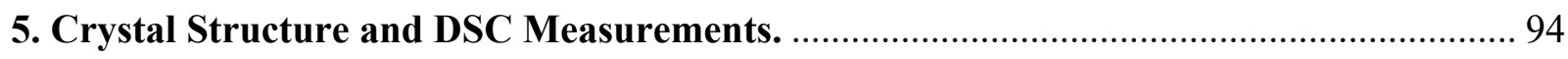

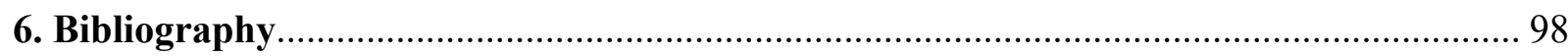

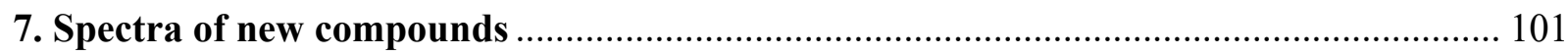




\section{Materials and Methods.}

All reactions were carried out in oven dried glassware under an atmosphere of nitrogen, unless stated otherwise. For quantitative flash chromatography, technical grade solvents were used. For flash chromatography for analysis, HPLC grade solvents from Sigma-Aldrich were used. THF, $\mathrm{Et}_{2} \mathrm{O}, \mathrm{CH}_{3} \mathrm{CN}$, toluene, hexane and $\mathrm{CH}_{2} \mathrm{Cl}_{2}$ were dried by passage over activated alumina under nitrogen atmosphere $\left(\mathrm{H}_{2} \mathrm{O}\right.$ content $<10 \mathrm{ppm}$, Karl-Fischer titration). The solvents were degassed through Freeze-Pump-Thaw method when mentioned. All chemicals were purchased from Acros, Aldrich, Fluka, VWR, Aplichem, or Merck and used as such unless otherwise stated. Chromatographic purification was performed as flash chromatography using Macherey-Nagel silica 40-63, $60 \AA$, with the solvents indicated as eluent under 0.1-0.5 bar pressure. TLC was performed on Merck silica gel $60 \mathrm{~F}_{254}$ TLC glass plates or aluminium plates and visualized with UV light, permanganate stain, CAN stain, or Anisaldehyde stain. Melting points were measured on a Büchi B-540 melting point apparatus using open glass capillaries, the data is uncorrected. ${ }^{1} \mathrm{H}-$ NMR spectra were recorded on a Brucker DPX-400 $400 \mathrm{MHz}$ spectrometer in $\mathrm{CDCl}_{3}, \mathrm{DMSO}-d_{6}$ $\mathrm{CD}_{3} \mathrm{OD}, \mathrm{C}_{6} \mathrm{D}_{6}$ and $\mathrm{CD}_{2} \mathrm{Cl}_{2}$, all signals are reported in ppm with the internal chloroform signal at $7.26 \mathrm{ppm}$, the internal DMSO signal at $2.50 \mathrm{ppm}$ the internal methanol signal at $3.30 \mathrm{ppm}$, the internal dichloromethane signal at $5.30 \mathrm{ppm}$ as standard. The data is being reported as ( $\mathrm{s}=$ singlet, $\mathrm{d}=$ doublet, $\mathrm{t}$ = triplet, $\mathrm{q}=$ quadruplet, $\mathrm{q} \mathrm{i}=$ quintet, $\mathrm{m}=$ multiplet or unresolved, $\mathrm{br}=$ broad signal, app = apparent, coupling constant(s) in $\mathrm{Hz}$, integration, interpretation). ${ }^{13} \mathrm{C}-\mathrm{NMR}$ spectra were recorded with ${ }^{1} \mathrm{H}$-decoupling on a Brucker DPX-400 $100 \mathrm{MHz}$ spectrometer in $\mathrm{CDCl}_{3}, \mathrm{DMSO}-d_{6}$, $\mathrm{CD}_{3} \mathrm{OD}$ or $\mathrm{CD}_{2} \mathrm{Cl}_{2}$, all signals are reported in ppm with the internal chloroform signal at $77.0 \mathrm{ppm}$, the internal DMSO signal at $39.5 \mathrm{ppm}$, the internal methanol signal at $49.0 \mathrm{ppm}$ and the internal dichloromethane signal at $54.0 \mathrm{ppm}$ as standard. Infrared spectra were recorded on a JASCO FTIR B4100 spectrophotometer with an ATR PRO410-S and a ZnSe prisma and are reported as $\mathrm{cm}^{-1}$ ( $\mathrm{w}=$ weak, $\mathrm{m}=$ medium, $\mathrm{s}=$ strong, $\mathrm{br}=$ broad). High resolution mass spectrometric measurements were performed by the mass spectrometry service of ISIC at the EPFL on a MICROMASS (ESI) Q-TOF Ultima API. 


\section{Preparation of PyrroleBXs and IndoleBXs.}

The synthesis of the precursors for HeterocyclicBX reagents 21, 25, 26-37, 43-46 and their starting materials had been already described before. ${ }^{[1,2]}$ The procedures here reported are taken from the cited publications to facilitate reproduction of the results by having all the data in the same file.

\subsection{Preparation of Hypervalent Iodine Precursors.}

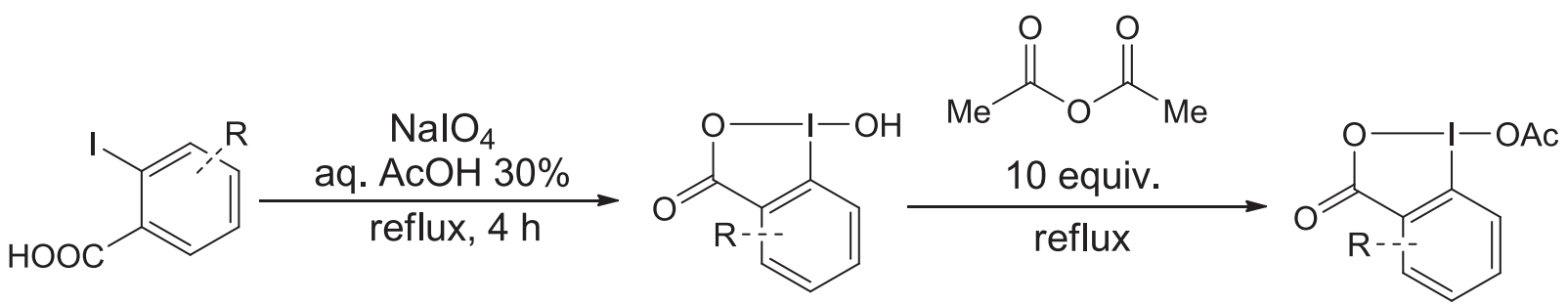

Following a reported procedure, ${ }^{[1]} \mathrm{NaIO}_{4}(7.24 \mathrm{~g}, 33.8 \mathrm{mmol}, 1.05$ equiv) and 2-iodobenzoic acids ( $8.00 \mathrm{~g}, 32.2 \mathrm{mmol}, 1.00$ equiv) were suspended in 30\% (v/v) aq. AcOH (48 mL). The mixture was vigorously stirred and refluxed for $4 \mathrm{~h}$. The reaction mixture was then diluted with cold water (180 $\mathrm{mL}$ ) and allowed to cool to room temperature, protecting it from light. After $1 \mathrm{~h}$, the crude product was collected by filtration, washed on the filter with ice water $(3 \times 20 \mathrm{~mL})$ and acetone $(3 \times 20$ $\mathrm{mL}$ ), and air-dried in the dark to give the pure hydroxylated intermediates.

Following a reported procedure, ${ }^{[2]}$ hydroxylated intermediates $(39.1 \mathrm{mmol}, 1.00$ equiv.) were suspended in acetic anhydride $(35 \mathrm{~mL})$ and heated to reflux for 30 minutes. The resulting clear, slightly yellow solution was slowly let to warm up to room temperature and then cooled to $0{ }^{\circ} \mathrm{C}$ for 30 minutes. The white suspension was filtered and the filtrate was again cooled to $0{ }^{\circ} \mathrm{C}$ for 30 minutes. The suspension was once again filtered and the combined two batches of solid product were washed with hexane $(2 \times 20 \mathrm{~mL})$ and dried in vacuo to afford products 20, 95-97. 


\section{1-Acetoxy-1,2-benziodoxol-3-(1H)-one 20}<smiles>CC(=O)OI1OC(=O)c2ccccc21</smiles>

1-Acetoxy-1,2-benziodoxol-3-(1H)-one 20 (10.8 g, $35.3 \mathrm{mmol}, 90 \%)$ as a white solid. ${ }^{1} \mathbf{H}$ NMR $\left(\mathrm{CDCl}_{3}, 400 \mathrm{MHz}\right) \delta 8.24(\mathrm{dd}, J=7.6,1.6 \mathrm{~Hz}, 1 \mathrm{H}, \mathrm{Ar} H), 8.00$ (dd, $J=8.3,1.0 \mathrm{~Hz}, 1 \mathrm{H}, \operatorname{Ar} H), 7.92(\mathrm{ddd}, J=8.4,7.2,1.6 \mathrm{~Hz}, 1 \mathrm{H}, \operatorname{Ar} H), 7.71$ $(\operatorname{td}, J=7.3,1.1 \mathrm{~Hz}, 1 \mathrm{H}, \mathrm{Ar} H), 2.25\left(\mathrm{~s}, 3 \mathrm{H}, \mathrm{COCH}_{3}\right) .{ }^{13} \mathbf{C} \mathbf{N M R}\left(\mathrm{CDCl}_{3}, 100 \mathrm{MHz}\right) \delta 176.5,168.2$, 136.2, 133.3, 131.4, 129.4, 129.1, 118.4, 20.4. NMR values are in accordance with the data reported in literature. ${ }^{[3]}$

\section{5,6-Dimethoxy-3-oxo-1 $\lambda_{3}$-benzo[d] $[1,2]$ iodaoxol-1(3H)-yl acetate (95)}<smiles>COc1cc2c(cc1OC)I(OC(C)=O)OC2=O</smiles>

5,6-Dimethoxy-3-oxo-1 $\lambda_{3}$-benzo[d][1,2]iodaoxol-1(3H)-yl acetate 95 (12.8 g, 35.0 mmol, 89\%) was obtained as a white solid. ${ }^{1} \mathbf{H}$ NMR $\left(\mathrm{CDCl}_{3}, 400\right.$ MHz) $\delta 7.63(\mathrm{~s}, 1 \mathrm{H}, \mathrm{ArH}), 7.36$ (s, 1H, ArH), 4.02 (s, 3H, OMe), 4.00 (s, $3 \mathrm{H}, \mathrm{OMe}), 2.24(\mathrm{~s}, 3 \mathrm{H}, \mathrm{O} A c) .{ }^{13} \mathbf{C}$ NMR $\left(\mathrm{CDCl}_{3}, 100 \mathrm{MHz}\right) \delta 176.4,168.4$, 155.9, 152.0, 121.8, 113.6, 110.0, 109.0, 56.6, 20.4. NMR values are in accordance with the data reported in literature. ${ }^{[4]}$

\section{4-Fluoro-3-oxo-1 $\lambda_{3}$-benzo $[d][1,2]$ iodaoxol-1(3H)-yl acetate (96)}<smiles>CC(=O)OI1C(=O)OC1=O</smiles>

4-Fluoro-3-oxo-1 $\lambda_{3}$-benzo[d][1,2]iodaoxol-1(3H)-yl acetate 96 (9.62 g, 29.7 mmol, 76\%) was obtained as a white solid. ${ }^{1} \mathbf{H}$ NMR (400 MHz, DMSO- $\left.d_{6}\right) \delta$ $7.94(\mathrm{td}, J=8.2,4.7 \mathrm{~Hz}, 1 \mathrm{H}, \operatorname{Ar} H), 7.73$ (d, $J=8.2 \mathrm{~Hz}, 1 \mathrm{H}, \operatorname{Ar} H), 7.62$ (dd, $J$ $=10.3,8.2 \mathrm{~Hz}, 1 \mathrm{H}, \mathrm{Ar} H), 2.24(\mathrm{~s}, 3 \mathrm{H}, \mathrm{O} A c) .{ }^{1} \mathrm{H}-\mathrm{NMR}$ values are in accordance with the data reported in literature. ${ }^{[4]}$

\section{1-Acetoxy-5-nitro-1,2-benziodoxol-3(1H)-one ANBX (97)}

1-Acetoxy-5-nitro-1,2-benziodoxol-3(1H)-one 97 (8.71 g, 24.8 mmol, 64\%) was obtained as a white solid. ${ }^{1} \mathbf{H}$ NMR $\left(400 \mathrm{MHz}, \mathrm{DMSO}-d_{6}\right) \delta 8.71(\mathrm{dt}, J$ $=8.9,2.7 \mathrm{~Hz}, 1 \mathrm{H}, \operatorname{Ar} H), 8.62-8.54(\mathrm{~m}, 1 \mathrm{H}, \operatorname{Ar} H), 8.12(\mathrm{dd}, J=23.8,8.8 \mathrm{~Hz}$, $1 \mathrm{H}, \mathrm{Ar} H), 1.90(\mathrm{~s}, 3 \mathrm{H}, \mathrm{O} A c) .{ }^{13} \mathbf{C}$ NMR (101 MHz, DMSO- $\left.d_{6}\right) \delta 172.0,166.0$, $149.8,133.5,128.3,128.2,127.8,124.9,21.1$. NMR values are in accordance with the data reported in literature. ${ }^{[5]}$ 


\section{1-Chloro-1,3-dihydro-3,3-bis(trifluoromethyl)-1,2-benziodoxole (100)}

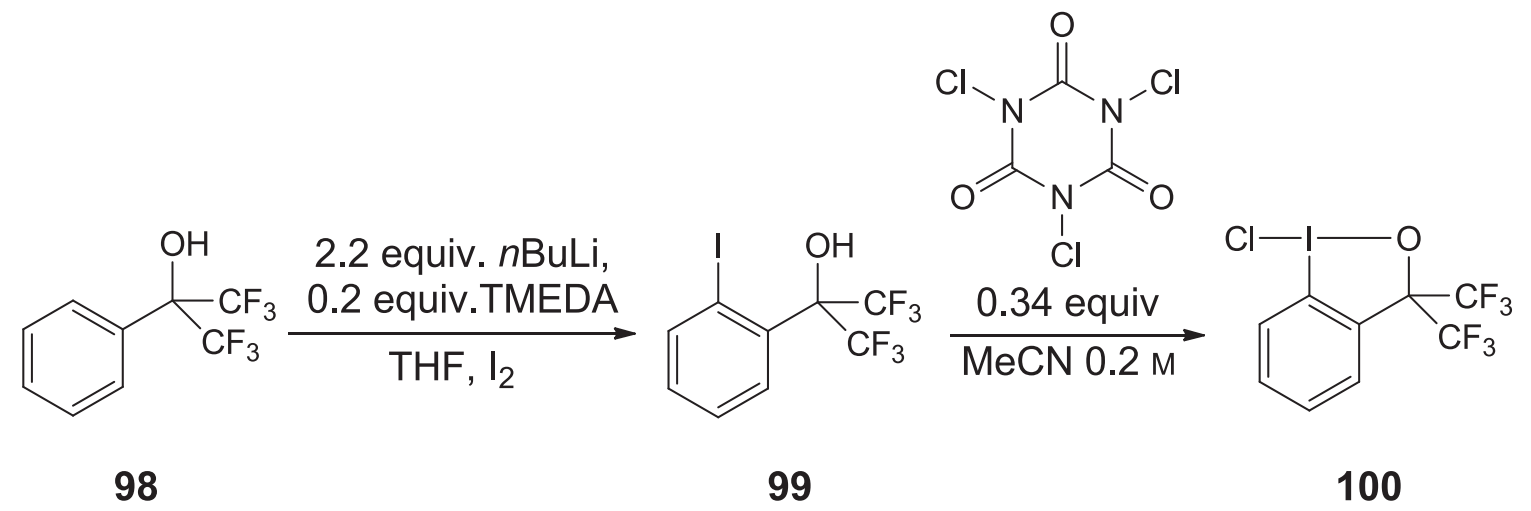

Following a reported procedure, TMEDA (distilled over KOH) $(1.26 \mathrm{~mL}, 8.20 \mathrm{mmol}, 0.200$ equiv) was added to a solution of $n \mathrm{BuLi}(2.5 \mathrm{M}$ in hexanes, $36.6 \mathrm{~mL}, 91.6 \mathrm{mmol}, 2.20$ equiv). After 15 min, the cloudy solution was cooled to $0{ }^{\circ} \mathrm{C}$ and $98(7.00 \mathrm{~mL}, 42.0 \mathrm{mmol}, 1$ equiv) in THF $(6 \mathrm{~mL})$ was added dropwise. The reaction was stirred $30 \mathrm{~min}$ at $0{ }^{\circ} \mathrm{C}$ and then at $\mathrm{RT}$ overnight. $\mathrm{I}_{2}(11.2 \mathrm{~g}$, $44.0 \mathrm{mmol}, 1.06$ equiv) was then added portionwise at $0{ }^{\circ} \mathrm{C}$ and the mixture stirred at $0{ }^{\circ} \mathrm{C}$ for 30 min and $4 \mathrm{~h}$ at $\mathrm{RT}$. The reaction was quenched with saturated $\mathrm{NH}_{4} \mathrm{Cl} . \mathrm{Et}_{2} \mathrm{O}(100 \mathrm{~mL})$ was added and the layers were separated. The aqueous layer was then extracted twice with $\mathrm{Et}_{2} \mathrm{O}(3 \times 50 \mathrm{~mL})$. The organic layers were combined, washed twice with saturated $\mathrm{NaS}_{2} \mathrm{O}_{3}(2 \times 50 \mathrm{~mL})$, dried over $\mathrm{MgSO}_{4}$, filtered and concentrated under reduced pressure to afford $15.6 \mathrm{~g}$ of crude 99 as an brown oil which was used without further purification. The crude oil was dissolved in $\mathrm{MeCN}(40 \mathrm{~mL})$ in the dark under air. Trichloroisocyanuric acid (3.42 g, $14.3 \mathrm{mmol}, 0.340$ equiv.) was then added portionwise at r.t. After $30 \mathrm{~min}$, the resulting suspension was filtered to afford $\mathbf{1 0 0}(7.30 \mathrm{~g}, 18.1$ mmol, 43\%) as a yellow solid. The mother liquors were carefully reduced to one third and filtered to afford more 27 (8.85 g, $21.9 \mathrm{mmol}, 52.1 \%$ yield) as a yellow solid. Mp: $167-169^{\circ} \mathrm{C} .{ }^{1} \mathbf{H}$ NMR $\left(400 \mathrm{MHz}, \mathrm{CDCl}_{3}\right) \delta 8.09(\mathrm{~d}, 1 \mathrm{H}, \mathrm{J}=8.4 \mathrm{~Hz}, \mathrm{Ar} H), 7.85(\mathrm{~m}, 1 \mathrm{H}, \mathrm{ArH}), 7.73(\mathrm{~m}, 2 \mathrm{H}, \mathrm{ArH}) .{ }^{13} \mathrm{C}$ NMR $\left(101 \mathrm{MHz}, \mathrm{CDCl}_{3}\right) \delta 133.8,132.1,131.6,129.7,128.5,122.8$ (q, $\left.289 \mathrm{~Hz}\right), 113.4,84.8$. The melting point and the ${ }^{1} \mathrm{H}$ NMR correspond to the reported values. ${ }^{[6]}$ 
1-Acetoxy-1,3-dihydro-3,3-bis(trifluoromethyl)-1,2-benziodoxole (18)

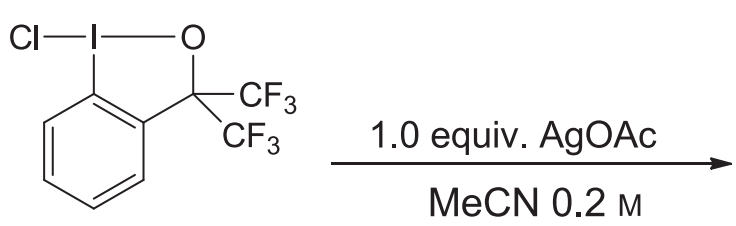

100<smiles>CC(=O)OI1OC(C(F)(F)F)(C(F)(F)F)c2ccccc21</smiles>

18

1-Chloro-1,3,-dihydro-3,3-bis(trifluoromethyl)-1,2-benziodoxole 100 (8.85 g, $21.9 \mathrm{mmol})$ and AgOAc (3.65 g, 21.9 mmol, 1 equiv.) were suspended in MeCN (109 mL, 0.2 M). After being stirred overnight in the dark, $\mathrm{AgCl}$ precipitated and was filtered off. The residue was washed with $\mathrm{MeCN}$. The solvent was removed in vacuo to give $\mathbf{1 8}(9.37 \mathrm{~g}, 21.9 \mathrm{mmol}, 100 \%)$ as a white solid. ${ }^{1}$ H NMR (300 MHz, $\left.\mathrm{CDCl}_{3}\right) \delta 7.93(\mathrm{~d}, J=8.4 \mathrm{~Hz}, 1 \mathrm{H}, \mathrm{ArH}), 7.61-7.79$ (m, 3H, ArH), 2.18 (s, $\left.3 \mathrm{H}, \mathrm{CH}_{3}\right)$. The NMR values correspond to the reported ones. ${ }^{[3]}$

\section{1-Azido-3,3-bis(trifluoromethyl)-3-(1H)-1,2-benziodoxole (8).}

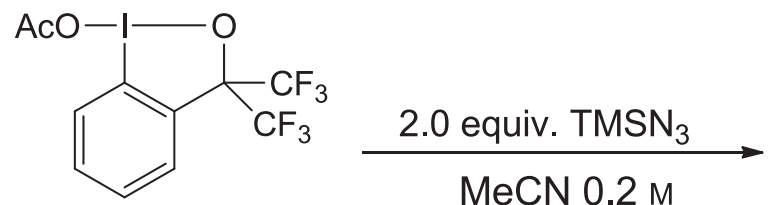

18<smiles>NI1OC(C(F)(F)F)(C(F)(F)F)c2ccccc21</smiles>

8

To a stirred mixture of 1-hydroxy-3,3-bis(trifluoromethyl)-3-(1H)-1,2- benziodoxole 18 (1.00 g, $2.60 \mathrm{mmol})$ in dry $\mathrm{CH}_{3} \mathrm{CN}(20 \mathrm{~mL})$ was added trimethylsilylazide $(0.700 \mathrm{~mL}, 5.20 \mathrm{mmol})$ under nitrogen at room temperature. The reaction mixture was stirred for $18 \mathrm{~h}$, and then the resulting yellow solution was evaporated in vacuum to give 8 as a pale crystalline solid ( $890 \mathrm{mg}$, yield 0.490 $\mathrm{g}(92 \%) ; \mathrm{mp} 147-150{ }^{\circ} \mathrm{C}$ (from $\left.\mathrm{CH}_{3} \mathrm{CN}\right)$; IR $v 3076,2048 .{ }^{1} \mathbf{H} \mathbf{N M R}\left(\mathrm{CDCl}_{3}: \mathrm{CD}_{3} \mathrm{CN} 10: 1\right) \delta$ 7.89$7.66(\mathrm{~m}, 4 \mathrm{H}, \mathrm{Ar} H)$. The IR and NMR values correspond to the reported ones. ${ }^{[7]}$ 


\subsection{Preparation of the Starting Materials for the Synthesis of PyrroleBXs and IndoleBXs.}

In this section, only the synthesis of non-commercially available indole compounds is reported. The synthesis of the precursors for HeterocyclicBX reagents 11, 16, 17, 21, 23, 26-48 had been already described by our group before. The procedures reported here are taken from the cited publications to facilitate reproduction of the results by having all the data in the same file. ${ }^{[8,9]}$

\section{2-(1-Methoxypent-3-yn-1-yl)-1-methyl-1H-pyrrole (105)}

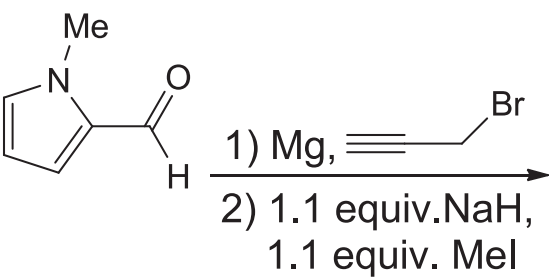

103

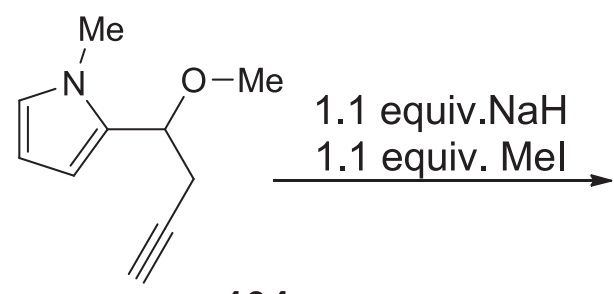

104

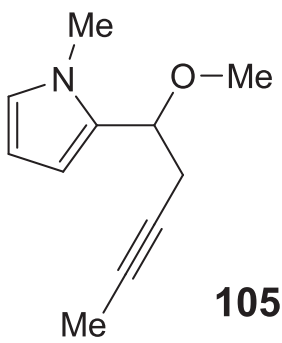

105

A $50 \mathrm{~mL}$ two-necked flask was charged with $\mathrm{Mg}$ (321 mg, $13.2 \mathrm{mmol}, 1.32$ equiv), $\mathrm{HgCl}_{2}$ (2.7 mg, $0.10 \mathrm{mmol}, 0.01$ equiv) and dry diethyl ether $(30 \mathrm{~mL})$, then propargyl bromide was added dropwise ( $2.86 \mathrm{~g}, 12.0 \mathrm{mmol}, 1.20$ equiv). When the solution became homogeneous, 103 (1.09 g, $10.0 \mathrm{mmol}$, 1.00 equiv) was added dropwise. The reaction was quenched with sat $\mathrm{NH}_{4} \mathrm{Cl}$ solution $(30 \mathrm{~mL})$ when TLC (Pentane/EtOAc: 5/1) indicated that the aldehyde was completely consumed after 4 hours. The aqueous and organic layers were separated; the aqueous layer was extracted with diethyl ether $(3 \times 20 \mathrm{~mL})$. The combined organic layers were dried over $\mathrm{MgSO}_{4}$ and concentrated under vaccum to obtain $1.34 \mathrm{~g}$ crude product as brown oil. The crude product was used for the next step directly without further purification. Crude propargylic alcohol ( $1.34 \mathrm{~g}, 8.98 \mathrm{mmol}, 0.89$ equiv) in THF (18 mL) was added into a suspension of $\mathrm{NaH}(237 \mathrm{mg}, 9.88 \mathrm{mmol}, 0.98$ equiv) in THF (18 $\mathrm{mL}) .15$ minutes later, MeI (1.40 g, $9.88 \mathrm{mmol}, 1.10$ equiv) was added into the mixture. The reaction was quenched with sat $\mathrm{NH}_{4} \mathrm{Cl}$ after $4 \mathrm{~h}$. The aqueous and organic layers were separated and the aqueous layer was extracted with ether $(3 \times 10 \mathrm{~mL})$. After drying over MgSO4, filtrating and concentrating under vacuum, the crude product was purified by column chromatography (Pentane:EtOAc $\left.=15: 1,1 \% \mathrm{Et}_{3} \mathrm{~N}\right)$ to afford 104 as brown oil $(1.00 \mathrm{~g}, 6.13 \mathrm{mmol}, 61 \%$ over two 
steps). Rf : 0.6 (Pentane:EtOAc 25:1). ${ }^{1} \mathbf{H}$ NMR (400 MHz, $\left.\mathrm{CDCl}_{3}\right) \delta 6.62(\mathrm{~m}, 1 \mathrm{H}, \mathrm{ArH}), 6.18$ $(\mathrm{dd}, 1 \mathrm{H}, \mathrm{J}=3.6,1.8 \mathrm{~Hz}, \mathrm{ArH}), 6.10(\mathrm{dd}, 1 \mathrm{H}, \mathrm{J}=3.6,2.7 \mathrm{~Hz}, \mathrm{ArH}), 4.58(\mathrm{t}, 1 \mathrm{H}, \mathrm{J}=6.9 \mathrm{~Hz}, \mathrm{CHO}$ ), $3.68\left(\mathrm{~s}, 3 \mathrm{H}, \mathrm{NCH}_{3}\right), 3.27$ (s, $\left.3 \mathrm{H}, \mathrm{OCH}_{3}\right), 2.79$ (ddd, $\left.2 \mathrm{H}, \mathrm{J}=16.8,6.5,2.7 \mathrm{~Hz}, \mathrm{CH}_{2}\right), 2.05$ (t, $1 \mathrm{H}$, $\mathrm{J}=2.7 \mathrm{~Hz}, \mathrm{CH}) .{ }^{13} \mathbf{C} \mathbf{N M R}\left(101 \mathrm{MHz}, \mathrm{CDCl}_{3}\right) \delta 129.9,123.3,108.5,106.4,80.7,73.9,69.8,54.7$, $34.0,24.0$.

$448 \mathrm{mg}$ of crude 104 (3.00 mmol), $\mathrm{NaH}$ (144 mg, $6.00 \mathrm{mmol}, 2$ equiv) and $\mathrm{CH}_{3} \mathrm{I}(1.06 \mathrm{~g}, 7.50$ mmol, 2.5 equiv) were used for the methylation with the same method as before. 105 was obtained as yellow oil (384 mg, $1.83 \mathrm{mmol}, 48 \%$ over two steps). Rf: 0.5 (Pentane:EtOAc $=15: 1) .{ }^{1} \mathbf{H}$ NMR $\left(400 \mathrm{MHz}, \mathrm{CDCl}_{3}\right) \delta 6.59(\mathrm{~m}, 1 \mathrm{H}, \mathrm{ArH}), 6.15(\mathrm{dd}, 1 \mathrm{H}, \mathrm{J}=3.6,1.8 \mathrm{~Hz}, \mathrm{ArH}), 6.08(\mathrm{dd}, 1 \mathrm{H}, \mathrm{J}=$ 3.6, 2.7 Hz, ArH), 4.50 (m, $\left.1 \mathrm{H}, \mathrm{CHOCH}_{3}\right), 3.66$ (s, $\left.3 \mathrm{H}, \mathrm{NCH}\right), 3.25$ (s, $\left.3 \mathrm{H}, \mathrm{OCH}_{3}\right), 2.72$ (m, 2 $\left.\mathrm{H}, \mathrm{CH}_{2}\right), 1.79\left(\mathrm{t}, 3 \mathrm{H}, \mathrm{J}=2.6 \mathrm{~Hz}, \mathrm{CH}_{3}\right) .{ }^{13} \mathbf{C} \mathbf{N M R}\left(101 \mathrm{MHz}, \mathrm{CDCl}_{3}\right) \delta 130.4,123.1,108.2,106.4$, $76.9,75.4,74.4,54.6,33.9,24.3,3.3$.

\section{General Procedure GP1 for the N-Methylation of Indoles.}
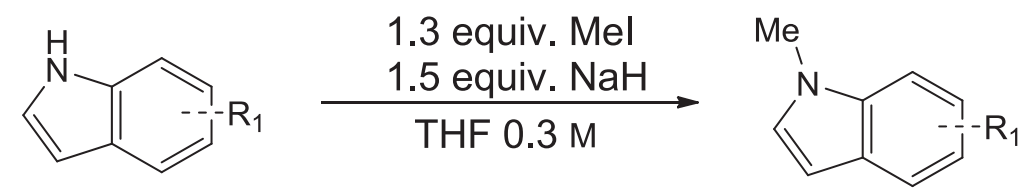

The corresponding indole (1.00 - $5.00 \mathrm{mmol}, 1.00$ equiv.) was dissolved in dry THF (0.3 M). Sodium hydride ( $60 \%$ suspension in mineral oil; 1.50 equiv.) was slowly added under $\mathrm{N}_{2}$ flow at 0 ${ }^{\circ} \mathrm{C}$. After being stirred at $0{ }^{\circ} \mathrm{C}$ for $15 \mathrm{~min}$, the reaction mixture was allowed to warm to r.t for 1.5 h. It was then cooled back to $0{ }^{\circ} \mathrm{C}$ and methyl iodide (1.30 equiv.) was added. The mixture was warmed to r.t. and stirred overnight. After cooling again to $0^{\circ} \mathrm{C}$, the reaction was quenched with water $(10 \mathrm{~mL})$, extracted with $\mathrm{Et}_{2} \mathrm{O}(3 \times 10 \mathrm{~mL})$, the combined organic layers were dried over $\mathrm{MgSO}_{4}$, and the solvent removed under reduced pressure. The resulting crude product was purified via flash column chromatography (Pentane:EtOAc 9:1-4:1), to give the desired N-methylated indole. 
<smiles>Cc1cc2ccccc2n1C</smiles>

106<smiles>COc1ccc2c(ccn2C)c1</smiles>

107<smiles>Cn1ccc2cc(F)ccc21</smiles>

108<smiles>Cn1ccc2cc(Cl)ccc21</smiles>

109<smiles>Cn1ccc2cc(I)ccc21</smiles>

110

\section{1,2-Dimethyl-1H-indole (106)}<smiles>Cc1cc2ccccc2n1C</smiles>

106

Starting from commercially available 2 -methylindole $(656 \mathrm{mg}, 5.00 \mathrm{mmol})$, 1,2-dimethyl-1H-indole 106 (683 mg, $4.70 \mathrm{mmol}$, 94\% yield) was obtained as an off-white solid. IR $v$ (neat) 3050 (w), 3020 (w), 2970 (m), 1610 (w), 1400 (s), 1340 (m), 1240 (m), 930 (m), 910 (w), 780 (m), 750 (m), 730 (s). ${ }^{1}$ H NMR $\left(400 \mathrm{MHz} \mathrm{CDCl}_{3}\right) \delta 7.69(\mathrm{~d}, J=7.8 \mathrm{~Hz}, 1 \mathrm{H}, \mathrm{Ar} H), 7.41(\mathrm{dd}, J=8.1,1.0 \mathrm{~Hz}, \mathrm{Ar} H), 7.32(\mathrm{~m}, 1 \mathrm{H}$, $\operatorname{Ar} H), 7.24$ (ddd, $J=8.0,7.0,1.1 \mathrm{~Hz}, 1 \mathrm{H}, \mathrm{Ar} H), 6.42\left(\mathrm{~s}, 1 \mathrm{H}, \mathrm{NC}\left(\mathrm{CH}_{3}\right) \mathrm{CH}\right), 3.79\left(\mathrm{~s}, 3 \mathrm{H}, \mathrm{NCH}_{3}\right)$, $2.57\left(\mathrm{~d}, J=1.0 \mathrm{~Hz}, 3 \mathrm{H}, \mathrm{NCCH}_{3}\right) .{ }^{13} \mathbf{C} \mathbf{N M R}\left(125 \mathrm{MHz}, \mathrm{CDCl}_{3}\right) \delta 138.1,136.9,128.1,120.6$, $119.8,119.4,108.8,99.7,29.5,12.9 .{ }^{1} \mathrm{H}$ NMR values are in accordance with the data reported in literature. ${ }^{[10]}$

\section{5-Methoxy-1-methyl-1H-indole (107)}

Starting from commercially available 5-methoxy- $1 H$-indole $(736 \mathrm{mg}, 5.00$ mmol), 5-methoxy-1-methyl-1H-indole 107 (730 mg, $4.53 \mathrm{mmol}, 91 \%$ yield) was obtained as a colorless crystalline solid. IR $v 2952$ (w), 2918 (w), 2834 (w), 1622 (m), 1608 (w), 1577 (w), 1496 (s), 1459 (w), 1450 (m), 1449 (m), 1421 (s), 1347 (w), 1293 (w), 1243 (s), 1191 (m), 1152 (s), 1102 (w), 1026 (m), 942 (w), 855 (m), 845 (w), 805 (s). ${ }^{1} \mathbf{H}$ NMR (400 MHz, $\left.\mathrm{CDCl}_{3}\right) \delta 7.30$ (d, $\left.1 \mathrm{H}, J=8.5 \mathrm{~Hz}, \mathrm{Ar} H\right) 7.13$ (s, 1H, ArH), 
7.05 (s, $1 \mathrm{H}, \operatorname{Ar} H), 6.92(\mathrm{~d}, 1 \mathrm{H}, J=8.8 \mathrm{~Hz}, \operatorname{Ar} H), 6.43$ (d, 1H, J=1.0 Hz, ArH), 3.90 (s, 3H, NMe), 3.80 (s, 3H, OMe $).{ }^{13} \mathrm{C}$ NMR $\left(101 \mathrm{MHz}, \mathrm{CDCl}_{3}\right) \delta 154.0,132.2,129.3,128.8,111.9,109.9,102.5$, $100.4,55.9,33.0$.

\section{5-Fluoro-1-methyl-1H-indole (108)}<smiles>Cn1ccc2cc(F)ccc21</smiles>

108

Starting from commercially available 5-fluoro- $1 H$-indole $(676 \mathrm{mg}, 5.00 \mathrm{mmol})$, 5-fluoro-1-methyl-1H-indole 108 (683 $\mathrm{mg}, 4.58 \mathrm{mmol}, 92 \%$ yield) was obtained as a colorless solid. IR 3104 (w), 2946 (w), 2922 (w), 2907 (w), 2887 (w), $2362(\mathrm{w}), 2343(\mathrm{w}), 1626(\mathrm{w}), 1576(\mathrm{w}), 1514(\mathrm{~m}), 1492$ (s), 1449 (m), 1423 (m), 1340 (m), 1283 (m), 1238 (s), 1228 (s), 1140 (m), 1129 (m), 1122 (m), 1100 (m), 1081 (m), 1013 (w), 949 (m), 859 (m), 811 (s). ${ }^{1} \mathbf{H}$ NMR (400 MHz, $\left.\mathrm{CDCl}_{3}\right) \delta 7.31$ (dd, $J=9.7,2.4 \mathrm{~Hz}$, $1 \mathrm{H}, \operatorname{Ar} H), 7.26(\mathrm{~m}, 1 \mathrm{H}, \operatorname{Ar} H), 7.12(\mathrm{~d}, J=3.1 \mathrm{~Hz}, 1 \mathrm{H}, \operatorname{Ar} H), 7.01(\mathrm{dt}, J=9.1,2 \mathrm{~Hz}, 1 \mathrm{H}, \operatorname{Ar} H)$, $6.48(\mathrm{dd}, J=3.1,0.7 \mathrm{~Hz}, 1 \mathrm{H}, \mathrm{Ar} H) .3 .81(\mathrm{~s}, 3 \mathrm{H}, \mathrm{NCH} 3){ }^{13} \mathbf{C}$ NMR $\left(101 \mathrm{MHz}, \mathrm{CDCl}_{3}\right) \delta 158.0(\mathrm{~d}$, $\left.J-\mathrm{F}_{6}=232 \mathrm{~Hz}\right), 133.4,130.4,128.7\left(\mathrm{~d}, J-\mathrm{F}_{6}=10 \mathrm{~Hz}\right), 109.9\left(\mathrm{~d}, J-\mathrm{F}_{6}=15 \mathrm{~Hz}\right), 109.8,105.5(\mathrm{~d}, J-$ $\left.\mathrm{F}_{6}=23 \mathrm{~Hz}\right), 100.8\left(\mathrm{~d}, J-\mathrm{F}_{6}=5.0 \mathrm{~Hz}\right), 33.1$.

\section{5-Chloro-1-methyl-1H-indole (109)}

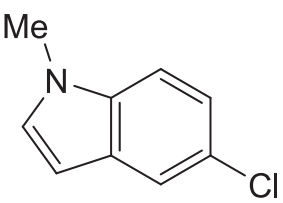

109

Starting from commercially available 5-chloro- $1 H$-indole $(758 \mathrm{mg}, 5.00$ mmol), 5-chloro-1-methyl-1 $H$-indole 109 ( $800 \mathrm{mg}, 4.83 \mathrm{mmol}, 97 \%$ yield) was obtained as a colorless solid. IR $v 3102$ (w), 2943 (w), 2913 (w), 2881 (w), 2817 (w), 1567 (w), 1513 (m), 1475 (s), 1441 (m), 1421 (s), 1379 (w), 1331

(m), 1278 (s), 1241 (s), 1199 (m), 1146 (m), 1106 (w), 1082 (m), 1063 (s), 1009 (m), 909 (m), 870 (m), 869 (m). ${ }^{1} \mathbf{H}$ NMR $\left(400 \mathrm{MHz}, \mathrm{CDCl}_{3}\right) \delta 7.64(\mathrm{~d}, J=2.1 \mathrm{~Hz}, 1 \mathrm{H}, \mathrm{ArH}), 7.30-7.19(\mathrm{~m}, 2 \mathrm{H}$, $\operatorname{Ar} H), 7.10(\mathrm{~d}, J=3.1 \mathrm{~Hz}, 1 \mathrm{H}, \mathrm{Ar} H), 6.47(\mathrm{dd}, J=3.1,0.7 \mathrm{~Hz}, 1 \mathrm{H}, \mathrm{Ar} H), 3.80\left(\mathrm{~s}, 3 \mathrm{H}, \mathrm{NCH}_{3}\right) .{ }^{13} \mathbf{C}$ NMR $\left(101 \mathrm{MHz}, \mathrm{CDCl}_{3}\right) \delta 135.1,130.1,130.1,125.1,121.8,120.2,110.2,100.6,33.1$.

\section{5-Iodo-1 $H$-indole (110)}




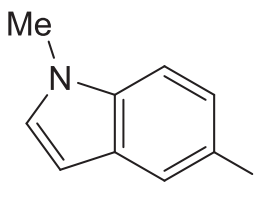

110

Starting from commercially available 5 -iodo- $1 H$-indole $(257 \mathrm{mg}, 1.00 \mathrm{mmol})$, 5-iodo-1-methyl-1H-indole 110 (380 mg, $0.755 \mathrm{mmol}, 76 \%$ yield) was obtained as a colorless solid. IR $\vee 3093$ (w), 3053 (w), 2940 (w), 2919 (w), 2886 (w), $2876(\mathrm{w}), 2856(\mathrm{w}), 1557$ (m), 1510 (s), 1473 (s), 1432 (m), 1420 (s), 1379 (w), 1329 (m), 1277 (s), 1242 (s), 1193 (w), 1151 (w), 1103 (m), 1079 (m), 1045 (w), 1007 (m), 888

(s), $868(\mathrm{~m}) .{ }^{1} \mathbf{H}$ NMR $\left(400 \mathrm{MHz}, \mathrm{CDCl}_{3}\right) \delta 7.98(\mathrm{~s}, 1 \mathrm{H}, \mathrm{ArH}), 7.49(\mathrm{~d}, J=8.6 \mathrm{~Hz}, 1 \mathrm{H}, \mathrm{ArH}), 7.13$ $(\mathrm{d}, J=8.6 \mathrm{~Hz}, 1 \mathrm{H}, \operatorname{Ar} H), 7.04(\mathrm{~s}, 1 \mathrm{H}, \operatorname{Ar} H), 6.43(\mathrm{~s}, 1 \mathrm{H}, \mathrm{ArH}), 3.80(\mathrm{~s}, 3 \mathrm{H}, \mathrm{NCH}) .{ }^{13} \mathbf{C} \mathbf{N M R}(101$ $\left.\mathrm{MHz}, \mathrm{CDCl}_{3}\right) \delta 135.8,131.0,129.8,129.7,129.6,111.3,100.3,82.9,33.0$.

\section{$\underline{\text { N-Functionalized Indoles }}$}

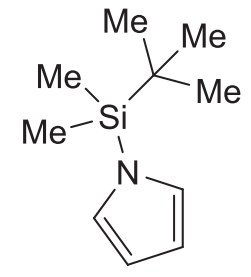

111

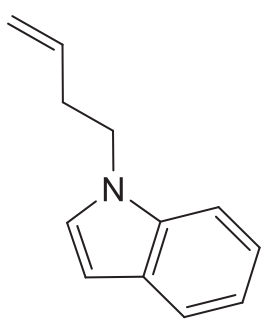

112<smiles>CC(C)(C)[Si](C)(C)n1ccc2ccccc21</smiles>

24

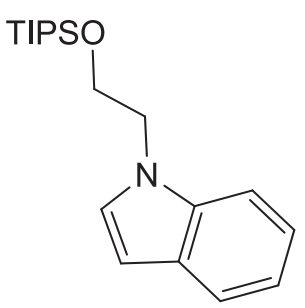

113

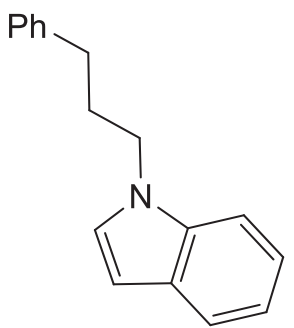

114 


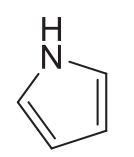

115

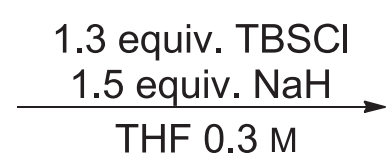

THF $0.3 \mathrm{M}$

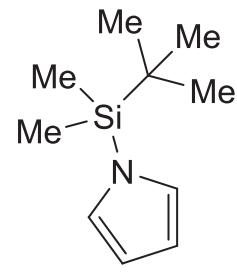

111

Following a reported procedure, ${ }^{[5]}$ commercially available $1 H$-pyrrole 115 (700 $\left.\mu 1,10.0 \mathrm{mmol}\right)$ was dissolved in dry THF (30 ml, $0.3 \mathrm{M})$. Sodium hydride $(60 \%$ suspension in mineral oil; $600 \mathrm{mg}$, $15.0 \mathrm{mmol}, 1.50$ equiv.) was slowly added under $\mathrm{N}_{2}$ flow at $0{ }^{\circ} \mathrm{C}$. After being stirred at $0^{\circ} \mathrm{C}$ for 15 min, the reaction mixture was allowed to warm to r.t for $1.50 \mathrm{~h}$. Then it was cooled back to $0^{\circ} \mathrm{C}$ and tert-butylchlorodimethylsilane (1.96 g, $13.0 \mathrm{mmol}, 1.30$ equiv.) was added. The mixture was warmed to r.t. and stirred overnight. The reaction was quenched by addition of water $(10 \mathrm{~mL})$ at $0^{\circ} \mathrm{C}$. The aqueous layer was extracted with $\mathrm{Et}_{2} \mathrm{O}(3 \mathrm{x} 10 \mathrm{~mL})$, the combined organic layers were dried over $\mathrm{MgSO}_{4}$, and the solvent was removed under reduced pressure. The crude product was purified via flash column chromatography (Pentane:EtOAc 8:1), to give the desired 1-(tertbutyldimethylsilyl)-1H-pyrrole 111 (1.30 g, 7.17 mmol, 72\% yield). IR v 3100 (w), 2956 (m), 2931 (m), 2858 (m), 1707 (w), 1473 (m), 1364 (w), 1259 (s), 1222 (w), 1190 (s), 1084 (s), 1048 (s), 1008 (w), 942 (w), 839 (s). ${ }^{1}$ H NMR (400 MHz, $\mathrm{CDCl}_{3}$ ) $\delta 6.86-6.62$ (m, 2H, ArH), $6.39-6.21$ (m, $2 \mathrm{H}, \mathrm{ArH}), 0.86\left(\mathrm{~s}, 9 \mathrm{H}, \mathrm{SiC}\left(\mathrm{CH}_{3}\right)_{3}\right), 0.41\left(\mathrm{~s}, 6 \mathrm{H}, \mathrm{Si}\left(\mathrm{CH}_{3}\right)_{2}\right) .{ }^{1} \mathrm{H}$ NMR values are in accordance with the data reported in literature. ${ }^{[11]}$

\section{1-(tert-Butyldimethylsilyl)-1H-Indole (24)}

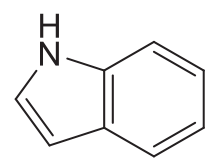

116

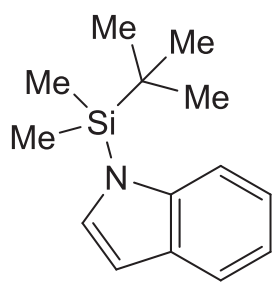

24

Following a reported procedure, ${ }^{[12]}$ commercially available $1 H$-indole 34 (586 mg, $5.00 \mathrm{mmol}$ ) was dissolved in dry THF (10 mL, $0.5 \mathrm{M})$. Sodium hydride (60\% suspension in mineral oil; $300 \mathrm{mg}$, 7.50 mmol, 1.50 equiv.) was slowly added under $\mathrm{N}_{2}$ atmosphere at $0{ }^{\circ} \mathrm{C}$. After being stirred at 0 
${ }^{\circ} \mathrm{C}$ for $15 \mathrm{~min}$, the reaction mixture was allowed to warm to r.t for $1.5 \mathrm{~h}$. Then it was cooled back to $0{ }^{\circ} \mathrm{C}$ and tert-butylchlorodimethylsilane (980 mg, $6.50 \mathrm{mmol}, 1.30$ equiv.) was added. The mixture was warmed to r.t. and stirred overnight. After cooling again to $0{ }^{\circ} \mathrm{C}$, the reaction was quenched with water $(10 \mathrm{~mL})$, extracted with $\mathrm{Et}_{2} \mathrm{O}(3 \times 10 \mathrm{~mL})$, the combined organic layers were dried over $\mathrm{MgSO}_{4}$, and the solvent was removed under reduced pressure. The residue was purified via flash column chromatography (Pentane:EtOAc 4:1), to give the desired 1-(tertbutyldimethylsilyl)- $1 H$-indole 24 (869 mg, $3.76 \mathrm{mmol}, 75 \%$ yield). ${ }^{1} \mathbf{H} \mathbf{~ N M R}$ (400 MHz, $\mathrm{CDCl}_{3}$ ) $\delta 7.79(\mathrm{~m}, 1 \mathrm{H}, \operatorname{Ar} H), 7.72(\mathrm{dt}, \mathrm{J}=8.2,1.1 \mathrm{~Hz}, 1 \mathrm{H}, \operatorname{Ar} H), 7.37(\mathrm{~d}, J=3.2 \mathrm{~Hz}, 1 \mathrm{H}, \operatorname{Ar} H), 7.32$ (ddd, $J=8.3,7.0,1.6 \mathrm{~Hz}, 1 \mathrm{H}, \operatorname{Ar} H), 7.25(\mathrm{~m}, 1 \mathrm{H}), 6.78(\mathrm{dd}, J=3.3,1.0 \mathrm{~Hz}, 1 \mathrm{H}, \operatorname{Ar} H), 1.11$ (s, 9H, $\left.\mathrm{SiCCH}_{3}\right), 0.78$ (s, 6H, Si $\left.\left(\mathrm{CH}_{3}\right)_{2}\right)$. IR $v 3064.6$ (w), 2950.5 (w), 2929.7 (m), 2855.9 (w), 1512.0 (s), 1427.6 (s), 1449.9 (m), 1284.3 (s), 1271.6 (s), 1255.8 (m), 1158.9 (s), 1140.9 (s), 984.2 (w), 840.1 (m). ${ }^{1} \mathrm{H}$ NMR values are in accordance with the data reported in literature. ${ }^{[13]}$

\section{1-(But-3-en-1-yl)-1H-Indole (112)}

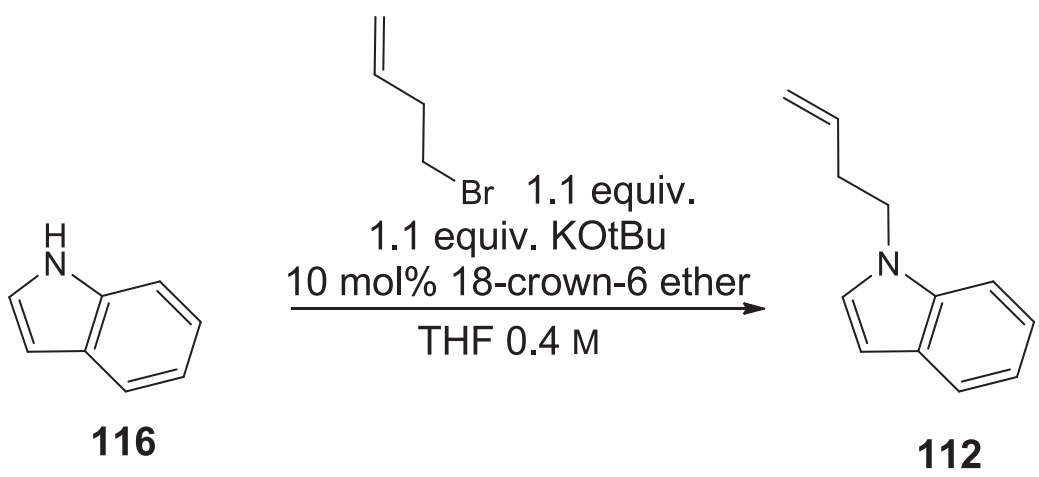

Following a reported procedure, ${ }^{[14]}$ potassium tertbutoxide $(1.24 \mathrm{mg}, 11.0 \mathrm{mmol}, 1.10$ equiv.) was added to a solution of 18-crown-6 ether $(26.4 \mathrm{mg}, 0.100 \mathrm{mmol}, 10 \mathrm{~mol} \%$.) in dry THF ( $25 \mathrm{~mL}, 0.4$ M) under a nitrogen atmosphere. Then, commercially available $1 H$-indole 116 (1.17 g, $10.0 \mathrm{mmol}$, 1.00 equiv.) was added under vigorous stirring. The reaction was cooled to $0^{\circ} \mathrm{C}$ in an ice bath. $\mathrm{A}$ solution of 4-bromobut-1-ene (1.20 mL, $11.0 \mathrm{mmol}, 1.10$ equiv.) in THF (5 mL) was added dropwise to the reaction mixture and the latter was stirred overnight. After cooling again to $0{ }^{\circ} \mathrm{C}$, the reaction was quenched with water $(20 \mathrm{~mL})$, extracted with $\mathrm{Et}_{2} \mathrm{O}(3 \times 20 \mathrm{~mL})$, the combined organic layers were dried over $\mathrm{MgSO}_{4}$, and the solvent was removed under reduced pressure. The 
residue was purified via flash column chromatography (Pentane:EtOAc 9:1) to give the desired 1(but-3-en-1-yl)-1H-indole 112 (280 mg, $1.64 \mathrm{mmol}, 17 \%$ yield) as a yellow oil. IR $v 2936$ (w), 1640 (s), 1612 (s), 1508 (m), 1458 (s), 910 (m), 740 (m), 712 (m). ${ }^{1} \mathbf{H}$ NMR (400 MHz, CDCl $\left.{ }_{3}\right) \delta$ $7.84(\mathrm{~d}, J=8.0 \mathrm{~Hz}, 1 \mathrm{H}, \operatorname{Ar} H), 7.52(\mathrm{~d}, J=8.2 \mathrm{~Hz}, 1 \mathrm{H}, \operatorname{Ar} H), 7.41(\mathrm{t}, J=7.6 \mathrm{~Hz}, 1 \mathrm{H}, \operatorname{Ar} H), 7.31$ (t, $J=7.4 \mathrm{~Hz}, 1 \mathrm{H}, \operatorname{Ar} H$ ), $7.23(\mathrm{~d}, J=3.2 \mathrm{~Hz}, 1 \mathrm{H}, \operatorname{Ar} H), 6.68(\mathrm{~d}, J=3.2 \mathrm{~Hz}, 1 \mathrm{H}, \operatorname{Ar} H), 5.94$ (ddt, $J$ $=17.1,10.2,6.8 \mathrm{~Hz}, 1 \mathrm{H}, \mathrm{ArH}), 5.32-5.12\left(\mathrm{~m}, 2 \mathrm{H}, \mathrm{NCH}_{2} \mathrm{CH}_{2} \mathrm{CH}=\mathrm{CH}_{2}\right), 4.31-4.27\left(\mathrm{~m}, 2 \mathrm{H}, \mathrm{CH}_{2}\right)$, $2.72\left(\mathrm{q}, J=7.1 \mathrm{~Hz}, 2 \mathrm{H}, \mathrm{CH}_{2}\right) .{ }^{1} \mathrm{H}$ NMR values are in accordance with the data reported in literature. ${ }^{[15]}$

\section{(2-Iodoethoxy)triisopropylsilane (118)}

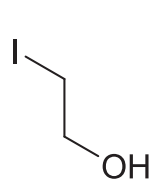

117

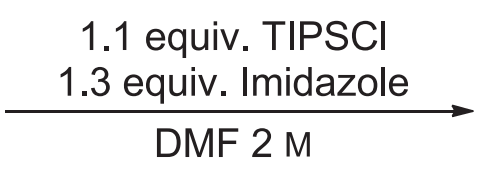

DMF 2 M

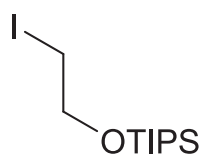

118

Following a reported procedure, ${ }^{[16]}$ commercially available 2-iodoethanol $117(1.10 \mathrm{~mL}, 10.0$ mmol, 1.00 equiv.) was added to a solution of imidazole ( $885 \mathrm{mg}, 13.0 \mathrm{mmol}, 1.30$ equiv.) in DMF $(5 \mathrm{~mL}, 2.0 \mathrm{M})$ under nitrogen atmosphere. chloro-triisopropylsilane $(2.80 \mathrm{~mL}, 13.0 \mathrm{mmol}, 1.30$ equiv.) was then added dropwise. After $1 \mathrm{~h}$, the reaction turned into a thick suspension and a colorless solid precipitated. The mixture was allowed to warm to room temperature removed and was stirred for an additional hour. Water $(5 \mathrm{~mL})$ was added to dissolve the solid. The organic layer was separated and eluted through a $\mathrm{SiO}_{2}$ plug with pentane $(100 \mathrm{~mL})$. The solvent was removed under reduced pressure to give (2-iodoethoxy)triisopropylsilane 118 (3.15 g, $9.60 \mathrm{mmol}$, 96\% yield) as a slightly yellow oil. IR $v 2958$ (m), 2942 (m), 2891 (w), 2866 (m), 1464 (m), 1384 (w), 1275 (w), 1249 (w), 1190 (w), 1169 (w), 1123 (s), 1092 (s), 1069 (s), 1013 (w), 999 (m), 943 (w), 920 (w), 882 (s), 857 (w). ${ }^{1} \mathbf{H}$ NMR (400 MHz, $\left.\mathrm{CDCl}_{3}\right) \delta 3.85$ (t, $\left.J=6.9 \mathrm{~Hz}, 2 \mathrm{H}, \mathrm{OCH}_{2}\right), 3.15$ (t, $\left.J=7.0 \mathrm{~Hz}, 2 \mathrm{H}, \mathrm{ICH}_{2}\right), 1.11-0.88(\mathrm{~m}, 21 \mathrm{H}, \mathrm{TIPS}) .{ }^{13} \mathbf{C} \mathbf{N M R}\left(101 \mathrm{MHz}, \mathrm{CDCl}_{3}\right) \delta 64.6,18.0,12.1$, 6.9 .

1-(2-((Triisopropylsilyl)oxy)ethyl)- $1 H$-Indole (113) 


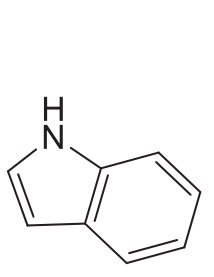

116

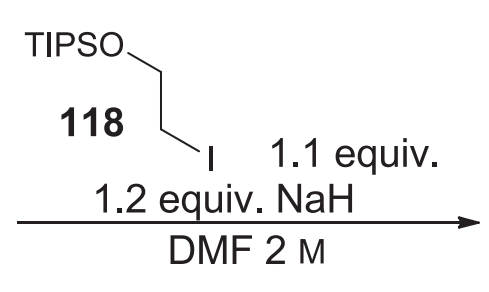

DMF $2 \mathrm{M}$

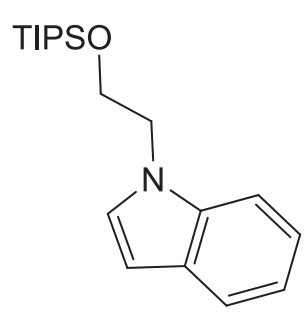

113

Commercially available $1 H$-indole 116 (586 mg, $5.00 \mathrm{mmol}$ ) was dissolved in N,Ndimethylformamide ( $5 \mathrm{~mL}, 0.5 \mathrm{M}$ in total). Sodium hydride (60\% suspension in mineral oil; 144 $\mathrm{mg}, 6.00 \mathrm{mmol}, 1.20$ equiv.) was added at r.t. and the reaction mixture was stirred for one hour. N,N-Dimethylformamide ( $5 \mathrm{~mL}$ ) was then added to dissolve the resulting colorless precipitate. The reaction was cooled to $0^{\circ} \mathrm{C}$ and (2-iodoethoxy)triisopropylsilane 118 (1.90 g, $5.50 \mathrm{mmol}, 1.10$ equiv.) was added dropwise. The reaction mixture was stirred overnight, allowing it to warm to r.t. The reaction was then quenched with water $(20 \mathrm{~mL})$ and the reaction mixture was extracted with EtOAc $(3 \times 25 \mathrm{~mL})$. The combined organic layers were washed with water $(10 \mathrm{~mL})$, brine $(3 \times 10$ $\mathrm{mL}$ ), and dried over $\mathrm{MgSO}_{4}$. The solvent was then removed under reduced pressure. Flash column chromatography (Pentane:EtOAc 9:1) afforded 1-(2-((triisopropylsilyl)oxy)ethyl)- 1H-indole 113 (1.20 g, $3.78 \mathrm{mmol}, 76 \%$ yield) as a colorless oil. IR $\vee 3056$ (w), 2891 (m), 2865 (s), 1514 (w), 1464 (s), 1439 (w), 1387 (w), 1360 (w), 1334 (w), 1317 (m), 1115 (s), 1077 (m), 1013 (m), 923 (m), 819 (w). ${ }^{1} \mathbf{H}$ NMR (400 MHz, $\left.\mathrm{CDCl}_{3}\right) \delta 7.66(\mathrm{~m}, 1 \mathrm{H}, \mathrm{Ar} H), 7.38(\mathrm{dd}, J=8.2,0.8 \mathrm{~Hz}, 1 \mathrm{H}$, $\operatorname{Ar} H), 7.25$ - $7.19(\mathrm{~m}, 2 \mathrm{H}, \operatorname{Ar} H), 7.13(\mathrm{~m}, 1 \mathrm{H}, \operatorname{Ar} H), 6.52(\mathrm{dd}, J=3.1,0.8 \mathrm{~Hz}, 1 \mathrm{H}, \operatorname{Ar} H), 4.30(\mathrm{t}, J$ $\left.=6.0 \mathrm{~Hz}, 2 \mathrm{H}, \mathrm{CH}_{2}\right), 4.04\left(\mathrm{t}, J=5.8 \mathrm{~Hz}, 2 \mathrm{H}, \mathrm{CH}_{2}\right), 1.17-0.85\left(\mathrm{~m}, 21 \mathrm{H}\right.$, TIPS). ${ }^{13} \mathbf{C}$ NMR $(101$ $\left.\mathrm{MHz}, \mathrm{CDCl}_{3}\right) \delta 136.1,128.7,128.6,121.3,120.9,119.2,109.3,101.0,62.8,48.8,17.9,11.9$.

\section{1-(3-Phenylpropyl)-1 $H$-indole (114)}

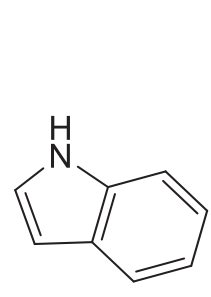

116

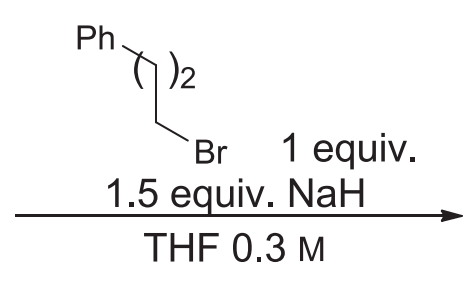

THF $0.3 \mathrm{M}$

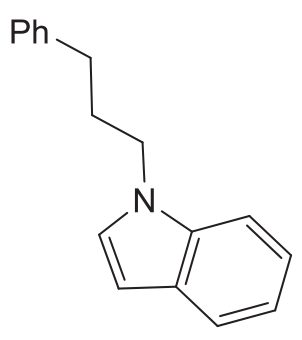

114 
Following a reported procedure, ${ }^{[17]}$ commercially available $1 H$-indole 116 (585 mg, $5.00 \mathrm{mmol}$, 1.00 equiv.) was dissolved in THF $(15 \mathrm{~mL})$. Sodium hydride (60\% suspension in mineral oil; 300 $\mathrm{mg}, 7.50 \mathrm{mmol}, 1.50$ equiv.) was added at $0{ }^{\circ} \mathrm{C}$ and the reaction mixture was stirred for $30 \mathrm{~min}$. (3bromopropyl)benzene ( $760 \mu \mathrm{L}, 5.00 \mathrm{mmol}, 1.00$ equiv.) was then added dropwise. After $15 \mathrm{~min}$ the ice bath was removed and the reaction mixture was stirred for 4 hours at r.t.. The reaction was cooled back to $0{ }^{\circ} \mathrm{C}$, quenched with water, diluted with EtOAc $(10 \mathrm{~mL})$, extracted with water $(2 \mathrm{x}$ $10 \mathrm{~mL})$, washed with brine $(10 \mathrm{~mL})$, and dried over $\mathrm{MgSO}_{4}$. After filtration, the solvent was removed under reduced pressure. Flash column chromatography (Pentane:EtOAc 20:1) afforded 1-(3-phenylpropyl)-1H-indole 114 (1.12 g, 4.76 mmol, 95\% yield) as a colorless oil. IR 3085 (w), 3057 (w), 3026 (w), 3004 (w), 2946 (w), 2945 (w), 2870 (w), 1780 (w), 1738 (s), 1717 (s), 1612 (w), 1603 (w), 1511 (m), 1497 (m), 1483 (m), 1464 (s), 1455 (s), 1400 (m), 1377 (s), 1354 (s), 1336 (s), 1315 (s), 1254 (s), 1207 (s), 1179 (m), 1166 (m), 1143 (m), 1143 (m), 1122 (m), 1114 (m), $1080(\mathrm{~m}), 1031$ (m), $1020(\mathrm{~m}), 1004$ (w), 952 (w), 928 (w), 909 (w), $885(\mathrm{~m}), 855$ (w), 838 (w), 821 (w), 811 (w), 802 (w). ${ }^{1} \mathbf{H}$ NMR $\left(400 \mathrm{MHz}, \mathrm{CDCl}_{3}\right) \delta 7.87$ (d, $\left.J=8 \mathrm{~Hz}, 1 \mathrm{H}, \mathrm{ArH}\right), 7.53$ $7.23(\mathrm{~m}, 9 \mathrm{H}, \mathrm{ArH}), 6.72(\mathrm{dd}, J=3.1,0.8 \mathrm{~Hz}, 1 \mathrm{H}, \mathrm{Ar} H), 4.26\left(\mathrm{t}, J=7.1 \mathrm{~Hz}, 2 \mathrm{H}, \mathrm{NCH}_{2}\right), 2.77(\mathrm{t}, J$ $=8 \mathrm{~Hz}, 2 \mathrm{H}, \mathrm{CH}_{2} \mathrm{Ph}$ ), 2.34 (qi, $\left.J=7.8 \mathrm{~Hz}, 2 \mathrm{H}, \mathrm{CH}_{2} \mathrm{CH}_{2} \mathrm{CH}_{2}\right) .{ }^{13} \mathbf{C ~ N M R}\left(101 \mathrm{MHz}, \mathrm{CDCl}_{3}\right) \delta 141.2$, 136.2, 128.7, 128.7, 128.6, 128.0, 126.3, 121.6, 121.2, 119.5, 109.6, 101.3, 45.8, 33.2, 31.7 (one aromatic Carbon signal not resolved).

\subsection{Synthesis of compound 10/11.}
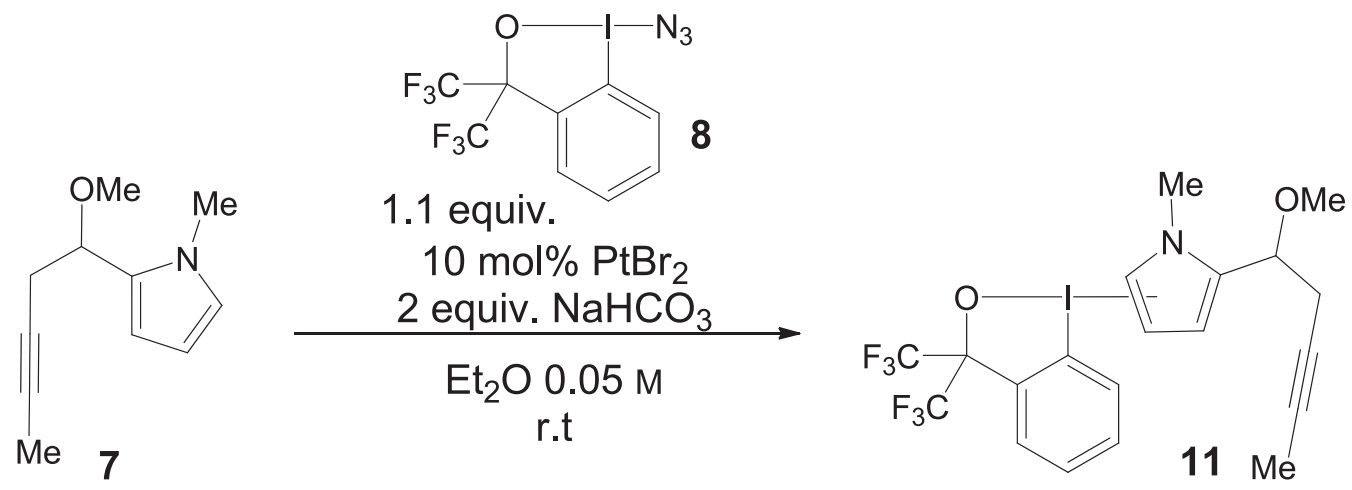

A solution of 2-(1-methoxypent-3-yn-1-yl)-1-methyl- $1 H$-pyrrole 7 ( $0.100 \mathrm{mmol}, 1.0$ equiv) in THF $(0.33 \mathrm{~mL})$ was added into a solution of $\mathrm{PtBr}_{2}\left(3.55 \mathrm{mg}, 10.0 \mu \mathrm{mol}, 0.10\right.$ equiv), $\mathrm{NaHCO}_{3}(17.0 \mathrm{mg}$, $0.200 \mathrm{mmol}, 2.0$ equiv) and 1-azido-3,3-bis(trifluoromethyl)-3-(1H)-1,2-benziodoxole 8 (330 mg, $0.600 \mathrm{mmol}, 2.00$ equiv) in $\mathrm{CH}_{3} \mathrm{CN}(0.180 \mathrm{~mL})$. The reaction was stopped after $72 \mathrm{hrs}$, EtOAc was 
added to solubilize the precipitate and a TLC (Pentane:EtOAc 4:1 for the starting, DCM:MeOH 9:1 for the product) was taken: full conversion of the starting to 11 . The solvent was removed under reduced pressure, and a crude NMR (extremely wet of EtOAc) and a MS analysis were taken.

HR-ESI-MS $546.0372\left([\mathrm{M}+\mathrm{H}]^{+}, \mathrm{C}_{20} \mathrm{H}_{18} \mathrm{~F}_{6} \mathrm{INO}_{2}{ }^{+}\right.$; calc. for 545.02864)

The crude ${ }^{1} \mathrm{H}-\mathrm{NMR}$ shows a 2:1 ratio between known peaks of iodobenzoic hexafluorodimethylalcohol and the new product. The peak of the new compound are reported here:

${ }^{1} \mathbf{H}$ NMR $\left(400 \mathrm{MHz}, \mathrm{CDCl}_{3}\right) \delta 7.83(\mathrm{dd}, J=6.8,1.4 \mathrm{~Hz}, 1 \mathrm{H}, \mathrm{Ar} H), 7.75-7.70(\mathrm{~m}, 1 \mathrm{H}, \mathrm{ArH}), 7.69$ - $7.64(\mathrm{~m}, 1 \mathrm{H}, \operatorname{Ar} H), 6.59$ (d, $J=2.2 \mathrm{~Hz}, 1 \mathrm{H}, \operatorname{Ar} H), 6.14$ (dd, $J=3.6,1.8 \mathrm{~Hz}, 1 \mathrm{H}, \operatorname{Ar} H), 6.06$ (dd, $J=3.6,2.7 \mathrm{~Hz}, 1 \mathrm{H}, \mathrm{ArH}), 4.49(\mathrm{dd}, J=7.5,6.3 \mathrm{~Hz}, 1 \mathrm{H}, \mathrm{CH}), 3.65\left(\mathrm{~m}, 3 \mathrm{H}, \mathrm{CH}_{3}\right), 3.24(\mathrm{~m}, 3 \mathrm{H}$, $\left.\mathrm{CH}_{3}\right), 2.77\left(\mathrm{~m}, 1 \mathrm{H}, \mathrm{CH}_{2}\right), 2.64\left(\mathrm{~m}, 1 \mathrm{H}, \mathrm{CH}_{2}\right), 1.77\left(\mathrm{t}, \mathrm{J}=2.5 \mathrm{~Hz}, 3 \mathrm{H}, \mathrm{CH}_{3}\right)$.

Subsequently, the crude was columned over silica using an eluent mixture of 9:1 DCM:MeOH; no product was obtained as the compound degraded on silica.

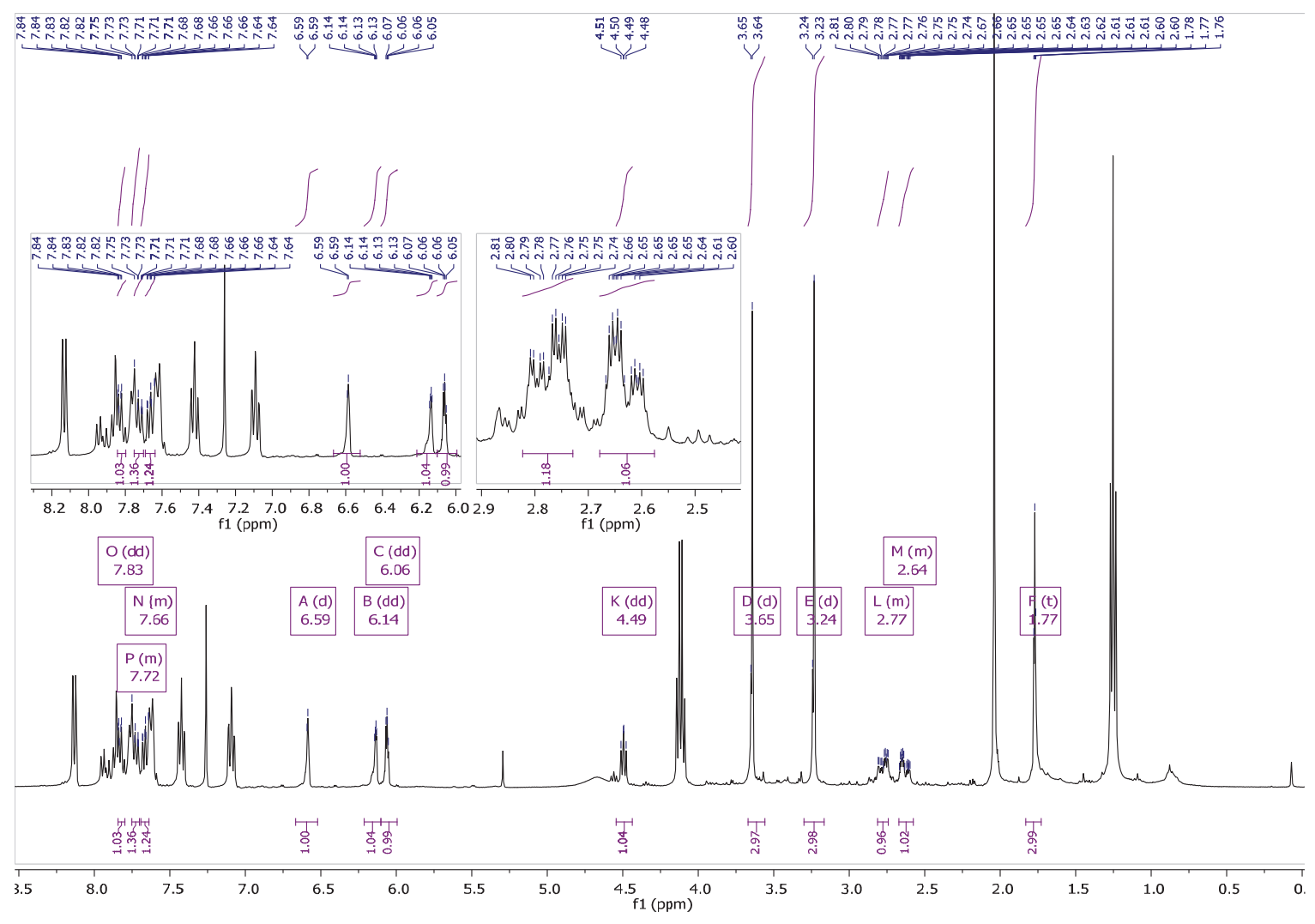




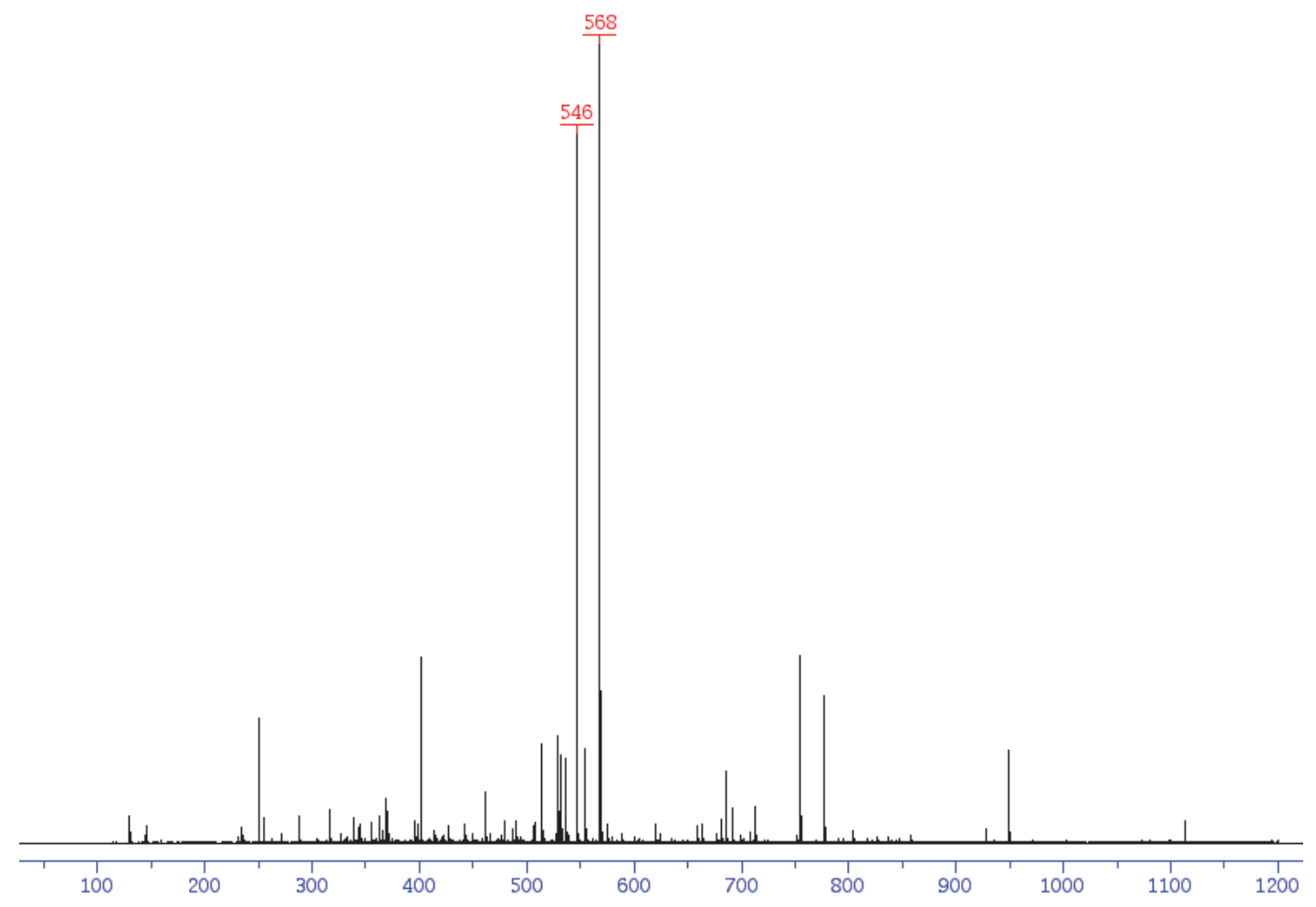

\subsection{Optimization in the synthesis of IndoleBX 21.}

Table S1: Screening of additives

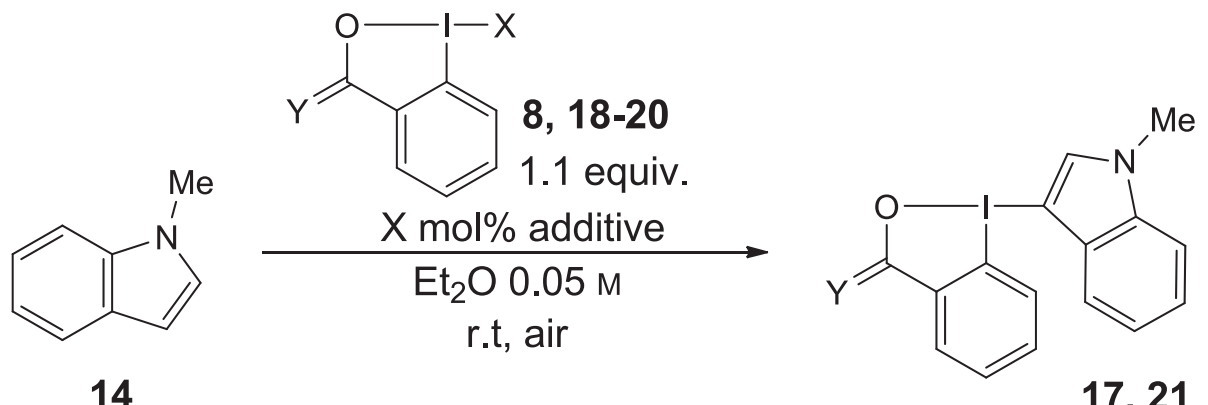

\begin{tabular}{ccccc}
\hline Entry & $\mathbf{Y}$ & $\mathbf{X}$ & Additive (mol\%) & Yield\% $^{\mathbf{a}}$ \\
\hline 1 & $\left(\mathrm{CF}_{3}\right)_{2}$ & $\mathrm{~N}_{3}(\mathbf{8})$ & - & $25 \%$ \\
2 & $\left(\mathrm{CF}_{3}\right)_{2}$ & $\mathrm{OAc} \mathrm{(18)}$ & - & - \\
3 & $\left(\mathrm{CF}_{3}\right)_{2}$ & $\mathrm{OAc} \mathrm{(18)}$ & $\mathrm{Zn}(\mathrm{OTf})_{2}(10)$ & $56 \%$ \\
4 & $\mathrm{O}$ & $\mathrm{OH} \mathrm{(19)}$ & $\mathrm{TMSOTf}(10)$ & $-\mathrm{b}$ \\
5 & $\mathrm{O}$ & $\mathrm{OH} \mathrm{(19)}$ & $\mathrm{Zn}(\mathrm{OTf})_{2}(10)$ & $-\mathrm{b}$
\end{tabular}




\begin{tabular}{|c|c|c|c|c|}
\hline 6 & $\mathrm{O}$ & OAc (20) & - & $-\mathrm{b}$ \\
\hline 7 & $\mathrm{O}$ & OAc (20) & TMSOTf (10) & $16 \%$ \\
\hline 8 & $\mathrm{O}$ & OAc (20) & $\mathbf{Z n}(\mathbf{O T f})_{2}$ & $36 \%$ \\
\hline 9 & $\mathrm{O}$ & OAc (20) & $\mathrm{Cu}(\mathrm{OTf})_{2}(10)$ & $36 \%{ }^{\mathrm{c}}$ \\
\hline 10 & $\mathrm{O}$ & OAc (20) & $\operatorname{AgNTf}_{2}(20)$ & $-\mathrm{c}$ \\
\hline 11 & $\mathrm{O}$ & OAc (20) & $\operatorname{AgF}(20)$ & $-^{c}$ \\
\hline 12 & $\mathrm{O}$ & OAc (20) & CsF (20) & $-\mathrm{c}$ \\
\hline 13 & $\mathrm{O}$ & OAc (20) & TBAF (20) & $-c$ \\
\hline
\end{tabular}

a) Substrate $14(0.100 \mathrm{mmol})$, reagents $8, \mathbf{1 8 - 2 0}(0.110 \mathrm{mmol})$, additive $(\mathrm{X} \mathrm{mol} \%)$, and $\mathrm{Et}_{2} \mathrm{O}(0.05$

$\mathrm{M})$ at $25{ }^{\circ} \mathrm{C}$. Isolated yield after flash chromatography is given. b) No conversion: starting materials recovered. c) Complete decomposition of the hypervalent iodine reagents.

Table S2: Screening of solvents and additive loading

\begin{tabular}{cccc}
\hline Entry & Solvent & X mol\% Zn(OTf) & Yield\% $^{\mathbf{a}}$ \\
\hline 1 & THF & 10 & $-\mathrm{b}$ \\
2 & THF & 20 & $-\mathrm{b}$ \\
3 & THF & 1 equiv. & $-\mathrm{b}$ \\
4 & DCM & 10 & Full conversion $^{\mathrm{c}}$ \\
5 & DCM & $\mathbf{2 0}$ & $\mathbf{9 7 \%}$ \\
6 & DCM & 1 equiv. & decomposition \\
\hline
\end{tabular}

a) Substrate 14 (0.100 mmol), AcOBX 20 (0.110 mmol), Zn(OTf) 2 (x mol\%), and solvent $(0.05 \mathrm{M})$ at $25{ }^{\circ} \mathrm{C}$. Isolated yield after flash chromatography is given. b) No conversion: starting materials recovered. c) 2 equiv. of OAcBX 20 are needed.

\section{$\underline{\text { 2.5 Preparation of PyrroleBX and IndoleBX Reagents. }}$}

General Procedure GP2 for the Synthesis of Heterocyclic-BX Reagents 17, 21, 23, 25-47, 49 


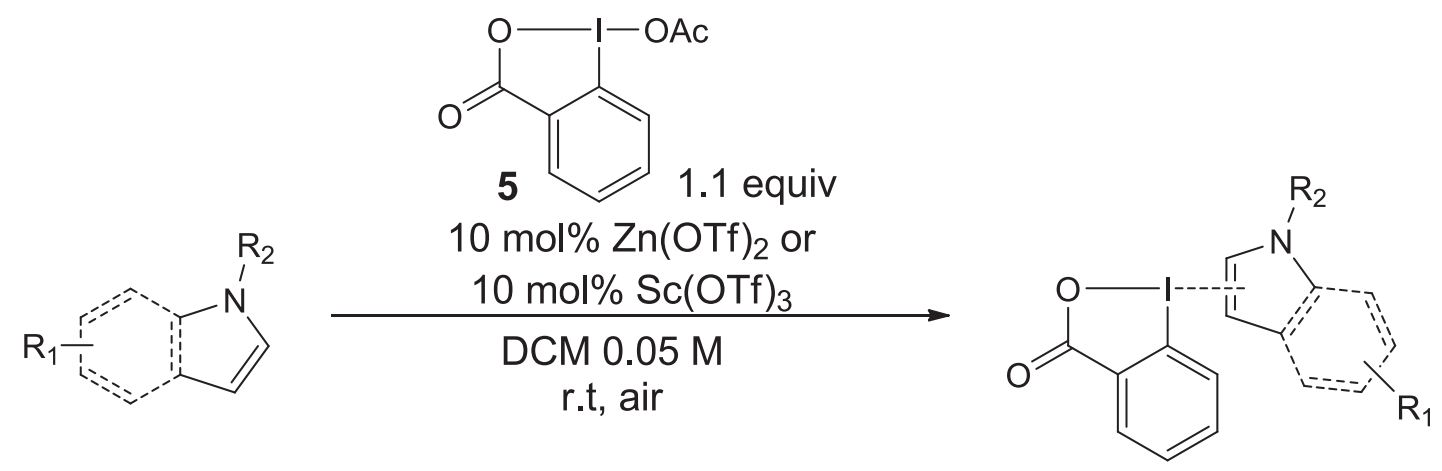

Note: prior to the reaction, the glassware requires to be carefully cleaned with aqua regia to remove all metal traces; the commercially available heterocyclic starting material were purified through a short plug of silica prior to being used.

Procedure A for $1.00 \mathrm{mmol}$ : in an open air flask, the corresponding heterocycle (1.00 mmol, 1.00 equiv.), freshly prepared Acetoxy-benziodoxole 20 (1.10 mmol, 1.10 equiv.) and Zinc(II) trifluoromethanesulfonate $(72.7 \mathrm{mg}, 0.200 \mathrm{mmol}, 20 \mathrm{~mol} \%$.) were dissolved in DCM (20 mL 0.05 M). The reaction was stirred while being monitored by TLC (Pentane:EtOAc 9:1 for the starting materials, DCM:MeOH 9:1 for the products). Upon consumption of the starting material, the crude was directly submitted to short-path flash chromatography (DCM:MeOH 10:1 or EtOAc:MeOH 10:1 for the separation of pyrrole-based reagents) to afford the desired Heterocyclic-BX compounds 17, 21, 23, 25-37, 43-48.

Procedure B for $0.200 \mathrm{mmol}$ : in an open air flask, the corresponding heterocycle $(0.200 \mathrm{mmol}$, 1.00 equiv.), freshly prepared Acetoxy-benziodoxoles 17, 23, 95-97 (0.220 mmol, 1.10 equiv.) and zinc(II) trifluoromethanesulfonate $(7.27 \mathrm{mg}, 0.040 \mathrm{mmol}, 20 \mathrm{~mol} \%$.) were dissolved in DCM (4 $\mathrm{mL} 0.05 \mathrm{M}$ ). The reaction was stirred while being monitored by TLC (Pentane:EtOAc 9:1 for the starting materials, DCM:MeOH 9:1 for the products). Upon consumption of the starting material, the crude was directly submitted to short-path flash chromatography (DCM:MeOH 10:1 or EtOAc:MeOH 10:1 for the separation of pyrrole-based reagents) to afford the desired HeterocyclicBX compounds 32-43.

The structure of compounds 25 and 34 was confirmed by X-Ray analysis (see par. 5 of the Supplementary Informations). 
<smiles>Cn1cc(I2OC(C(F)(F)F)(C(F)(F)F)c3ccccc32)c2ccccc21</smiles>

17

$56 \%$ yield<smiles>Cn1cc(I2OC(C)(C)c3ccccc32)c2ccccc21</smiles>

23

$51 \%$ yield<smiles>Cn1cc(I2COC(=O)c3ccccc32)c2ccccc21</smiles>

21

$87 \%$ yield<smiles>O=C1OI(c2c[nH]c3ccccc23)c2ccccc21</smiles>

25

$78 \%$ yield

Figure S1: Scope of Heterocyclic-BX reagents (1)

\section{1-(3-1-Methyl-1H-indole)-3,3-bis(trifluoromethyl)-1,3-dihydro-1 $\lambda_{3}$-benzo $[d][1,2]$ iodaoxole} (17)<smiles>Cn1cc(I2OC(C(F)(F)F)(C(F)(F)F)c3ccccc32)c2ccccc21</smiles>

17 Following procedure B: starting from commercially available 1methyl-1-H-indole 14 (26.2 mg, $0.100 \mathrm{mmol})$, 1-acetoxy-1,3dihydro-3,3-bis(trifluoromethyl)-1,2-benziodoxole 18 (94.0 mg, 0.220 mmol, 1.10 equiv.) and in $\mathrm{Et}_{2} \mathrm{O} 0.05 \mathrm{M}$, after 16 hours 1-(3-1methyl- $1 H$-indole)-3,3-bis(trifluoromethyl)-1,3-dihydro- $1 \lambda^{3}$ benzo[d][1,2]iodaoxole $17(56.1 \mathrm{mg}, 0.112 \mathrm{mmol}, 56 \%$ yield $)$ was obtained as a brown foam. Rf: 0.7 (DCM:MeOH 9:1). IR $v 3069$ (w), 2922 (w), 2852 (w), 1732 (w), 1504 (m), 1457 (w), 1263 (s), 1212 (m), 1178 (s), 1157 (s), 1130 (m), 1047 (w), 948 (s). ${ }^{1} \mathbf{H}$ NMR $\left(400 \mathrm{MHz}, \mathrm{CDCl}_{3}\right) \delta 7.86(\mathrm{~m}, 1 \mathrm{H}, \mathrm{ArH}), 7.53$ (s, 1H, NCHCI), $7.52-7.46(\mathrm{~m}, 3 \mathrm{H}, \operatorname{Ar} H)$, 7.41 (ddd, $J=8.3,7.0,1.1 \mathrm{~Hz}, 1 \mathrm{H}, \operatorname{Ar} H), 7.28$ (m, 1H, ArH), 7.23 (m, 1H, ArH), 6.95 (d, $J=8.3$ $\mathrm{Hz}, 1 \mathrm{H}, \mathrm{ArH}), 3.96$ (s, 3H, $\left.\mathrm{NCH}_{3}\right) .{ }^{13} \mathbf{C}$ NMR $\left(101 \mathrm{MHz}, \mathrm{CDCl}_{3}\right) \delta$ 137.5, 137.4, 131.7, 131.4, $130.1,129.9,126.9,123.9,123.2$ (m), 122.1, 120.4, 112.2, 110.3, 84.2, 81.55 (dt, $J=57.1,28.5$ Hz), 33.6 (one aromatic Carbon signal not resolved). HR-ESI-MS $499.9946\left([\mathrm{M}+\mathrm{H}]^{+}\right.$, 
$\mathrm{C}_{18} \mathrm{H}_{13} \mathrm{~F}_{6} \mathrm{INO}^{+}$; calc. for 499.9941). The structure of the obtained regioisomer was assigned by NMR analysis. ${ }^{[18]}$

\section{1-(3-1-Methyl-1H-indole)-1 $H$-1 $\lambda_{3}$-benzo[b]iodo-3(2H)-one (21)}<smiles>Cn1cc(I2COC(=O)c3ccccc32)c2ccccc21</smiles>

21

The synthesis of 1-(3-1-methyl- $1 H$-indole)- $1 H-1 \lambda_{3}$-benzo[b]iodo$3(2 \mathrm{H})$-one 21 was scaled up to $10 \mathrm{mmol}$ without reoptimization of the protocol.

Following procedure $\mathbf{A}$ : starting from commercially available 1-methyl1-H-indole 14 (1.35 g, $10.0 \mathrm{mmol})$, after 16 hours 1-(3-1-methyl-1Hindole)-1H-1 $\lambda_{3}$-benzo[b]iodo-3(2H)-one 21 (3.28 g, $8.70 \mathrm{mmol}, 87 \%$ yield) was obtained as a brown foam. Rf: 0.4 (DCM:MeOH 9:1). IR v 3107 (w), 3059 (w), 2948 (w), 1599 (s), 1552 (m), 1506 (m), 1454 (w), 1392 (m), 1277 (s), 1245 (s), 1225 (s), 1166 (s), 1131 (m), 1031 (s), 1004 (w), $842(\mathrm{w}) .{ }^{1} \mathbf{H}$ NMR $\left(400 \mathrm{MHz}, \mathrm{CDCl}_{3}\right) \delta 8.40(\mathrm{dd}, J=7.5,1.7 \mathrm{~Hz}, 1 \mathrm{H}, \mathrm{ArH}), 7.82(\mathrm{~s}, 1 \mathrm{H}, \mathrm{NCHCI})$, $7.55-7.48(\mathrm{~m}, 2 \mathrm{H}, \mathrm{ArH}), 7.39-7.35(\mathrm{~m}, 2 \mathrm{H}, \mathrm{ArH}), 7.34-7.23\left(\mathrm{~m}, 2 \mathrm{H}, \mathrm{Ar} H+\mathrm{CDCl}_{3}\right), 6.84(\mathrm{~d}$, $J=8.3 \mathrm{~Hz}, 1 \mathrm{H}, \mathrm{ArH}), 4.02\left(\mathrm{~s}, 3 \mathrm{H}, \mathrm{NCH}_{3}\right) .{ }^{13} \mathrm{C}$ NMR $(101 \mathrm{MHz}, \mathrm{CDCl} 3) \delta 166.8,138.6,137.6$, $133.4,133.3,132.5,130.5,129.3,125.2,124.3,122.6,119.9,116.1,110.7,78.9,33.9$. HR-ESIMS $377.9990\left([\mathrm{M}+\mathrm{H}]^{+}, \mathrm{C}_{16} \mathrm{H}_{13} \mathrm{INO}_{2}{ }^{+}\right.$; calc. for 377.9986). The structure of the obtained regioisomer was assigned by NMR correlation to compound 25. DSC-analysis was performed on compound 21: see par.5 of Supplementary informations.

\section{1-(3-1-Methyl-1 $H$-indole)-3,3-dimethyl-1,3-dihydro-1 $\lambda^{3}$-benzo[ $\left.d\right][1,2]$ iodoxole (23)}

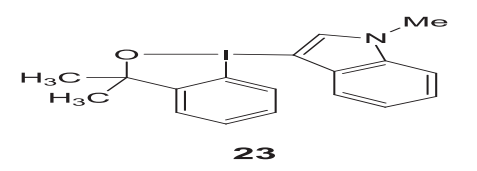

Following procedure B: starting from commercially available 1methyl-1-H-indole 14 (26.2 mg, $0.100 \mathrm{mmol})$ and 3,3-dimethyl- $1 \lambda_{3}$ benzo[ $d][1,2]$ iodoxol-1 $(3 H)$-yl acetate $22(70.4 \mathrm{mg}, 0.220 \mathrm{mmol}$, 1.10 equiv.), after 16 hours 1-(3-1-methyl-1H-indole)-3,3-dimethyl1,3-dihydro-1 $\lambda^{3}$-benzo[ $\left.d\right][1,2]$ iodoxole $23(40.1 \mathrm{mg}, 0.102 \mathrm{mmol}$, 51\% yield) was obtained as a brown foam. Rf: 0.7 (DCM:MeOH 9:1).

IR $v 3115(\mathrm{w}), 3050(\mathrm{w}), 2986(\mathrm{w}), 1509(\mathrm{w}), 1455(\mathrm{w}), 1372(\mathrm{w}), 1284$ (s), 1247 (s), 1225 (m), 1166 (m), 1110 (w), 1031 (s), 992 (w). ${ }^{1} \mathbf{H}$ NMR (400 MHz, CDCl $)_{3} \delta 7.92$ (s, 1H, NCHCI), 7.54 (m, 1H, ArH), 7.47 (m, 1H, ArH), $7.45-7.40$ (m, 3H, ArH), 7.34 (ddd, J=8.0, 6.9, 1.0 Hz, 1H, 
ArH), 7.08 (ddd, $J=8.7,5.8,2.9 \mathrm{~Hz}, 1 \mathrm{H}, \mathrm{ArH}), 6.87$ (m, 1H, $\mathrm{ArH}), 4.02$ (s, 3H, NCH3), 1.75 (s, $\left.6 \mathrm{H}, \mathrm{C}\left(\mathrm{CH}_{3}\right)_{2}\right) .{ }^{13} \mathbf{C} \mathbf{N M R}\left(101 \mathrm{MHz}, \mathrm{CDCl}_{3}\right) \delta 146.3,140.2,137.7,130.9,130.4,128.9,128.7$, 127.0, 124.8, 123.3, 119.6, 111.0, 108.9, 74.6, 72.9, 34.2, 30.5. HR-ESI-MS $392.0510\left([\mathrm{M}+\mathrm{H}]^{+}\right.$, $\mathrm{C}_{18} \mathrm{H}_{19} \mathrm{INO}^{+}$; calc. for 392.0506). The structure of the obtained regioisomer was assigned by NMR correlation to compound 17.

\section{1-(3-1H-indole)-1H-1 $\lambda_{3}$-benzo[b]iodo-3(2H)-one (25)}<smiles>O=C1OI(c2c[nH]c3ccccc23)c2ccccc21</smiles>

25

Following procedure A: starting from 1-(tert-butyldimethylsilyl)- $1 \mathrm{H}$ indole $24(231 \mathrm{mg}, 1.00 \mathrm{mmol})$ and using $\mathrm{Sc}(\mathrm{OTf})_{3}$ as the Lewis acid (20 mol \%), after 16 hours $1-\left(3-1 H\right.$-indole)- $1 H-1 \lambda_{3}$-benzo $[b]$ iodo-3( $\left.2 H\right)$-one 25 (294 mg, $8.10 \mathrm{mmol}, 78 \%$ yield) was obtained as a brown solid. Rf: 0.4 (DCM:MeOH 9:1). Mp: $174.2^{\circ} \mathrm{C}$ (decomposition). IR $v 3302$ (w), 2975 (w), 2903 (w), 1722 (w), 1609 (m), 1584 (m), 1557 (w), 1490 (w), 1457 (w), 1385 (w), 1277 (s), 1258 (s), 1230 (m), 1174 (m), 1087 (w), 1036 (s), 880 (w), 841 (w). ${ }^{1}$ H NMR (400 MHz, DMSO-d $\left.d_{6}\right) 12.33(\mathrm{~s}, 1 \mathrm{H}, \mathrm{N} H), 8.21(\mathrm{~s}, 1 \mathrm{H}, \mathrm{NCHCI}), 8.08$ (dd, $\left.J=7.3,1.7 \mathrm{~Hz}, 1 \mathrm{H}, \mathrm{Ar} H\right), 7.59$ (d, $J=8.2 \mathrm{~Hz}, 1 \mathrm{H}, \operatorname{Ar} H), 7.52(\mathrm{t}, J=7.3 \mathrm{~Hz}, 1 \mathrm{H}, \operatorname{Ar} H), 7.43(\mathrm{~d}, J=7.5 \mathrm{~Hz}, 1 \mathrm{H}, \operatorname{Ar} H), 7.36$ (ddd, $J=$ 8.5, 7.3, $1.7 \mathrm{~Hz}, 1 \mathrm{H}, \mathrm{Ar} H), 7.26(\mathrm{ddd}, J=8.2,7.0,1.2 \mathrm{~Hz}, 1 \mathrm{H}, \mathrm{Ar} H), 7.15(\mathrm{t}, J=7.5 \mathrm{~Hz}, 1 \mathrm{H}, \mathrm{Ar} H)$, $6.72(\mathrm{~d}, J=8.5 \mathrm{~Hz}, 1 \mathrm{H}, \mathrm{Ar} H) .{ }^{13} \mathbf{C}$ NMR (101 MHz, DMSO- $\left.d_{6}\right) \delta 166.1,136.6,134.5,133.3,131.4$, 130.2, 128.5, 126.3, 123.4, 122.3, 121.6, 119.2, 116.1, 112.9, 80.0. HR-ESI-MS 363.9832 $\left([\mathrm{M}+\mathrm{H}]^{+}, \mathrm{C}_{15} \mathrm{H}_{11} \mathrm{INO}_{2}{ }^{+}\right.$; calc. for 363.9829). The structure of the reagent was determined through $X$-Ray diffraction of a single crystal (CCDC number: 1540821). 
<smiles>Cc1c(I2COC(=O)c3ccccc32)c2ccccc2n1C</smiles>

26

$91 \%$ yield<smiles>Cn1cc(I2COC(=O)c3ccccc32)c2cc(Cl)ccc21</smiles>

29

$62 \%$ yield<smiles>COc1ccc2c(c1)c(I1COC(=O)c3ccccc31)cn2C</smiles>

27

$87 \%$ yield<smiles>Cn1cc(I)c2cc(I)ccc21</smiles>

30

$76 \%$ yield<smiles>Cn1cc(I2COC(=O)c3ccccc32)c2cc(F)ccc21</smiles>

28

$85 \%$ yield<smiles>Cn1cc(I)c2cc(Br)ccc21</smiles>

31

$54 \%$ yield

Figure S2: Scope of Heterocyclic-BX reagents (2)

\section{1-(3-1,2-Dimethyl-1 $H$-indole)-1H-1 $\lambda_{3}$-benzo[b]iodo-3(2H)-one (26)}<smiles>Cc1c(I2COC(=O)c3ccccc32)c2ccccc2n1C</smiles>

26

Following procedure A: starting from 2-methyl-1-methyl-1 $H$-indole 106 (145 mg, $1.00 \mathrm{mmol})$, after 16 hours 1-(3-1,2-dimethyl- $1 H$-indole)- $1 H$ $1 \lambda_{3}$-benzo[b]iodo-3(2H)-one 26 (364 $\mathrm{mg}, 0.930 \mathrm{mmol}, 93 \%$ yield) was obtained as a dark violet foam. Rf: 0.43 (DCM:MeOH 9:1). IR v 3055 (w), 2987 (w), 2948 (w), 1717 (w), 1605 (s), 1584 (m), 1553 (m), 1516 (w), $1472(\mathrm{w}), 1437(\mathrm{w}), 1395(\mathrm{~m}), 1378(\mathrm{~m}), 1268(\mathrm{~m}), 1154(\mathrm{w}), 1032$ (w), $1011(\mathrm{w}), 829(\mathrm{w}) .{ }^{1} \mathbf{H}$ NMR (400 MHz, $\left.\mathrm{CDCl}_{3}\right) \delta 8.42(\mathrm{dd}, J=7.3,1.7 \mathrm{~Hz}, 1 \mathrm{H}, \mathrm{ArH}), 7.52$ (td, $J=7.3,0.9 \mathrm{~Hz}, 1 \mathrm{H}, \operatorname{Ar} H), 7.44(\mathrm{~d}, J=8.2 \mathrm{~Hz}, 1 \mathrm{H}, \operatorname{Ar} H), 7.35(\mathrm{~m}, 2 \mathrm{H}, \operatorname{Ar} H), 7.28(\mathrm{~m}, 1 \mathrm{H}$, ArH), 7.23 (ddd, $J=8.2,6.9,1.0 \mathrm{~Hz}, 1 \mathrm{H}, \mathrm{ArH}), 6.77$ (m, 1H, $\mathrm{ArH}), 3.91\left(\mathrm{~s}, 3 \mathrm{H}, \mathrm{CH}_{3} \mathrm{~N}\right), 2.65$ (s, $\left.3 \mathrm{H}, \mathrm{ICH}=\mathrm{CHCH}_{3}\right) .{ }^{13} \mathbf{C}$ NMR $\left(101 \mathrm{MHz}, \mathrm{CDCl}_{3}\right) \delta 166.8,145.3,137.9,133.7,133.2,132.7,130.5$, 128.9, 124.7, 123.6, 122.4, 119.2, 115.5, 110.4, 80.1, 31.1, 13.2. HR-ESI-MS 392.0146 ([M+H]+, $\mathrm{C}_{17} \mathrm{H}_{15} \mathrm{INO}_{2}^{+}$; calc. for 392.0142). The structure of the obtained regioisomer was assigned by NMR correlation to compound 25. 


\section{1-(3-5-Methoxy-1-methyl-1H-indole)-1H-1 $\lambda_{3}$-benzo $[b]$ iodo-3(2H)-one (27)}<smiles>COc1ccc2c(c1)c(I1COC(=O)c3ccccc31)cn2C</smiles>

Following procedure A: starting from 5-methoxy-1-methyl- $1 H$-indole 107 (161 mg, $1.00 \mathrm{mmol})$, after 16 hours 1-(3-5-methoxy-1-methyl-1Hindole)- $1 H-1 \lambda_{3}$-benzo[b]iodo-3(2H)-one 27 (346 mg, $0.850 \mathrm{mmol}, 85 \%$ yield) was obtained as an orange resin. Rf: 0.42 (DCM:MeOH 9:1). IR v $3110(\mathrm{w}), 3062(\mathrm{w}), 3000(\mathrm{w}), 2944$ (w), 2837 (w), 1719 (w), 1604 (m), $1584(\mathrm{~m}), 1556(\mathrm{w}), 1504$ (m), 1489 (m), 1439 (w), 1378 (w), 1249

(s), 1223 (s), 1158 (m), 1031 (s), 970 (w), 845 (m). ${ }^{\mathbf{1}} \mathbf{H}$ NMR (400 MHz, $\left.\mathrm{CDCl}_{3}\right) \delta 8.35$ (dd, $J=$ 7.5, 1.6 Hz, 1H, ArH), 7.82 (s, 1H, NCHCI), 7.48 (t, $J=7.3 \mathrm{~Hz}, 1 \mathrm{H}, \operatorname{Ar} H), 7.40$ (d, $J=9.0 \mathrm{~Hz}, 1 \mathrm{H}$, $\operatorname{Ar} H), 7.27(\mathrm{~m}, 1 \mathrm{H}, \operatorname{Ar} H), 7.04(\mathrm{dd}, J=9.0,2.4 \mathrm{~Hz}, 1 \mathrm{H}, \operatorname{Ar} H), 6.84(\mathrm{~d}, J=8.3 \mathrm{~Hz}, 1 \mathrm{H}, \operatorname{Ar} H), 6.79$ $(\mathrm{d}, J=2.3 \mathrm{~Hz}, 1 \mathrm{H}, \mathrm{ArH}), 3.99\left(\mathrm{~s}, 3 \mathrm{H}, \mathrm{CH}_{3} \mathrm{~N}\right), 3.78\left(\mathrm{~s}, 3 \mathrm{H}, \mathrm{OCH}_{3}\right) .{ }^{13} \mathbf{C} \mathbf{N M R}\left(101 \mathrm{MHz}, \mathrm{CDCl}_{3}\right) \delta$ $167.1,156.4,138.9,133.3,132.5,132.5,130.5,130.1,125.2,116.0,114.8,111.7,100.8,77.4$, 55.8, 34.0 (the signal for one aromatic $C$ could not be resolved). HR-ESI-MS $408.0093\left([\mathrm{M}+\mathrm{H}]^{+}\right.$, $\mathrm{C}_{17} \mathrm{H}_{15} \mathrm{INO}_{3}{ }^{+}$calc. for 408.0091$)$. The structure of the obtained regioisomer was assigned by NMR correlation to compound 25.

\section{1-(3-5-Fluoro-1-methyl-1H-indole)-1H-1 $1 \lambda_{3}$-benzo[b]iodo-3(2H)-one (28)}<smiles>Cn1cc(I2COC(=O)c3ccccc32)c2cc(F)ccc21</smiles>

28

Following procedure A: starting from 5-fluoro-1-methyl-1 $H$-indole 108 (149 mg, $1.00 \mathrm{mmol}$ ), after 16 hours 1-(3-5-fluoro-1-methyl- $1 \mathrm{H}$ indole)- $1 H$ - $1 \lambda_{3}$-benzo[b]iodo-3(2H)-one 28 (336 mg, $0.850 \mathrm{mmol}, 85 \%$ yield) was obtained as an yellow foam. Rf: 0.3 (DCM:MeOH 9:1). IR v 3083 (w), 2952 (w), 1717 (w), 1601 (s), 1557 (m), 1503 (m), 1485 (m), 1438 (w), 1338 (m), 1242 (m), 1193 (m), 1121 (m), 1032 (w), 1005 (w), $850(\mathrm{~m}) .{ }^{1} \mathbf{H}$ NMR $\left(400 \mathrm{MHz}, \mathrm{CD}_{3} \mathrm{OD}\right) \delta 8.14(\mathrm{dd}, J=7.6,1.7 \mathrm{~Hz}, 1 \mathrm{H}, \mathrm{Ar} H), 8.01$ (s, 1H, NCHCI), 7.57 (ddd, $J=8.8,4.2,0.8 \mathrm{~Hz}, 1 \mathrm{H}, \operatorname{Ar} H), 7.49$ (td, $J=7.4,1.0 \mathrm{~Hz}, 1 \mathrm{H}, \operatorname{Ar} H$ ), 7.30 (ddd, $J=8.3$, 7.2, $1.7 \mathrm{~Hz}, 1 \mathrm{H}, \operatorname{Ar} H), 7.14-7.03$ (m, 2H, $\operatorname{Ar} H), 6.80$ (dd, J= 8.3, $0.9 \mathrm{~Hz}, 1 \mathrm{H}, \operatorname{Ar} H), 3.93$ (s, 3H, $\left.\mathrm{CH}_{3} \mathrm{~N}\right) .{ }^{13} \mathrm{C}$ NMR $\left(101 \mathrm{MHz}, \mathrm{CD}_{3} \mathrm{OD}\right) \delta 170.3,160.91(\mathrm{~d}, J=238.2 \mathrm{~Hz}), 142.6,135.9,135.1$, 134.4, 133.2, 131.7, 131.40 (d, $J=10.7 \mathrm{~Hz}), 127.7,116.8,113.71(\mathrm{~d}, J=9.8 \mathrm{~Hz}), 113.47$ (d, $J=$ $26.7 \mathrm{~Hz}), 105.67(\mathrm{~d}, J=25.3 \mathrm{~Hz}), 77.5,34.3 .{ }^{19} \mathbf{F}$ NMR $(376 \mathrm{MHz}, \mathrm{CDCl} 3) \delta$-119.8. HR-ESIMS $395.9894\left([\mathrm{M}+\mathrm{H}]^{+}, \mathrm{C}_{16} \mathrm{H}_{12} \mathrm{FINO}_{2}{ }^{+}\right.$; calc. for 395.9891). The structure of the obtained regioisomer was assigned by NMR correlation to compound 25. 
<smiles>Cn1cc(I2COC(=O)c3ccccc32)c2cc(Cl)ccc21</smiles>

29

Following procedure A: starting from 5-chloro-1-methyl-1 $H$-indole $\mathbf{1 0 9}$ (166 mg, $1.00 \mathrm{mmol})$, after 16 hours 1-(3-5-chloro-1-methyl-1Hindole)- $1 H-1 \lambda_{3}$-benzo[ $\left.b\right]$ iodo-3(2H)-one 29 (256 mg, $0.622 \mathrm{mmol}, 62 \%$ yield) was obtained as an orange amorphous solid. Rf: 0.4 (DCM:MeOH 9:1). IR v 3095 (w), 2953 (w), 1605 (s), 1556 (m), 1505 (m), $1438(\mathrm{~m}), 1388(\mathrm{~m}), 1370$ (m), 1260 (s), 1226 (m), 1164 (m), 1144 (m), 1115 (w), 1070 (w), 1032 (s), 1004 (w), 837 (w). ${ }^{1} \mathbf{H}$ NMR (400 MHz, $\left.\mathrm{CD}_{2} \mathrm{Cl}_{2}\right) \delta 8.20$ (d, J= $7.4 \mathrm{~Hz}, 1 \mathrm{H}, \mathrm{Ar} H), 7.78$ (s, 1H, NCHCI), 7.38 (d, J=8.7 Hz, 1H, ArH), $7.34-7.22$ (m, 3H, ArH), $7.17(\mathrm{t}, J=7.7 \mathrm{~Hz}, 1 \mathrm{H}, \mathrm{ArH}), 6.68(\mathrm{~d}, J=8.2 \mathrm{~Hz}, 1 \mathrm{H}, \mathrm{ArH}), 3.87$ (s, 3H, $\left.\mathrm{CH}_{3} \mathrm{NCHCI}\right) .{ }^{13} \mathbf{C}$ NMR (101 MHz, MeOD) $\delta$ 170.3, 142.5, 137.8, 135.1, 134.4, 133.2, 131.7, 131.7, 129.6, 127.8, 125.4, 120.0, 116.8, 113.7, 77.5, 34.2 HR-ESI-MS $411.9603\left([\mathrm{M}+\mathrm{H}]^{+}, \mathrm{C}_{16} \mathrm{H}_{12} \mathrm{ClINO}_{2}{ }^{+}\right.$; calc. for 411.9596). The structure of the obtained regioisomer was assigned by NMR correlation to compound 25.

1-(3-5-Iodo-1-methyl-1 $H$-indole)-1 $H$-1 $1 \lambda_{3}$-benzo $[b]$ iodo-3(2H)-one (30)<smiles>Cn1cc(I)c2cc(I)ccc21</smiles>

30

Following procedure A: starting from 5-iodo-1-methyl- $1 H$-indole 110 (257 mg, $1.00 \mathrm{mmol})$, after 16 hours 1-(3-5-iodo-1-methyl-1H-indole)$1 H-1 \lambda_{3}$-benzo[b]iodo-3(2H)-one 30 (380 $\mathrm{mg}, 0.755 \mathrm{mmol}, 76 \%$ yield) was obtained as a yellow amorphous solid. NB: the reagent is unstable in acidic deuterated solvents and it decompose in short time, we recommend the immediate use after the synthesis. The proton NMR presents about 21\% of the open protonated form. Rf: 0.3 (DCM:MeOH 9:1). IR $v 3092$ (w), 3061 (w), 1600 (s), 1584 (m), 1557 (m), 1503 (m), 1436 (w), 1422 (w), 1371 (m), 1265 (s), 1245 (s), 1225 (m), 1163 (m), 1113 (w), 1031 (s), 1004 (w), 836 (w). ${ }^{1} \mathbf{H}$ NMR (400 MHz, $\mathrm{CDCl}_{3}$ ) $\delta 8.24$ (m, 1H, ArH), 7.83 (s, 1H, NCHCI), $7.58-7.47$ (m, 2H, $\mathrm{ArH}), 7.26$ (m, 1H, $\mathrm{Ar} H+\mathrm{CDCl}_{3}$ ), 7.21 - $7.18(\mathrm{~m}, 2 \mathrm{H}, \mathrm{ArH}), 6.67(\mathrm{~d}, J=8.1 \mathrm{~Hz}, 1 \mathrm{H}, \mathrm{ArH}), 3.87\left(\mathrm{~s}, 3 \mathrm{H}, \mathrm{CH}_{3} \mathrm{~N}\right) .{ }^{13} \mathbf{C}$ NMR $(101 \mathrm{MHz}$, $\left.\mathrm{CDCl}_{3}\right) \delta 168.6,140.5,136.8,133.7,132.6,132.3,131.4,130.3,128.1,126.0,122.3,119.1,115.7$, 112.9, 86.1, 34.0. HR-ESI-MS $503.8952\left([\mathrm{M}+\mathrm{H}]^{+}, \mathrm{C}_{16} \mathrm{H}_{12} \mathrm{I}_{2} \mathrm{NO}_{2}{ }^{+}\right.$; calc. for 503.8952). The structure of the obtained regioisomer was assigned by NMR correlation to compound 25. 


\section{1-(3-1-Methyl-5-(4,4,5,5-tetramethyl-1,3,2-dioxaborolan-2-yl)-1H-indole)-1H-1$\lambda_{3}$ -}

benzo $[b]$ iodo-3(2H)-one (31)<smiles>Cn1cc(I2COC(=O)c3ccccc32)c2cc(Cc3ccccc3)ccc21</smiles>

31

Following procedure A: starting from commercially available 1-methyl5-(4,4,5,5-tetramethyl-1,3,2-dioxaborolan-2-yl)-1H-indole (149 mg, $1.00 \mathrm{mmol})$, after 16 hours 1-(3-1-methyl-5-(4,4,5,5-tetramethyl-1,3,2dioxaborolan-2-yl)-1H-indole)-1H-1 $\lambda_{3} \quad$-benzo[b]iodo-3(2H)-one 31 (276 mg, $0.549 \mathrm{mmol}, 54 \%$ yield) was obtained as an orange amorphous solid. Rf: 0.46 (DCM:MeOH 9:1). IR v 3095 (w), 2979 (w), 1611 (s), 1558 (w), 1507 (w), 1436 (w), 1360 (s), 1303 (w), 1263 (w), 1142 (s), 1114 (w), 1074 (w), 970 (w), 861 (w). ${ }^{1} \mathbf{H}$ NMR (400 MHz, $\left.\mathrm{CD}_{2} \mathrm{Cl}_{2}\right) \delta 8.32(\mathrm{dd}, J=7.5,1.7 \mathrm{~Hz}, 1 \mathrm{H}, \mathrm{Ar} H), 7.93(\mathrm{~s}, 1 \mathrm{H}$, NCHCI), 7.81 (dd, $J=8.4,1.1 \mathrm{~Hz}, 1 \mathrm{H}, \mathrm{Ar} H), 7.74$ (s, 1H, CCHCBPin), $7.59-7.48$ (m, 2H, ArH), 7.31 (ddd, $J=8.6,7.1,1.7 \mathrm{~Hz}, 1 \mathrm{H}, \operatorname{Ar} H), 6.85$ (dd, $J=8.3,0.9 \mathrm{~Hz}, 1 \mathrm{H}, \operatorname{Ar} H), 3.99$ (s, 3H, NCH $)$, 1.30 (s, 12H, CBPin). ${ }^{13} \mathrm{C}$ NMR (101 MHz, $\left.\mathrm{CD}_{2} \mathrm{Cl}_{2}\right) \delta 167.0,140.1,139.6,134.1,133.8,132.6$, 131.0, 130.5, 129.5, 127.6, 126.0, 117.1, 110.7, 84.5, 80.3, 34.4, 25.2 (one aromatic Carbon signal not resolved). HR-ESI-MS $504.0835\left([\mathrm{M}+\mathrm{H}]^{+}, \mathrm{C}_{22} \mathrm{H}_{24} \mathrm{BINO}_{4}{ }^{+}\right.$; calc. for 504.0838). The structure of the obtained regioisomer was assigned by NMR correlation to compound 25.<smiles>O=C1OI(c2cn(CCCc3ccccc3)c3ccccc23)c2ccccc21</smiles>

32

$88 \%$ yield<smiles>C=CCCn1cc(I2OC(=O)c3ccccc32)c2ccccc21</smiles>

33<smiles>O=C1OI(c2cn(CCO[AsH2])c3ccccc23)c2ccccc21</smiles>

34 $60 \%$ yield

Figure S3: Scope of Heterocyclic-BX reagents (3) 


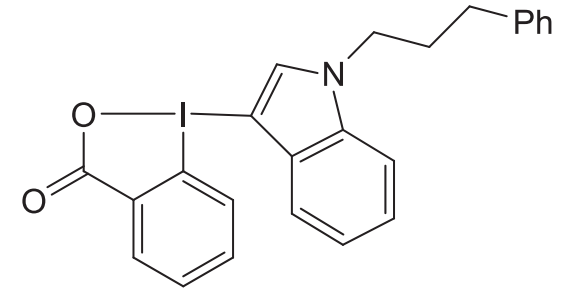

32

Following procedure A: starting from 1-(3-phenylpropyl)-indole 114 (235 mg, $1.00 \mathrm{mmol})$, after 16 hours 1-(3-1-(3phenylpropyl)- $1 H$-indole)- $1 H-1 \lambda_{3} \quad$-benzo $[b]$ iodo-3(2H)-one 32 (436 mg, $0.906 \mathrm{mmol}, 91 \%$ yield) was obtained as an orange resin. Rf: 0.45 (DCM:MeOH 9:1). IR v 3060 (w), 3026 (w), 2939 (w), 1717 (w), 1601 (s), 1551 (m), 1498 (m), 1455 (w),

$1364(\mathrm{w}), 1245$ (w), $1165(\mathrm{w}), 1005$ (w), 828 (m). ${ }^{1} \mathbf{H} \mathbf{~ N M R}\left(400 \mathrm{MHz}, \mathrm{CDCl}_{3}\right) \delta 8.37$ (dd, $J=7.5$, $1.7 \mathrm{~Hz}, 1 \mathrm{H}, \operatorname{Ar} H), 7.86$ (s, 1H, NCHCI), $7.54-7.36$ (m, 4H, ArH), $7.33-7.19$ (m, 5H, ArH), 7.18 - $7.14(\mathrm{~m}, 2 \mathrm{H}, \operatorname{Ar} H), 6.79(\mathrm{dd}, J=8.3,0.8 \mathrm{~Hz}, 1 \mathrm{H}, \mathrm{ArH}), 4.34$ (t, $J=7.2 \mathrm{~Hz}, 2 \mathrm{H}, \mathrm{NCH}_{2}$ ), 2.73 (t, $\left.J=7.5 \mathrm{~Hz}, 2 \mathrm{H}, \mathrm{CH}_{2} \mathrm{Ph}\right), 2.35\left(\mathrm{~m}, 2 \mathrm{H}, \mathrm{CH}_{2}-\mathrm{CH}_{2}-\mathrm{CH}_{2}\right) .{ }^{13} \mathbf{C} \mathbf{N M R}\left(101 \mathrm{MHz}, \mathrm{CDCl}_{3}\right) \delta 166.8,140.0$, $137.8,136.8,133.4,133.2$, 132.4 130.4, 129.3, 128.6, 128.3, 126.4, 125.2, 124.1, 122.5, 120.0, 116.1, 110.9, 78.9, 46.7, 32.8, 31.1. HR-ESI-MS $482.0614\left([\mathrm{M}+\mathrm{H}]^{+}, \mathrm{C}_{24} \mathrm{H}_{21} \mathrm{INO}_{2}{ }^{+}\right.$; calc. for 482.0612). The structure of the obtained regioisomer was assigned by NMR correlation to compound 25.

\section{1-(3-1-(But-3-en-1-yl)-1H-indole)-1H-1 $\lambda_{3}$-benzo[b]iodo-3(2H)-one (33)}

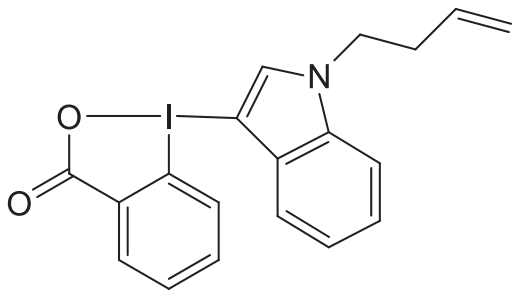

33

Following procedure A: starting from 1-(but-3-en-1-yl)-1Hindole 112 (171 mg, $1.00 \mathrm{mmol})$, after 16 hours 1-(3-1-(but-3en-1-yl)- $1 H$-indole)-1 $H$-1 $1 \lambda_{3}$-benzo[$\left.b\right]$ iodo-3(2H)-one 33 (359 $\mathrm{mg}, 0.860 \mathrm{mmol}, 86 \%$ yield) was obtained, as a yellow amorphous solid. Rf: 0.44 (DCM:MeOH 9:1). IR v 3082 (w), 1607 (s), 1557 (m), 1500 (m), 1456 (w), 1437 (w), $1389(\mathrm{w})$, 1358 (m), 1262 (w), 1160 (w), 1005 (w), 919 (w), 830 (w). ${ }^{1}$ H NMR (400 MHz, $\left.\mathrm{CDCl}_{3}\right) \delta 8.35$ (dd, $J=7.4,1.7 \mathrm{~Hz}, 1 \mathrm{H}, \mathrm{Ar} H), 7.91$ (s, 1H, NCHCI), 7.54 (m, 1H, ArH), 7.49 (td, J=7.3, $0.9 \mathrm{~Hz}$, 1H, $\operatorname{Ar} H), 7.46-7.39$ (m, 2H, ArH), $7.32-7.19$ (m, 2H, ArH), 6.73 (dd, J=8.3, 0.9 Hz, 1H, ArH), 5.82 (ddt, $\left.J=17.1,10.3,6.9 \mathrm{~Hz}, 1 \mathrm{H}, \mathrm{NCH}_{2} \mathrm{CH}_{2} \mathrm{CH}=\mathrm{CH}_{2}\right), 5.12-4.97(\mathrm{~m}, 2 \mathrm{H}$, $\left.\mathrm{NCH}_{2} \mathrm{CH}_{2} \mathrm{CH}=\mathrm{CH}_{2}\right), 4.41\left(\mathrm{t}, \mathrm{J}=6.9 \mathrm{~Hz}, 2 \mathrm{H}, \mathrm{NCH}_{2}\right), 2.71\left(\mathrm{~m}, 2 \mathrm{H}, \mathrm{CH}_{2}\right) .{ }^{13} \mathbf{C} \mathbf{N M R}(101 \mathrm{MHz}$, $\left.\mathrm{CDCl}_{3}\right) \delta 166.8,137.9,136.7,133.6,133.4,133.2,132.5,130.5,129.4,125.2,124.2,122.5,120.0$, 118.6, 116.2, 110.9, 79.0, 46.9, 34.2. HR-ESI-MS $418.0294\left([\mathrm{M}+\mathrm{H}]^{+}, \mathrm{C}_{19} \mathrm{H}_{17} \mathrm{INO}_{2}{ }^{+}\right.$; calc. for 418.0299). The structure of the obtained regioisomer was assigned by NMR correlation to compound 25. 
<smiles>O=C1OI(c2cn(CCO[Na])c3ccccc23)c2ccccc21</smiles>

34

Following procedure A: starting from 1-(2((triisopropylsilyl)oxy)ethyl)- $1 H$-indole 113 (318 mg, 1.00 mmol), after 16 hours 1-(3-1-(2-((triisopropylsilyl)oxy)ethyl)$1 H$-indole)- $1 H$-1 $1 \lambda_{3}$-benzo[b]iodo-3(2H)-one 34 (873 mg, $0.929 \mathrm{mmol}, 60 \%$ yield) was obtained as an orange oil. Rf: 0.40 (DCM:MeOH 9:1). IR v 2942 (w), 2890 (w), 2865 (m), $1716(\mathrm{w}), 1604$ (s), 1555 (w), 1500 (w), 1458 (w), 1358 (m), 1249 (m), 1169 (w), 1115 (w), 1015 (w), 883 (m), 831 (m). ${ }^{1} \mathbf{H}$ NMR $\left(400 \mathrm{MHz}, \mathrm{CDCl}_{3}\right) \delta 8.47$ (d, J=7.5 Hz, 1H, ArH), $7.99(\mathrm{~s}, 1 \mathrm{H}$, NCHCI), $7.65(\mathrm{~d}, J=8.5 \mathrm{~Hz}, 1 \mathrm{H}, \operatorname{Ar} H), 7.59$ (t, $J=7.5 \mathrm{~Hz}, 1 \mathrm{H}, \operatorname{Ar} H), 7.51-7.45$ (m, 2H, ArH), $7.35(\mathrm{~m}, 2 \mathrm{H}, \mathrm{Ar} H), 6.94$ (d, $J=8.3 \mathrm{~Hz}, 1 \mathrm{H}, \mathrm{Ar} H), 4.54$ (t, $\left.J=5.0 \mathrm{~Hz}, 2 \mathrm{H}, C_{2}\right), 4.20$ (t, $J=5.0$ $\left.\mathrm{Hz}, 2 \mathrm{H}, \mathrm{CH}_{2}\right), 1.09\left(\mathrm{dd}, J=8.7,5.6 \mathrm{~Hz}, 3 \mathrm{H}, \mathrm{SiCH}\left(\mathrm{CH}_{3}\right)_{2}\right), 1.01$ (d, $\left.J=7.1 \mathrm{~Hz}, 18 \mathrm{H}, \operatorname{SiCH}\left(\mathrm{CH}_{3}\right)_{2}\right)$. ${ }^{13} \mathrm{C}$ NMR $\left(101 \mathrm{MHz}, \mathrm{CDCl}_{3}\right) \delta 167.0,138.8,137.1,133.2,133.2,132.4,130.4,129.1,125.3$, 124.0, 122.4, 119.7, 115.8, 111.0, 78.3, 62.3, 49.8, 17.7, 11.6. HR-ESI-MS 564.1431 ([M+H] $]^{+}$, $\mathrm{C}_{26} \mathrm{H}_{35} \mathrm{INO}_{3} \mathrm{Si}^{+}$; calc. for 564.1425). The structure of the obtained regioisomer was assigned by NMR correlation to compound 25. 
<smiles>Cn1cccc1I1OC(=O)c2ccccc21</smiles>

$35 a$<smiles>Cn1ccc(I2OC(=O)c3ccccc32)c1</smiles>

$35 b$

$95 \%$ yield

1:1 ratio C2:C3<smiles>O=C1OI(c2ccccc2)c2ccccc21</smiles><smiles>O=C1OI(c2ccn(Cc3ccccc3)c2)c2ccccc21</smiles>

$36 a$

$85 \%$ yield

$36 b$

1:3 ratio $\mathrm{C2}: \mathrm{C3}$<smiles>O=C1OI(c2cc[nH]c2)c2ccccc21</smiles>

37

$72 \%$ yield

Figure S4: Scope of Heterocyclic-BX reagents (4)

1-(2-1-Methyl-1H-pyrrole)-1 $H$-1 $1 \lambda_{3}$-benzo[b]iodo-3(2H)-one (35a) and 1-(3-1-methyl-1Hpyrrole)-1H-1 $\lambda_{3}$-benzo[b]iodo-3(2H)-one (35b).

Following procedure A: starting from commercially available 1-methyl- $1 H$ pyrrole $12(0.890 \mathrm{ml}, 1.00 \mathrm{mmol})$, after 12 hours 1-(2-1-methyl-1H-pyrrole)-1H-1 $\lambda_{3}$ benzo $[b]$ iodo-3(2H)-one 35a and 1-(3-1methyl-1H-pyrrole)- $1 H$-1 $1 \lambda_{3}$-benzo[b]iodo- 
$3(2 H)$-one $35 \mathbf{b}$ were obtained as a 1:1 mixture (310 $\mathrm{mg}, 0.948 \mathrm{mmol}$, overall yield $95 \%)$ as an offwhite, sticky amorphous solid. Rf: 0.5 (DCM:MeOH 9:1). The two compounds were separated by slow flash column chromatography (EtOAc:MeOH 9:1). The structure of the obtained regioisomers were assigned by NMR correlation to compound $\mathbf{3 7}$.<smiles>Cn1cccc1I1COC(=O)c2ccccc21</smiles>

$35 a$

1-(2-1-methyl-1 $H$-pyrrole)-1H-1 $\lambda_{3}$-benzo[b]iodo-3(2H)-one 35a (152 mg, $0.465 \mathrm{mmol}, 47 \%$ yield; off-white, sticky amorphous solid) Rf: 0.3 (EtOAc:MeOH 9:1). IR $v 3415$ (w), 3105 (w), 3049 (w), 2950 (w), 1604 (s), $1584(\mathrm{~m}), 1558(\mathrm{w}), 1508$ (w), 1437 (w), 1346 (m), 1288 (m), $1223(\mathrm{w})$, 1149 (w), 1091 (w), 1047 (w), 1005 (w), 829 (m). ' H NMR (400 MHz, $\left.\mathrm{CD}_{3} \mathrm{OD}\right) \delta 8.24(\mathrm{dd}, J=7.5,1.6 \mathrm{~Hz}, 1 \mathrm{H}, \mathrm{Ar} H), 7.65(\mathrm{td}, J=7.4,1.0 \mathrm{~Hz}, 1 \mathrm{H}$, $\operatorname{Ar} H), 7.55(\mathrm{~m}, 1 \mathrm{H}, \operatorname{Ar} H), 7.27(\mathrm{t}, J=2.1 \mathrm{~Hz}, 1 \mathrm{H}, \operatorname{Ar} H), 7.01(\mathrm{dd}, J=3.9,1.6 \mathrm{~Hz}, 1 \mathrm{H}, \operatorname{Ar} H), 6.72$ $(\mathrm{dd}, J=8.3,1.0 \mathrm{~Hz}, 1 \mathrm{H}, \mathrm{ArH}), 6.43(\mathrm{dd}, J=3.9,2.1 \mathrm{~Hz}, 1 \mathrm{H}, \mathrm{ArH}), 3.78\left(\mathrm{~s}, 1 \mathrm{H}, \mathrm{NCH}_{3}\right) .{ }^{13} \mathbf{C}$ NMR (101 MHz, $\left.\mathrm{CD}_{3} \mathrm{OD}\right) \delta 170.1,135.5,134.2,133.2,131.9,131.4,127.7,126.6,119.4,112.9,96.0$, 37.4. HR-ESI-MS $327.9842\left([\mathrm{M}+\mathrm{H}]^{+}, \mathrm{C}_{12} \mathrm{H}_{11} \mathrm{INO}_{2}{ }^{+}\right.$; calc. for 327.9829). DSC-analysis was performed on compound 35a: see par.5 of Supplementary informations.<smiles>Cn1ccc(I2COC(=O)c3ccccc32)c1</smiles>

$35 b$

1-(3-1-methyl-1H-pyrrole)-1H-1 $\lambda_{3}$-benzo[b]iodo-3(2H)-one 35b (158 mg, 0.483 mmol, 48\% yield; off-white, sticky amorphous solid). Rf: 0.25 (EtOAc:MeOH 9:1). IR v $3447(w), 3106(w), 2947(w), 2863(w)$, 1603 (s), 1591 (m), 1558 (m), $1512(\mathrm{~m}), 1437$ (w), 1354 (m), $1294(\mathrm{w})$, 1110 (m), 1083 (w), 1007 (w), 829 (m). ${ }^{1} \mathbf{H}$ NMR (400 MHz, CD $\left.{ }_{3} \mathrm{OD}\right)$

$\delta 8.15(\mathrm{dd}, J=7.5,1.7 \mathrm{~Hz}, 1 \mathrm{H}, \operatorname{Ar} H), 7.53(\mathrm{td}, J=7.3,1.1 \mathrm{~Hz}, 1 \mathrm{H}, \operatorname{Ar} H), 7.49-7.40$ (m, 2H, $\operatorname{Ar} H), 7.04-6.98$ (m, 2H, ArH), $6.58(\mathrm{~d}, J=1.2 \mathrm{~Hz}, 1 \mathrm{H}, \operatorname{Ar} H), 3.85$ (s, 3H, NMe). ${ }^{13} \mathbf{C}$ NMR (101 $\left.\mathrm{MHz}, \mathrm{CD}_{3} \mathrm{OD}\right) \delta 170.0,134.9,134.2,133.4,132.8,131.5,127.9,127.7,117.4,116.6,82.8,37.1$. HR-ESI-MS $327.9831\left([\mathrm{M}+\mathrm{H}]^{+}, \mathrm{C}_{12} \mathrm{H}_{11} \mathrm{INO}_{2}{ }^{+}\right.$; calc. for 327.9829). DSC-analysis was performed on compound 35b: see par.5 of Supplementary informations.

1-(2-1-benzyl-1H-pyrrole)-1H-1 $\lambda_{3}$-benzo[b]iodo-3(2H)-one (36a) and 1-(3-1-benzyl-1Hpyrrole)-1H-1 $\lambda_{3}$-benzo $[b]$ iodo-3(2H)-one (36b) 
<smiles>O=C1OI(c2ccccc2)c2cccn2Cc2ccccc21</smiles>

$36 \mathbf{a}$<smiles>O=C1OI(c2ccn(Cc3ccccc3)c2)c2ccccc21</smiles>

$36 \mathrm{~b}$

Following procedure A: starting from commercially available 1-benzyl- $1 H$ pyrrole $(0.890 \mathrm{ml}, 1.00 \mathrm{mmol})$, after 12 hours 1-(2-1-benzyl-1H-pyrrole)-1H$1 \lambda_{3}$-benzo[b]iodo-3(2H)-one $\mathbf{3 6 a}$ and 1 (3-1-benzyl-1H-pyrrole)-1H-1 $\lambda_{3}$ benzo $[b]$ iodo-3 $(2 H)$-one $\mathbf{3 6 b}$ were obtained in 3:1 mixture (345 mg, $0.856 \mathrm{mmol}$, overall yield 86\%), as a colorless amorphous solid. Rf: 0.7 (DCM:MeOH 9:1). The two compounds were separated by slow flash column chromatography (EtOAc:MeOH 9:1). The structure of the obtained regioisomers were assigned by NMR correlation to compound 37.<smiles>O=C1OI(c2ccccc2)c2ccccc21</smiles>

$36 \mathbf{a}$ 1-(2-1-benzyl-1H-pyrrole)-1H-1 $\lambda_{3}$-benzo[b]iodo-3(2H)-one 36a (85.0 mg, $0.211 \mathrm{mmol}, 21 \%$ yield); colorless foam. Rf: 0.5 (EtOAc:MeOH 9:1). IR v 3109 (w), 3064 (w), 2968 (w), 2875 (w), 1609 (s), 1585 (m), 1558 (w), 1503 (w), $1456(w), 1440(w), 1357(\mathrm{~m}), 1277(\mathrm{w}), 1103(\mathrm{~m}), 1079(\mathrm{w}), 1032(\mathrm{w})$, 1031 (w), $830(\mathrm{w}) .{ }^{1} \mathbf{H}$ NMR (400 MHz, 2:1 mixture $C_{3} O D: C_{6} D_{6}$, referered to $\left.\mathrm{CD}_{3} \mathrm{OD}\right) \delta 8.18(\mathrm{dd}, J=7.5,1.6 \mathrm{~Hz}, 1 \mathrm{H}, \mathrm{Ar} H), 7.28(\mathrm{t}, J=7.4$ $\mathrm{Hz}, 1 \mathrm{H}, \operatorname{Ar} H), 7.10(\mathrm{t}, J=2.2 \mathrm{~Hz}, 1 \mathrm{H}, \operatorname{Ar} H), 6.92(\mathrm{~m}, J=7.6,2.9 \mathrm{~Hz}, 6 \mathrm{H}$, $\left.\operatorname{Ar} H+\mathrm{C}_{6} \mathrm{D}_{6}\right), 6.71(\mathrm{dd}, J=3.9,1.7 \mathrm{~Hz}, 1 \mathrm{H}, \operatorname{Ar} H), 6.35(\mathrm{t}, J=3.4 \mathrm{~Hz}, 1 \mathrm{H}, \operatorname{Ar} H), 6.23(\mathrm{~d}, J=8.3$ $\mathrm{Hz}, 1 \mathrm{H}, \mathrm{Ar} H), 4.90\left(\mathrm{~s}, 2 \mathrm{H}, \mathrm{NCH} \mathrm{H}_{2} \mathrm{Ph}\right) .{ }^{13} \mathbf{C} \mathbf{N M R}\left(101 \mathrm{MHz}, 2: 1\right.$ mixture $\mathrm{CD}_{3} \mathrm{OD}: \mathrm{C}_{6} D_{6}$, referered to $\left.C D_{3} O D\right) \delta 169.8,136.9,134.6,132.7,131.2,131.1,129.5,129.0,128.5,127.2,119.2,112.9$, 94.8, 54.7 (two Carbon signals under the deuterated benzene). HR-ESI-MS $404.0140\left([\mathrm{M}+\mathrm{H}]^{+}\right.$, $\mathrm{C}_{18} \mathrm{H}_{15} \mathrm{INO}_{2}^{+}$; calc. for 404.0142).

1-(3-1-benzyl-1H-pyrrole)-1H-1 $\lambda_{3} \quad$-benzo[b]iodo-3(2H)-one 36b (260 mg, $0.645 \mathrm{mmol}, 65 \%$ yield); colorless foam. Rf: 0.46 (EtOAc:MeOH 9:1). IR v 3409 (w), 3114 (w), 2971 (w), 1609 (s), $1585(\mathrm{~m}), 1558(\mathrm{w}), 1456(\mathrm{w}), 1438(\mathrm{w}), 1365$ (m), 1277 (s), 1160 (w), 1079 (w), 1032 (m), 835 (w). ${ }^{1}$ H NMR (400 MHz, 
2:1 mixture $C D_{3} O D: C_{6} D_{6}$, refered to $\left.C D_{3} O D\right) \delta 8.29(\mathrm{dd}, J=7.5,1.7 \mathrm{~Hz}, 1 \mathrm{H}, \mathrm{Ar} H), 7.36(\mathrm{t}, J=$ $7.3 \mathrm{~Hz}, 1 \mathrm{H}, \mathrm{Ar} H), 7.30-7.20$ (m, 3H ArH $\left.+\mathrm{C}_{6} \mathrm{D}_{6}\right), 7.18-7.08$ (m, 3H, $\left.\mathrm{ArH}\right), 6.97$ (d, J=2.0 Hz, $1 \mathrm{H}, \operatorname{Ar} H), 6.83-6.78(\mathrm{~m}, 2 \mathrm{H}, \mathrm{ArH}), 6.30$ (dd, $J=3.0,1.7 \mathrm{~Hz}, 1 \mathrm{H}, \mathrm{Ar} H), 4.93\left(\mathrm{~s}, 2 \mathrm{H}, \mathrm{NCH}_{2} \mathrm{Ph}\right)$. ${ }^{13} \mathrm{C}$ NMR (101 MHz, 2:1 mixture $C D_{3} O D: C_{6} D_{6}$, refered to $\left.C D_{3} O D\right) \delta 168.7,136.8,133.5,133.0$, $131.8,130.9,130.3,128.8,128.1,127.4,126.2,125.5,116.3,115.3,82.4,53.5$. HR-ESI-MS $404.0140\left([\mathrm{M}+\mathrm{H}]^{+}, \mathrm{C}_{18} \mathrm{H}_{15} \mathrm{INO}_{2}{ }^{+}\right.$; calc. for 404.0142).

\section{1-(3-1H-Pyrrole)-1H-1 $1 \lambda_{3}$-benzo[b]iodo-3(2H)-one (37)}<smiles>O=C1OI(c2cc[nH]c2)c2ccccc21</smiles>

37

Following procedure A: starting from 1-(tert-butyldimethylsilyl)-1Hpyrrole 111 (181 mg, $1.00 \mathrm{mmol})$ and using $\mathrm{Sc}(\mathrm{OTf})_{3}$ as the Lewis Acid (20 mol\%), after 16 hours 1-(3-1H-pyrrole)- $1 H$ - $1 \lambda_{3}$-benzo[b]iodo-3(2H)one 9 n (225 mg, $0.719 \mathrm{mmol}, 72 \%$ yield) was obtained as a slightly brown solid. Rf: 0.5 (DCM:MeOH 9:1). Mp: $147^{\circ} \mathrm{C}$ (decomposition). IR $v 3484$ (w), 1607 (w), 1558 (w), 1439 (w), 1397 (w), 1260 (s), 1236 (s), 1174 (s), 1084 (w), 1050 (m), $1038(\mathrm{~m}), 903(\mathrm{w}), 882(\mathrm{w}) .{ }^{1} \mathbf{H}$ NMR (400 MHz, MeOD) $\delta 8.40(\mathrm{dd}, J=7.5,1.7 \mathrm{~Hz}, 1 \mathrm{H}, \mathrm{Ar} H)$, $7.72(\mathrm{~d}, J=7.4 \mathrm{~Hz}, 1 \mathrm{H}, \operatorname{Ar} H), 7.68-7.59$ (m, 2H, ArH), 7.23 (t, $J=2.4 \mathrm{~Hz}, 1 \mathrm{H}, \operatorname{Ar} H), 7.14$ (d, $J$ $=8.2 \mathrm{~Hz}, 1 \mathrm{H}, \mathrm{ArH}), 6.74(\mathrm{dd}, J=2.8,1.5 \mathrm{~Hz}, 1 \mathrm{H}, \mathrm{ArH})\left(\mathrm{NH}\right.$ signal exchanges with MeOD). ${ }^{13} \mathbf{C}$ NMR (101 MHz, MeOD) $\delta 170.3,135.0,134.4$, 132.9, 131.5, 130.4, 128.0, 123.7, 117.3, 115.9, 83.4. HRMS (ESI) calcd for $\mathrm{C}_{11} \mathrm{H}_{9} \mathrm{INO}_{2}{ }^{+}[\mathrm{M}+\mathrm{H}]^{+} 313.9673$; found 313.9673. The structure of the reagent was assigned based on X-Ray diffraction (CCDC number 1541174). 
<smiles></smiles><smiles>Cn1ccc(I2OC(C(F)(F)F)(C(F)(F)F)c3ccccc32)c1</smiles>

$16 a$

$1: 1$

$90 \%$ yield<smiles>Cn1cccc1I1C(c2ccccc2)OC1(C)C</smiles>

$38 a$<smiles>Cn1ccc(I2OC(C)(C)c3ccccc32)c1</smiles>

$38 b$

$16 b$

$1: 9$

$91 \%$ yield

Figure S5: Scope of Heterocyclic-BX reagents (5)

\section{1-(2-1-Methyl-1H-pyrrole)-3,3-bis(trifluoromethyl)-1,3-dihydro-1 $\lambda^{3}$-benzo $[d][1,2]$ iodaoxole}<smiles></smiles>

$16 a$<smiles>Cn1ccc(I2OC(C(F)(F)F)(C(F)(F)F)c3ccccc32)c1</smiles>

$16 b$ Following procedure B: starting from commercially available 1-methyl- $1 H$ pyrrole 12 (17.8 $\mu 1,0.200 \mathrm{mmol})$ and 1 acetoxy-1,3-dihydro-3,3-

bis(trifluoromethyl)-1,2-benziodoxole 18 (94.0 mg, 0.220 mmol, 1.10 equiv.), after 12 hours 1-(2-1-methyl-1H-pyrrole)-3,3-bis(trifluoromethyl)-1,3-dihydro-1 $\lambda^{3}$ benzo $[d][1,2]$ iodaoxole 16a and 1-(3-1-methyl-1H-pyrrole)-3,3-bis(trifluoromethyl)-1,3-dihydro$1 \lambda^{3}$-benzo[ $\left.d\right][1,2]$ iodaoxole $\mathbf{1 6 b}$ were obtained in $1: 1$ mixture $(81.5 \mathrm{mg}, 182 \mathrm{mmol}$, overall yield 90\%), as a slightly grey amorphous solid. Rf: 0.5 (DCM:MeOH 9:1). The two compounds were separated by slow flash column chromatography (EtOAc:MeOH 20:1). The structure of the obtained regioisomers were assigned by NMR correlation to compound 37. 
<smiles></smiles>

$16 a$ 1-(2-1-methyl-1H-pyrrole)-3,3-bis(trifluoromethyl)-1,3-dihydro-1 $\lambda_{3}$ benzo[ $[d][1,2]$ iodaoxole 16a $(41.2 \mathrm{mg}, 92.0 \mu \mathrm{mol}, 45 \%$ yield $)$; colorless foam. Rf: 0.50 (EtOAc:MeOH 9:1). IR $v 3734$ (w), 3702 (w), 3628 (w), $1716(\mathrm{w}), 1509$ (w), $1459(\mathrm{w}), 1288$ (m), 1265 (s), $1214(\mathrm{~m}), 1181$ (s), 1158 (s), 966 (m), 951 (m), 914 (w). ${ }^{1} \mathbf{H}$ NMR (400 MHz, $\left.\mathrm{CDCl}_{3}\right) \delta 7.86$ (dd, $J=7.7,1.3 \mathrm{~Hz}, 1 \mathrm{H}, \operatorname{Ar} H), 7.57(\mathrm{td}, J=7.4,1.1 \mathrm{~Hz}, 1 \mathrm{H}, \operatorname{Ar} H), 7.41$ (ddd, $J=8.5,7.1,1.5 \mathrm{~Hz}, 1 \mathrm{H}, \mathrm{Ar} H), 6.97$ (dd, $J=2.7,1.6 \mathrm{~Hz}, 1 \mathrm{H}, \mathrm{Ar} H), 6.78$ (dd, $J=3.8,1.6 \mathrm{~Hz}$, $1 \mathrm{H}, \operatorname{Ar} H), 6.63(\mathrm{dd}, J=8.3,1.1 \mathrm{~Hz}, 1 \mathrm{H}, \operatorname{Ar} H), 6.34(\mathrm{dd}, J=3.8,2.7 \mathrm{~Hz}, 1 \mathrm{H}, \operatorname{Ar} H), 3.68(\mathrm{~s}, 3 \mathrm{H}$, $\left.\mathrm{NCH}_{3}\right) .{ }^{13} \mathbf{C} \mathbf{N M R}\left(101 \mathrm{MHz}, \mathrm{CDCl}_{3}\right) \delta 132.3,131.3,130.5,130.2,128.3,126.4,124.2,122.6(\mathrm{~m})$, $114.3,111.3,102.5,81.40(\mathrm{dt}, J=57.9,29.6 \mathrm{~Hz}), 37.0$. HR-APCI-MS $449.9771\left([\mathrm{M}+\mathrm{H}]^{+}\right.$, $\mathrm{C}_{14} \mathrm{H}_{11} \mathrm{~F}_{6} \mathrm{INO}^{+}$; calc. for 449.9784). The structure of the obtained regioisomer was assigned by NMR correlation to compound 37.<smiles>Cn1ccc(I2OC(C(F)(F)F)(C(F)(F)F)c3ccccc32)c1</smiles>

$16 b$

1-(3-1-methyl-1H-pyrrole)-3,3-bis(trifluoromethyl)-1,3-dihydro$1 \lambda^{3}$-benzo[d][1,2]iodaoxole $\mathbf{1 6 b}(40.3 \mathrm{mg}, 90.0 \mu \mathrm{mol}, 45 \%$ yield $)$; slightly grey amorphous foam. Rf: 0.48 (EtOAc:MeOH 9:1). IR v 2938 (w), 2929 (w), $1718(w), 1510(w), 1464(w), 1264(\mathrm{~s}), 1181(\mathrm{~s})$, 1161 (s), 1108 (w), 966 (m), 949 (m). ${ }^{1} \mathbf{H}$ NMR (400 MHz, $\left.\mathrm{CDCl}_{3}\right) \delta$ $7.82(\mathrm{~m}, 1 \mathrm{H}, \mathrm{Ar} H), 7.52$ (ddd, $J=7.8,7.1,1.1 \mathrm{~Hz}, 1 \mathrm{H}, \operatorname{Ar} H), 7.37$ (ddd, $J=8.5,7.1,1.5 \mathrm{~Hz}, 1 \mathrm{H}, \operatorname{Ar} H), 7.08$ (dd, $J=8.3,1.1 \mathrm{~Hz}, 1 \mathrm{H}, \operatorname{Ar} H), 6.99$ (t, $J=1.9 \mathrm{~Hz}, 1 \mathrm{H}$, $\operatorname{Ar} H), 6.76(\mathrm{dd}, J=2.7,2.1 \mathrm{~Hz}, 1 \mathrm{H}, \operatorname{Ar} H), 6.42(\mathrm{dd}, J=2.8,1.7 \mathrm{~Hz}, 1 \mathrm{H}, \operatorname{Ar} H), 3.80\left(\mathrm{~s}, 3 \mathrm{H}, \mathrm{NCH}_{3}\right)$. ${ }^{13}$ C NMR $\left(101 \mathrm{MHz}, \mathrm{CDCl}_{3}\right) \delta 131.6,131.3,130.4,129.9,129.8,126.9,125.38,124.19$ (q, $J=$ $291.5 \mathrm{~Hz}), 115.77,112.69,89.21,81.47$ (p, $J=28.7 \mathrm{~Hz}), 36.65$. HR-APCI-MS 449.9771 ([M+H] $]^{+}$, $\mathrm{C}_{14} \mathrm{H}_{11} \mathrm{~F}_{6} \mathrm{INO}^{+}$; calc. for 449.9784). The structure of the obtained regioisomer was assigned by NMR correlation to compound 37. 
1-(2-1-Methyl-1H-pyrrole)-3,3-dimethyl-1,3-dihydro-1 $\lambda^{3}$-benzo[d][1,2]iodoxole (38a) and 1(3-1-methyl-1H-pyrrole)-3,3-dimethyl-1,3-dihydro-1 $\lambda^{3}$-benzo[d][1,2]iodoxole (38b)<smiles>Cn1cccc1I1COC1(C)C</smiles>

$38 \mathbf{a}$<smiles>Cn1ccc(I2COC(C)(C)c3ccccc32)c1</smiles>

$38 b$ Following procedure B: starting from commercially available 1-methyl- $1 H$ pyrrole $12(17.8 \mu 1,0.200 \mathrm{mmol})$ and 3,3dimethyl-1 $\lambda_{3}$-benzo $[d][1,2]$ iodoxol-1 $(3 H)$ yl acetate 22 (70.4 mg, $0.220 \mathrm{mmol}, 1.10$ equiv.), after 12 hours 1-(2-1-Methyl-1Hpyrrole)-3,3-dimethyl-1,3-dihydro- $1 \lambda^{3}$-benzo[ $\left.d\right][1,2]$ iodoxole $\quad \mathbf{3 8 a}$ and 1-(3-1-methyl- $1 H$ pyrrole)-3,3-dimethyl-1,3-dihydro-1 $\lambda^{3}$-benzo[ $[d][1,2]$ iodoxole $\mathbf{3 8 b}$ were obtained in $1: 9$ unseparable mixture (62.0 mg, $0.182 \mathrm{mmol}$, overall yield 91\%), as a slightly grey amorphous solid. Rf: 0.4 (DCM:MeOH 20:1). NB: the reagent is unstable in acidic deuterated solvents and it decompose in short time, we recommend the immediate use after the synthesis. The proton and carbon NMRs present about 2\% of the open protonated alcohol form. IR $v 3115$ (w), 2986 (w), 1614 (w), 1509 (w), 1455 (w), 1372 (w), 1284 (s), 1247 (s), 1225 (m), 1163 (m), 1110 (w), 1031 (s), $992(\mathrm{w}) .{ }^{1} \mathbf{H}$ NMR (400 MHz, $\mathrm{CD}_{2} \mathrm{Cl}_{2}$ ) on a maj:min (9:1) $\delta 7.53(\mathrm{~m}, 0.26 \mathrm{H}, 2 \mathrm{ArH} \mathrm{min}), 7.50$ (dd, $J=7.0,1.0 \mathrm{~Hz}, 1 \mathrm{H}, \operatorname{Ar} H m a j), 7.45$ (dd, $J=7.8,1.8 \mathrm{~Hz}, 1 \mathrm{H}, \operatorname{Ar} H m a j$ ), 7.33 (t, $J=2.0 \mathrm{~Hz}$, 1H, ArH maj), 7.28 (dtd, $J=8.7,7.0,6.5,1.8 \mathrm{~Hz}, 1.24 \mathrm{H}, \mathrm{ArH} \mathrm{maj}+2 \mathrm{H} \mathrm{ArH} \mathrm{min)} 7.23$ (dd, $J=$ 2.9, $1.7 \mathrm{~Hz}, 0.12 \mathrm{H}$, ), 7.04 (dd, $J=8.4,1.1 \mathrm{~Hz}, 1 \mathrm{H}, \operatorname{Ar} H$ maj), 6.94 (dd, $J=2.9,2.1 \mathrm{~Hz}, 1 \mathrm{H}, \operatorname{Ar} H$ maj), 6.66 (dd, $J=8.4,0.9 \mathrm{~Hz}, 0.12 \mathrm{H}, \operatorname{Ar} H \min ), 6.57$ (dd, $J=3.0,1.8 \mathrm{~Hz}, 1 \mathrm{H}, \operatorname{Ar} H$ maj), 6.48 (dd, $J=4.1,2.8 \mathrm{~Hz}, 0.12 \mathrm{H}, \mathrm{ArH} \min ), 3.85\left(\mathrm{~s}, 3.32 \mathrm{H}, \mathrm{NCH}{ }_{3} \operatorname{maj}+\min \right), 1.68\left(\mathrm{~s}, 6.73 \mathrm{H}, \mathrm{N}\left(\mathrm{CH}_{3}\right)_{2}\right.$ maj+min). Major regioisomer C3 X: ${ }^{13} \mathbf{C} \mathbf{N M R}\left(101 \mathrm{MHz}, \mathrm{CD}_{2} \mathrm{Cl}_{2}\right) \delta 146.4,133.4,131.5,131.0$, 129.0, 127.7, 127.7, 116.5, 109.9, 77.8, 75.1, 37.8, 30.8. Minor regioisomer C2 X: ${ }^{13}$ C NMR (101 $\left.\mathrm{MHz}, \mathrm{CD}_{2} \mathrm{Cl}_{2}\right) \delta 146.6,132.6,131.9,129.5,128.4,127.4,122.6,119.4,113.6,89.3,75.4,37.9$, 30.8. (the last two overlap with the major regioisomers). HR-ESI-MS $342.0350\left([\mathrm{M}+\mathrm{H}]^{+}\right.$, $\mathrm{C}_{14} \mathrm{H}_{17} \mathrm{INO}^{+}$; calc. for 342.0349). The structure of the obtained regioisomer was assigned by NMR correlation to compound 37. 
<smiles>COc1cc2c(cc1OC)I(c1cn(C)c3ccccc13)OC2=O</smiles>

39<smiles>COc1cc2c(cc1OC)I(c1cccn1C)C(=O)O2</smiles>

$40 a$<smiles>COc1cc2c(cc1OC)I(c1ccn(C)c1)OC2=O</smiles>

$40 \mathrm{~b}$

$56 \%$ yield<smiles>Cn1cccc1I1C(=O)OC1=C1C=CC=C(F)C1</smiles>

$99.5 \%$ yield<smiles>Cn1ccc(I2COC(=O)c3c(F)cccc32)c1</smiles>

$41 \mathrm{a}$

$1: 3$

41b

$63.9 \%$ yield<smiles>Cn1cccc1I1C(=O)OCc2cc([N+](=O)[O-])ccc21</smiles><smiles>Cn1ccc(I2COC(=O)c3cc([N+](=O)[O-])ccc32)c1</smiles>

$42 a$

$4: 1$

42b

$93.4 \%$ yield

Figure S6: Scope of Heterocyclic-BX reagents (6)

\section{5,6-Dimethoxy-1-(3-1-Methyl-1H-indole)- $1 H$-1 $\lambda_{3}$-benzo[b]iodo-3(2H)-one (39)}

Following procedure $\mathbf{B}$ : starting from commercially available 1-methyl1-H-indole 14 (26.2 $\mathrm{mg}, \quad 0.100 \mathrm{mmol})$ and 5,6-dimethoxy-3oxobenzo[ $d][1,2]$ iodaoxol-1(3H)-yl acetate $95(81.0 \mathrm{mg}, 0.220 \mathrm{mmol}$, 1.10 equiv.), after 16 hours 1-(3-1-methyl- $1 H$-indole)-3,3-dimethyl-1,3dihydro- $1 \lambda^{3}$-benzo $[d][1,2]$ iodoxole 39 (49.0 $\mathrm{mg}, 0.112 \mathrm{mmol}, 56 \%$ yield) was obtained as a brown foam. Rf: 0.7 (DCM:MeOH 9:1). IR $\vee 3113$ (w), 2942 (w), 1603 (s), 1499 (s), 1455 (m), 1394 (s), 1330 (s), 1270 (s), 
1212 (s), 1131 (m), 1017 (m). ${ }^{1} \mathbf{H}$ NMR (400 MHz, $\left.\mathrm{CDCl}_{3}\right) \delta 8.04$ (s, 1H, ArH), 7.73 (s, 1H, $\left.\mathrm{ArH}\right)$, $7.53-7.47$ (m, 1H, ArH), 7.43 (m, 1H, ArH), 7.40 (dd, $J=8.2,1.2 \mathrm{~Hz}, 1 \mathrm{H}, \operatorname{Ar} H), 7.29$ (ddd, $J=$ 8.0, 7.1, 1.0 Hz, 1H, ArH), 6.12 (s, 1H, ArH), 4.03 (s, 3H, Me), 3.87 (s, 3H, Me), 3.20 (s, 3H, Me). ${ }^{13}$ C NMR $\left(101 \mathrm{MHz}, \mathrm{CDCl}_{3}\right) \delta 167.2,153.2,150.9,139.3,137.4,129.1,126.4,124.2,122.5$, $119.9,113.3,110.6,107.3,104.9,79.0,56.3,55.7$, 33.9. HR-ESI-MS $438.0197\left([\mathrm{M}+\mathrm{H}]^{+}\right.$, $\mathrm{C}_{18} \mathrm{H}_{17} \mathrm{INO}_{4}{ }^{+}$; calc. for 438.0197). The structure of the obtained regioisomer was assigned by NMR correlation to compound 25.

5,6-Dimethoxy-1-(2-1-methyl-1H-pyrrole)- $1 H$-1 $1 \lambda_{3}$-benzo[b]iodo-3(2H)-one (40a) and 5,6dimethoxy-1-(3-1-methyl-1H-pyrrole)- $1 H-1 \lambda_{3}$-benzo $[b]$ iodo-3(2H)-one (40b)<smiles>COc1cc2c(cc1OC)I(c1cccn1C)OC2=O</smiles>

$40 a$<smiles>COc1cc(I)c(-c2ccn(C)c2)c(OC)c1</smiles>

$40 \mathrm{~b}$

Following procedure B: starting from commercially available 1 -methyl- $1 H$-pyrrole 12 (17.8 $\mu 1,0.200 \mathrm{mmol})$ and 5,6-dimethoxy-3oxobenzo $[d][1,2]$ iodaoxol-1 $(3 H)$-yl acetate 95 (81.0 mg, $0.220 \mathrm{mmol}, 1.10$ equiv.), after 12 hours 5,6-dimethoxy-1-(2-1-methyl-1Hpyrrole)- $1 H-1 \lambda_{3}$-benzo[b]iodo-3(2H)-one 40a and 5,6-dimethoxy-1-(3-1-methyl-1H-pyrrole)- $1 H$-1 $\lambda_{3} \quad$-benzo[b]iodo-3(2H)-one $40 \mathrm{~b}$ were obtained in 1:2 mixture (77.0 mg, $0.199 \mathrm{mmol}$, overall yield $99 \%)$, as a yellow foam. Rf: 0.40 (DCM:MeOH 9:1). The two compounds were separated by slow flash column chromatography (EtOAc:MeOH 20:1). The structure of the obtained regioisomers were assigned by NMR correlation to compound 37.

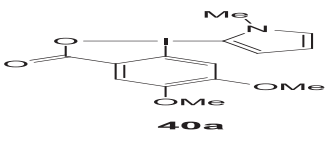

5,6-dimethoxy-1-(2-1-methyl-1H-pyrrole)- $\quad 1 H$-1 $\lambda_{3} \quad$-benzo[b]iodo$3(2 H)$-one $40 \mathrm{a}(26.0 \mathrm{mg}, 67.0 \mu \mathrm{mol}, 33 \%$ yield); yellow foam. Rf: 0.40 (EtOAc:MeOH 9:1). IR v 3104 (w), 2942 (w), 2848 (w), 1607 (s), 1562 (s), 1498 (s), 1392 (s), 1270 (s), 1212 (s), 1182 (m), 1019 (m). ${ }^{\mathbf{1}} \mathbf{H}$ NMR $\left(400 \mathrm{MHz}, \mathrm{CDCl}_{3}\right) \delta 7.88(\mathrm{~s}, 1 \mathrm{H}, \mathrm{Ar} H), 7.07(\mathrm{dd}, J=2.8,1.6 \mathrm{~Hz}, 1 \mathrm{H}$, $\operatorname{Ar} H), 6.92(\mathrm{dd}, J=3.9,1.6 \mathrm{~Hz}, 1 \mathrm{H}, \operatorname{Ar} H), 6.42(\mathrm{dd}, J=3.9,2.8 \mathrm{~Hz}, 1 \mathrm{H}$, $\operatorname{ArH}), 5.83$ (s, 1H, ArH), 3.95 (s, 3H, Me), 3.76 (s, 3H, Me), 3.57 (s, 3H, Me). ${ }^{13}$ C NMR $\left(101 \mathrm{MHz}, \mathrm{CDCl}_{3}\right) \delta 166.8,154.1,151.5,129.3,126.5,125.3,113.6,112.1,107.6$, 
106.2, 98.0, 56.6, 56.1, 37.4. HR-ESI-MS 388.0034 ([M+H $]^{+}, \mathrm{C}_{14} \mathrm{H}_{15} \mathrm{INO}_{4}{ }^{+}$; calc. for 388.0040). The structure of the obtained regioisomer was assigned by NMR correlation to compound 37.<smiles>COc1cc(I)c(-c2ccn(C)c2)c(OC)c1</smiles>

$40 \mathrm{~b}$

5,6-dimethoxy-1-(3-1-methyl-1H-pyrrole)- $\quad 1 H-1 \lambda_{3} \quad$-benzo[b]iodo3(2H)-one 40b (51.0 mg, $0.132 \mathrm{mmol}, 66 \%$ yield); yellow foam. Rf: 0.38 (EtOAc:MeOH 9:1). IR $v 3109$ (w), 2941 (w), 2850 (w), 1609 (m), 1562 (s), 1498 (s), 1392 (s), $1326(\mathrm{~m}), 1270$ (s), 1212 (s), 1182 (w), 1128 (w), 1019 (m). ${ }^{1} \mathbf{H}$ NMR (400 MHz, $\left.\mathrm{CDCl}_{3}\right) \delta 7.84(\mathrm{~s}, 1 \mathrm{H}, \mathrm{ArH}), 7.25$ (d, $J=1.9 \mathrm{~Hz}, 1 \mathrm{H}, \operatorname{Ar} H), 6.84(\mathrm{~s}, 1 \mathrm{H}, \operatorname{Ar} H), 6.54(\mathrm{~m}, 1 \mathrm{H}, \operatorname{Ar} H), 6.36$ (s, $1 \mathrm{H}, \mathrm{ArH}), 3.94(\mathrm{~s}, 3 \mathrm{H}, \mathrm{Me}), 3.85(\mathrm{~s}, 3 \mathrm{H}, \mathrm{Me}), 3.62(\mathrm{~s}, 3 \mathrm{H}, \mathrm{Me}) .{ }^{13} \mathbf{C}$ NMR $\left(101 \mathrm{MHz}, \mathrm{CDCl}_{3}\right) \delta 167.0,153.3,151.0,131.3,126.6,125.9,115.7,113.4,107.3,105.6,85.0$, 56.4, 56.0, 37.0. HR-ESI-MS 388.0035 $\left([\mathrm{M}+\mathrm{H}]^{+}, \mathrm{C}_{14} \mathrm{H}_{15} \mathrm{INO}_{4}{ }^{+}\right.$; calc. for 388.0040). The structure of the obtained regioisomer was assigned by NMR correlation to compound 37.

4-Fluoro-1-(2-1-methyl-1H-pyrrole)- $1 H-1 \lambda_{3}$-benzo[b]iodo-3(2H)-one (41a) and 4-Fluoro-1(3-1-methyl-1H-pyrrole)- $1 H$-1 $\lambda_{3}$-benzo[b]iodo-3(2H)-one (41b)<smiles>Cn1cccc1I1COC(=O)c2c(F)cccc21</smiles>

$41 a$<smiles>Cn1ccc(I2OC(=O)c3c(F)cccc32)c1</smiles>

$41 b$

Following procedure B: starting from commercially available 1-methyl- $1 H$-pyrrole 12 $(17.8 \mu \mathrm{l}, 0.200 \mathrm{mmol})$ and 4-fluoro-3-oxo- $1 \lambda_{3-}$ benzo[d][1,2]iodaoxol-1(3H)-yl acetate $96(71.3$ $\mathrm{mg}, 0.220 \mathrm{mmol}, 1.10$ equiv.), after 12 hours $4-$ Fluoro-1-(2-1-methyl-1H-pyrrole)- $1 H-1 \lambda_{3}-$ benzo[b]iodo-3(2H)-one 41a and -Fluoro-1-(3-1-methyl-1H-pyrrole)- $1 H$ - $1 \lambda_{3}$-benzo[b]iodo$3(2 \mathrm{H})$-one $41 \mathrm{~b}$ were obtained in 1:3 mixture (44.1 $\mathrm{mg}, 0.128 \mathrm{mmol}$, overall yield $64 \%$ ), as a yellow foam. Rf: 0.40 (DCM:MeOH 9:1). The two compounds were separated by slow flash column chromatography (EtOAc:MeOH 20:1). The structure of the obtained regioisomers were assigned by NMR correlation to compound 37. 


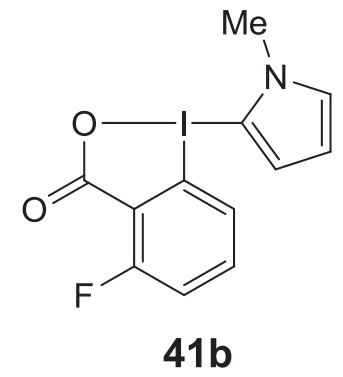

4-Fluoro-1-(2-1-methyl-1H-pyrrole)- $1 H$-1 $1 \lambda_{3}$-benzo[b]iodo-3(2H)-one 41b (11.1 mg, $32.0 \mu \mathrm{mol}, 16 \%$ yield); yellow foam. Rf: 0.36 (EtOAc:MeOH 9:1). IR $v 3105(\mathrm{w}), 2918(\mathrm{w}), 2851(\mathrm{w}), 1636(\mathrm{~s}), 1593(\mathrm{~m}), 1564(\mathrm{w}), 1515(\mathrm{w})$, 1449 (m), 1422 (w), 1325 (m), 1242 (m), 1112 (m). ${ }^{1}$ H NMR (400 MHz, $\left.\mathrm{CDCl}_{3}\right) \delta 7.45-7.28(\mathrm{~m}, 2 \mathrm{H}, \mathrm{Ar} H), 7.07(\mathrm{dd}, J=2.8,1.6 \mathrm{~Hz}, 1 \mathrm{H}, \mathrm{Ar} H), 6.91$ $(\mathrm{dd}, J=3.9,1.6 \mathrm{~Hz}, 1 \mathrm{H}, \operatorname{Ar} H), 6.48(\mathrm{dt}, J=7.9,1.0 \mathrm{~Hz}, 1 \mathrm{H}, \mathrm{Ar} H), 6.42$ (dd, $J=3.9,2.8 \mathrm{~Hz}, 1 \mathrm{H}, \mathrm{ArH}), 3.74(\mathrm{~s}, 3 \mathrm{H}, \mathrm{NMe}) .{ }^{13} \mathbf{C} \mathbf{N M R}\left(101 \mathrm{MHz}, \mathrm{CDCl}_{3}\right) \delta$ 152.6, 134.0, 133.9, 129.9, 125.6, 121.6, 120.7, 120.6, 120.3, 120.0, 112.3, 37.3. HR-ESI-MS $345.9730\left([\mathrm{M}+\mathrm{H}]^{+}\right.$, $\mathrm{C}_{12} \mathrm{H}_{10} \mathrm{FINO}_{2}{ }^{+}$; calc. for 345.9735). The structure of the obtained regioisomer was assigned by NMR correlation to compound 37.

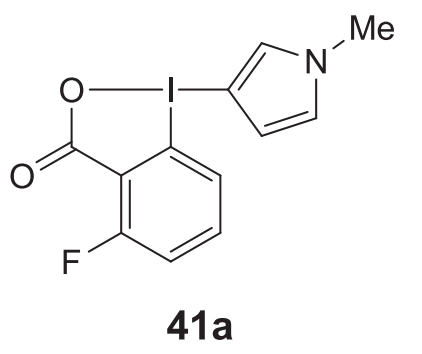

4-Fluoro-1-(3-1-methyl-1H-pyrrole)- $1 H$-1 $\lambda_{3}$-benzo[b]iodo-3(2H)-one $41 \mathrm{a}$ (33.0 mg, $96.0 \mu \mathrm{mol}, 48 \%$ yield); yellow foam. Rf: 0.38 (EtOAc:MeOH 9:1). IR v 2919 (m), 2851 (w), 1638 (s), 1612 (s), 1592 (m), 1452 (w), 1339 (w), 1311 (w), 1287 (m), 1233 (w). ${ }^{1}$ H NMR (400 $\left.\mathrm{MHz}, \mathrm{CDCl}_{3}\right) \delta 7.32(\mathrm{td}, J=8.1,4.6 \mathrm{~Hz}, 1 \mathrm{H}, \mathrm{ArH}), 7.27-7.22(\mathrm{~m}, 2 \mathrm{H}$, $\operatorname{Ar} H), 6.87-6.82(\mathrm{~m}, 2 \mathrm{H}, \operatorname{Ar} H), 6.50(\mathrm{dd}, J=2.9,1.7 \mathrm{~Hz}, 1 \mathrm{H}, \operatorname{Ar} H)$, $3.85(\mathrm{~s}, 3 \mathrm{H}, \mathrm{NMe}) .{ }^{13} \mathrm{C}$ NMR $\left(101 \mathrm{MHz}, \mathrm{CDCl}_{3}\right) \delta 164.6(\mathrm{~d}, J=266.7 \mathrm{~Hz}), 163.2,133.11(\mathrm{~d}, J=$ $8.6 \mathrm{~Hz}), 131.3,126.2,121.80(\mathrm{~d}, J=12.7 \mathrm{~Hz}), 121.36(\mathrm{~d}, J=3.8 \mathrm{~Hz}), 119.8,119.5(\mathrm{~d}, J=23.7$ $\mathrm{Hz}), 115.7,85.9$, 37.0. HR-ESI-MS 345.9731 ([M+H] $]^{+}, \mathrm{C}_{12} \mathrm{H}_{10} \mathrm{FINO}_{2}{ }^{+}$; calc. for 345.9735). The structure of the obtained regioisomer was assigned by NMR correlation to compound 37.

5-Nitro-1-(2-1-Methyl-1 $H$-pyrrole)-1 $H$-1 $\lambda_{3}$-benzo $[d][1,2]$ iodoxol-3-one (42a) and 5-Nitro-1(3-1-methyl-1H-pyrrole)-1H-1 $\lambda_{3}$-benzo $[d][1,2]$ iodoxol-3-one (42b)

Following procedure B: starting from commercially available 1 -methyl- $1 H$-pyrrole $12(17.8 \mu \mathrm{l}, 0.200 \mathrm{mmol})$ and 1-acetoxy-5nitro-1,2-benziodoxol-3(1H)-one 97 (77.0 mg, $0.220 \mathrm{mmol}, 1.10$ equiv.), after 12 hours 5nitro-1-(2-1-methyl-1H-pyrrole)- $1 H-1 \lambda_{3}-$ benzo $[d][1,2]$ iodoxol-3-one (42a) and 5-nitro- 
1-(3-1-methyl-1H-pyrrole)-1H-1 $\lambda_{3}$-benzo[d][1,2]iodoxol-3-one (42b) were obtained in 4:1 mixture (69.5 mg, $0.187 \mathrm{mmol}$, overall yield 93\%), as a yellow foam. Rf: 0.50 (DCM:MeOH 9:1). The two compounds were separated by slow flash column chromatography (EtOAc:MeOH 20:1). The structure of the obtained regioisomers were assigned by NMR correlation to compound 37.<smiles>Cn1cccc1I1COC(=O)c2cc([N+](=O)[O-])ccc21</smiles>
5-nitro-1-(2-1-Methyl-1 $H$-pyrrole)- $1 H$-1 $\lambda_{3}$-benzo[ $\left.d\right][1,2]$ iodoxol-3-one 42a (54.9 mg, $0.148 \mathrm{mmol}, 74 \%$ yield); yellow foam. Rf: 0.50 (EtOAc:MeOH 9:1). NB: the reagent is unstable in acidic deuterated solvents and it decompose in short time, we recommend the immediate use after the synthesis. The proton NMR presents about 6\% of the open protonated 42a acidic form. IR $v 3103$ (w), 2935 (w), 2925 (w), 2856 (w), 1785 (w), 1716 (m), 1617 (m), 1530 (s), 1459 (w), 1346 (s), 1288 (m), 1250 (m). ${ }^{1} \mathbf{H}$ NMR (400 MHz, CDCl 3 ) $\delta$ $9.13(\mathrm{~d}, J=2.6 \mathrm{~Hz}, 1 \mathrm{H}, \mathrm{Ar} H), 8.27$ (dd, $J=8.8,2.5 \mathrm{~Hz}, 1 \mathrm{H}, \mathrm{Ar} H), 7.13(\mathrm{dd}, J=2.8,1.5 \mathrm{~Hz}, 1 \mathrm{H}$, $\operatorname{Ar} H), 6.97(\mathrm{dd}, J=4.0,1.6 \mathrm{~Hz}, 1 \mathrm{H}, \operatorname{Ar} H), 6.82(\mathrm{~d}, J=8.9 \mathrm{~Hz}, 1 \mathrm{H}, \operatorname{Ar} H), 6.47(\mathrm{~d}, J=1.1 \mathrm{~Hz}, 1 \mathrm{H}$, $\mathrm{ArH}), 3.80(\mathrm{~s}, 3 \mathrm{H}, \mathrm{NMe}) .{ }^{13} \mathbf{C}$ NMR $\left(101 \mathrm{MHz}, \mathrm{CDCl}_{3}\right) \delta 164.9,150.6,135.6,130.4,127.8,127.0$, 126.6, 126.0, 124.8, 112.7, 96.6, 37.5. HR-ESI-MS $372.9690\left([\mathrm{M}+\mathrm{H}]^{+}, \mathrm{C}_{12} \mathrm{H}_{10} \mathrm{IN}_{2} \mathrm{O}_{4}{ }^{++}\right.$; calc. for 372.9680). The structure of the obtained regioisomer was assigned by NMR correlation to compound 37.

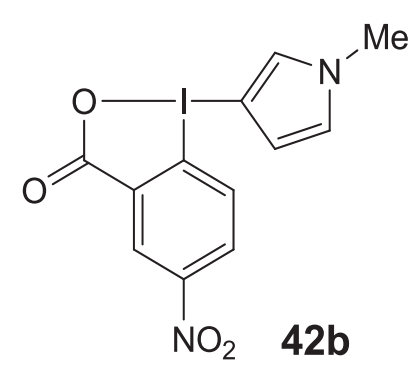

5-nitro-1-(3-1-Methyl-1 $H$-pyrrole)-1 $H$-1 $1 \lambda_{3}$-benzo[d][1,2]iodoxol-3-one 42b (14.6 mg, $0.039 \mathrm{mmol}, 19 \%$ yield); yellow foam. Rf: 0.46 (EtOAc: $\mathrm{MeOH} 9: 1$ ). NB: the reagent is unstable in acidic deuterated solvents and it decompose in short time, we recommend the immediate use after the synthesis. The proton and carbon NMRs present about 8\% of the open protonated acidic form. IR $v 3092$ (w), 2957 (w), 2928 (w), 1716 (m), 1623 (m), 1529 (s), 1346 (s), 1303 (w), 1109 (w), 1076 (w). ${ }^{1}$ H NMR (400 MHz, $\left.\mathrm{CDCl}_{3}\right) \delta 9.18(\mathrm{~d}, J=2.6 \mathrm{~Hz}, 1 \mathrm{H}, \mathrm{Ar} H), 8.24(\mathrm{dd}, J=8.9,2.7 \mathrm{~Hz}, 1 \mathrm{H}, \mathrm{Ar} H), 7.23(\mathrm{t}, J=1.9 \mathrm{~Hz}$, $1 \mathrm{H}, \operatorname{Ar} H), 7.20(\mathrm{~d}, J=8.9 \mathrm{~Hz}, 1 \mathrm{H}, \operatorname{Ar} H), 6.90(\mathrm{~m}, 1 \mathrm{H}, \operatorname{Ar} H), 6.56(\mathrm{dd}, J=2.9,1.7 \mathrm{~Hz}, 1 \mathrm{H}, \operatorname{Ar} H)$, 3.89 (s, 3H, NMe). ${ }^{13} \mathbf{C}$ NMR $\left(101 \mathrm{MHz}, \mathrm{CDCl}_{3}\right) \delta 194.4,150.5,135.6,131.3,127.1,126.8,126.7$, 126.6, 122.3, 115.8, 84.2, 37.2. HR-ESI-MS $372.9691\left([\mathrm{M}+\mathrm{H}]^{+}, \mathrm{C}_{12} \mathrm{H}_{10} \mathrm{IN}_{2} \mathrm{O}_{4}{ }^{++}\right.$; calc. for 
372.9680). The structure of the obtained regioisomer was assigned by NMR correlation to compound 37.<smiles>Cn1cc(I2COC(=O)c3ccccc32)c2cccnc21</smiles>

43 $26 \%$ yield<smiles>O=C1OI(c2cccs2)c2ccccc21</smiles>

45

$31 \%$ yield<smiles>Cn1c2ccccc2c2cc(I3C(=O)c4ccccc43)ccc21</smiles>

44

$33 \%$ yield<smiles>Cc1cc(I2COC(=O)c3ccccc32)c(C)o1</smiles>

46

$14 \%$ yield

Figure S7: Scope of Heterocyclic-BX reagents (6)

\section{1-(3-1-Methyl-1H-pyrrolo[2,3-b]pyridine)-1H-1 $\lambda_{3}$-benzo[b]iodo-3(2H)-one (43)}<smiles>Cn1cc(I2COC(=O)c3ccccc32)c2cccnc21</smiles>

43

Following procedure $\mathbf{A}$ : starting from commercially available 1-methyl$1 H$-pyrrolo[2,3-b]pyridine (132 mg, $1.00 \mathrm{mmol})$, after 16 hours $1-(3-1-$ methyl-1H-pyrrolo[2,3- $b]$ pyridine)- $1 H$-1 $1 \lambda_{3}$-benzo[ $\left.b\right]$ iodo-3(2H)-one 43 (114 mg, $0.301 \mathrm{mmol}, 30 \%$ yield) was obtained as a brown amorphous solid. Rf: 0.2 (DCM:MeOH 9:1). IR v 2925 (w), 2852 (w), 1719 (s), $1599(\mathrm{~m}), 1585$ (m), 1468 (m), 1408 (w), 1348 (w), 1289 (m), 1262 (s), 1136 (m), 1103 (w), 1042 (w), 1017 (m), 976 (w). ${ }^{1} \mathbf{H}$ NMR (400 MHz, $\left.\mathrm{CD}_{2} \mathrm{Cl}_{2}\right) \delta 8.37$ (dd, $J=$ 4.7, 1.6 Hz, 1H, ArH), 8.06 (dd, $J=7.9,1.2 \mathrm{~Hz}, 1 \mathrm{H}, \operatorname{Ar} H), 7.96$ (dd, $J=7.9,1.7 \mathrm{~Hz}, 1 \mathrm{H}, \operatorname{Ar} H$ ), $7.92(\mathrm{dd}, J=7.9,1.7 \mathrm{~Hz}, 1 \mathrm{H}, \operatorname{Ar} H), 7.46$ (td, $J=7.7,1.2 \mathrm{~Hz}, 1 \mathrm{H}, \operatorname{Ar} H), 7.25-7.19$ (m, 2H, ArH), $7.14(\mathrm{dd}, J=7.9,4.7 \mathrm{~Hz}, 1 \mathrm{H}, \mathrm{ArH}), 3.86\left(\mathrm{~s}, 3 \mathrm{H}, \mathrm{CH}_{3} \mathrm{~N}\right) .{ }^{13} \mathbf{C}$ NMR $\left(101 \mathrm{MHz}, \mathrm{CD}_{2} \mathrm{Cl}_{2}\right) \delta 168.6$, 144.4, 142.3, 134.3, 133.8, 132.1, 128.7, 127.0, 126.3, 118.8, 116.5, 103.2, 94.9, 31.7 (one Carbon 
signal not resolved). HR-ESI-MS $378.9945\left([\mathrm{M}+\mathrm{H}]^{+}, \mathrm{C}_{15} \mathrm{H}_{12} \mathrm{IN}_{2} \mathrm{O}_{2}{ }^{+}\right.$; calc. for 378.9938). The structure of the obtained regioisomer was assigned by NMR correlation to compound $\mathbf{9 b}$.

\section{1-(3-9-Methyl-9H-carbazole)-1 $H$-1 $\lambda_{3}$-benzo $[b]$ iodo-3(2H)-one (44)}<smiles>Cn1c2ccccc2c2cc(I3OC(=O)c4ccccc43)ccc21</smiles>

44

Following procedure A: starting from commercially available 9methyl-9H-carbazole (181 mg, $1.00 \mathrm{mmol})$, after 16 hours 1-(3-9methyl-9H-carbazole)- $1 H$-1 $\lambda_{3}$-benzo[b]iodo-3(2H)-one 9m (110 $\mathrm{mg}, 0.257 \mathrm{mmol}, 33 \%$ yield) was obtained as a grey amorphous solid. Rf: 0.2 (DCM:MeOH 9:1). IR v 3082 (w), 2974 (w), 2924 (w), $2816(\mathrm{w}), 1652$ (s), $1588(\mathrm{w}), 1570$ (w), 1456 (w), 1440 (m), 1295 (m), 1245 (w), 1139 (w), 1017 (w), 982 (m), 831 (w). ${ }^{1} \mathbf{H}$ NMR (400 MHz, CDCl 3 ) $\delta 8.67$ (d, J=1.6 Hz, 1H, ArH), 8.47 (dd, $J=7.5,1.7 \mathrm{~Hz}, 1 \mathrm{H}, \operatorname{Ar} H), 8.14(\mathrm{~d}, J=7.9 \mathrm{~Hz}, 1 \mathrm{H}, \mathrm{Ar} H), 7.96(\mathrm{dd}, J=8.5,1.6 \mathrm{~Hz}, 1 \mathrm{H}, \operatorname{Ar} H)$, 7.63 (ddd, $J=8.4,7.1,1.2 \mathrm{~Hz}, 1 \mathrm{H}, \operatorname{Ar} H), 7.59$ (d, $J=8.5 \mathrm{~Hz}, 1 \mathrm{H}, \operatorname{Ar} H), 7.57-7.52(\mathrm{~m}, 2 \mathrm{H}, \operatorname{Ar} H)$, $7.37(\mathrm{td}, J=7.5,1.2 \mathrm{~Hz}, 1 \mathrm{H}, \operatorname{Ar} H), 7.30(\mathrm{ddd}, J=8.5,7.1,1.7 \mathrm{~Hz}, 1 \mathrm{H}, \operatorname{Ar} H), 6.69(\mathrm{dd}, J=8.5,0.9$ $\mathrm{Hz}, 1 \mathrm{H}, \mathrm{ArH}), 3.98\left(\mathrm{~s}, 3 \mathrm{H}, \mathrm{NCH}_{3}\right) .{ }^{13} \mathbf{C} \mathbf{N M R}\left(101 \mathrm{MHz}, \mathrm{CDCl}_{3}\right) \delta 166.5,142.4,141.4,133.4$, $133.3,132.7,130.6,130.0,127.7,125.8,125.7,121.4,120.8,120.7,116.3,112.0,109.3,101.8$, 53.4, 29.5. HR-ESI-MS $428.0147\left([\mathrm{M}+\mathrm{H}]^{+}, \mathrm{C}_{20} \mathrm{H}_{15} \mathrm{INO}_{2}{ }^{+}\right.$; calc. for 428.0142).

\section{1-(2-1H-Thiophene)-1H-1 $\lambda_{3}$-benzo $[b]$ iodo-3(2H)-one (45)}

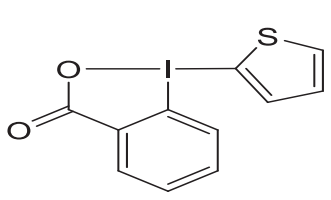

45

Following procedure A: starting from commercially available thiophene $(80.0 \mu \mathrm{L}, 1.00 \mathrm{mmol})$ and using $\mathrm{Sc}(\mathrm{OTf})_{3}$ as the Lewis Acid $(20 \mathrm{~mol} \%)$, after 16 hours 1 -(2-1H-thiophene)- $1 H-1 \lambda_{3}$-benzo[b]iodo-3(2H)-one (45) (102 $\mathrm{mg}, 0.309 \mathrm{mmol}, 31 \%$ yield) was obtained as a light yellow amorphous solid. NB: the reagent is unstable in protic deuterated solvents and it decompose in short time, we recommend the immediate use after the synthesis. The proton NMR presents about 7\% of the open protonated form. Rf: 0.4 (DCM:MeOH 9:1). IR v 3080 (w), 2958 (w), 2925 (m), 2853 (w), 1716 (w), 1622 (s), 1603 (s), 1558 (m), 1438 (w), 1354 (w), 1341 (w), 1299 (w), 1223 (w), 1006 (w), 951 (w), 834 (w), 830 (w). ${ }^{1}$ H NMR (400 MHz, $\left.\mathrm{CD}_{3} \mathrm{OD}\right) \delta 8.28(\mathrm{dd}, \mathrm{J}=7.5,1.7 \mathrm{~Hz}, 1 \mathrm{H}, \mathrm{ArH}), 8.05(\mathrm{dd}, \mathrm{J}=5.2,1.2 \mathrm{~Hz}, 1 \mathrm{H}, \operatorname{ArH}), 7.98(\mathrm{dd}, \mathrm{J}=$ 
3.7, $1.2 \mathrm{~Hz}, 1 \mathrm{H}, \operatorname{Ar} H), 7.70(\mathrm{td}, \mathrm{J}=7.4,0.9 \mathrm{~Hz}, 1 \mathrm{H}, \operatorname{Ar} H), 7.61$ (ddd, J = 8.7, 7.2, $1.7 \mathrm{~Hz}, 1 \mathrm{H}$, $\operatorname{Ar} H), 7.37(\mathrm{dd}, \mathrm{J}=5.3,3.6 \mathrm{~Hz}, 1 \mathrm{H}, \operatorname{Ar} H), 6.92(\mathrm{dd}, \mathrm{J}=8.3,0.9 \mathrm{~Hz}, 1 \mathrm{H}, \operatorname{Ar} H) .{ }^{13} \mathbf{C}$ NMR $(101$ $\left.\mathrm{MHz}, \mathrm{CDCl}_{3}\right) \delta 166.6,141.5,137.1,134.1,132.7,131.0,130.4,125.2,117.8,104.2$ (one aromatic Carbon signal not resolved). HR-ESI-MS $330.9291\left([\mathrm{M}+\mathrm{H}]^{+}, \mathrm{C}_{11} \mathrm{H}_{8} \mathrm{IO}_{2} \mathrm{~S}^{+}\right.$; calc. for 330.9284).

\section{1-(3-1H-2,5-dimethylfuran)-1H-1 $\lambda_{3}$-benzo[b]iodo-3(2H)-one (46)}<smiles>Cc1cc(I2OC(=O)c3ccccc32)c(C)o1</smiles>

46

Following procedure A: starting from commercially available 2,5dimethylfuran $(107 \mu \mathrm{L}, 1.00 \mathrm{mmol})$ and using $\operatorname{In}(\mathrm{OTf})_{3}$ as the Lewis Acid (20 mol\%), after 24 hours 1- (3-1H-2,5-dimethylfuran)-1H-1 $\lambda_{3}$ benzo[b]iodo-3(2H)-one (9t) (47.0 mg, $0.137 \mathrm{mmol}, 14 \%$ yield) was obtained as a brown resin. Rf: 0.3 (DCM:MeOH 9:1). IR v $3430(w)$, $3111(\mathrm{w}), 3065(\mathrm{w}), 2923(\mathrm{w}), 2854(\mathrm{w}), 1607$ (s), $1559(\mathrm{~m}), 1438(\mathrm{~m})$, 1348 (m), 1298 (w), 1229 (w), 1128 (w), 1039 (w), 1007 (w), 926 (w), 831 (m). ${ }^{1}$ H NMR (400 $\left.\mathrm{MHz}_{\mathrm{CDCl}}\right) \delta 8.28(\mathrm{dd}, \mathrm{J}=7.4,1.8 \mathrm{~Hz}, 1 \mathrm{H}, \mathrm{ArH}), 7.50(\mathrm{t}, \mathrm{J}=7.3 \mathrm{~Hz}, 1 \mathrm{H}, \operatorname{ArH}), 7.43(\mathrm{td}, \mathrm{J}=7.7$, 7.3, $1.8 \mathrm{~Hz}, 1 \mathrm{H}, \operatorname{Ar} H), 7.00(\mathrm{~d}, \mathrm{~J}=8.1 \mathrm{~Hz}, 1 \mathrm{H}, \operatorname{ArH}), 6.21$ (s, 1H, ArH), 2.42 (s, 3H, FuraneCH $)_{3}$, 2.31 (s, 3H, Furane $\left.\mathrm{CH}_{3}\right) .{ }^{13} \mathbf{C}$ NMR $\left(101 \mathrm{MHz}, \mathrm{CDCl}_{3}\right) \delta 166.9,158.9,154.2,133.5,133.1,132.4$, 130.4, 125.4, 115.0, 110.4, 88.0, 13.4, 13.2. HR-ESI-MS $342.9827\left([\mathrm{M}+\mathrm{H}]^{+}, \mathrm{C}_{13} \mathrm{H}_{12} \mathrm{IO}_{3}{ }^{+}\right.$; calc. for 342.9826).

\subsection{Preparation of Deuterated IndoleBX (49).}<smiles>Cn1ccc2ccccc21</smiles>

14

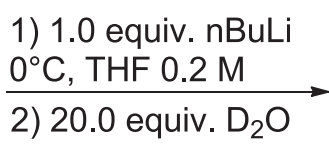

2) 20.0 equiv. $\mathrm{D}_{2} \mathrm{O}$<smiles>[2H]c1cc2ccccc2n1C</smiles>

48<smiles>[2H]c1c(I)c2ccccc2n1C</smiles>

49

Following a reported procedure, ${ }^{[19]}$ a flame dried flask is charged with freshly distilled 1-methyl$1 \mathrm{H}$-indole $14(0.374 \mathrm{ml}, 3.00 \mathrm{mmol})$ and then flushed with argon. Anhydrous THF $(9 \mathrm{~mL}, 0.3 \mathrm{M})$ is added, and the reaction is allowed to stir until all the 1-methylindole is dissolved. The solution is cooled to $0{ }^{\circ} \mathrm{C}$, and $\mathrm{nBuLi} 2.5 \mathrm{M}(1.80 \mathrm{~mL}, 4.50 \mathrm{mmol}, 1.5$ equiv. $)$ is added dropwise. The resulting solution is allowed to warm to ambient temperature, and allowed to stir for an additional 20 minutes. Then, $\mathrm{D}_{2} \mathrm{O}(1.20 \mathrm{~mL}, 60.0 \mathrm{mmol}, 20.0$ equiv. $)$ is added dropwise. After the solution is fully quenched with $\mathrm{D}_{2} \mathrm{O}$, it is extracted with hexane $(5 \times 3 \mathrm{~mL})$. Then the organic phase is dried 
over $\mathrm{Na}_{2} \mathrm{SO}_{4}$ and the solvent is removed in vacuo. The final product 48 was purified by distillation from molecular sieves. The product was $88 \%$ enriched with deuterium in the 2-position, as determined by ${ }^{1} \mathrm{H}$ NMR.

Following general procedure A, 1-(2- $D$-1-methylindole)- $1 H$ - $1 \lambda_{3}$-benzo $[b]$ iodo-3(2H)-one 49 (215 $\mathrm{mg}, 0.569 \mathrm{mmol}, 56.9 \%$ yield) is obtained as a slightly brown foam. The product was $\mathbf{8 8} \%$ enriched with deuterium in the 2-position, as determined by ${ }^{1} \mathrm{H}$ NMR. Rf: 0.28 (DCM:MeOH 9:1). IR v 3057 (w), 2945 (w), 2326 (w), 1601 (s), 1555 (m), 1474 (m), 1415 (m), 1359 (m), 1277 (m), 1262 (m), 1157 (w), 1032 (m), 899 (m), 832 (m). ${ }^{1} \mathbf{H}$ NMR (400 MHz, CDCl 3 :AcOH 10:1) $\delta$ $8.22(\mathrm{dd}, J=7.5,1.7 \mathrm{~Hz}, 1 \mathrm{H}, \mathrm{Ar} H), 8.02(\mathrm{~s}, 0.12 \mathrm{H}, \mathrm{CH}+\mathrm{C} D), 7.48(\mathrm{~d}, J=8.3 \mathrm{~Hz}, 1 \mathrm{H}, \mathrm{ArH}), 7.40$ - 7.33 (m, 2H, ArH), 7.32 (d, $J=7.9 \mathrm{~Hz}, 1 \mathrm{H}, \operatorname{Ar} H), 7.22$ (t, $J=7.5 \mathrm{~Hz}, 1 \mathrm{H}, \operatorname{Ar} H$ ), 7.18 (ddd, $J=$ 8.6, 5.8, $2.3 \mathrm{~Hz}, 1 \mathrm{H}, \mathrm{ArH}), 6.76(\mathrm{~d}, J=8.3 \mathrm{~Hz}, 1 \mathrm{H}, \mathrm{ArH}), 4.00(\mathrm{~s}, 3 \mathrm{H}, \mathrm{NCH}) .{ }^{13} \mathbf{C}$ NMR $(101$ $\left.\mathrm{MHz}, \mathrm{CDCl}_{3}\right) \delta 167.3,139.3(\mathrm{~m}, C-D), 137.4,133.2,133.0,132.1,130.2,129.1,125.5,123.9$, 122.3, 119.5, 115.8, 110.7, 77.3, 33.8. HR-ESI-MS $378.9989\left([\mathrm{M}+\mathrm{H}]^{+}, \mathrm{C}_{16} \mathrm{H}_{13} \mathrm{INO}_{2}{ }^{+}\right.$; calc. for 378.9987).

\subsection{Preparation of $\beta$-Phenyliodonioindole Tetrafluoroborate (53).}<smiles>c1ccc2[nH]ccc2c1</smiles>

1) 5.0 equiv. $\mathrm{KOH}$ $\underset{\mathrm{MeOH} 1 \mathrm{M}, 0^{\circ} \mathrm{C}}{\stackrel{\mathrm{M}}{1.0} \text { equiv. PIDA }}$ $0{ }^{\circ} \mathrm{C}$

116

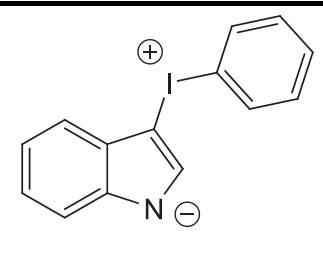

Betaine I
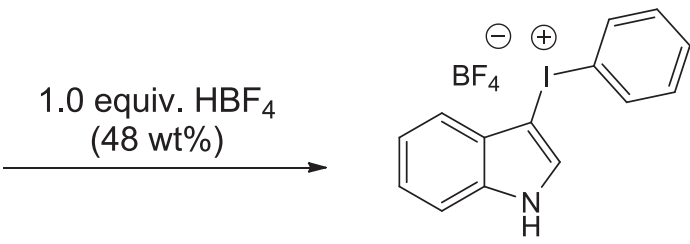

53

Following a reported procedure, ${ }^{[20]}$ to a stirred solution of fine crushed $\mathrm{KOH}(5.61 \mathrm{~g}, 100 \mathrm{mmol}$, 5.00 equiv.) in $\mathrm{MeOH}(20.0 \mathrm{~mL}, 1.0 \mathrm{M}), 1 H$-indole 116 (2.34 g, $20.0 \mathrm{mmol}, 1.00$ equiv.) was added in portions at $0{ }^{\circ} \mathrm{C}$. The resulting mixture was left stirring at $0{ }^{\circ} \mathrm{C}$ until complete dissolution of the $1 H$-indole (1.5 h). Then PIDA (6.44 g, $20.0 \mathrm{mmol}, 1.00$ equiv.) was added portionwise and the reaction mixture left stirring at $0{ }^{\circ} \mathrm{C}$ for $1.5 \mathrm{~h}$. Betaine $\mathbf{I}$ intermediate (dark yellow green solid in suspension) was then removed by filtration over a glass-synthered funnel, washed with cold $\mathrm{MeOH}$ and $\mathrm{CHCl}_{3}$ and air dried in the dark at $0{ }^{\circ} \mathrm{C}$. Betaine $\mathbf{I}$ intermediate $(2.20 \mathrm{~g}, 6.89 \mathrm{mmol}, 35 \%$ yield $)$ was obtained as a dark yellow green amorphous solid. 
Caution: Betaine I is a highly unstable intermediate, it is reported to detonate at room temperature; do NOT grind it, it may explode. The Betaine I intermediate decomposes at $-20^{\circ} \mathrm{C}$, it is recommended to be used immediately after its preparation.

$\mathrm{HBF}_{4}\left(450 \mu \mathrm{L}, 6.89 \mathrm{mmol}, 1.00\right.$ equiv., 48 wt.\% solution in $\left.\mathrm{H}_{2} \mathrm{O}\right)$ was added to EtOH $(10 \mathrm{~mL})$ and the resulting solution cooled at $-15^{\circ} \mathrm{C}$; then Betaine I intermediate $(2.20 \mathrm{~g}, 6.89 \mathrm{mmol}, 1.00$ equiv.) was added portionwise under vigorous stirring at $-15^{\circ} \mathrm{C}$. After all of Betaine $\mathbf{I}$ had been added, the dark brown resulting reaction mixture was diluted with $\mathrm{Et}_{2} \mathrm{O}(50 \mathrm{~mL})$ and stirred for $1.5 \mathrm{~h}$ at -15 ${ }^{\circ} \mathrm{C}$. Then stirring was stopped and the reaction left at $-15^{\circ} \mathrm{C}$ for $30 \mathrm{~min}$. The resulting precipitate was then removed by filtration over a glass-synthered funnel and dried at $0{ }^{\circ} \mathrm{C}$ to give $\beta$ Phenyliodonioindole Tetrafluoroborate 53 (2.10 g, $5.16 \mathrm{mmol}, 75 \%$ yield $)$ as a yellowish green amorphous solid.

Caution: $\beta$-Phenyliodonioindole Tetrafluoroborate 53 is an unstable salt and it was immediately used after its preparation.

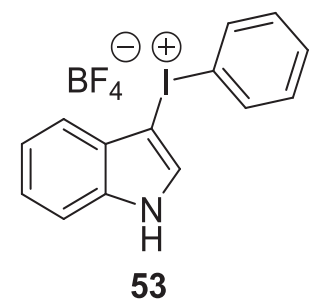

IR $v 3375$ (s), 3132 (w), 1561 (m), 1491 (m), 1472 (s), 1411 (s), 1340 (m), 1328 (m), 1279 (s), 1244 (s). ${ }^{\mathbf{1} H}$ NMR (400 MHz, DMSO-d $) \delta 12.32$ (brs, $1 \mathrm{H}, \mathrm{NH}), 8.40(\mathrm{~d}, J=2.7 \mathrm{~Hz}, 1 \mathrm{H}, \mathrm{ArH}), 8.14-8.12$ (m, 2H, ArH), 7.74 (m, $1 \mathrm{H}, \mathrm{ArH}), 7.58-7.55(\mathrm{~m}, 2 \mathrm{H}), 7.47-7.43(\mathrm{~m}, 2 \mathrm{H}), 7.35-7.16(\mathrm{~m}, 2 \mathrm{H})$. (presence of $\mathrm{Et}_{2} \mathrm{O}$ residual solvent as the NMR analysis was performed on the slightly wet compound to prevent decomposition). ${ }^{13} \mathbf{C}$ NMR (101 MHz, DMSO- $\left.d_{6}\right) \delta 135.8,135.1$, 134.0, 131.5, 127.1, 123.6, 121.9, 118.8, 117.3, 113.0, 78.0. (one aromatic Carbon signal not resolved). HR-ESI-MS $319.9932\left(\left[\mathrm{M}^{+}\right], \mathrm{C}_{14} \mathrm{H}_{11} \mathrm{IN}\right.$; calc. for 319.9931). 


\section{Rh-Catalyzed C-H Indolization of Arenes via C-H activation.}

All commercially available chemicals were purchased from the suppliers quoted in Paragraph 1.0 of Supplementary Informations: these chemicals were purified through a short plug of celite prior to their use in catalysis. The synthesis of non commercial available compounds is presented below. The synthesis of the starting materials $\mathbf{1 2 1}, \mathbf{1 2 3}, \mathbf{1 2 7}$ the optimization process of compound $\mathbf{5 2}$ and products 52, 54-75 had been already described before. ${ }^{[1]}$ The procedures here reported are taken from the cited publication to facilitate reproduction of the results by having all the data in the same file.

\subsection{Synthesis of Starting Materials.}

Methyl 4-(pyridin-2-yl)benzoate (44)
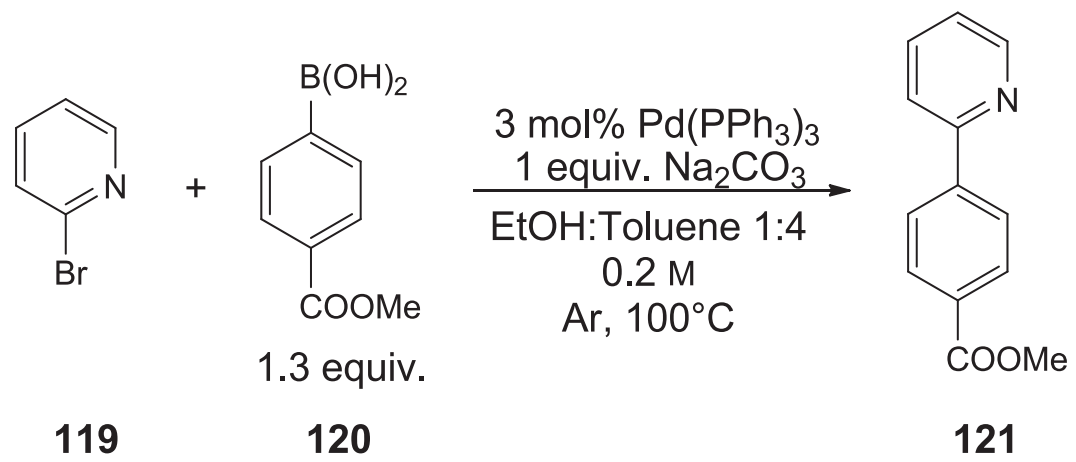

Following a reported procedure, ${ }^{[21]}$ to a solution of commercially available 2-bromopyridine 119 $(100 \mu \mathrm{L}, 1.00 \mathrm{mmol})$ in a mixture of $4 / 1$ toluene/EtOH $(5 \mathrm{~mL}, 0.2 \mathrm{M})$ was added $\mathrm{Na}_{2} \mathrm{CO}_{3}(106 \mathrm{mg}$, 1.00 mmol, 1.00 equiv.) followed by $\mathrm{Pd}\left(\mathrm{PPh}_{3}\right)_{4} \quad(34.7 \mathrm{mg}, 30.0 \mu \mathrm{mol}, 3 \mathrm{~mol} \%)$ and (4(methoxycarbonyl)phenyl)boronic acid 120 (234 mg, $1.30 \mathrm{mmol}, 1.30$ equiv.) under argon atmosphere in a $50 \mathrm{~mL}$ two-necked flask. The reaction mixture was refluxed for $12 \mathrm{~h}$, and then cooled to room temperature. To the reaction mixture was added sat. aqueous $\mathrm{NH}_{4} \mathrm{Cl}(15 \mathrm{~mL})$, then the mixture was extracted by EtOAc $(3 \times 5 \mathrm{ml})$. The combined organic extracts were dried over $\mathrm{MgSO}_{4}$, filtered and and concentrated in vacuo. The resulting crude product was purified by flash chromatography (Pentane:EtOAc 4:1) to afford methyl 4-(pyridin-2-yl)benzoate 121 (181 mg, $0.849 \mathrm{mmol}, 85 \%$ yield) as a white solid. IR $\vee 2944(\mathrm{w}), 2848(\mathrm{w}), 1708(\mathrm{~s}), 1606(\mathrm{w}), 1586(\mathrm{~m})$, 
1466 (w), 1435 (m), 1405 (w), 1319 (w), 1274 (s), 1194 (m), 1183 (m), $1153(\mathrm{w}), 1111(\mathrm{~s}), 1014$ (m), 965 (m), 868 (w), 830 (w), 797 (w), 754 (vs), 699 (m). ${ }^{1} \mathbf{H}$ NMR (400 MHz, CDCl $) \delta 8.64$ $(\mathrm{d}, J=4.7 \mathrm{~Hz}, 1 \mathrm{H}, \mathrm{Ar} H), 8.06$ (d, $J=8.4 \mathrm{~Hz}, 2 \mathrm{H}, \mathrm{Ar} H), 7.98$ (d, $J=8.3 \mathrm{~Hz}, 2 \mathrm{H}, \operatorname{Ar} H), 7.73-7.63$ $(\mathrm{m}, 2 \mathrm{H}, \operatorname{Ar} H), 7.19(\mathrm{q}, J=4.6 \mathrm{~Hz}, 1 \mathrm{H}, \operatorname{Ar} H), 3.85(\mathrm{~s}, 3 \mathrm{H} \mathrm{COOMe}) .{ }^{13} \mathbf{C} \mathbf{N M R}\left(101 \mathrm{MHz}, \mathrm{CDCl}_{3}\right)$ $\delta 166.8,156.1,149.8,143.4,136.8,130.3,130.0,126.7,122.8,120.9,52.1$. NMR values are in accordance with the data reported in literature. ${ }^{[20]}$

\section{1-(Pyrimidin-2-yl)-1H-indole (123)}<smiles>Clc1ncccn1</smiles>

122<smiles>c1ccc2[nH]ccc2c1</smiles>

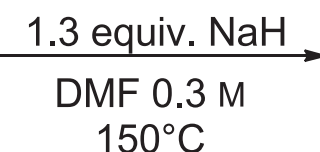

116

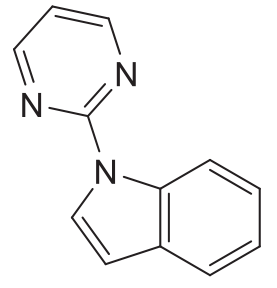

123

Following a reported procedure, ${ }^{[22]}$ commercially available $1 H$-indole 116 (586 mg, $\left.5.00 \mathrm{mmol}\right)$ was dissolved in $\mathrm{N}, \mathrm{N}$-dimethylformamide $(15.0 \mathrm{~mL}, 0.3 \mathrm{M})$ and sodium hydride $(60 \%$ suspension in mineral oil, $300 \mathrm{mg}, 7.50 \mathrm{mmol}, 1.50$ equiv.) was added at r.t. and the reaction mixture was stirred for one hour. Upon seizing of gas release, commercially available 2-chloropyrimidine 122 (573 mg, $5.00 \mathrm{mmol}, 1.00$ equiv.) was added portionwise. The reaction was heated up to $150{ }^{\circ} \mathrm{C}$ and stirred overnight. After 10 hours the reaction was allowed cooling to r.t. and was then quenched with water $(20 \mathrm{~mL})$. The majority of the solvent was removed under reduced pressure, then the crude was diluted with $\mathrm{Et}_{2} \mathrm{O}(25 \mathrm{~mL})$, the organic layer washed with brine $(3 \times 10 \mathrm{~mL})$, dried over $\mathrm{MgSO}_{4}$, filtered and concentrated under reduced pressure. Flash column chromatography (Pentane:EtOAc 4:1) afforded 1-(pyrimidin-2-yl)-1H-indole 123 (926 mg, 4.74 mmol, 95\% yield) as a light brown oil. IR v 3138 (w), 3108 (w), 1575 (s), 1525 (m), 1456 (s), 1309 (m), 1204 (s), 1080 (m), 970 (s), 776 (m), 750 (w), 731 (w). ${ }^{1} \mathbf{H}$ NMR (400 MHz, $\left.\mathrm{CDCl}_{3}\right) \delta 8.94$ (d, $J=8.4 \mathrm{~Hz}$, 1H, $\operatorname{Ar} H), 8.75(\mathrm{~d}, J=4.8 \mathrm{~Hz}, 2 \mathrm{H}, \operatorname{Ar} H), 8.40(\mathrm{~d}, J=3.7 \mathrm{~Hz}, 1 \mathrm{H}, \operatorname{Ar} H), 7.75(\mathrm{~d}, J=7.8 \mathrm{~Hz}, 1 \mathrm{H}$, $\operatorname{Ar} H), 7.51-7.43(\mathrm{~m}, 1 \mathrm{H}, \operatorname{Ar} H), 7.37$ (t, $J=7.5 \mathrm{~Hz}, 1 \mathrm{H}, \operatorname{Ar} H), 7.07$ (t, $J=4.8 \mathrm{~Hz}, 1 \mathrm{H}, \operatorname{Ar} H), 6.83$ $(\mathrm{d}, J=3.6 \mathrm{~Hz}, 1 \mathrm{H}, \mathrm{Ar} H) .{ }^{13} \mathbf{C}$ NMR $\left(101 \mathrm{MHz}, \mathrm{CDCl}_{3}\right) \delta 157.7,157.4,135.1,131.1,125.6,123.4$, $121.9,120.6,116.2,115.8,106.6$. NMR values are in accordance with the data reported in literature. ${ }^{[23]}$ 


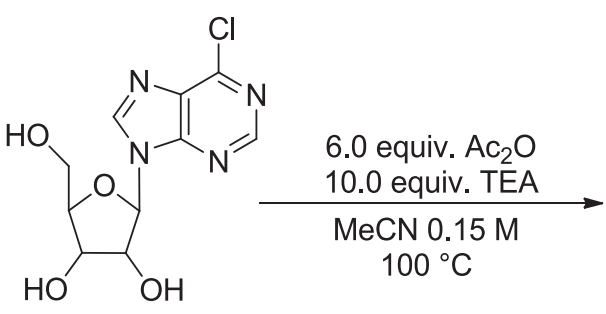

124

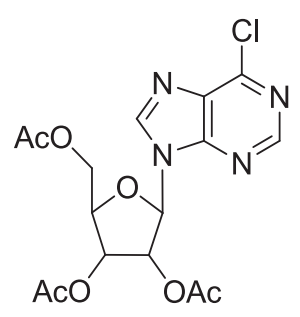

125

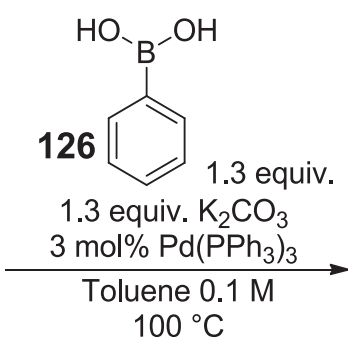

OAC

127

Following a reported procedure, ${ }^{[24]}$ commercially available $(2 R, 3 R, 4 S, 5 R)$-2-(6-chloro- $9 H$-purin9-yl)-5-(hydroxymethyl)tetrahydrofuran-3,4-diol 47 (573 mg, $2.00 \mathrm{mmol}, 1.00$ equiv.) was suspended in MeCN (12.5 mL, 0.15 M). Then Triethylamine (2.90 mL, $20.0 \mathrm{mmol}, 10.0$ equiv.) and Acetic Anhydride (1.10 mL $\mu 1,12.00 \mathrm{mmol}, 6.00$ equiv.) were added at $0^{\circ} \mathrm{C}$. After stirring for $1 \mathrm{~h}$ at room temperature, the mixture was refluxed for 5 hours. The resulting solution was evaporated to dryness and EtOAc $(30 \mathrm{~mL})$ and water $(30 \mathrm{~mL})$ were added. The organic layer was separated, dried over $\mathrm{Na}_{2} \mathrm{SO}_{4}$, filtered and concentrated under reduced pressure to give a light brown oil, which was recrystallized from EtOAc/Ether to give $(2 R, 3 R, 4 R, 5 R)$-2-(acetoxymethyl)5-(6-chloro-9H-purin-9-yl)tetrahydrofuran-3,4-diyl diacetate 48 (693 mg, $1.68 \mathrm{mmol}, 84$ \% yield)

Subsequently, to a solution of $(2 R, 3 R, 4 R, 5 R)$-2-(acetoxymethyl)-5-(6-chloro-9H-purin-9yl)tetrahydrofuran-3,4-diyl diacetate $48(500 \mathrm{mg}, 1.21 \mathrm{mmol})$ in a mixture of $4 / 1$ toluene $(12 \mathrm{~mL}$, $0.1 \mathrm{M})$ was added $\mathrm{K}_{2} \mathrm{CO}_{3}\left(218 \mathrm{mg}, 1.58 \mathrm{mmol}, 1.30\right.$ equiv.) followed by $\mathrm{Pd}\left(\mathrm{PPh}_{3}\right)_{4}(42.0 \mathrm{mg}, 30.0$ umol, $3 \mathrm{~mol} \%$ ) and phenylboronic acid 49 (192 mg, $1.58 \mathrm{mmol}, 1.30$ equiv.) under argon atmosphere in a $20 \mathrm{~mL}$ two-necked flask. The reaction mixture was refluxed for $12 \mathrm{~h}$, and then cooled to room temperature. To the reaction mixture was added sat. aqueous $\mathrm{NH}_{4} \mathrm{Cl}(15 \mathrm{~mL})$, then the mixture was extracted by EtOAc $(3 \times 5 \mathrm{~mL})$. The combined organic extracts were dried over $\mathrm{MgSO}_{4}$, filtered and and concentrated in vacuo. The resulting crude product was purified by flash chromatography (Pentane:EtOAc $4: 1)$ to afford $(2 R, 3 R, 4 R, 5 R)$-2-(acetoxymethyl)-5-(6-phenyl9H-purin-9-yl)tetrahydrofuran-3,4-diyl diacetate 50 (523 mg, $1.15 \mathrm{mmol}, 95 \%$ yield) as a white 
solid. IR v 2926 (m), 1749 (s), 1583 (s), 1566 (s), 1439 (m), 1220 (s), 1101 (m), 766 (m), 693 (m). ${ }^{1} \mathbf{H}$ NMR $\left(400 \mathrm{MHz}, \mathrm{CDCl}_{3}\right) \delta 8.95(\mathrm{~s}, 1 \mathrm{H}, \mathrm{Ar} H), 8.68(\mathrm{dd}, J=8.0,1.8 \mathrm{~Hz}, \mathrm{Ar} H), 8.21(\mathrm{~s}, 1 \mathrm{H}$, $\operatorname{Ar} H), 7.52-7.43(\mathrm{~m}, 3 \mathrm{H}, \operatorname{Ar} H), 6.22(\mathrm{~d}, J=5.3 \mathrm{~Hz}, 1 \mathrm{H}, C H), 5.95(\mathrm{t}, J=5.4 \mathrm{~Hz}, 1 \mathrm{H}, C H), 5.64$ (m, 1H, $\mathrm{CH}), 4.45-4.24\left(\mathrm{~m}, 3 \mathrm{H}, \mathrm{CH}+\mathrm{CH}_{2}\right), 2.08\left(\mathrm{~s}, 3 \mathrm{H}, \mathrm{CH}_{3}\right), 2.05\left(\mathrm{~s}, 3 \mathrm{H}, \mathrm{CH}_{3}\right), 2.00(\mathrm{~s}, 3 \mathrm{H}$, $\mathrm{CH}_{3}{ }^{13} \mathrm{C}$ NMR $\left(101 \mathrm{MHz}, \mathrm{CDCl}_{3}\right) \delta 169.9,169.2,169.0,154.7,152.1,151.6,142.5,135.0,131.2$, $130.7,129.4,128.2,86.1,79.9,72.7,70.2,62.7,20.3,20.1,20.0$. NMR values are in accordance with the data reported in literature. ${ }^{[23]}$

\subsection{Optimization of the Rh-Catalyzed Indolization of Arenes via C-H activation.}

In a vial, 2-phenylpyridine 49 (14.0 $\mu 1,0.100 \mathrm{mmol}), 1-\left(3-1\right.$-methyl- $1 H$-indole)- $1 H$ - $1 \lambda_{3}$ benzo[b]iodo-3(2H)-one 21 (1.10 equiv.), the catalyst system (1.25-5 mol\%) and the relative additive (2.5-20 mol\%) were dissolved in the appropriate dry solvent $(0.1 \mathrm{M})$ under nitrogen. The reaction mixture was degassed (freeze-thaw-pump) and then stirred at the reported $\mathrm{T}$ in ${ }^{\circ} \mathrm{C}$ overnight. The reaction mixture was then allowed to cool to r.t., the organic layer was washed with sat. aqueous $\mathrm{NaHCO}_{3}(2 \mathrm{~mL})$, and the solvent was removed under reduced pressure. Flash column chromatography (Pentane:EtOAc 4:1) afforded the desired product 52 (see compound 52's characterization for all the chemical data).

Table S3: Screening of solvents

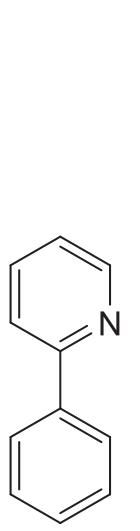

49<smiles>CCCCOC(=O)c1ccccc1[IH]c1cn(C)c2ccccc12</smiles>

$10 \mathrm{~mol} \% \mathrm{Zn}(\mathrm{OTf})_{2}$ $5 \mathrm{~mol} \%\left[\mathrm{Rh}\left(\mathrm{Cp}^{*} \mathrm{Cl}_{2}\right)\right]_{2}$ solvent $0.1 \mathrm{M}$ r.t

\begin{tabular}{ccc}
\hline Entry & Solvent & Yield\% $^{\mathbf{a}}$ \\
\hline 1 & DCM & $25 \%$
\end{tabular}


$\mathrm{EtOH}$

5

TFE

$16 \%$

6 Chlorobenzene

7

\section{1,2-Chlorobenzene}

8

Toluene

9

$\operatorname{DMF}\left(110^{\circ} \mathrm{C}\right)$

$66 \%$

a) Substrate $49(0.100 \mathrm{mmol})$, IndoleBX $21(0.110 \mathrm{mmol}),\left[\mathrm{Rh}\left(\mathrm{Cp}^{*} \mathrm{Cl}_{2}\right)\right]_{2}$ (5 mol\%), $\mathrm{Zn}(\mathrm{OTf})_{2}(10 \mathrm{~mol} \%)$ and solvent $(0.1 \mathrm{M})$ at $25^{\circ} \mathrm{C}$. Isolated yield after flash chromatography is given.

Table S4: Screening of additives<smiles>c1ccc(-c2ccccn2)cc1</smiles>

49

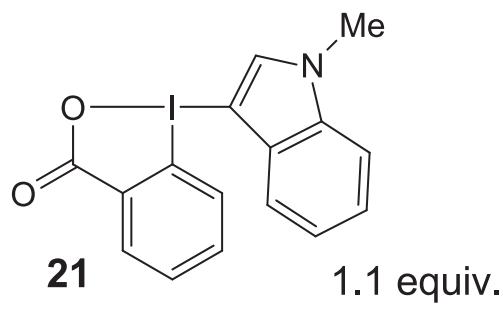

$10 \mathrm{~mol} \%$ additive $5 \mathrm{~mol} \%\left[\mathrm{Rh}\left(\mathrm{Cp}^{*} \mathrm{Cl}_{2}\right)\right]_{2}$ DCE $0.1 \mathrm{M}$

r.t<smiles>Cn1cc(-c2ccccc2-c2ccccn2)c2ccccc21</smiles>

52

\begin{tabular}{ccc}
\hline Entry & Additive & Yield\%a $^{\mathbf{a}}$ \\
\hline 1 & - & - \\
2 & $\mathrm{Zn}(\mathrm{OTf})_{2}$ & $55 \%{ }^{\mathrm{b}}$ \\
3 & $\mathrm{Sc}(\mathrm{OTf})_{3}$ & $56 \% 0^{\mathrm{c}}$ \\
4 & $\mathrm{~K}_{2} \mathrm{CO}_{3}$ & $28 \%$ \\
5 & $\mathrm{Zn}$ & $56 \%$ \\
6 & $\left.\mathrm{AgNT}_{2}\right)_{2}$ & - \\
7 & $\mathrm{AgSbF}_{6}{ }^{\mathrm{d}}$ & $17 \%$
\end{tabular}




\begin{tabular}{ccc}
8 & NaOAc & $69 \%$ \\
9 & KOAc & $37 \%$ \\
$\mathbf{1 0}$ & NaOPiv & $\mathbf{7 2 \%}$ \\
11 & KOPiv & $49 \%$ \\
12 & CsOPiv & $36 \%$ \\
\hline a) Substrate $49(0.100 \mathrm{mmol})$, IndoleBX $21(0.110 \mathrm{mmol}),\left[\mathrm{Rh}\left(\mathrm{Cp}^{*} \mathrm{Cl}_{2}\right)\right]_{2}(5$ \\
mol\%), additive $(10 \mathrm{~mol} \%)$ and DCE $(0.1 \mathrm{M})$ at $25^{\circ} \mathrm{C}$. Isolated yield after \\
flash chromatography is given. b) incomplete conversion, remaining starting \\
material completely recovered. c) decomposition observed. d) $\mathrm{T}$ of the \\
reaction is $50^{\circ} \mathrm{C}$.
\end{tabular}

Table S5: Screening of the catalyst:additive ratio at different $\mathrm{T}^{\circ} \mathrm{C}$.<smiles>c1ccc(-c2ccccn2)cc1</smiles>

49

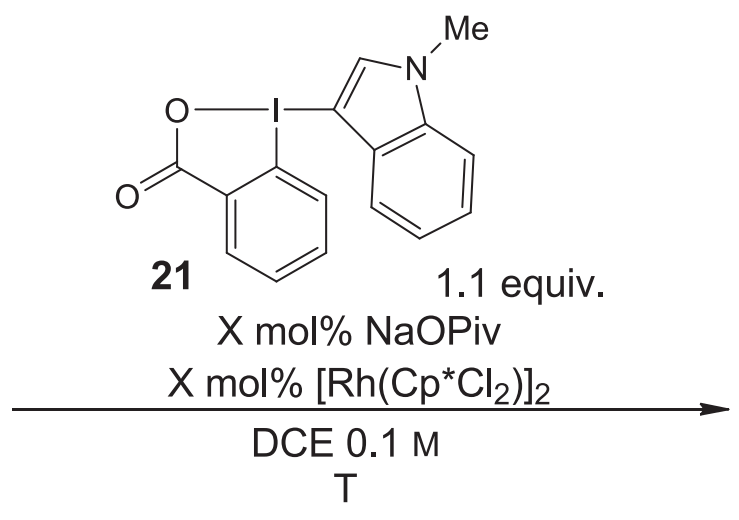

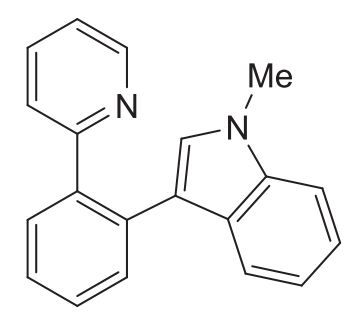

52

\begin{tabular}{ccccc}
\hline Entry & Catalyst $(\mathbf{m o l} \%)$ & Additive $(\mathbf{m o l} \%)$ & $\mathbf{T}^{\circ} \mathbf{C}$ & Yield\% $^{\mathbf{a}}$ \\
\hline 1 & {$\left[\mathrm{Rh}\left(\mathrm{Cp}^{*} \mathrm{Cl}_{2}\right)_{2}\right]$} & NaOPiv $(2.5)$ & r.t. & traces $^{\mathrm{b}}$ \\
& $(1.25) / \mathrm{AgSbF}_{6}(2.5)$ & & & \\
2 & {$\left[\mathrm{Rh}\left(\mathrm{Cp}^{*} \mathrm{Cl}_{2}\right)_{2}\right]$} & NaOPiv $(10)$ & r.t. & traces $^{\mathrm{b}}$ \\
& $(1.25) / \mathrm{AgSbF}_{6}(10)$ & & & \\
3 & {$\left[\mathrm{Rh}\left(\mathrm{Cp}^{*} \mathrm{Cl}_{2}\right)_{2}\right]$} & NaOPiv $(10)$ & $40^{\circ} \mathrm{C}$ & traces $^{\mathrm{b}}$ \\
& $(1.25) / \mathrm{AgSbF}_{6}(10)$ & & & \\
& {$\left[\mathrm{Rh}\left(\mathrm{Cp}^{*} \mathrm{Cl}_{2}\right)_{2}\right]$} & NaOPiv $(10)$ & $50^{\circ} \mathrm{C}$ & $37 \%{ }^{\mathrm{b}}$
\end{tabular}


5

7

9
[ $\left.\mathrm{Rh}\left(\mathrm{Cp} * \mathrm{Cl}_{2}\right)_{2}\right]$

(2.5)/ $/ \mathrm{AgSbF}_{6}(5)$

$\left[\mathrm{Rh}\left(\mathrm{Cp}^{*} \mathrm{Cl}_{2}\right)_{2}\right]$

(2.5)/ $\operatorname{AgSbF}_{6}(10)$

$\left[\mathrm{Rh}\left(\mathrm{Cp} * \mathrm{Cl}_{2}\right)_{2}\right]$

(2.5)/ $/ \operatorname{AgSbF}_{6}(10)$

$$
\left[\mathbf{R h}\left(\mathbf{C p}^{*} \mathbf{C l}_{2}\right)_{2}\right]
$$

(2.5)/AgSbF 6 (10)

$$
\left[\mathrm{Rh}\left(\mathrm{Cp}^{*} \mathrm{Cl}_{2}\right)_{2}\right](5) / \mathrm{AgSbF}_{6}
$$

$\mathrm{NaOPiv}(5)$

r.t.

traces $^{\mathrm{c}}$

NaOPiv (10)

r.t.

$50^{\circ} \mathrm{C}$

$82 \%$

NaOPiv (10)

NaOPiv (10)

$80^{\circ} \mathrm{C}$

$85 \%$

NaOPiv (10)

r.t.

$90 \%$

a)Substrate 49 (0.100 mmol), IndoleBX 21 (0.110 mmol), [Rh(Cp*Cl $]_{2}(\mathbf{X ~ m o l} \%), \mathrm{NaOPiv}(\mathbf{X} \mathrm{mol} \%)$ and $\operatorname{DCE}(0.1 \mathrm{M})$ at $25{ }^{\circ} \mathrm{C}$. Isolated yield after flash chromatography is given. b) the reaction time was 48 hours, hypervalent iodine decomposition was observed.

\subsection{Control experiments for the Indolization of Arenes via C-H activation.}

In order to assess the superiority of our reagents in catalysis compared to other indole-transfer reagents already known in cross-coupling reactions, we tested the latter under different sets of conditions. Substrates $\mathbf{1 4 , 5 0}$ and $\mathbf{5 1}$ are commercially available, while compound $\mathbf{5 3}$ needed to be prepared and immediately used in the catalytic process.<smiles>Cn1ccc2ccccc21</smiles>

14<smiles>Cn1cc(Br)c2ccccc21</smiles>

50<smiles>Cn1cc(I)c2ccccc21</smiles>

51<smiles></smiles>

53

Substrates 50, 51 and $\mathbf{5 3}$ were tested under our optimized conditions (table S6, entries 1-3) at different temperatures (r.t.-50-60-110 ${ }^{\circ} \mathrm{C}$ ): no conversion was observed. The hypervalent indolinium salt $\mathbf{5 3}$ was also tested in presence of $\mathrm{NaSbF}_{6}$ (table S6, entry 4) as an alternative salt to promote the exchange of $\mathrm{BF}_{4}^{-}$counteranion with $\mathrm{SbF}_{6}^{-}$, but no conversion was observed. Substrates 50 and 51 were then tested under established conditions for Pd-catalyzed cross couplings of C3halogenated indoles. 3- Bromo-N-methylindole 50 was tested under Hartwig Pd-catalyzed amination conditions $^{[25]}$ (table S6, entry 5), carbonylative Sonogashira conditions ${ }^{[26]}$ (table S6, 
entry 6) and Heck conditions ${ }^{[27]}$ (table S6, entry 7): the desired product was never observed. Furthermore, when 3-Iodo- $N$-methylindole 51 was tested under Suzuki and Sonogashira cross coupling conditions ${ }^{[28]}$ (table S6, entries 8-9) no product was detected.

In Table $S 7$ oxidative methods were examined (table $S 7$, entries 1,4), ${ }^{[29]}$ Shi conditions (table $S 7$, entries 2,5), ${ }^{[30]}$ and Fagnou conditions (table S7, entries 3,6); ${ }^{[31]}$ the desired compound was never observed.

Table S6: Control experiments (I)

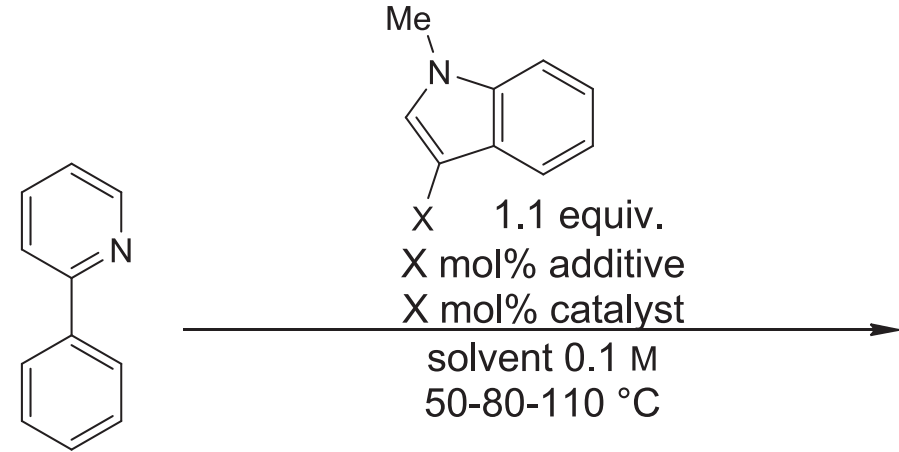

49

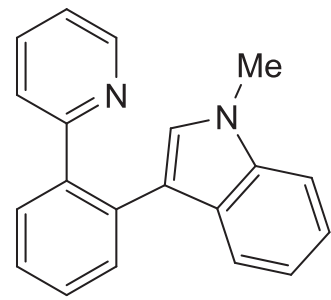

52

\begin{tabular}{|c|c|c|c|c|c|}
\hline Entry & $\bar{X}$ & Catalyst (mol\%) & Additive (mol\%) & Solvent (M) & Yield $\%{ }^{a}$ \\
\hline 1 & H (14) & $\begin{array}{c}{\left[\mathrm{Rh}\left(\mathrm{Cp}^{*} \mathrm{Cl}_{2}\right)_{2}\right]} \\
(2.5) / \mathrm{AgSbF}_{6}(10)\end{array}$ & NaOPiv (10) & $\operatorname{DCE}(0.1 \mathrm{M})$ & - \\
\hline 2 & I (51) & $\begin{array}{c}{\left[\mathrm{Rh}\left(\mathrm{Cp}^{*} \mathrm{Cl}_{2}\right)_{2}\right]} \\
(2.5) / \mathrm{AgSbF}_{6}(10)\end{array}$ & NaOPiv (10) & $\operatorname{DCE}(0.1 \mathrm{M})$ & - \\
\hline 3 & $\mathrm{I}^{(\mathrm{III})}(\mathbf{5 3})$ & $\begin{array}{c}{\left[\mathrm{Rh}\left(\mathrm{Cp}^{*} \mathrm{Cl}_{2}\right)_{2}\right]} \\
(2.5) / \mathrm{NaSbF}_{6}(10)\end{array}$ & NaOPiv (10) & $\operatorname{DCE}(0.1 \mathrm{M})$ & - \\
\hline 4 & $\mathrm{I}^{(\mathrm{III})}(\mathbf{5 3})$ & $\begin{array}{c}{\left[\mathrm{Rh}\left(\mathrm{Cp}^{*} \mathrm{Cl}_{2}\right)_{2}\right]} \\
(2.5) / \mathrm{AgSbF}_{6}(10)\end{array}$ & NaOPiv (10) & $\operatorname{DCE}(0.1 \mathrm{M})$ & - \\
\hline 5 & $\operatorname{Br}(\mathbf{5 0})$ & $\begin{array}{l}\mathrm{Pd}(\mathrm{dba})_{2}(5) / \\
\mathrm{PPh}_{3}(5)\end{array}$ & - & Toluene $(0.2 \mathrm{M})$ & - \\
\hline 6 & $\operatorname{Br}(\mathbf{5 0})$ & $\begin{array}{c}\mathrm{PdCl}_{2}(5) / \\
\text { XanthPhos (5) }\end{array}$ & TEA ( 3 equiv.) & Dioxane $(0.2 \mathrm{M})$ & - \\
\hline
\end{tabular}




\begin{tabular}{|c|c|c|c|c|c|}
\hline 7 & $\operatorname{Br}(\mathbf{5 0})$ & $\begin{array}{l}\mathrm{Pd}(\mathrm{OAc})_{2}(20) / \\
\mathrm{P}(o-\mathrm{Tol})_{3}(20)\end{array}$ & TEA ( 3 equiv.) & Toluene $(0.2 \mathrm{M})$ & - \\
\hline 8 & I (51) & $\mathrm{PdCl}_{2} \mathrm{PPh}_{3}(5)$ & $\begin{array}{c}\text { CuI (10)/ TEA ( } 3 \\
\text { equiv.) }\end{array}$ & DMF (0.1 M) & - \\
\hline 9 & I (51) & $\mathrm{Pd}\left(\mathrm{PPh}_{3}\right)_{3}(2.5)$ & $\mathrm{Na}_{2} \mathrm{CO}_{3}$ (1 equiv.) & DMF (0.1 M) & - \\
\hline
\end{tabular}

Table S7: Control experiments (II)

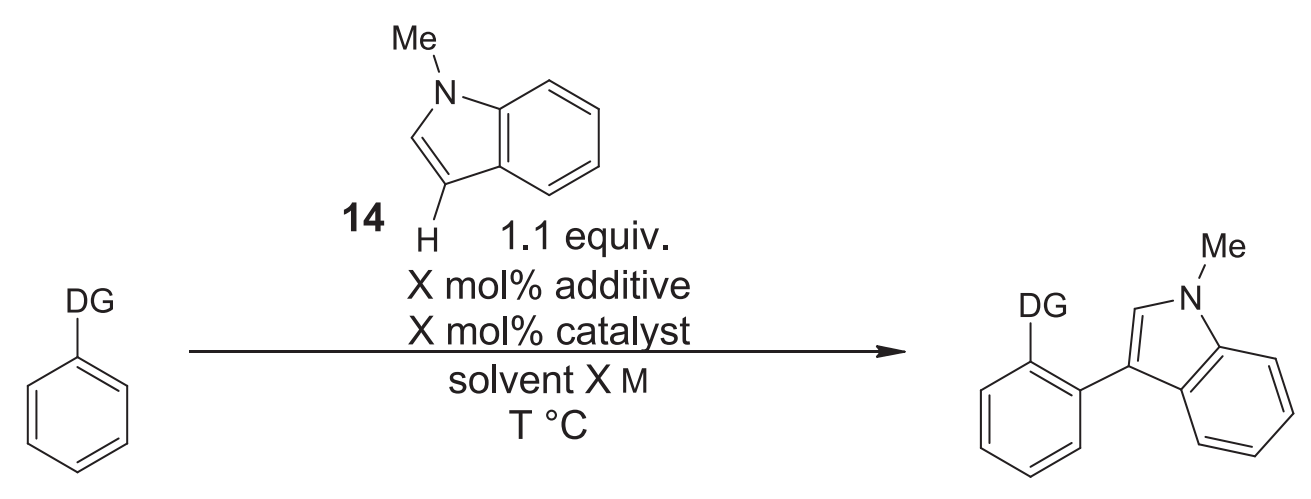

\begin{tabular}{|c|c|c|c|c|c|c|c|}
\hline Entry & Substrate & Equiv. & $\begin{array}{c}\text { Equiv. } \\
8 \mathrm{8a}\end{array}$ & Catalyst (mol\%) & Additive (mol\%) & $\begin{array}{c}\text { Solvent (M)/ } \\
\mathbf{T}^{\circ} \mathbf{C}\end{array}$ & Yield\% ${ }^{\mathrm{a}}$ \\
\hline 1 & & 1 & 20 & $\begin{array}{c}{\left[\mathrm{Rh}\left(\mathrm{Cp}^{*} \mathrm{Cl}_{2}\right)_{2}\right]} \\
(2.5) / \operatorname{CsOPiv}(20)\end{array}$ & $\begin{array}{c}\mathrm{PivOH}(50) \\
2.0 \text { equiv. } \\
\mathrm{C}_{6} \mathrm{Br}_{6} / 2.2 \text { equiv. } \\
\mathrm{Cu}(\mathrm{OAc})_{2}\end{array}$ & $\begin{array}{c}2 \mathrm{Cl}-p \text {-xylene } \\
(0.33 \mathrm{M}) / 140{ }^{\circ} \mathrm{C}\end{array}$ & - \\
\hline 2 & & 1 & 6.0 & $\mathrm{Pd}(\mathrm{OAc})_{2}(10)$ & $\begin{array}{c}\mathrm{Cu}(\mathrm{OTf})_{2}(20) \\
\mathrm{O}_{2} 1 \mathrm{~atm} .\end{array}$ & $\begin{array}{c}\mathrm{EtCOOH} \\
(0.2 \mathrm{M}) / 120^{\circ} \mathrm{C}\end{array}$ & - \\
\hline 3 & & 60 & 1 & $\operatorname{Pd}(\mathrm{TFA})_{2}(5)$ & $\begin{array}{c}3.0 \text { equiv. } \\
\mathrm{Cu}(\mathrm{OAc})_{2} / 6.0 \\
\text { equiv. } \mathrm{PivOH}\end{array}$ & $\begin{array}{c}\text { neat in arene } \\
(0.15 \mathrm{M})\end{array}$ & - \\
\hline
\end{tabular}

\begin{tabular}{|c|c|c|c|c|c|}
\hline & & & & PivOH (50) & \\
\hline 4 & 1 & 20 & $\begin{array}{c}{\left[\mathrm{Rh}\left(\mathrm{Cp}^{*} \mathrm{Cl}_{2}\right)_{2}\right]} \\
(2.5) / \mathrm{CsOPiv}(20)\end{array}$ & $\begin{array}{c}2.0 \text { equiv. } \\
\mathrm{C}_{6} \mathrm{Br}_{6} / 2.2 \text { equiv. } \\
\mathrm{Cu}(\mathrm{OAc})_{2}\end{array}$ & $\begin{array}{c}\text { 2Cl-p-xylene } \\
(0.33 \mathrm{M}) / 140^{\circ} \mathrm{C}\end{array}$ \\
\hline
\end{tabular}




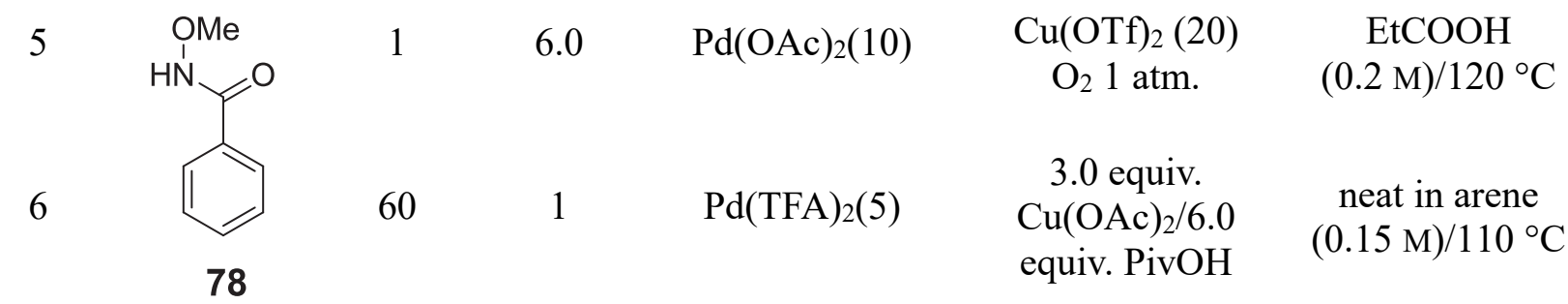

a)Reaction performed on $0.1 \mathrm{mmol}$ of the limiting reagent; substrate (X mmol), Indole 14 (X mmol), Catalyst (X mol\%), Additive (X mol\%) and Solvent (X M) at $\mathrm{T}^{\circ} \mathrm{C}$.

Finally, in Table $S 8$ are reported control experiments employing conditions suitable for hypervalent iodine reagents such as Kita conditions (table S8, entry 1), ${ }^{[32]}$ Sanford conditions (table S8, entry $2),{ }^{[33]}$ and Daugulis conditions (table $S 8$, entry 3$){ }^{[34]}$ the desired compounds was not observed also in this case; All conditions screened in Tables $S 6, S 7$ and $S 8$ failed to afford the desired product, thus demonstrating the unique reactivity of our reagents.

Table S8: Control experiments (III)<smiles>[X]c1ccc2c(c1)I(c1cn(C)c3ccccc13)OC2=O</smiles>
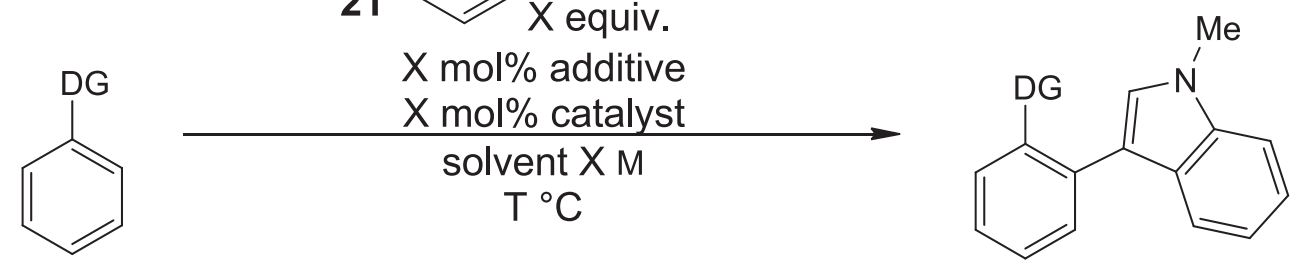

\begin{tabular}{cccccccc}
\hline Entry & Substrate & Equiv. & $\begin{array}{c}\text { Equiv. } \\
\mathbf{8 a}\end{array}$ & Catalyst (mol\%) & Additive (mol\%) & $\begin{array}{c}\text { Solvent (M)/ } \\
\mathbf{T}^{\circ} \mathbf{C}\end{array}$ & Yield\% $^{\mathbf{a}}$ \\
\hline 1 & 1.5 & 1 & - & 2.0 equiv. TMSBr & HFIP $(0.1 \mathrm{M})$ & - \\
2 & 1 & 1.5 & $\operatorname{Pd}(\mathrm{OAc})_{2}(5)$ & - & $\begin{array}{c}\mathrm{MeCOOH} \\
(0.1 \mathrm{M}) / 110^{\circ} \mathrm{C}\end{array}$ \\
\hline
\end{tabular}




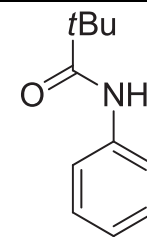

\subsection{Scope of the Rh-Catalyzed Indolization via C-H activation.}

\section{General Procedures GP3-GP4 for Rh-Catalyzed Hetero-arylation via C-H activation}
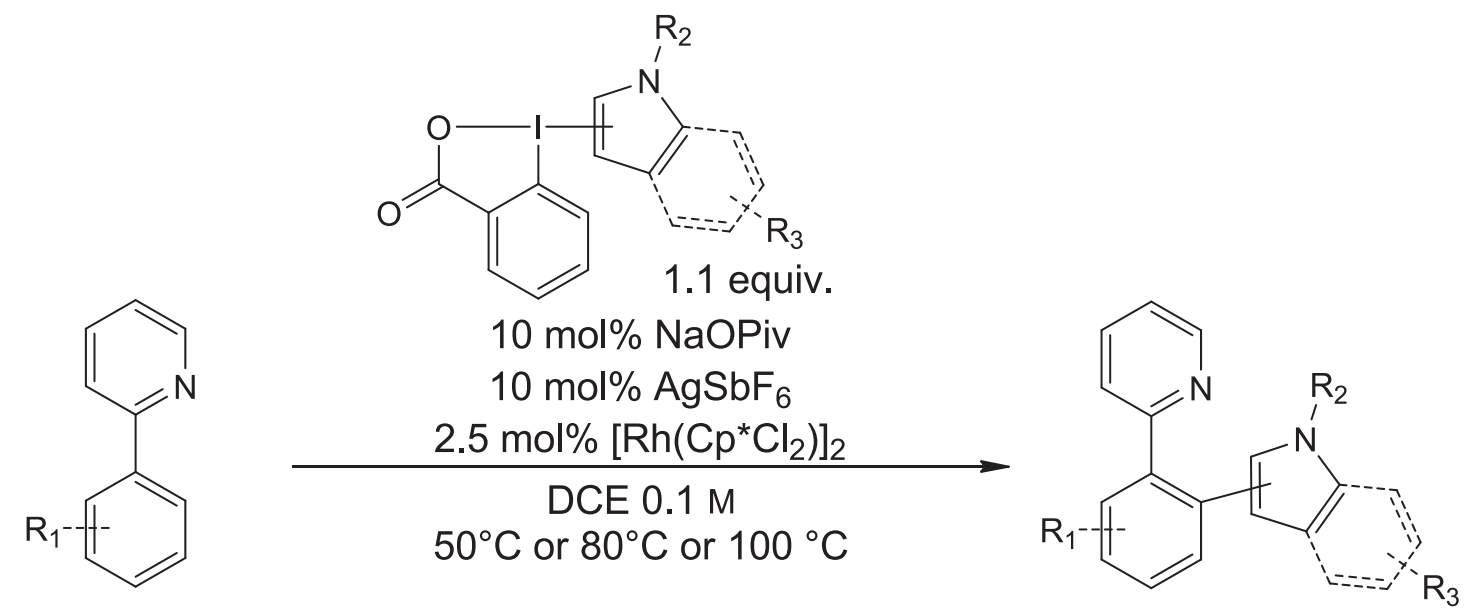

GP3: In a vial, the corresponding aryl-pyridine ( $0.300 \mathrm{mmol}, 1.00$ equiv. $)$, the relative heterocyclic hypervalent iodine reagent $(0.330 \mathrm{mmol}, 1.10$ equiv. $),\left[\mathrm{Rh}\left(\mathrm{Cp}^{*} \mathrm{Cl}_{2}\right)\right]_{2}(4.60 \mathrm{mg}, 7.50 \mu \mathrm{mol}, 2.5$ mol\%), $\operatorname{AgSbF}_{6}(10.3 \mathrm{mg}, 30.0 \mu \mathrm{mol}, 10 \mathrm{~mol} \%$ ) and NaOPiv (3.70 mg, $30.0 \mu \mathrm{mol}, 10 \mathrm{~mol} \%$ ) were dissolved in dry 1,2-DCE $(3 \mathrm{ml}, 0.1 \mathrm{M})$ under nitrogen. the reaction mixture was degassed (freezethaw-pump) and stirred at the reported $\mathrm{T}$ in ${ }^{\circ} \mathrm{C}$ overnight. The reaction mixture was then allowed to cool to r.t., the organic layer was washed with sat. aquoeus $\mathrm{NaHCO}_{3}(2 \mathrm{ml})$, and the solvent was removed under reduced pressure. Flash column chromatography (Pentane:EtOAc) afforded the desired products 52-70, 75. 


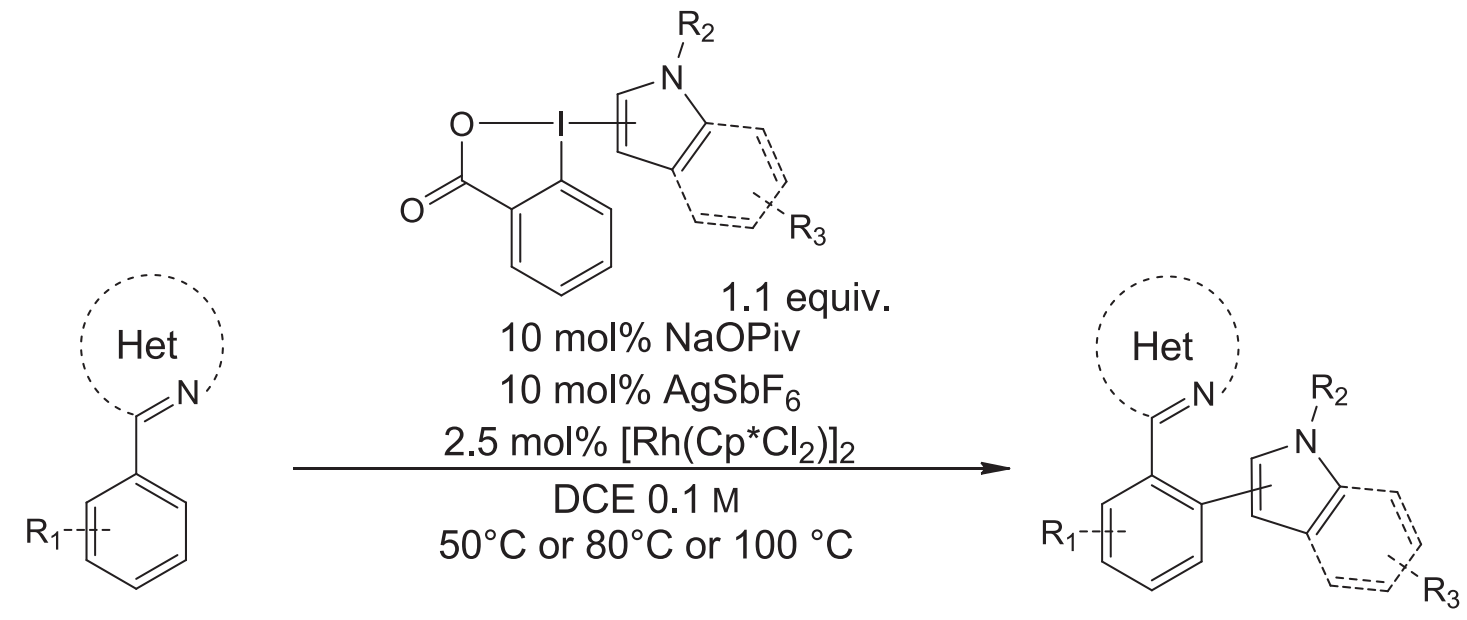

GP4: In a screw capped vial, the corresponding heterocycle $(0.300 \mathrm{mmol}, 1.00$ equiv. $)$, the relative heterocyclic hypervalent iodine reagent 21 (0.330 mmol, 1.10 equiv.), $\left.\left[\mathrm{Rh}_{(\mathrm{Cp}} \mathrm{Cl}_{2}\right)\right]_{2}(4.60 \mathrm{mg}$, $7.50 \mu \mathrm{mol}, 2.5 \mathrm{~mol} \%), \mathrm{AgSbF}_{6}(10.3 \mathrm{mg}, 30.0 \mu \mathrm{mol}, 10 \mathrm{~mol} \%)$ and NaOPiv (3.70 mg, $30.0 \mu \mathrm{mol}$, $10 \mathrm{~mol} \%$ ) were dissolved in dry 1,2-DCE $(3 \mathrm{ml}, 0.1 \mathrm{M})$ under nitrogen. the reaction mixture was degassed (freeze-thaw-pump) and stirred at the reported $\mathrm{T}$ in ${ }^{\circ} \mathrm{C}$ overnight. The reaction mixture was then allowed to cool to r.t., the organic layer was washed with sat. aqueous $\mathrm{NaHCO}_{3}(2 \mathrm{~mL})$, and the solvent was removed under reduced pressure. Flash column chromatography (Pentane:EtOAc) afforded the desired products 71-74, 76-77. 


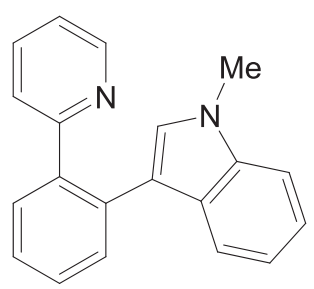

52

$82 \%$ yield<smiles>Cn1cccc1-c1ccccc1-c1ccccn1</smiles>

61

$83 \%$ yield $^{b}$<smiles>Cn1cc(-c2ccccc2-c2ccccn2)c2cc(I)ccc21</smiles>

59

$74 \%$ yield<smiles>c1ccc(-c2ccccc2-c2cc[nH]c2)nc1</smiles>

65

$79 \%$ yield $^{b}$<smiles>c1ccc(-c2ccccc2-c2c[nH]c3ccccc23)nc1</smiles>

54

$74 \%$ yield $^{d}$<smiles>Cn1ccc(-c2ccccc2-c2ccccn2)c1</smiles>

62

$85 \%$ yield $^{b}$

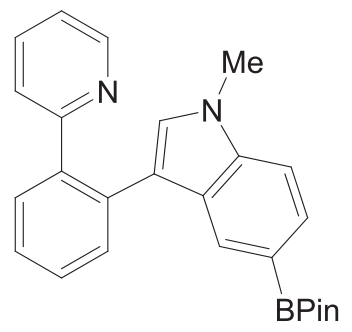

60

$59 \%$ yield

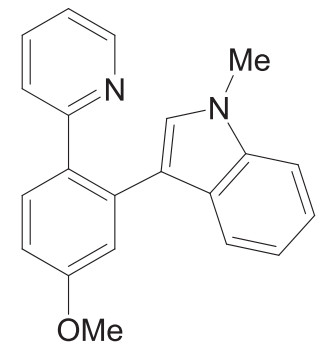

66

$88 \%$ yield

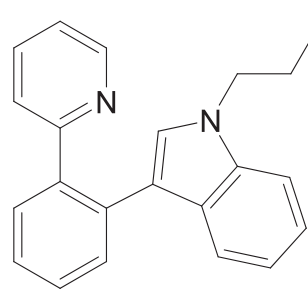

55

$74 \%$ yield $^{b}$

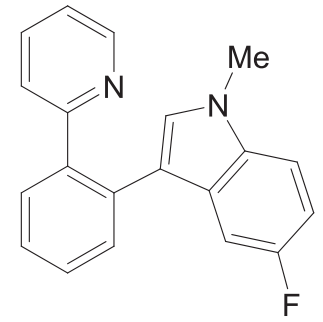

57

$73 \%$ yield<smiles>c1ccc(Cn2cccc2-c2ccccc2-c2ccccn2)cc1</smiles>

63

$68 \%$ yield $^{b}$

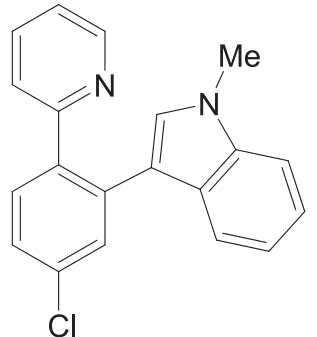

67

$85 \%$ yield

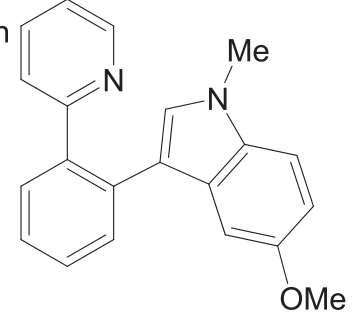

56

$89 \%$ yield

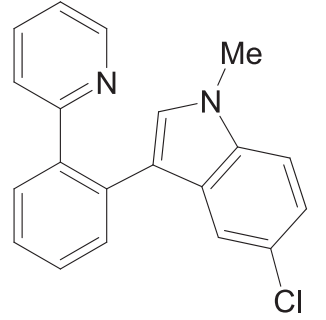

58

$81 \%$ yield

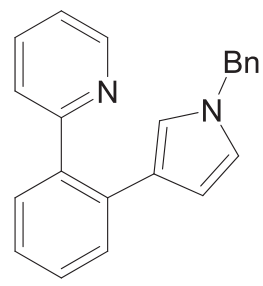

64 $58 \%$ yield $^{\text {b }}$

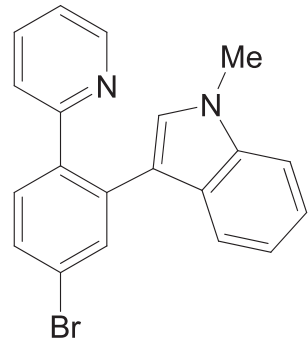

68

$84 \%$ yield

Figure S8: Scope with Aryl-pyridines. 


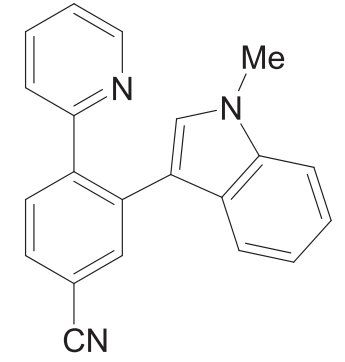

69

$78 \%$ yield $^{\mathrm{b}}$

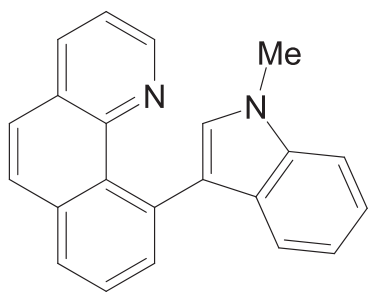

73

$76 \%$ yield

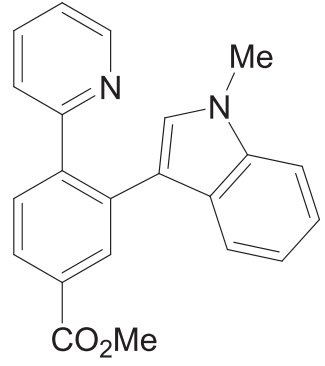

70

$94 \%$ yield

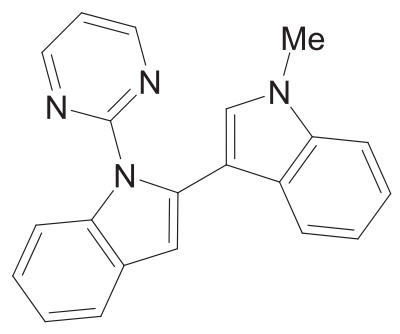

74

$82 \%$ yield

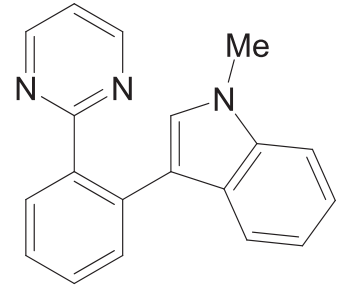

71

$81 \%$ yield $^{b}$

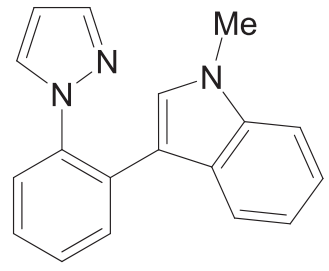

72

$72 \%$ yield

Figure S9: Scope with Aryl-pyridines (I).

\section{1-Methyl-3-(2-(pyridin-2-yl)phenyl)-1H-indole (52)}<smiles>Cn1cc(-c2ccccc2-c2ccccn2)c2ccccc21</smiles>

52

Starting from commercially available 2-phenylpyridine 49 (43.0 $\mu 1,0.300$ mmol, 1.00 equiv.) and with 1-(3-1-methyl-1H-indole)-1H-1 $\lambda_{3} \quad-$ benzo[b]iodo-3(2H)-one 21 (124 mg, $0.330 \mathrm{mmol}, 1.10$ equiv.) at $50{ }^{\circ} \mathrm{C}, 2-$ (2-(1-methyl-1H-pyrrol-2-yl)phenyl)pyridine 52 (60.0 mg, $0.256 \mathrm{mmol}$, $85 \%$ yield) was obtained as a pale yellow oil. Rf: 0.48 (Pentane:EtOAc 4:1). IR $v 3057$ (w), 2934 (w), 1725 (w), 1586 (s), 1545 (m), 1461 (s), 1425 (s), 1377 (s), 1330 (m), 1219 (m), 1162 (w), 1091 (w), 1024 (w), 942 (w), 910 (w). ${ }^{\mathbf{1}}$ H NMR (400 MHz, $\left.\mathrm{CDCl}_{3}\right) \delta 8.65(\mathrm{~m}, 1 \mathrm{H}, \mathrm{Ar} H), 7.73(\mathrm{dd}, J=7.4,1.7 \mathrm{~Hz}, 1 \mathrm{H}, \mathrm{Ar} H), 7.59$ (m, 1H, $\left.\mathrm{Ar} H\right), 7.52-7.38$ (m, 3H, ArH), $7.35-7.22(\mathrm{~m}, 2 \mathrm{H}, \operatorname{Ar} H), 7.19(\mathrm{ddd}, J=8.2,7.0,1.1 \mathrm{~Hz}, 1 \mathrm{H}, \operatorname{Ar} H), 7.11-6.94(\mathrm{~m}$, $3 \mathrm{H}, \mathrm{ArH}), 6.71(\mathrm{~s}, 1 \mathrm{H}, \mathrm{NCHC}), 3.70\left(\mathrm{~s}, 3 \mathrm{H}, \mathrm{NCH}_{3}\right) .{ }^{13} \mathrm{C}$ NMR $\left(101 \mathrm{MHz}, \mathrm{CDCl}_{3}\right) \delta 159.9,149.3$, $139.8,136.8,135.1,133.3,131.0,130.5,128.4,128.2,127.0,126.7,124.9,121.6,121.2,119.9$, 119.5, 115.4, 109.1, 32.7. HR-ESI-MS 285.1388 ([M+H] $]^{+}, \mathrm{C}_{20} \mathrm{H}_{17} \mathrm{~N}_{2}{ }^{+}$; calc. for 285.1386). 


\section{3-(2-(pyridin-2-yl)phenyl)-1H-indole (54)}<smiles>c1ccc(-c2ccccc2-c2c[nH]c3ccccc23)nc1</smiles>

54

Starting from commercially available 2-phenylpyridine 8 (43.0 $\mu 1,0.300$ mmol, 1.00 equiv.) and with 1 -(3-1H-indole)- $1 H-1 \lambda_{3}$-benzo[b]iodo-3(2H)one 25 (120 mg, $0.330 \mathrm{mmol}, 1.10$ equiv.) at $50{ }^{\circ} \mathrm{C}, 2-(2-(1-$ methyl- $1 H$ pyrrol-2-yl)phenyl)pyridine 54 (60.3 $\mathrm{mg}, 0.223 \mathrm{mmol}, 74 \%$ yield) was obtained as a slightly brown foam. Rf: 0.30 (Pentane:EtOAc 4:1). IR $v 3409$ (w), $3170(\mathrm{w}), 3058(\mathrm{w}), 2921(\mathrm{w}), 1668(\mathrm{w}), 1600(\mathrm{~m}), 1589(\mathrm{~s}), 1544(\mathrm{w})$, 1489 (w), 1464 (s), 1332 (w), 1245 (m), 1153 (w), 1098 (w), 910 (m). ${ }^{1}$ H NMR (400 MHz, CDCl $)$ $\delta 8.63(\mathrm{~m}, 1 \mathrm{H}, \operatorname{Ar} H), 8.40(\mathrm{~s}, 1 \mathrm{H}, \mathrm{NH}), 7.72(\mathrm{dd}, J=7.3,1.8 \mathrm{~Hz}, 1 \mathrm{H}, \operatorname{Ar} H), 7.60(\mathrm{dd}, J=7.3,1.8$ $\mathrm{Hz}, 1 \mathrm{H}, \operatorname{Ar} H$ ), $7.51-7.39$ (m, 3H, ArH), $7.33-7.22$ (m, 2H, ArH), 7.14 (ddd, J= 8.2, 6.9, $1.2 \mathrm{~Hz}$, 1H, $\operatorname{Ar} H), 7.02(\mathrm{~m}, 3 \mathrm{H}, \mathrm{ArH}), 6.76(\mathrm{~d}, J=2.5 \mathrm{~Hz}, 1 \mathrm{H}, \mathrm{NHCHC}) .{ }^{13} \mathbf{C} \mathbf{N M R}\left(101 \mathrm{MHz}, \mathrm{CDCl}_{3}\right) \delta$ $159.8,149.0,139.8,135.9,135.3,133.3,131.0,130.5,128.5,126.9,126.6,125.0,123.7,122.0$, 121.3, 119.9, 119.7, 116.7, 111.0. HR-ESI-MS $271.1233\left([\mathrm{M}+\mathrm{H}]^{+}, \mathrm{C}_{19} \mathrm{H}_{15} \mathrm{~N}_{2}{ }^{+}\right.$; calc. for 271.1230).

\section{1-(3-Phenylpropyl)-3-(2-(pyridin-2-yl)phenyl)-1H-indole (55)}

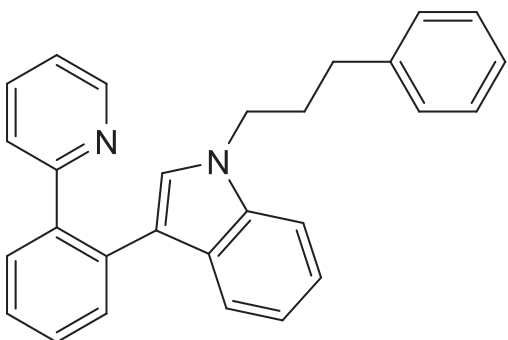

55

Starting from commercially available 2-phenylpyridine 49 (43.0 $\mu 1,0.300 \mathrm{mmol})$ and with 1-(3-1-(3-phenylpropyl)-1H-indole)$1 H$ - $1 \lambda_{3}$-benzo[b]iodo-3(2H)-one $32(159 \mathrm{mg}, 0.330 \mathrm{mmol}, 1.10$ equiv.) at $80{ }^{\circ} \mathrm{C}, 1-(3-$ phenylpropyl)-3-(2-(pyridin-2-yl)phenyl)$1 H$-indole 55 ( $86.0 \mathrm{mg}, 0.221 \mathrm{mmol}, 74 \%$ yield) was obtained as an orange oil. Rf: 0.48 (Pentane:EtOAc 4:1). IR $v 3059$ (w), 3027 (w), 2932 (w), 1602 (w), 1585 (m), 1547 (w), 1496 (w), 1462 (s), 1424 (w), 1392 (w), 1372 (w), 1334 (w), 1167 (w), 1024 (w), 911 (w). ${ }^{1}$ H NMR (400 MHz, CDCl $) \delta 8.67$ (m, 1H, ArH), 7.76 (dd, $J=7.4,1.7 \mathrm{~Hz}, 1 \mathrm{H}, \operatorname{Ar} H), 7.67(\mathrm{dd}, J=7.4,1.5 \mathrm{~Hz}, 1 \mathrm{H}, \operatorname{Ar} H), 7.58(\mathrm{~d}, J=7.9 \mathrm{~Hz}, 1 \mathrm{H}, \operatorname{Ar} H)$, $7.51(\mathrm{td}, J=7.4,1.7 \mathrm{~Hz}, 1 \mathrm{H}, \mathrm{Ar} H), 7.47$ (td, $J=7.4,1.5 \mathrm{~Hz}, 1 \mathrm{H}, \mathrm{Ar} H), 7.34-7.19$ (m, 6H, ArH), $7.09(\mathrm{~m}, 3 \mathrm{H}, \mathrm{ArH}), 7.06-7.01(\mathrm{~m}, 2 \mathrm{H}, \mathrm{ArH}), 6.71\left(\mathrm{~s}, 1 \mathrm{H}, \mathrm{CH}_{2} \mathrm{NCHC}\right), 4.04(\mathrm{t}, J=6.8 \mathrm{~Hz}, 2 \mathrm{H}$, $\mathrm{PhCH}_{2} \mathrm{CH}_{2} \mathrm{CH}_{2} \mathrm{~N}$ ), $2.48\left(\mathrm{dd}, J=8.6,6.7 \mathrm{~Hz}, 2 \mathrm{H}, \mathrm{PhCH}_{2} \mathrm{CH}_{2} \mathrm{CH}_{2} \mathrm{~N}\right.$ ), $2.08(\mathrm{dq}, J=9.0,6.9 \mathrm{~Hz}, 2 \mathrm{H}$, $\left.\mathrm{PhCH}_{2} \mathrm{CH}_{2} \mathrm{CH}_{2} \mathrm{~N}\right) .{ }^{13} \mathrm{C}$ NMR $\left(101 \mathrm{MHz}, \mathrm{CDCl}_{3}\right) \delta 160.0,149.1,140.8,139.8,136.0,135.2,133.3$, $130.9,130.5,128.5,128.3,127.4,127.3,126.7,126.1,125.1,121.6,121.3,119.9,119.6,115.2$, 109.3, 45.4, 32.7, 31.3 (one Carbon signal not resolved). HR-ESI-MS $389.2016\left([\mathrm{M}+\mathrm{H}]^{+}\right.$, $\mathrm{C}_{28} \mathrm{H}_{25} \mathrm{~N}_{2}^{+}$; calc. for 389.2012). 


\section{5-Methoxy-1-methyl-3-(2-(pyridin-2-yl)phenyl)-1H-indole (56)}

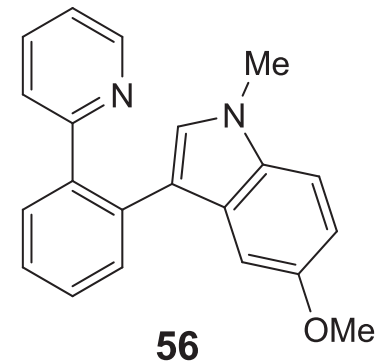

56

Starting from commercially available 2-phenylpyridine 49 (43.0 $\mu 1,0.300$ mmol) and with 1-(3-5-methoxy-1-methyl-1H-indole)-1H-1 $\lambda_{3} \quad$ benzo[b]iodo-3(2H)-one 27 (134 mg, $0.330 \mathrm{mmol}, 1.10$ equiv.) at $50{ }^{\circ} \mathrm{C}$, 5-methoxy-1-methyl-3-(2-(pyridin-2-yl)phenyl)-1H-indole 56 (84.0 mg, 0.267 mmol, $89 \%$ yield) was obtained as a yellow oil. Rf: 0.40 (Pentane:EtOAc 4:1). IR v 3051 (w), 2946 (w), 1585 (m), 1489 (s), 1463

(m), 1424 (m), 1295 (w), 1266 (s), 1228 (m), 1210 (s), 1181 (w), 1136 (m), 1088 (w), 1031 (m), $866(\mathrm{~m}) .{ }^{1} \mathbf{H}$ NMR $\left(400 \mathrm{MHz}, \mathrm{CDCl}_{3}\right) \delta 8.67(\mathrm{dd}, \mathrm{J}=4.9,0.9 \mathrm{~Hz}, 1 \mathrm{H}, \mathrm{ArH}), 7.76(\mathrm{dd}, \mathrm{J}=7.2,1.9$ $\mathrm{Hz}, 1 \mathrm{H}, \operatorname{Ar} H), 7.56(\mathrm{dd}, \mathrm{J}=7.2,1.9 \mathrm{~Hz}, 1 \mathrm{H}, \operatorname{Ar} H), 7.57-7.42(\mathrm{~m}, 2 \mathrm{H}, \operatorname{Ar} H), 7.26(\mathrm{td}, \mathrm{J}=7.7,1.9$ $\mathrm{Hz}, 1 \mathrm{H}, \mathrm{ArH}), 7.14$ (d, J = 8.9 Hz, 1H, ArH), 7.10 - 7.02 (m, 2H, ArH), 6.84 (s, 1H, NCHC), 6.79 $(\mathrm{dd}, \mathrm{J}=8.9,2.4 \mathrm{~Hz}, 1 \mathrm{H}, \mathrm{ArH}), 6.67(\mathrm{~d}, \mathrm{~J}=2.4 \mathrm{~Hz}, 1 \mathrm{H}, \mathrm{CCHCOMe}), 3.71$ (s, 3H, NCH $), 3.64$ (s, $\left.3 \mathrm{H}, \mathrm{OCH}_{3}\right) .{ }^{13} \mathbf{C} \mathbf{N M R}\left(101 \mathrm{MHz}, \mathrm{CDCl}_{3}\right) \delta 159.9,153.9,149.3,139.4,135.2,133.4,132.0,131.0$, $130.5,128.5,128.3,126.9,126.8,124.9,121.3,115.3,112.2,109.8,100.8,55.6,32.9$. HR-ESIMS $315.1493\left([\mathrm{M}+\mathrm{H}]^{+}, \mathrm{C}_{21} \mathrm{H}_{19} \mathrm{~N}_{2} \mathrm{O}^{+}\right.$; calc. for 315.1492).

\section{5-Fluoro-1-methyl-3-(2-(pyridin-2-yl)phenyl)-1 $H$-indole (57)}<smiles>Cn1cc(-c2ccccc2-c2ccccn2)c2cc(F)ccc21</smiles>

57

Starting from commercially available 2-phenylpyridine 49 (43.0 $\mu 1,0.300$ mmol) and with 1-(3-5-fluoro-1-methyl-1H-indole)-1H-1 $\lambda_{3}$-benzo[b]iodo$3(2 H)$-one 28 (130 mg, $0.330 \mathrm{mmol}, 1.10$ equiv.) at $50{ }^{\circ} \mathrm{C}, 5$-fluoro-1methyl-3-(2-(pyridin-2-yl)phenyl)-1H-indole 57 (66.0 mg, $0.218 \mathrm{mmol}$, $73 \%$ yield) was obtained as a yellow oil. Rf: 0.40 (Pentane:EtOAc 4:1). IR v $3063(\mathrm{w}), 2930(\mathrm{w}), 1624(\mathrm{~m}), 1585$ (m), $1488(\mathrm{~s}), 1464(\mathrm{~m}), 1425(\mathrm{~m})$, 1292 (w), 1192 (s), 1123 (m), 1060 (w), 873 (s). ${ }^{1} \mathbf{H}$ NMR (400 MHz, CDCl $) \delta 8.65$ (d, $J=4.9$ $\mathrm{Hz}, 1 \mathrm{H}, \operatorname{Ar} H), 7.71(\mathrm{~d}, J=7.2 \mathrm{~Hz}, 1 \mathrm{H}, \operatorname{Ar} H), 7.55(\mathrm{~d}, J=7.2 \mathrm{~Hz}, 1 \mathrm{H}, \operatorname{Ar} H), 7.51-7.38(\mathrm{~m}, 2 \mathrm{H})$, $7.33(\mathrm{t}, J=7.7 \mathrm{~Hz}, 1 \mathrm{H}, \operatorname{Ar} H), 7.17(\mathrm{dd}, J=9.0,4.3 \mathrm{~Hz}, 1 \mathrm{H}, \operatorname{Ar} H), 7.08$ (t, $J=6.3 \mathrm{~Hz}, 1 \mathrm{H}, \operatorname{Ar} H)$, $7.08-6.97(\mathrm{~m}, 2 \mathrm{H}, \mathrm{ArH}), 6.91(\mathrm{t}, J=9.0 \mathrm{~Hz}, 1 \mathrm{H}, \mathrm{ArH}), 6.77$ (s, 1H, NCHC), $3.70\left(\mathrm{~s}, 3 \mathrm{H}, \mathrm{NCH}_{3}\right)$. ${ }^{13} \mathrm{C}$ NMR $\left(101 \mathrm{MHz}, \mathrm{CDCl}_{3}\right) \delta 159.8,158.0(\mathrm{~d}, J=234.6 \mathrm{~Hz}), 149.3,139.7,135.2,133.4,132.9$, 130.8, 130.6, 129.7, 128.5, 127.3 (d, $J=9.9 \mathrm{~Hz}), 126.9,124.8,121.3,115.5$ (d, $J=4.9 \mathrm{~Hz}), 110.0$ $(\mathrm{d}, J=26.5 \mathrm{~Hz}), 109.7(\mathrm{~d}, J=9.7 \mathrm{~Hz}), 104.7(\mathrm{~d}, J=24.2 \mathrm{~Hz}), 33.0 .{ }^{19} \mathbf{F}$ NMR $\left(376 \mathrm{MHz}, \mathrm{CDCl}_{3}\right)$ $\delta$-125.1. HR-ESI-MS $303.1295\left([\mathrm{M}+\mathrm{H}]^{+}, \mathrm{C}_{20} \mathrm{H}_{16} \mathrm{FN}_{2}{ }^{+}\right.$; calc. for 303.1292). 


\section{5-Chloro-1-methyl-3-(2-(pyridin-2-yl)phenyl)-1H-indole (58)}<smiles>Cn1cc(-c2ccccc2-c2ccccn2)c2cc(Cl)ccc21</smiles>

58

Starting from commercially available 2-phenylpyridine 49 (43.0 $\mu 1,0.300$ mmol) and with 1-(3-5-chloro-1-methyl-1H-indole)- $1 H-1 \lambda_{3}$-benzo[b]iodo$3(2 \mathrm{H})$-one 29 (136 mg, $0.330 \mathrm{mmol}, 1.10$ equiv.) at $50^{\circ} \mathrm{C}$, 5-fluoro-1-methyl3-(2-(pyridin-2-yl)phenyl)-1H-indole 58 (77.0 mg, $0.242 \mathrm{mmol}, 81 \%$ yield) was obtained as a yellow oil. Rf: 0.36 (Pentane:EtOAc 4:1). IR $\vee 3055$ (w), $3014(\mathrm{w}), 2924$ (w), $1586(\mathrm{w}), 1543$ (w), 1477 (s), 1424 (m), $1374(\mathrm{w}), 1288$ (w), 1218 (w), 1152 (w), 1096 (w), 1058 (w), 953 (w). ${ }^{1} \mathbf{H}$ NMR (400 MHz, CDCl $) \delta 8.65$ (m, 1H, $\operatorname{Ar} H), 7.72(\mathrm{dd}, J=7.3,1.8 \mathrm{~Hz}, 1 \mathrm{H}, \operatorname{Ar} H), 7.55(\mathrm{~m}, 1 \mathrm{H}, \operatorname{Ar} H), 7.46$ (pd, $J=7.3,1.8 \mathrm{~Hz}, 2 \mathrm{H}, \operatorname{Ar} H)$, $7.38-7.31(\mathrm{~m}, 2 \mathrm{H}, \operatorname{Ar} H), 7.17(\mathrm{~d}, J=8.6 \mathrm{~Hz}, 1 \mathrm{H}, \operatorname{Ar} H), 7.14-7.07$ (m, 2H, ArH), $7.04(\mathrm{~m}, 1 \mathrm{H}$, $\mathrm{ArH}), 6.75$ (s, 1H, NCHC), 3.69 (s, 3H, NCH3). ${ }^{13} \mathbf{C}$ NMR (101 MHz, $\left.\mathrm{CDCl}_{3}\right) \delta 159.6,149.0$, 139.5, 135.6, 135.2, 132.7, 131.0, 130.6, 129.4, 128.7, 128.0, 127.1, 125.5, 124.9, 121.9, 121.4, 119.3, 115.2, 110.2, 33.0. HR-ESI-MS 319.1006 ([M+H] $]^{+}, \mathrm{C}_{20} \mathrm{H}_{16} \mathrm{ClN}_{2}{ }^{+}$; calc. for 319.0997).

\section{5-Iodo-1-methyl-3-(2-(pyridin-2-yl)phenyl)-1H-indole (59)}<smiles>Cn1cc(-c2ccccc2-c2ccccn2)c2cc(I)ccc21</smiles>

Starting from commercially available 2-phenylpyridine 49 (43.0 $\mu 1,0.300$ mmol) and with 1-(3-5-iodo-1-methyl-1H-indole)- $1 H-1 \lambda_{3}$-benzo[b]iodo$3(2 H)$-one 30 (166 mg, $0.330 \mathrm{mmol}, 1.10$ equiv.) at $50{ }^{\circ} \mathrm{C}$, 5-Iodo-1-methyl3-(2-(pyridin-2-yl)phenyl)- $1 H$-indole 59 (91.0 mg, $0.222 \mathrm{mmol}, 74 \%$ yield) was obtained as a yellow oil. Rf: 0.45 (Pentane:EtOAc 4:1). IR $v 3058(w)$, 2920 (w), 1606 (w), 1585 (m), 1474 (s), 1422 (m), 1371 (w), 1287 (w), 1266

(w), 1217 (w), 1148 (w), 1092 (w), 1024 (w), 943 (w), 874 (w). ${ }^{1} \mathbf{H}$ NMR (400 MHz, CDCl 3 ) $\delta$ $8.66(\mathrm{dd}, J=5.0,0.9 \mathrm{~Hz}, 1 \mathrm{H}, \operatorname{Ar} H), 7.71(\mathrm{~m}, 1 \mathrm{H}, \operatorname{Ar} H), 7.65(\mathrm{~d}, J=1.6 \mathrm{~Hz}, 1 \mathrm{H}, \operatorname{Ar} H), 7.53$ (m, $1 \mathrm{H}, \operatorname{Ar} H), 7.50-7.42(\mathrm{~m}, 2 \mathrm{H}, \operatorname{Ar} H), 7.39(\mathrm{dd}, J=8.5,1.6 \mathrm{~Hz}, 1 \mathrm{H}, \operatorname{Ar} H), 7.32(\mathrm{td}, J=7.7,1.9 \mathrm{~Hz}$, 1H, ArH), 7.08 (ddd, J=7.7, 5.0, 1.1 Hz, 1H, ArH), 7.07 - 6.97 (m, 2H, ArH), 6.70 (s, 1H, NCHC), $3.67\left(\mathrm{~s}, 3 \mathrm{H}, \mathrm{NCH}_{3}\right) .{ }^{13} \mathbf{C} \mathbf{N M R}\left(101 \mathrm{MHz}, \mathrm{CDCl}_{3}\right) \delta 159.7,149.3,139.8,135.7,135.2,132.5,130.9$, $130.5,129.8,129.2,128.7,128.7,128.5,127.0,124.7,121.4,114.9,111.1,83.2,32.9$. HR-ESIMS $411.0348\left([\mathrm{M}+\mathrm{H}]^{+}, \mathrm{C}_{20} \mathrm{H}_{16} \mathrm{IN}_{2}^{+}\right.$; calc. for 411.0353). 


\section{1-Methyl-3-(2-(pyridin-2-yl)phenyl)-5-(4,4,5,5-tetramethyl-1,3,2-dioxaborolan-2-yl)-1H-}

indole (60)

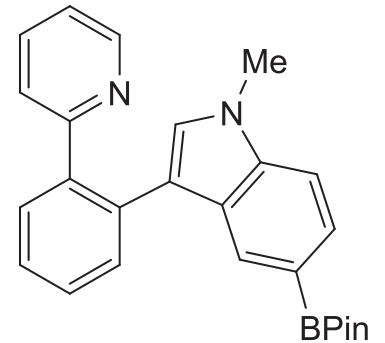

60

Starting from commercially available 2-phenylpyridine 49 (43.0 $\mu 1,0.300$ mmol) and with 1-(3-1-methyl-5-(4,4,5,5-tetramethyl-1,3,2-dioxaborolan2-yl)-1H-indole)-1H-1 $\lambda_{3}$-benzo[b]iodo-3(2H)-one 31 (166 mg, 0.330 mmol, 1.10 equiv.) at $50{ }^{\circ} \mathrm{C}, 1-$ Methyl-3-(2-(pyridin-2-yl)phenyl)-5(4,4,5,5-tetramethyl-1,3,2-dioxaborolan-2-yl)-1H-indole $\mathbf{6 0}(73.0 \mathrm{mg}$, $0.178 \mathrm{mmol}, 59 \%$ yield) was obtained as a yellow oil. Rf: 0.30 (Pentane:EtOAc 4:1). IR v 3063 (w), 2978 (w), 2940 (w), 2245 (w), 2214 (w), 1608 (m), 1605 (m), 1568 (w), 1463 (m), 1438 (m), 1383 (s), 1349 (s), 1311 (s), 1273 (m), 1142 (s), 1097 (m), 967 (m), 910 (s), 866 (m). ${ }^{1} \mathbf{H}$ NMR (400 MHz, $\left.\mathrm{CDCl}_{3}\right) \delta 8.64(\mathrm{~d}, J=5.0 \mathrm{~Hz}, 1 \mathrm{H}, \mathrm{Ar} H), 8.00(\mathrm{~s}, 1 \mathrm{H}, \mathrm{Ar} H)$, $7.71(\mathrm{~d}, J=7.5 \mathrm{~Hz}, 1 \mathrm{H}, \operatorname{Ar} H), 7.64(\mathrm{dd}, J=8.3,1.1 \mathrm{~Hz}, 1 \mathrm{H}, \operatorname{Ar} H), 7.61$ (m, 1H, ArH), $7.46(\mathrm{td}, J$ $=7.4,1.7 \mathrm{~Hz}, 1 \mathrm{H}, \operatorname{Ar} H), 7.41(\mathrm{td}, J=7.4,1.6 \mathrm{~Hz}, 1 \mathrm{H}, \operatorname{Ar} H), 7.29-7.26(\mathrm{~m}, 2 \mathrm{H}, \operatorname{Ar} H), 7.00$ (ddd, $J=7.5,4.9,1.2 \mathrm{~Hz}, 1 \mathrm{H}, \operatorname{Ar} H), 6.95(\mathrm{dt}, J=7.9,1.0 \mathrm{~Hz}, 1 \mathrm{H}, \operatorname{Ar} H), 6.62(\mathrm{~s}, 1 \mathrm{H}, \operatorname{Ar} H), 3.68(\mathrm{~s}, 3 \mathrm{H}$, $\left.\mathrm{NCH}_{3}\right), 1.34$ (s, 12H, BPin). ${ }^{13} \mathbf{C}$ NMR $\left(101 \mathrm{MHz}, \mathrm{CDCl}_{3}\right) \delta 159.9,149.1,140.0,138.6,135.0$, $133.1,131.2,130.3,128.4,128.2,127.7,127.7,126.9,126.7,124.9,121.1,116.0,108.5,83.3$, 32.6, 24.8 (one aromatic Carbon signal not resolved). HR-ESI-MS $411.2248\left([\mathrm{M}+\mathrm{H}]^{+}\right.$, $\mathrm{C}_{26} \mathrm{H}_{28} \mathrm{BN}_{2} \mathrm{O}_{2}{ }^{+}$; calc. for 411.2238).

\section{2-(2-(1-methyl-1H-pyrrol-2-yl)phenyl)pyridine (61)}

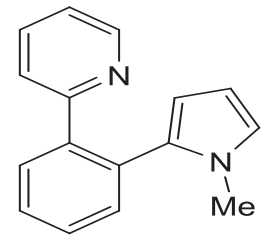

61

Starting from commercially available 2-phenylpyridine 49 (43.0 $\mu 1,0.300 \mathrm{mmol}$, 1.00 equiv.) and with 1-(2-1-methyl- $1 H$-pyrrole)-1H-1 $\lambda_{3}$-benzo[b]iodo-3(2H)one 35a (108 mg, $0.330 \mathrm{mmol}, 1.10$ equiv.) at $80^{\circ} \mathrm{C}, 2-(2-(1-$ methyl- $1 H$-pyrrol2-yl)phenyl)pyridine 61 (60.0 mg, $0.256 \mathrm{mmol}, 85 \%$ yield) was obtained as a pale yellow oil. Rf: 0.42 (Pentane:EtOAc 4:1). IR v 3098 (w), 3059 (w), 2926 (m), 2854 (w), 1707 (w), 1585 (s), 1473 (s), 1429 (s), 1310 (s), 1239 (w), 1090 (m), $1056(\mathrm{~m}), 1024$ (m). ${ }^{1} \mathbf{H}$ NMR (400 MHz, $\left.\mathrm{CDCl}_{3}\right) \delta 8.67(\mathrm{~m}, 1 \mathrm{H}, \mathrm{Ar} H), 7.86(\mathrm{~d}, J=7.5 \mathrm{~Hz}$, $1 \mathrm{H}, \operatorname{Ar} H), 7.55-7.40(\mathrm{~m}, 4 \mathrm{H}, \operatorname{Ar} H), 7.14$ (ddd, $J=7.5,4.9,1.1 \mathrm{~Hz}, 1 \mathrm{H}, \operatorname{Ar} H), 6.80$ (m, 1H, ArH), $6.51(\mathrm{t}, J=2.3 \mathrm{~Hz}, 1 \mathrm{H}, \mathrm{Ar} H), 6.18-6.15(\mathrm{~m}, 2 \mathrm{H}, \mathrm{ArH}), 2.90\left(\mathrm{~s}, 3 \mathrm{H}, \mathrm{NCH}_{3}\right) .{ }^{13} \mathbf{C}$ NMR $(101 \mathrm{MHz}$, $\left.\mathrm{CDCl}_{3}\right) \delta 158.6,149.5,140.0,135.7,133.2,131.8,131.5,130.1,128.5,128.4,123.7,122.2,121.5$, 109.2, 107.7, 33.8. HR-ESI-MS 235.1233 ([M+H] $]^{+}, \mathrm{C}_{16} \mathrm{H}_{15} \mathrm{~N}_{2}{ }^{+}$; calc. for 235.1230). 


\section{2-(2-(1-Methyl-1H-pyrrol-3-yl)phenyl)pyridine (62)}

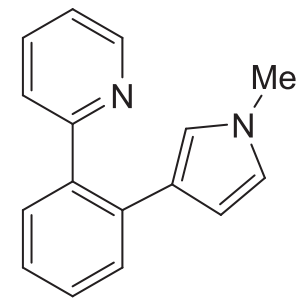

62

Starting from commercially available 2-phenylpyridine $49(43.0 \mu 1,0.300$ mmol, 1.00 equiv.) and with 1-(3-1-methyl- $1 H$-pyrrole)- $1 H-1 \lambda_{3}$-benzo[b]iodo$3(2 \mathrm{H})$-one $35 \mathbf{b}$ (108 $\mathrm{mg}, 0.330 \mathrm{mmol}, 1.10$ equiv.) at $80^{\circ} \mathrm{C}, 2-(2-(1-M e t h y l-$ $1 H$-pyrrol-3-yl)phenyl)pyridine $62(60.0 \mathrm{mg}, 0.256 \mathrm{mmol}, 85 \%$ yield $)$ was obtained as a yellow oil. Rf: 0.38 (Pentane:EtOAc 4:1). IR $v 3056$ (w), 3007 (w), 2943 (w), 1586 (s), 1551 (m), 1508 (m), 1463 (s), 1424 (s), 1361 (m), 1260 (w), 1202 (s), 1150 (w), 1087 (w), 1024 (w), 990 (w), 926 (w). ${ }^{1} \mathbf{H}$ NMR (400 MHz, $\mathrm{CDCl}_{3}$ ) $\delta 8.67$ (d, $J=5.0 \mathrm{~Hz}, 1 \mathrm{H}, \operatorname{Ar} H), 7.57-7.46$ (m, 3H, $\operatorname{Ar} H), 7.37$ (t, $J=7.5 \mathrm{~Hz}, 1 \mathrm{H}, \operatorname{Ar} H$ ), 7.31 (d, $J=7.5$ $\mathrm{Hz}, 1 \mathrm{H}, \operatorname{Ar} H), 7.22(\mathrm{~d}, J=7.9 \mathrm{~Hz}, 1 \mathrm{H}, \operatorname{Ar} H), 7.18(\mathrm{dd}, J=7.4,5.1 \mathrm{~Hz}, 1 \mathrm{H}, \operatorname{Ar} H), 6.43(\mathrm{t}, J=2.5$ $\mathrm{Hz}, 1 \mathrm{H}, \mathrm{Ar} H), 6.30(\mathrm{~d}, J=1.6 \mathrm{~Hz}, 1 \mathrm{H}, \mathrm{Ar} H), 5.80(\mathrm{~d}, J=1.6 \mathrm{~Hz}, 1 \mathrm{H}, \mathrm{Ar} H), 3.54\left(\mathrm{~s}, 3 \mathrm{H}, \mathrm{NCH}_{3}\right)$. ${ }^{13} \mathrm{C}$ NMR $\left(101 \mathrm{MHz}, \mathrm{CDCl}_{3}\right) \delta 160.6,149.1,138.7,135.2,134.8,130.2,129.3,128.3,125.8$, 125.2, 123.8, 121.5, 121.3, 120.6, 109.2, 36.1. HR-ESI-MS $235.1230\left([\mathrm{M}+\mathrm{H}]^{+}, \mathrm{C}_{16} \mathrm{H}_{15} \mathrm{~N}_{2}{ }^{+}\right.$; calc. for 235.1230).

\section{2-(2-(1-benzyl-1H-pyrrol-2-yl)phenyl)pyridine (63)}

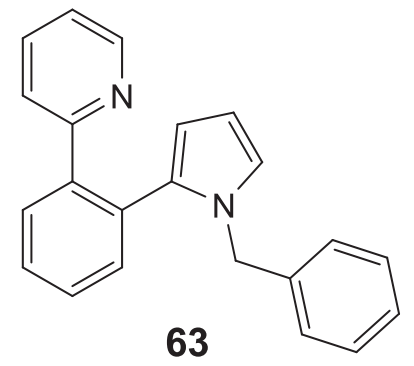

Starting from commercially available 2-phenylpyridine 49 (43.0 $\mu$, 0.300 mmol, 1.00 equiv.) and with 1-(2-1-benzyl-1H-pyrrole)- $1 H-1 \lambda_{3}-$ benzo[b]iodo-3(2H)-one 36a (133 $\mathrm{mg}, 0.330 \mathrm{mmol}, 1.10$ equiv.) at 80 ${ }^{\circ} \mathrm{C}$, 2-(2-(1-benzyl-1H-pyrrol-2-yl)phenyl)pyridine 63 (63.0 mg, 0.203 mmol, 68\% yield) as an pale yellow oil. Rf: 0.32 (Pentane:EtOAc 4:1). IR $v 3062$ (m), 3029 (w), 2925 (w), 1585 (s), 1471 (s), 1427 (s), 1311 (m), 1298 (m), 1236 (m), 1153 (w), 1076 (m), 1024 (m), 989 (w). ${ }^{1} \mathbf{H}$ NMR (400 MHz, CDCl 3 ) $\delta$ $8.68(\mathrm{~d}, J=4.9 \mathrm{~Hz}, 1 \mathrm{H}, \operatorname{Ar} H), 7.85(\mathrm{~m}, 1 \mathrm{H}, \operatorname{Ar} H), 7.53-7.42$ (m, 2H, $\operatorname{Ar} H), 7.42-7.33$ (m, 2H, $\operatorname{Ar} H), 7.17-7.13(\mathrm{~m}, 4 \mathrm{H}, \mathrm{Ar} H), 6.83(\mathrm{~d}, J=7.9 \mathrm{~Hz}, 1 \mathrm{H}, \mathrm{Ar} H), 6.72(\mathrm{dd}, J=6.6,2.9 \mathrm{~Hz}, 2 \mathrm{H}, \operatorname{Ar} H)$, $6.52(\mathrm{~m}, 1 \mathrm{H}, \mathrm{Ar} H), 6.24-6.13(\mathrm{~m}, 2 \mathrm{H}, \mathrm{ArH}), 4.45$ (s, 2H, NCH $\left.\mathrm{H}_{2} \mathrm{Ph}\right) .{ }^{13} \mathbf{C} \mathbf{N M R}\left(101 \mathrm{MHz}, \mathrm{CDCl}_{3}\right)$ $\delta 158.7,149.5,140.2,138.1,135.8,133.2,132.1,131.7,130.3,128.6,128.6,128.4,127.3,127.2$, 124.2, 121.7, 110.1, 108.3, 50.6. (2 Cs overlapping at 121.7, shown by HSQC). HR-ESI-MS $311.1542\left([\mathrm{M}+\mathrm{H}]^{+}, \mathrm{C}_{22} \mathrm{H}_{19} \mathrm{~N}_{2}{ }^{+}\right.$; calc. for 311.1543$)$. 


\section{2-(2-(1-Benzyl-1H-pyrrol-3-yl)phenyl)pyridine (64)}

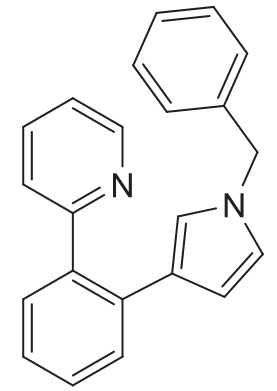

64

Starting from commercially available 2-phenylpyridine 49 (43.0 $\mu 1,0.300 \mathrm{mmol}$, 1.00 equiv.) and with 1-(3-1-benzyl-1H-pyrrole)-1H-1 $\lambda_{3}$-benzo[b]iodo-3(2H)one $36 \mathbf{b}$ (133 mg, $0.330 \mathrm{mmol}, 1.10$ equiv.) at $80{ }^{\circ} \mathrm{C}$, 2-(2-(1-Benzyl-1H-pyrrol3-yl)phenyl)pyridine 64 (54.0 $\mathrm{mg}, 0.174 \mathrm{mmol}, 58 \%$ yield) was obtained as an pale yellow oil. Rf: 0.30 (Pentane:EtOAc 4:1). IR $v 3062$ (m), 2925 (m), 2854 (w), 1708 (m), 1586 (s), 1562 (m), 1498 (s), 1463 (s), 1425 (s), 1355 (m), 1190 (m), $1082(\mathrm{~m}), 1025$ (m). ${ }^{1} \mathbf{H}$ NMR $\left(400 \mathrm{MHz}, \mathrm{CDCl}_{3}\right) \delta 8.62(\mathrm{~m}, 1 \mathrm{H}, \mathrm{ArH}), 7.51$ - 7.45 (m, 3H, ArH), 7.38 (td, $J=7.5,1.6 \mathrm{~Hz}, 1 \mathrm{H}, \operatorname{Ar} H), 7.34-7.26(\mathrm{~m}, 4 \mathrm{H}, \operatorname{Ar} H), 7.20(\mathrm{~d}, J=$ $7.9 \mathrm{~Hz}, 1 \mathrm{H}, \operatorname{Ar} H) 7.13$ (ddd, $J=7.4,4.9,1.2 \mathrm{~Hz}, 1 \mathrm{H}, \operatorname{Ar} H), 7.03-6.97$ (m, 2H, ArH), 6.54 (t, $J=$ $2.5 \mathrm{~Hz}, 1 \mathrm{H}, \operatorname{Ar} H), 6.25$ (t, $J=1.8 \mathrm{~Hz}, 1 \mathrm{H}, \operatorname{Ar} H), 5.99$ (dd, $J=2.5,1.8 \mathrm{~Hz}, 1 \mathrm{H}, \operatorname{Ar} H), 4.92$ (s, 2H, $\left.\mathrm{NCH}_{2} \mathrm{Ph}\right) .{ }^{13} \mathbf{C}$ NMR $\left(101 \mathrm{MHz}, \mathrm{CDCl}_{3}\right) \delta 160.5,149.1,138.8,137.9,135.2,134.8,130.1,129.4$, 128.6, 128.3, 127.6, 126.9, 126.0, 125.2, 123.9, 121.3, 121.0, 120.4, 109.4, 53.3. HR-ESI-MS $311.1545\left([\mathrm{M}+\mathrm{H}]^{+}, \mathrm{C}_{22} \mathrm{H}_{19} \mathrm{~N}_{2}{ }^{+}\right.$; calc. for 311.1543$)$.

\section{2-(2-(1H-Pyrrol-3-yl)phenyl)pyridine (65)}<smiles>c1ccc(-c2ccccc2-c2cc[nH]c2)nc1</smiles>

65

Starting from commercially available 2-phenylpyridine 49 (43.0 $\mu 1,0.300 \mathrm{mmol}$,

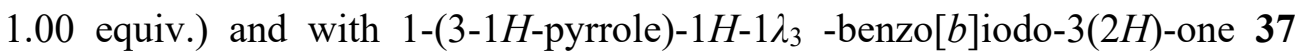
(103 mg, $0.330 \mathrm{mmol}, 1.10$ equiv.) in a mixture of 1,2-DCE:MeOH $(2: 1,0.1 \mathrm{M})$ at $50{ }^{\circ} \mathrm{C}, 2-(2-(1 H$-pyrrol-3-yl)phenyl)pyridine 65 (52.0 mg, $0.236 \mathrm{mmol}, 79 \%$ yield) was obtained as a light brown foam. Rf: 0.42 (Pentane:EtOAc 4:1). IR v 3191 (m), 3054 (m), 2928 (w), 1601 (s), 1589 (s), 1562 (m), 1505 (m), 1464 (s), 1426 (s), 1267 (w), 1152 (w), 1078 (w), 1028 (m), 996 (w), 917 (w). ${ }^{\mathbf{1}} \mathbf{H}$ NMR (400 MHz, CDCl ${ }_{3}$ ) $\delta 8.67(\mathrm{~m}, 1 \mathrm{H}, \operatorname{Ar} H), 8.29(\mathrm{~m}, 1 \mathrm{H}, \mathrm{NH}), 7.57-7.47$ (m, 3H, $\operatorname{Ar} H), 7.40(\mathrm{dd}, J=8.2,6.8 \mathrm{~Hz}, 1 \mathrm{H}$, $\operatorname{Ar} H), 7.32(\mathrm{t}, J=7.3 \mathrm{~Hz}, 1 \mathrm{H}, \operatorname{Ar} H), 7.23-7.15(\mathrm{~m}, 2 \mathrm{H}, \operatorname{Ar} H), 6.62(\mathrm{~d}, J=2.6 \mathrm{~Hz}, 1 \mathrm{H}, \operatorname{Ar} H), 6.43$ $(\mathrm{d}, J=2.6 \mathrm{~Hz}, 1 \mathrm{H}, \operatorname{Ar} H), 5.95(\mathrm{dd}, J=2.9,1.6 \mathrm{~Hz}, 1 \mathrm{H}, \mathrm{Ar} H) .{ }^{13} \mathbf{C} \mathbf{N M R}\left(101 \mathrm{MHz}, \mathrm{CDCl}_{3}\right) \delta$ 160.6, 149.2, 139.0, 135.2, 134.7, 130.2, 129.6, 128.4, 126.1, 125.2, 123.8, 121.4, 117.6, 116.8, 109.3. HR-ESI-MS 221.1077 ([M+H $]^{+}, \mathrm{C}_{15} \mathrm{H}_{13} \mathrm{~N}_{2}{ }^{+}$; calc. for 221.1073).

\section{3-(5-Methoxy-2-(pyridin-2-yl)phenyl)-1-methyl-1H-indole (66)}




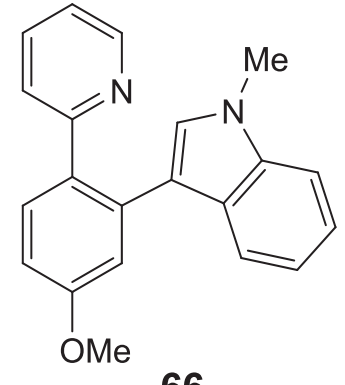

66

Starting from commercially available 2-(4-methoxyphenyl)pyridine (55.6 mg, $0.300 \mathrm{mmol})$ and with 1-(3-1-methyl- $1 H$-indole)- $1 H-1 \lambda_{3}$-benzo[b]iodo3(2H)-one 21 (124 mg, $0.330 \mathrm{mmol}, 1.10$ equiv.) at $50{ }^{\circ} \mathrm{C}, 3-(5-m e t h o x y-2-$ (pyridin-2-yl)phenyl)-1-methyl-1H-indole 66 (83.0 mg, $0.264 \mathrm{mmol}, 88 \%$ yield) was obtained as a yellow oil. Rf: 0.38 (Pentane:EtOAc 4:1). IR $v 3049$ (w), 2933 (w), 2834 (w), 1602 (s), 1568 (m), 1463 (s), 1426 (m), 1278 (s), 1232 (s), 1210 (m), 1062 (m), 1017 (m), 844 (w). ${ }^{1}$ H NMR (400 MHz, $\left.\mathrm{CDCl}_{3}\right) \delta 8.64(\mathrm{~d}, J=5.0 \mathrm{~Hz}, 1 \mathrm{H}, \mathrm{Ar} H), 7.70(\mathrm{~d}, J=8.5 \mathrm{~Hz}, 1 \mathrm{H}, \mathrm{Ar} H), 7.45(\mathrm{~d}, J=8.0 \mathrm{~Hz}, 1 \mathrm{H}$, $\operatorname{Ar} H), 7.31-7.23(\mathrm{~m}, 2 \mathrm{H}, \operatorname{Ar} H), 7.20(\mathrm{t}, J=7.6 \mathrm{~Hz}, 1 \mathrm{H}, \operatorname{Ar} H), 7.13(\mathrm{~d}, J=2.7 \mathrm{~Hz}, 1 \mathrm{H}, \operatorname{Ar} H), 7.06$ - $6.95(\mathrm{~m}, 4 \mathrm{H}, \mathrm{ArH}), 6.73$ (s, 1H, $\left.\mathrm{CH}_{3} \mathrm{NCHC}\right), 3.89$ (s, 3H, NCH $), 3.71\left(\mathrm{~s}, 3 \mathrm{H}, \mathrm{OCH}_{3}\right) .{ }^{13} \mathbf{C} \mathbf{~ N M R}$ $\left(101 \mathrm{MHz}, \mathrm{CDCl}_{3}\right) \delta 159.6,159.4,148.9,136.7,135.2,134.6,132.3,131.9,128.2,126.8,125.0$, 121.6, 120.8, 119.9, 119.5, 115.9, 115.3, 112.6, 109.1, 55.3, 32.8. HR-ESI-MS 315.1494 ([M+H]+, $\mathrm{C}_{21} \mathrm{H}_{19} \mathrm{~N}_{2} \mathrm{O}^{+}$; calc. for 315.1492).

\section{3-(5-Chloro-2-(pyridin-2-yl)phenyl)-1-methyl-1H-indole (67)}

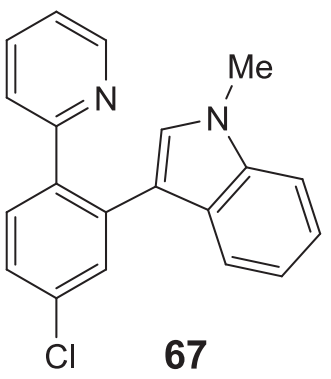

Starting from commercially available 2-(4-chlorophenyl)pyridine $(57.0 \mathrm{mg}$, $0.300 \mathrm{mmol})$ and with 1-(3-1-methyl-1H-indole)- $1 H-1 \lambda_{3}$-benzo[b]iodo3(2H)-one 21 (124 mg, $0.330 \mathrm{mmol}, 1.10$ equiv.) at $50{ }^{\circ} \mathrm{C}, 3$-(5-chloro-2(pyridin-2-yl)phenyl)-1-methyl-1H-indole 67 (81.2 mg, 0.255 mmol, 85\% yield) was obtained as a yellow oil. Rf: 0.40 (Pentane:EtOAc 4:1). IR $v 3055$ (w), $2926(\mathrm{w}), 1595$ (s), $1566(\mathrm{~m}), 1476(\mathrm{~m}), 1461(\mathrm{~s}), 1427(\mathrm{w}), 1329(\mathrm{~m})$, 1219 (w), 1163 (w), 1100 (m), 1026 (w), 913 (w), 830 (w). ${ }^{1} \mathbf{H}$ NMR (400 MHz, CDCl 3 ) $\delta 8.65$ (m, 1H, ArH), 7.68 (d, $J=8.3 \mathrm{~Hz}, 1 \mathrm{H}, \operatorname{Ar} H), 7.59$ (d, $J=2.2 \mathrm{~Hz}, 1 \mathrm{H}, \operatorname{Ar} H), 7.40(\mathrm{dd}, J=8.3,2.2$ $\mathrm{Hz}, 1 \mathrm{H}, \operatorname{Ar} H), 7.37$ (dd, $J=8.0,1.0 \mathrm{~Hz}, 1 \mathrm{H}, \operatorname{Ar} H), 7.30(\mathrm{dd}, J=7.7,1.7 \mathrm{~Hz}, 1 \mathrm{H}, \operatorname{Ar} H), 7.27(\mathrm{~m}$, 1H, $\operatorname{Ar} H), 7.19$ (ddd, $J=8.2,7.0,1.1 \mathrm{~Hz}, 1 \mathrm{H}, \mathrm{Ar} H), 7.08$ (ddd, $J=7.5,4.9,1.1 \mathrm{~Hz}, 1 \mathrm{H}, \operatorname{Ar} H), 7.04$ - $6.99(\mathrm{~m}, 2 \mathrm{H}, \mathrm{ArH}), 6.75(\mathrm{~s}, 1 \mathrm{H}, \mathrm{NCHC}), 3.71\left(\mathrm{~s}, 3 \mathrm{H}, \mathrm{NCH}_{3}\right) .{ }^{13} \mathbf{C} \mathbf{N M R}\left(101 \mathrm{MHz}, \mathrm{CDCl}_{3}\right) \delta$ $158.7,149.2$, 137.9, 136.8, 135.4, 135.1, 134.3, 132.0, 130.7, 128.4, 126.7, 126.6, 124.9, 121.8, 121.5, 119.8, 119.7, 114.3, 109.2, 32.8. HR-ESI-MS $319.0999\left([\mathrm{M}+\mathrm{H}]^{+}, \mathrm{C}_{20} \mathrm{H}_{16} \mathrm{ClN}_{2}{ }^{+}\right.$; calc. for 319.0997).

\section{3-(5-Bromo-2-(pyridin-2-yl)phenyl)-1-methyl-1 $H$-indole (68)}




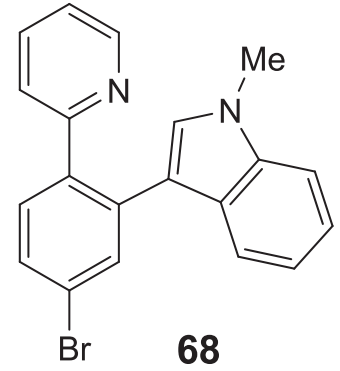

Starting from commercially available 2-(4-bromophenyl)pyridine (70.2 mg, $0.300 \mathrm{mmol})$ and with 1-(3-1-methyl-1H-indole)- $1 H-1 \lambda_{3}$-benzo[b]iodo3(2H)-one 21 (124 mg, $0.330 \mathrm{mmol}, 1.10$ equiv.) at $50{ }^{\circ} \mathrm{C}, 3-(5$-methoxy-2(pyridin-2-yl)phenyl)-1-methyl-1H-indole 68 (91.0 mg, $0.251 \mathrm{mmol}, 84 \%$ yield) was obtained as a yellow oil. Rf: 0.40 (Pentane:EtOAc 4:1). IR $\vee 2956$ (w), $2929(\mathrm{w}), 2851(\mathrm{w}), 1678(\mathrm{w}), 1592(\mathrm{~m}), 1510(\mathrm{~m}), 1453(\mathrm{~m}), 1453(\mathrm{~m})$, 1434 (s), 1399 (s), 1364 (s), 1264 (m), 1108 (m), 1031 (m), 956 (m). ${ }^{1} \mathbf{H}$ NMR (400 MHz, CDCl $)$ $\delta 8.66(\mathrm{~m}, 1 \mathrm{H}, \operatorname{Ar} H), 7.75(\mathrm{~d}, \mathrm{~J}=2.0 \mathrm{~Hz}, 1 \mathrm{H}, \operatorname{Ar} H), 7.63(\mathrm{~d}, \mathrm{~J}=8.3 \mathrm{~Hz}, 1 \mathrm{H}, \operatorname{Ar} H), 7.56(\mathrm{dd}, \mathrm{J}=$ 8.3, $2.0 \mathrm{~Hz}, 1 \mathrm{H}, \operatorname{Ar} H), 7.36$ - 7.31 (m, 2H, $\operatorname{Ar} H), 7.28$ (dt, J=8.2, $0.9 \mathrm{~Hz}, 1 \mathrm{H}, \operatorname{Ar} H), 7.19$ (ddd, J $=8.2,6.9,0.9 \mathrm{~Hz}, 1 \mathrm{H}, \operatorname{Ar} H), 7.11(\mathrm{t}, \mathrm{J}=6.3 \mathrm{~Hz}, 1 \mathrm{H}, \operatorname{Ar} H), 7.04(\mathrm{~d}, \mathrm{~J}=8.0 \mathrm{~Hz}, 1 \mathrm{H}, \operatorname{Ar} H), 6.99(\mathrm{~m}$, 1H, $\mathrm{ArH}), 6.77(\mathrm{~s}, 1 \mathrm{H}, \mathrm{NCHC}), 3.72(\mathrm{~s}, 3 \mathrm{H}, \mathrm{NCH}) .{ }^{13} \mathbf{C} \mathbf{~ N M R}\left(101 \mathrm{MHz}, \mathrm{CDCl}_{3}\right) \delta 158.7,149.3$, $138.5,136.7,135.4,135.2,133.5,132.1,129.6,128.3,126.5,124.7,122.4,121.8,121.5,119.7$, 119.6, 114.2, 109.2, 32.7. HR-ESI-MS $363.0490\left([\mathrm{M}+\mathrm{H}]^{+}, \mathrm{C}_{20} \mathrm{H}_{16}{ }^{79} \mathrm{BrN}_{2}{ }^{+}\right.$; calc. for 363.0491).

\section{3-(1-Methyl-1H-indol-3-yl)-4-(pyridin-2-yl)benzonitrile (69)}

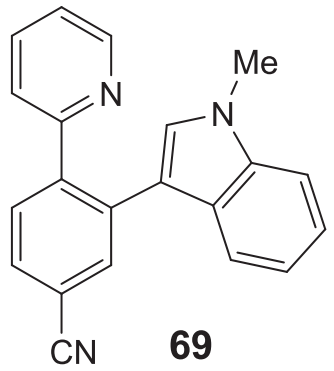

Starting from commercially available 4-(pyridin-2-yl)benzonitrile $(54.0 \mathrm{mg}$, $0.300 \mathrm{mmol})$ and with 1-(3-1-methyl- $1 H$-indole)- $1 H-1 \lambda_{3}$-benzo[b]iodo$3(2 H)$-one 21 (124 mg, $0.330 \mathrm{mmol}, 1.10$ equiv.) at $80{ }^{\circ} \mathrm{C}, 3-(1-$ methyl- $1 H$ indol-3-yl)-4-(pyridin-2-yl)benzonitrile $69(72.0 \mathrm{mg}, 0.233 \mathrm{mmol}, 78 \%$ yield) was obtained as a yellow oil. Rf: 0.35 (Pentane:EtOAc 4:1). IR $v 3053$ (w), 2932 (w), 2230 (m), 1587 (m), 1558 (w), 1475 (m), 1463 (m), $1330(\mathrm{w})$, 1266 (s), 1224 (w), 1160 (w), 1091 (w), 1026 (w), 902 (w), 839 (m). ${ }^{1} \mathbf{H}$ NMR (400 MHz, CDCl $)$ $\delta 8.70(\mathrm{~m}, 1 \mathrm{H}, \operatorname{Ar} H), 7.88(\mathrm{~d}, J=1.7 \mathrm{~Hz}, 1 \mathrm{H}, \operatorname{Ar} H), 7.83(\mathrm{~d}, J=8.0 \mathrm{~Hz}, 1 \mathrm{H}, \operatorname{Ar} H), 7.69$ (dd, $J=$ 8.0, $1.7 \mathrm{~Hz}, 1 \mathrm{H}, \mathrm{Ar} H), 7.36-7.27$ (m, 3H, ArH), 7.21 (ddd, $J=8.3,7.0,1.1 \mathrm{~Hz}, 1 \mathrm{H}, \operatorname{Ar} H), 7.13$ (ddd, $J=7.5,4.9,1.2 \mathrm{~Hz}, 1 \mathrm{H}, \operatorname{Ar} H), 7.05$ (d, $J=8.0 \mathrm{~Hz}, 1 \mathrm{H}, \operatorname{Ar} H$ ), 7.02 (ddd, $J=8.0,7.0,1.1 \mathrm{~Hz}$, 1H, $\mathrm{ArH}), 6.77$ (s, 1H, NCHC), 3.73 (s, 3H, NCH3). $\left.{ }^{13} \mathbf{C ~ N M R ~ ( 1 0 1 ~ M H z , ~} \mathrm{CDCl}_{3}\right) \delta 157.9,149.6$, $143.6,136.7,135.6,134.8,134.5,131.5,129.8,128.4,126.3,124.7,122.2,122.0,120.1,119.3$, 118.9, 113.3, 112.1, 109.4, 32.9. HR-ESI-MS $310.1344\left([\mathrm{M}+\mathrm{H}]^{+}, \mathrm{C}_{21} \mathrm{H}_{16} \mathrm{~N}_{3}{ }^{+}\right.$; calc. for 310.1339).

\section{Methyl 3-(1-methyl-1H-indol-3-yl)-4-(pyridin-2-yl)benzoate (70)}




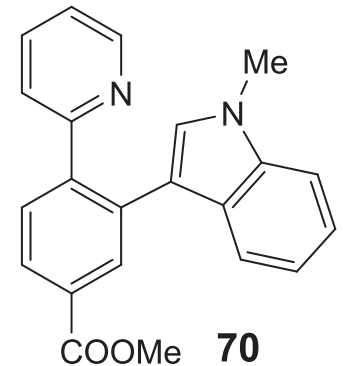

Starting from methyl 4-(pyridin-2-yl)benzoate $121(64.0 \mathrm{mg}, 0.300 \mathrm{mmol})$ and with 1-(3-1-methyl-1H-indole)-1H-1 $\lambda_{3}$-benzo[b]iodo-3(2H)-one 21 (124 mg, $0.330 \mathrm{mmol}, 1.10$ equiv.) at $50^{\circ} \mathrm{C}$, methyl 3-(1-methyl- $1 H$-indol3-yl)-4-(pyridin-2-yl)benzoate 70 (94.0 $\mathrm{mg}, 0.275 \mathrm{mmol}, 92 \%$ yield) was obtained as an orange oil. Rf: 0.33 (Pentane:EtOAc 4:1). ${ }^{1}$ H NMR (400 $\left.\mathrm{MHz}, \mathrm{CDCl}_{3}\right) \delta 8.61(\mathrm{dd}, J=5.1,1.6 \mathrm{~Hz}, 1 \mathrm{H}, \mathrm{Ar} H), 8.20(\mathrm{~d}, J=1.7 \mathrm{~Hz}, 1 \mathrm{H}$, $\operatorname{Ar} H), 7.99(\mathrm{dd}, J=8.1,1.8 \mathrm{~Hz}, 1 \mathrm{H}, \operatorname{Ar} H), 7.72(\mathrm{~d}, J=8.1 \mathrm{~Hz}, 1 \mathrm{H}, \operatorname{Ar} H), 7.26(\mathrm{~d}, J=8.0 \mathrm{~Hz}, 1 \mathrm{H}$, $\operatorname{ArH}), 7.24-7.16(\mathrm{~m}, 2 \mathrm{H}, \operatorname{Ar} H), 7.09(\mathrm{t}, J=7.6 \mathrm{~Hz}, 1 \mathrm{H}, \operatorname{Ar} H), 7.03-6.96(\mathrm{~m}, 2 \mathrm{H}, \operatorname{Ar} H), 6.90(\mathrm{t}$, $J=7.5 \mathrm{~Hz}, 1 \mathrm{H}, \mathrm{ArH}), 6.71(\mathrm{~s}, 1 \mathrm{H}, \mathrm{NCHC}), 3.85(\mathrm{~s}, 3 \mathrm{H}, \mathrm{COOMe}), 3.61(\mathrm{~s}, 3 \mathrm{H}, \mathrm{NCH}) .{ }^{13} \mathbf{C} \mathbf{~ N M R}$ $\left(101 \mathrm{MHz}, \mathrm{CDCl}_{3}\right) \delta 167.0,158.8,149.4,143.8,136.8,135.3,133.7,132.3,130.7,129.9,128.3$, 127.6, 126.7, 124.7, 121.8, 121.7, 119.7, 114.7, 109.1, 52.1, 32.8 (two aromatic Carbon signals overlapping at 119.7). IR v 3052 (w), 2950 (w), 2252 (w), 2218 (w), 1718 (s), 1587 (m), $1436(\mathrm{~m})$, 1365 (m), 1330 (m), 1286 (s), 1251 (s), 1162 (m), 1113 (m), 994 (w), 911 (s). HR-ESI-MS $343.1438\left([\mathrm{M}+\mathrm{H}]^{+}, \mathrm{C}_{22} \mathrm{H}_{19} \mathrm{~N}_{2} \mathrm{O}_{2}{ }^{+}\right.$; calc. for 343.1441).

\section{1-Methyl-3-(2-(pyrimidin-2-yl)phenyl)-1H-indole (71)}

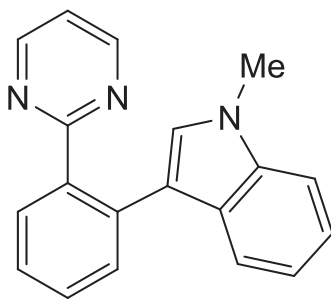

71

Starting from commercially available 2-phenylpyrimidine $(47.0 \mathrm{mg}, 0.300$ mmol) and with 1-(3-1-methyl-1H-indole)-1H-1 $\lambda_{3}$-benzo[b]iodo-3(2H)one 21 (124 mg, $0.330 \mathrm{mmol}, 1.10$ equiv.) at $80{ }^{\circ} \mathrm{C}, 1$-methyl-3-(2(pyrimidin-2-yl)phenyl)- $1 H$-indole 71 (69.0 mg, $0.242 \mathrm{mmol}, 81 \%$ yield) was obtained as a yellow oil. Rf: 0.40 (Pentane:EtOAc 4:1). IR $v 3048$ (w), 2932 (w), 1599 (w), 1568 (s), 1554 (m), 1473 (w), 1414 (s), 1377 (w), 1330

(w), 1268 (w), 1221 (w), 1162 (w), 1135 (w), 1015 (w), 943 (w), 822 (w). ${ }^{1}$ H NMR (400 MHz, $\left.\mathrm{CDCl}_{3}\right) \delta 8.58(\mathrm{~d}, J=4.9 \mathrm{~Hz}, 2 \mathrm{H}$, Pyrimidine $H), 7.84(\mathrm{dd}, J=7.7,1.5 \mathrm{~Hz}, 1 \mathrm{H}, \mathrm{Ar} H), 7.59$ (dd, $J=$ 7.7, $1.5 \mathrm{~Hz}, 1 \mathrm{H}, \operatorname{Ar} H), 7.51(\mathrm{~m}, 1 \mathrm{H}, \operatorname{Ar} H), 7.44(\mathrm{td}, J=7.5,1.5 \mathrm{~Hz}, 1 \mathrm{H}, \operatorname{Ar} H), 7.24(\mathrm{~d}, J=8.2 \mathrm{~Hz}$, $1 \mathrm{H}, \operatorname{Ar} H), 7.10(\mathrm{dd}, J=9.3,7.5 \mathrm{~Hz}, 2 \mathrm{H}, \operatorname{Ar} H), 7.03(\mathrm{~s}, 1 \mathrm{H}, \mathrm{NCHCI}), 7.00(\mathrm{t}, J=4.9 \mathrm{~Hz}, 1 \mathrm{H}, \operatorname{Ar} H)$, $6.84(\mathrm{t}, J=7.5 \mathrm{~Hz}, 1 \mathrm{H}, \mathrm{ArH}), 3.76\left(\mathrm{~s}, 3 \mathrm{H}, \mathrm{NCH}_{3}\right) .{ }^{13} \mathbf{C} \mathbf{N M R}\left(101 \mathrm{MHz}, \mathrm{CDCl}_{3}\right) \delta 168.5,156.7$, $138.1,136.7,134.1,131.3,130.7,129.4,127.5,126.8,126.5,121.3,119.3,119.2,118.2,116.2$, 109.0, 32.8 (two aromatic Carbon signals overlapping at 156.7). HR-ESI-MS $286.1344\left([\mathrm{M}+\mathrm{H}]^{+}\right.$, $\mathrm{C}_{19} \mathrm{H}_{16} \mathrm{~N}_{3}{ }^{+}$; calc. for 286.1339). 


\section{3-(2-(1H-Pyrazol-1-yl)phenyl)-1-methyl-1H-indole (72)}

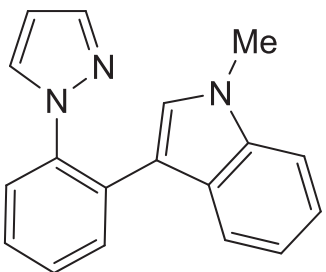

72

Starting from commercially available 1 -phenyl- $1 H$-pyrazole $(43.0 \mathrm{mg}, 0.300$

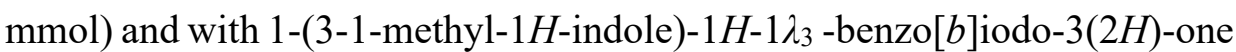
21 (124 mg, $0.330 \mathrm{mmol}, 1.10$ equiv.) at $80{ }^{\circ} \mathrm{C}$, 3-(2-( $1 H$-pyrazol-1yl)phenyl)-1-methyl-1H-indole 72 (59.0 $\mathrm{mg}, 0.216 \mathrm{mmol}, 72 \%$ yield) was obtained as a yellow oil. Rf: 0.40 (Pentane:EtOAc 4:1). IR v 3049 (w), 2926 (m), 2853 (w), $1680(\mathrm{w}), 1615$ (w), 1604 (w), 1548 (m), 1518 (s), 1473 (s), 1423 (w), 1394 (s), 1378 (s), 1329 (s), 1264 (w), 1221 (m), 1089 (m), 1045 (s), 1019 (m), 936 (s). ${ }^{1}$ H NMR (400 MHz, $\left.\mathrm{CDCl}_{3}\right) \delta 7.69(\mathrm{dd}, \mathrm{J}=7.8,1.6 \mathrm{~Hz}, 1 \mathrm{H}, \operatorname{Ar} H), 7.67(\mathrm{~d}, \mathrm{~J}=1.7 \mathrm{~Hz}, 1 \mathrm{H}, \operatorname{Ar} H), 7.62(\mathrm{dd}, \mathrm{J}=7.8,1.6$ $\mathrm{Hz}, 1 \mathrm{H}, \operatorname{Ar} H), 7.52-7.44(\mathrm{~m}, 2 \mathrm{H}, \operatorname{Ar} H), 7.40(\mathrm{td}, \mathrm{J}=7.8,1.6 \mathrm{~Hz}, 1 \mathrm{H}, \operatorname{Ar} H), 7.31(\mathrm{~d}, \mathrm{~J}=8.2 \mathrm{~Hz}$, 1H, $\operatorname{ArH}), 7.25-7.20$ (m, 2H, ArH), 7.07 (m, 1H, ArH), 6.60 (s, 1H, NCHC), 6.15 (m, 1H, ArH), $3.72(\mathrm{~s}, 3 \mathrm{H}, \mathrm{NCH}) .{ }^{13} \mathbf{C} \mathbf{N M R}\left(101 \mathrm{MHz}, \mathrm{CDCl}_{3}\right) \delta 139.9,138.5,136.7,131.1,131.0,130.6,128.2$, 127.6, 127.0, 126.9, 126.6, 121.8, 119.9, 119.3, 112.0, 109.3, 106.2, 32.8. HR-ESI-MS 274.1343 $\left([\mathrm{M}+\mathrm{H}]^{+}, \mathrm{C}_{18} \mathrm{H}_{16} \mathrm{~N}_{3}{ }^{+}\right.$; calc. for 274.1339).

\section{0-(1-Methyl-1 $H$-indol-3-yl)benzo[h]quinoline (73)}

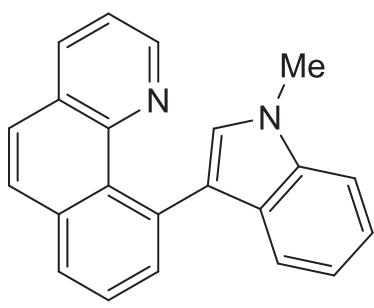

73

Starting from commercially available benzo[h]quinoline $(54.0 \mathrm{mg}, 0.300$ mmol) and with 1-(3-1-methyl-1H-indole)-1H-1 $\lambda_{3}$-benzo[ $\left.b\right]$ iodo-3(2H)one 21 (124 mg, $0.330 \mathrm{mmol}, 1.10$ equiv.) at $50{ }^{\circ} \mathrm{C}, 10$-(1-methyl- $1 H$ indol-3-yl)benzo[h]quinoline 73 (70.0 $\mathrm{mg}, 0.227 \mathrm{mmol}, 76 \%$ yield) was obtained as a light yellow oil. Rf: 0.40 (Pentane:EtOAc 4:1). IR $\vee 3046$ (m), 2929 (m), 1677 (w), 1615 (w), 1588 (m), 1569 (m), 1475 (s), 1418 (s), 1375 (s), 1323 (s), 1263 (w), 1230 (s), 1161 (w), 1129 (w), 1014 (w), 910 (m). ${ }^{1}$ H NMR (400 $\left.\mathrm{MHz} \mathrm{CDCl}_{3}\right) \delta 8.27(\mathrm{~d}, J=2.4 \mathrm{~Hz}, 1 \mathrm{H}, \operatorname{Ar} H), 8.10(\mathrm{dd}, J=8.0,1.9 \mathrm{~Hz}, 1 \mathrm{H}, \operatorname{Ar} H), 7.93-7.90(\mathrm{~m}$, 1H, $\operatorname{Ar} H), 7.88(\mathrm{~d}, J=8.7 \mathrm{~Hz}, 1 \mathrm{H}, \operatorname{Ar} H), 7.75-7.65$ (m, 3H, $\operatorname{Ar} H), 7.37$ (d, $J=8.2 \mathrm{~Hz}, 1 \mathrm{H}, \operatorname{Ar} H)$, 7.29 (m, 1H, ArH), 7.24 (m, 1H, ArH), 7.16 (ddd, $J=8.2,4.7,3.5 \mathrm{~Hz}, 1 \mathrm{H}, \operatorname{Ar} H), 6.79(\mathrm{~s}, 1 \mathrm{H}$, $\mathrm{NCHC}), 6.78(\mathrm{t}, J=1.1 \mathrm{~Hz}, 1 \mathrm{H}, \mathrm{ArH}), 3.93\left(\mathrm{~s}, 3 \mathrm{H}, \mathrm{NCH}_{3}\right) .{ }^{13} \mathbf{C} \mathbf{N M R}\left(101 \mathrm{MHz}, \mathrm{CDCl}_{3}\right) \delta 147.0$, $146.8,137.0,135.4,135.3,133.9,132.8,129.7,128.5,128.4,127.8,127.5,127.4,127.1,126.2$, 
125.7, 121.0, 120.8, 120.7, 118.5, 108.9, 32.9. HR-ESI-MS $309.1398\left([\mathrm{M}+\mathrm{H}]^{+}, \mathrm{C}_{22} \mathrm{H}_{17} \mathrm{~N}_{2}^{+}\right.$; calc. for 309.1386).

\section{1'-Methyl-1-(pyrimidin-2-yl)-1 H,1'H-2,3'-biindole (74)}

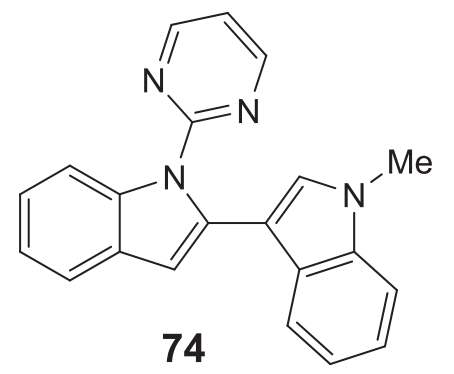

Starting from 1-(pyrimidin-2-yl)-1H-indole $123(59.0 \mathrm{mg}, 0.300$ mmol) and with 1-(3-1-methyl- $1 H$-indole)-1H-1 $\lambda_{3}$-benzo[b]iodo3(2H)-one 21 (124 mg, $0.330 \mathrm{mmol}, 1.10$ equiv.) at $50{ }^{\circ} \mathrm{C}, 1^{\prime}$-methyl1-(pyrimidin-2-yl)-1H,1'H-2,3'-biindole $74(80.0 \mathrm{mg}, 0.247 \mathrm{mmol}$, $82 \%$ yield) was obtained as a yellow oil. Rf: 0.38 (Pentane:EtOAc 4:1). IR $\vee 3049$ (w), 2931 (w), 1592 (w), 1563 (m), 1454 (m), 1423 (s), 1372 (w), 1350 (w), 1309 (m), 1258 (w), 1217 (w), 910 (w). ${ }^{1} \mathbf{H}$ NMR (400 MHz, CDCl $) \delta$ $8.51(\mathrm{~d}, J=4.8 \mathrm{~Hz}, 2 \mathrm{H}, \operatorname{Ar} H), 8.01(\mathrm{~m}, 1 \mathrm{H}, \operatorname{Ar} H), 7.56(\mathrm{dd}, J=7.9,1.3 \mathrm{~Hz}, 1 \mathrm{H}, \operatorname{Ar} H), 7.22-7.14$ (m, 3H, ArH), 7.13 (s, 1H, ArH), $7.06(\mathrm{dd}, J=8.3,6.9 \mathrm{~Hz}, 2 \mathrm{H}, \operatorname{Ar} H), 6.93(\mathrm{t}, J=4.8 \mathrm{~Hz}, 1 \mathrm{H}, \operatorname{Ar} H$ ), $6.82(\mathrm{td}, J=7.4,0.9 \mathrm{~Hz}, 1 \mathrm{H}, \mathrm{Ar} H), 6.69\left(\mathrm{~s}, 1 \mathrm{H}, \mathrm{CH}_{3} \mathrm{NCHC}\right), 3.71(\mathrm{~s}, 3 \mathrm{H}, \mathrm{NCH}) .{ }^{13} \mathbf{C} \mathbf{N M R}(101$ $\left.\mathrm{MHz}_{\mathrm{CDCl}}\right) \delta 158.2,158.2,137.5,136.8,134.6,129.6,127.8,126.8,122.6,121.8,121.7,120.0$, $119.8,119.5,117.5,112.4,109.3,108.9,106.5,32.9$. HR-ESI-MS $325.1452\left([\mathrm{M}+\mathrm{H}]^{+}, \mathrm{C}_{21} \mathrm{H}_{17} \mathrm{~N}_{4}^{+}\right.$; calc. for 325.1448).

\section{Methyl 3,5-bis(1-methyl-1H-indol-3-yl)-4-(pyridin-2-yl)benzoate (75)}

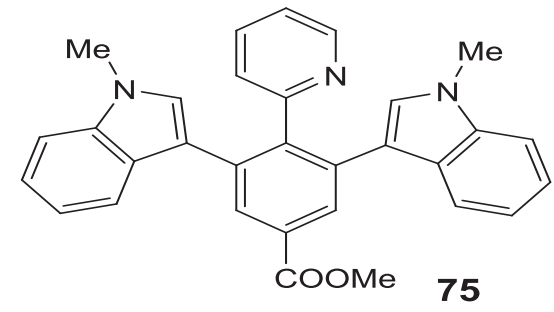

Starting from methyl 4-(pyridin-2-yl)benzoate $121(64.0 \mathrm{mg}$, $0.300 \mathrm{mmol})$ and with 1-(3-1-methyl-1H-indole) $-1 H-1 \lambda_{3}-$ benzo[ $b]$ iodo-3(2H)-one 21 (249 $\mathrm{mg}, 0.660 \mathrm{mmol}, 2.20$ equiv.) at $50{ }^{\circ} \mathrm{C}$, methyl 3,5-bis(1-methyl-1H-indol-3-yl)-4-(pyridin-2yl)benzoate 75 (75.0 mg, $0.159 \mathrm{mmol}, 53 \%$ yield) was obtained as a yellow oil. Rf: 0.30 (Pentane:EtOAc 4:1). IR $v 3056$ (w), 2950 (w), 2247 (w), 1720 (m), 1571 (m), 1477 (m), 1427 (m), 1325 (m), 1293 (s), 1247 (s), 1161 (m), 1119 (m), 1004 (m), 908 (s). ${ }^{1} \mathbf{H}$ NMR (400 MHz, CDCl $) \delta 8.47$ (m, 1H, ArH), 8.32 (s, 2H, $\operatorname{Ar} H), 7.68(\mathrm{~d}, J=8.0 \mathrm{~Hz}, 2 \mathrm{H}, \operatorname{Ar} H), 7.29-7.15(\mathrm{~m}, 5 \mathrm{H}, \operatorname{Ar} H), 7.08$ (ddd, $J=8.2,6.5,1.5 \mathrm{~Hz}, 2 \mathrm{H}$, $\operatorname{ArH}), 6.99-6.93$ (m, 2H, ArH), 6.52 (s, 2H, ArH), 3.94 (s, 3H, COOMe), 3.58 (s, 6H, NMe). ${ }^{13} \mathrm{C}$ NMR $\left(101 \mathrm{MHz}, \mathrm{CDCl}_{3}\right) \delta 167.2,159.8,147.9,143.2,136.4,135.6,135.4,129.7,128.9,127.3$, 
125.7, 121.6, 121.5, 119.8, 119.5, 114.5, 109.0, 52.1, 32.6. HR-ESI-MS 472.2021 $\left([\mathrm{M}+\mathrm{H}]^{+}\right.$, $\mathrm{C}_{31} \mathrm{H}_{25} \mathrm{~N}_{3} \mathrm{O}_{2}{ }^{+}$; calc. for 472.1998).

\section{8-(1-Methyl-1H-indol-3-yl)quinolin-2(1H)-one (76)}<smiles>Cn1cc(-c2cccc3ccc(=O)[nH]c23)c2ccccc21</smiles>

76

Starting from commercially available quinoline 1-oxide $(44.0 \mathrm{mg}, 0.300$ mmol) and with 1-(3-1-methyl-1H-indole)- $1 H-1 \lambda_{3}$-benzo[b]iodo-3(2H)-one 21 (124 mg, $0.330 \mathrm{mmol}, 1.10$ equiv.) at $100{ }^{\circ} \mathrm{C}, 8$-(1-methyl- $1 H$-indol-3yl)quinolin-2(1H)-one 76 (31.0 mg, $0.113 \mathrm{mmol}, 38 \%$ yield) was obtained as a yellow oil. Rf: 0.58 (EtOAc:MeOH 10:1). IR $v 3367$ (w), 3053 (w), 2923 (m), 2853 (w), $1715(\mathrm{w}), 1651$ (s), 1608 (m), 1541 (w), 1467 (m), 1372 (w), 1333 (w), 1234 (w), 1135 (w), 1014 (w), 840 (m). ${ }^{1} \mathbf{H}$ NMR (400 MHz, CDCl 3 ) $\delta 9.02$ (s, 1H, $\mathrm{NHCO}), 7.83(\mathrm{~d}, J=9.5 \mathrm{~Hz}, 1 \mathrm{H}, \operatorname{Ar} H), 7.61-7.54(\mathrm{~m}, 2 \mathrm{H}, \operatorname{Ar} H), 7.45(\mathrm{dd}, J=8.3,6.7 \mathrm{~Hz}, 2 \mathrm{H}$, $\operatorname{ArH}), 7.34(\mathrm{~m}, 1 \mathrm{H}, \operatorname{Ar} H), 7.30(\mathrm{~d}, J=7.6 \mathrm{~Hz}, 1 \mathrm{H}, \operatorname{Ar} H), 7.23$ (s, 1H, NCHC), $7.20-7.15(\mathrm{~m}, 1 \mathrm{H}$, Indole $H), 6.66(\mathrm{~d}, J=9.3 \mathrm{~Hz}, 1 \mathrm{H}, \mathrm{Ar} H), 3.91(\mathrm{~s}, 3 \mathrm{H}, \mathrm{NCH}) .{ }^{13} \mathbf{C ~ N M R}\left(101 \mathrm{MHz}, \mathrm{CDCl}_{3}\right) \delta 162.4$, $141.0,136.3,132.2,127.8,127.7,126.9,126.7,122.9,122.4,121.9,121.6,120.6,120.0,119.4$, 109.8, 109.4, 33.1. HR-ESI-MS $275.1185\left([\mathrm{M}+\mathrm{H}]^{+}, \mathrm{C}_{18} \mathrm{H}_{15} \mathrm{~N}_{2} \mathrm{O}^{+}\right.$; calc. for 275.1179).

(2R,3R,4R,5R)-2-(Acetoxymethyl)-5-(6-(2-(1-methyl-1H-indol-3-yl)phenyl)-9H-purin-9yl)tetrahydrofuran-3,4-diyl diacetate (77)

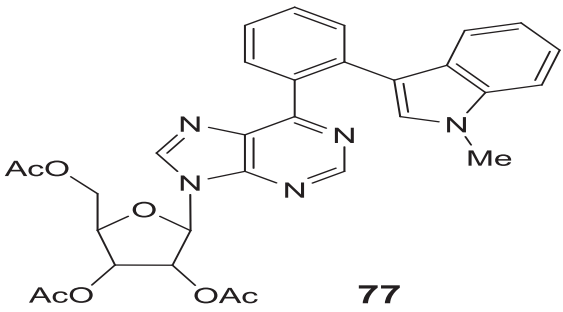

Starting from $(2 R, 3 R, 4 R, 5 R)-2$-(acetoxymethyl)-5-(6phenyl-9H-purin-9-yl)tetrahydrofuran-3,4-diyl diacetate 127 (136 mg, $0.300 \mathrm{mmol})$ and with 1-(3-1-methyl-1H-indole)$1 H-1 \lambda_{3}$-benzo[b]iodo-3(2H)-one 21 (124 mg, $0.330 \mathrm{mmol}$, 1.10 equiv.) at $50{ }^{\circ} \mathrm{C},(2 R, 3 R, 4 R, 5 R)-2$-(Acetoxymethyl)-5(6-(2-(1-methyl-1H-indol-3-yl)phenyl)-9H-purin-9yl)tetrahydrofuran-3,4-diyl diacetate 77 (72 mg, $0.123 \mathrm{mmol}$, $41 \%$ yield)) was obtained as a yellow oil. Rf: 0.65 (EtOAc 100\%). IR v 3056 (w), 2934 (w), 2825 (w), 2254 (w), 1749 (s), 1586 (m), 1505 (w), 1484 (w), 1435 (w), 1377 (m), 1332 (m), 1219 (s), 1101 (m), 1048 (m), 912 (m), 817 (w). ${ }^{1}$ H NMR (400 $\left.\mathrm{MHz}_{\mathrm{CDCl}}\right) \delta 8.81(\mathrm{~s}, 1 \mathrm{H}, \mathrm{Ar} H), 8.04(\mathrm{~s}, 1 \mathrm{H}, \mathrm{Ar} H), 7.76(\mathrm{dd}, J=7.6,1.4 \mathrm{~Hz}, 1 \mathrm{H}, \mathrm{Ar} H), 7.70(\mathrm{dd}$, 
$J=7.6,1.3 \mathrm{~Hz}, 1 \mathrm{H}, \operatorname{Ar} H), 7.56(\mathrm{td}, J=7.6,1.5 \mathrm{~Hz}, 1 \mathrm{H}, \operatorname{Ar} H), 7.46(\mathrm{td}, J=7.5,1.3 \mathrm{~Hz}, 1 \mathrm{H}, \operatorname{Ar} H)$, $7.30-7.23\left(\mathrm{~m}, 1 \mathrm{H}, \mathrm{Ar} H+C D C_{3}\right), 7.18(\mathrm{~d}, J=8.3 \mathrm{~Hz}, 1 \mathrm{H}, \mathrm{Ar} H), 7.08(\mathrm{ddd}, J=8.1,7.0,1.1 \mathrm{~Hz}$, $1 \mathrm{H}, \operatorname{Ar} H), 6.90(\mathrm{~s}, 1 \mathrm{H}, \operatorname{Ar} H), 6.86(\mathrm{ddd}, J=8.0,6.9,1.0 \mathrm{~Hz}, 1 \mathrm{H}, \operatorname{Ar} H), 6.18(\mathrm{~d}, J=5.1 \mathrm{~Hz}, 1 \mathrm{H}$, $\mathrm{CH}), 5.89(\mathrm{t}, J=5.3 \mathrm{~Hz}, 1 \mathrm{H}, \mathrm{CH}), 5.65(\mathrm{dd}, J=5.5,4.5 \mathrm{~Hz}, 1 \mathrm{H}, \mathrm{CH}), 4.47-4.40(\mathrm{~m}, 2 \mathrm{H}, \mathrm{CH}+$ $\left.\mathrm{CH}_{2}\right), 4.34$ (dd, $\left.J=13.1,5.2 \mathrm{~Hz}, 1 \mathrm{H}, \mathrm{CH}_{2}\right), 3.67$ (s, 3H, NMe), 2.14 (s, 3H, COCH $), 2.08(\mathrm{~s}, 3 \mathrm{H}$, $\left.\mathrm{COCH}_{3}\right), 2.06\left(\mathrm{~s}, 3 \mathrm{H}, \mathrm{COCH}_{3}\right) .{ }^{13} \mathbf{C} \mathbf{~ N M R}\left(101 \mathrm{MHz}, \mathrm{CDCl}_{3}\right) \delta 170.3,169.5,169.2,160.3,152.3$, 151.0, 142.4, 136.6, 134.7, 134.2, 132.9, 131.3, 131.0, 129.8, 128.2, 126.9, 126.2, 121.4, 119.5, 119.2, 115.4, 109.0, 86.3, 80.2, 73.0, 70.5, 62.9, 32.7, 20.7, 20.5, 20.4. HR-ESI-MS 584.2138 $\left([\mathrm{M}+\mathrm{H}]^{+}, \mathrm{C}_{31} \mathrm{H}_{30} \mathrm{~N}_{5} \mathrm{O}_{7}^{+}\right.$; calc. for 584.2140). 


\section{Ru-Catalyzed C-H Indolization of Arenes via C-H activation.}

All commercially available chemicals were purchased from the suppliers quoted in Paragraph 1.0 of Supplementary Informations: these chemicals were purified through a short plug of celite prior to their use in catalysis. The synthesis of non commercial available compounds is presented below.

The synthesis of the starting materials 14, 53-62 the optimization process of compound 79 and products 79, 85-94 had been already described before. ${ }^{[1]}$ The procedures here reported are taken from the cited publication to facilitate reproduction of the results by having all the data in the same file.

\subsection{Preparation of starting materials for Ru-Catalyzed C-H activation.}<smiles>O=C(Cl)C1=CC=CC=[R]=C1</smiles>
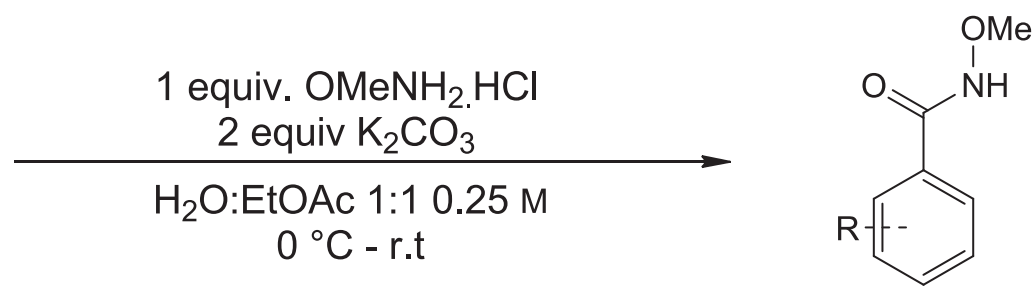

GP5: Following a reported procedure, ${ }^{[35]}$ O-methylhydroxylamine hydrochloride $(0.418 \mathrm{~g}, 5.00$ mmol, 1.00 equiv.) was added to a solution of $\mathrm{K}_{2} \mathrm{CO}_{3}(1.38 \mathrm{~g}, 10.0 \mathrm{mmol}, 2.00$ equiv) in a mixture of EtOAc/ $\mathrm{H}_{2} \mathrm{O}(20 \mathrm{~mL}, 1: 10.25 \mathrm{M})$ under vigorous stirring. Then the reaction mixture was cooled to $0{ }^{\circ} \mathrm{C}$ and the corresponding (substituted) benzoyl chloride (5.00 mmol, 1.00 equiv) was added dropwise or portionwise. The reaction mixture was warmed to room temperature and stirred for additional 2 hours. The organic layer was separated and the aqueous layer was extracted with EtOAc $(3 \times 10 \mathrm{~mL})$. The combined organic layers were dried over $\mathrm{MgSO}_{4}$, filtered, and the solvent removed under reduced pressure. The crude product was purified by flash column chromatography (Pentane:EtOAc 2:1) to afford the desired N-methoxy benzamides 78, 129-138. 
<smiles>CONC(=O)c1ccccc1</smiles>

78

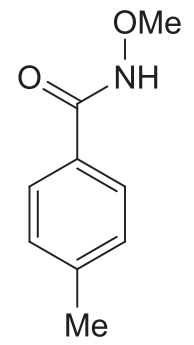

129

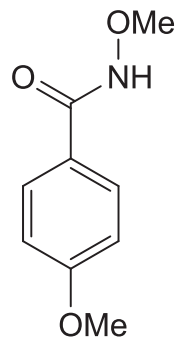

130

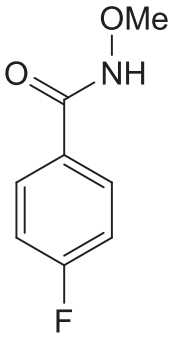

131<smiles>CONC(=O)c1ccc(Br)cc1</smiles>

132<smiles>CONC(=O)c1cccc(C)c1</smiles>

133<smiles>CONC(=O)c1ccc2c(c1)OCO2</smiles>

137<smiles>CONC(=O)c1cccc(C(F)(F)F)c1</smiles>

134<smiles>CONC(=O)c1cccc2ccccc12</smiles>

138

Figure S10: Starting materials for Ru-catalyzed Indolization of Arenes via C-H activation.. 


\section{N-Methoxybenzamide (78)}

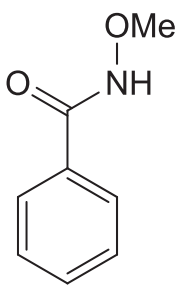

78

The synthesis of $\mathrm{N}$-methoxybenzamide 14 was scaled up to $10 \mathrm{mmol}$ without reoptimization of the protocol.

Starting from commercially available benzoyl chloride $(1.15 \mathrm{~mL}, 10.0 \mathrm{mmol}), \mathrm{N}-$ methoxybenzamide 78 (1.20 g, $7.94 \mathrm{mmol}, 79 \%$ yield) was obtained as a colorless solid. IR $v 3197$ (w), 2980 (w), 2935 (w), 1646 (s), 1579 (m), 1516 (m), 1484 (m), 1310 (m), 1154 (w), 1045 (m), 1026 (m), 945 (w), 881 (s). ${ }^{1} \mathbf{H}$ NMR (400 MHz, CDCl3) $\delta 10.70$ (s, $\left.1 \mathrm{H}, \mathrm{NHOCH}_{3}\right), 7.70(\mathrm{dd}, J=8.3,1.4 \mathrm{~Hz}, 2 \mathrm{H}, \mathrm{Ar} H), 7.38$ (m, 1H, $\left.\mathrm{Ar} H\right), 7.26$ (ddd, $J=8.3,6.6$, $1.3 \mathrm{~Hz}, 2 \mathrm{H}, \mathrm{ArH}), 3.69$ (s, 3H, $\left.\mathrm{NHOCH}_{3}\right) .{ }^{13} \mathbf{C ~ N M R}\left(100 \mathrm{MHz}, \mathrm{CDCl}_{3}\right) \delta 166.2,131.7,128.3$, 127.1, 63.9, 53.3. NMR values are in accordance with the data reported in literature. ${ }^{[34]}$

\section{N-Methoxy-4-methylbenzamide (129)}

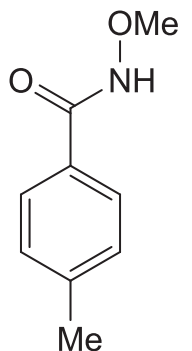

129

Starting from commercially available 4-methylbenzoyl chloride (775 mg, 5.00 mmol), N-methoxy-4-methylbenzamide 129 (822 mg, $4.98 \mathrm{mmol}, 100 \%$ yield) was obtained as a colorless solid. IR $v 3201$ (w), 2975 (w), 2935 (w), 1646 (s), 1572 (w), 1494 (m), 1439 (w), 1308 (m), 1155 (w), 1043 (s), 1020 (m), 943 (w), 883 (s), 833 (m). ${ }^{1} \mathbf{H}$ NMR (400 MHz, $\left.\mathrm{CDCl}_{3}\right) \delta 10.73$ (brs, $1 \mathrm{H}, \mathrm{NHOCH}$ ), 7.67 (d, $J=8.2 \mathrm{~Hz}$, 2H, $\mathrm{ArH}), 7.10(\mathrm{~d}, J=8.0 \mathrm{~Hz}, 2 \mathrm{H}, \mathrm{Ar} H), 3.74\left(\mathrm{~s}, 3 \mathrm{H}, \mathrm{NHOCH}_{3}\right), 2.30\left(\mathrm{~s}, 3 \mathrm{H}, \mathrm{ArCH}_{3}\right)$. ${ }^{13}$ C NMR (100 MHz, $\left.\mathrm{CDCl}_{3}\right) \delta$ (ppm) 166.2, 142.1, 128.9, 127.1, 63.8, $21.2(2$ aromatic Carbon signals overlapping at 128.9). NMR values are in accordance with the data reported in literature. ${ }^{[34]}$

\section{N,4-dimethoxybenzamide (130)}

Starting from commercially available 4-methoxybenzoyl chloride (853 mg, 5.00 mmol), 4-fluoro- N,4-dimethoxybenzamide 130 ( $890 \mathrm{mg}$, $4.91 \mathrm{mmol}$, 98\% yield) was obtained as a white solid. IR $v 3205$ (w), 2972 (w), 2938 (w), 1644 (m), 1606 (s), 1496 (m), 1255 (s), 1181 (m), 1159 (m), 1027 (s), 884 (m), 844 (m). ${ }^{1}$ H NMR (400 $\left.\mathrm{MHz}, \mathrm{CDCl}_{3}\right) \delta 10.67(\mathrm{~s}, 1 \mathrm{H}, \mathrm{N} H \mathrm{OMe}), 7.77(\mathrm{~d}, J=8.9 \mathrm{~Hz}, 2 \mathrm{H}, \mathrm{Ar} H), 6.81(\mathrm{~d}, J=$ $8.4 \mathrm{~Hz}, 2 \mathrm{H}, \mathrm{ArH}), 3.77$ (s, 3H, NHOMe), 3.76 (s, 3H, ArOMe). ${ }^{13} \mathrm{C}$ NMR (100 MHz, $\left.\mathrm{CDCl}_{3}\right) \delta 162.2,132.6,128.9,114.0,113.5,63.8,55.1$. NMR values are in accordance with the data reported in literature. ${ }^{[34]}$ 


\section{4-Fluoro-N-methoxybenzamide (131)}

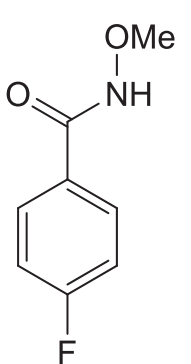

131

Starting from commercially available 4-fluorobenzoyl chloride (793 mg, $5.00 \mathrm{mmol}$ ), 4-fluoro-N-methoxybenzamide 131 (643 mg, $3.80 \mathrm{mmol}, 76 \%$ yield) was obtained as a colorless solid. IR $v 3210$ (w), 2984 (w), 2941 (w), 1656 (s), 1592 (s), 1481 (s), 1439 (w), 1318 (w), 1154 (w), 1072 (s), 1012 (s), 944 (w), 879 (s), 841 (m). ${ }^{1}$ H NMR $\left(400 \mathrm{MHz}, \mathrm{CDCl}_{3}\right) \delta 11.29$ (s, 1H, NHOMe), 7.78 (m, 2H, ArH), $6.96(\mathrm{~m}, 2 \mathrm{H}, \mathrm{ArH})$, $3.72(\mathrm{~s}, 3 \mathrm{H}, \mathrm{NHOMe}) .{ }^{13} \mathrm{C}$ NMR $\left(101 \mathrm{MHz}, \mathrm{CDCl}_{3}\right) 165.2,164.7(\mathrm{~d}, J=252.5 \mathrm{~Hz})$, $129.6(\mathrm{~d}, J=9.0 \mathrm{~Hz}), 127.6(\mathrm{~d}, J=3.3 \mathrm{~Hz}), 115.3(\mathrm{~d}, J=22.0 \mathrm{~Hz}), 63.7$. NMR data is corresponding to the reported values. ${ }^{[34]}$

\section{4-Bromo-N-methoxybenzamide (132)}

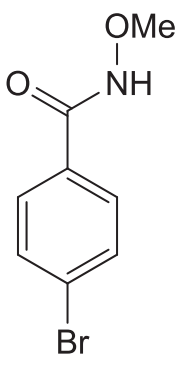

132

Starting from commercially available 4-bromobenzoyl chloride $(1.09 \mathrm{~g}, 5.00 \mathrm{mmol})$, 4-bromo-N-methoxybenzamide 132 (700 mg, $3.04 \mathrm{mmol}, 61 \%$ yield) was obtained as a colorless solid. IR $v 3059$ (w), 3006 (w), 1647 (s), 1604 (s), 1497 (s), 1267 (s), 1237 (s), 1158 (m), 1041 (m), 885 (m), 850 (s). ${ }^{1} \mathbf{H}$ NMR (400 MHz, $\left.\mathrm{CDCl}_{3}\right) \delta 10.59$ (brs, $\left.1 \mathrm{H}, \mathrm{NHOCH}_{3}\right), 7.56$ (d, $\left.J=8.5 \mathrm{~Hz}, 2 \mathrm{H}, \mathrm{ArH}\right), 7.41$ (d, $\left.J=8.6 \mathrm{~Hz}, 2 \mathrm{H}\right), 3.71$ (s, $3 \mathrm{H}, \mathrm{NHOCH}) .{ }^{13} \mathrm{C}$ NMR $\left(100 \mathrm{MHz}, \mathrm{CDCl}_{3}\right) \delta 165.4,131.7,130.4,128.8,126.7$, 64.1. ${ }^{1} \mathrm{H}$ NMR data is corresponding to the reported values. ${ }^{[34]}$

\section{N-Methoxy-3-methylbenzamide (133)}

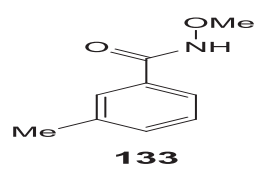

Starting from commercially available 3-methylbenzoyl chloride (775 mg, 5.00 mmol), N-methoxy-3-methylbenzamide 133 (813 mg, 4.92 mmol, 98\% yield) was obtained as a white solid. IR $v 3004$ (w), 2953 (w), 1726 (s), 1650 (m), 1516 (w), 1439 (m), 1303 (m), 1264 (s), 1156 (m), 1109 (w), 982 (w), $826\left(\right.$ w). ${ }^{1} \mathbf{H}$ NMR $\left(400 \mathrm{MHz}, \mathrm{CDCl}_{3}\right) \delta(\mathrm{ppm}) 11.09(\mathrm{~s}, 1 \mathrm{H}, \mathrm{NHOCH}), 8.37$ (s, $\left.1 \mathrm{H}, \mathrm{ArH}\right)$, $8.03(\mathrm{dt}, J=7.8,1.5 \mathrm{~Hz}, 1 \mathrm{H}), 7.98(\mathrm{dt}, J=7.8,1.5 \mathrm{~Hz}, 1 \mathrm{H}), 7.39$ (t, $J=7.8 \mathrm{~Hz}$, $1 \mathrm{H}), 3.78\left(\mathrm{~s}, 6 \mathrm{H}, \mathrm{NHOMe}+\mathrm{ArCH}_{3}\right) .{ }^{13} \mathbf{C}$ NMR $\left(101 \mathrm{MHz}, \mathrm{CDCl}_{3}\right) \delta 166.0,132.4,132.0,131.6$, 130.1, 128.5, 128.1, 63.9, 52.1. NMR values are in accordance with the data reported in literature. $^{[34]}$ 


\section{N-Methoxy-3-(trifluoromethyl)benzamide (134)}<smiles>CONC(=O)c1cccc(C(F)(F)F)c1</smiles>

134

Starting from commercially available 3-(trifluoromethyl)benzoyl chloride (1.04 g, $5.00 \mathrm{mmol}$ ), N-methoxy-4-methylbenzamide 134 (822 mg, $3.75 \mathrm{mmol}, 75 \%$ yield) was obtained as a colorless solid. IR $v 3190$ (w), 2995 (w), 1656 (m), 1522 (w), 1440 (w), 1330 (s), 1283 (m), 1169 (s), 1125 (s), 1075 (m), 909 (w). ${ }^{1} \mathbf{H}$ NMR (400 MHz, $\left.\mathrm{CDCl}_{3}\right) \delta 9.60\left(\mathrm{~s}, 1 \mathrm{H}, \mathrm{NHOCH}_{3}\right), 8.02(\mathrm{~s}, 1 \mathrm{H}, \mathrm{ArH}), 7.95$ (d, $\mathrm{J}=8.1 \mathrm{~Hz}, 1 \mathrm{H}, \mathrm{ArH}), 7.56(\mathrm{t}, \mathrm{J}=7.8 \mathrm{~Hz}, 1 \mathrm{H}, \mathrm{ArH}), 3.87\left(\mathrm{~s}, 3 \mathrm{H}, \mathrm{NHOCH}_{3}\right) .{ }^{13} \mathbf{C}$ NMR $\left(100 \mathrm{MHz}, \mathrm{CDCl}_{3}\right) \delta 168.3,130.5,129.3,128.7,128.6,124.2,124.2,123.5$ (q, $\mathrm{J}_{\mathrm{F}}=272.6$ $\mathrm{Hz})$, 64.6. NMR values are in accordance with the data reported in literature. ${ }^{[36]}$

\section{3-Fluoro-N-methoxybenzamide (135)}<smiles>CONC(=O)c1cccc(F)c1</smiles>

135

Starting from commercially available 3-fluorobenzoyl chloride $(775 \mathrm{mg}, 5.00$ mmol), 3-fluoro-N-methoxybenzamide $\mathbf{1 3 5}^{1}$ (710 $\mathrm{mg}, 4.20 \mathrm{mmol}, 84 \%$ yield) was obtained as a colorless solid. Mp: $67.9^{\circ} \mathrm{C}$. IR 2979 (w), 2940 (w), 1652 (s), 1587 (s), 1519 (m), 1483 (m), 1226 (s), 1046 (m), 937 (m), 816 (s). ${ }^{1}$ H NMR (400 MHz, $\left.\mathrm{CDCl}_{3}\right) \delta 10.76$ (brs, $1 \mathrm{H}, \mathrm{NHOCH}$ ), 7.57 (m, 1H, $\mathrm{ArH}$ ), 7.50 (ddd, $J=9.4,2.6$, $1.6 \mathrm{~Hz}, 1 \mathrm{H}, \operatorname{Ar} H), 7.30-7.21(\mathrm{~m}, 1 \mathrm{H}, \operatorname{Ar} H), 7.08(\mathrm{t}, J=8.8 \mathrm{~Hz}, 1 \mathrm{H}, \operatorname{Ar} H), 3.73$ $(\mathrm{s}, 3 \mathrm{H}, \mathrm{NHOCH}) .{ }^{13} \mathrm{C}$ NMR $\left(101 \mathrm{MHz}, \mathrm{CDCl}_{3}\right) \delta 165.0,162.4(\mathrm{~d}, J=247.6 \mathrm{~Hz}), 133.7(\mathrm{~d}, J=$ $6.9 \mathrm{~Hz}), 130.1$ (d, $J=7.8 \mathrm{~Hz}), 122.8,118.9$ (d, $J=21.2 \mathrm{~Hz}), 114.4(\mathrm{~d}, J=23.3 \mathrm{~Hz}), 64.0 . \mathbf{M p}$ and IR significative values are in accordance with the data reported in literature. ${ }^{[37]}$

\section{3-Chloro-N-methoxybenzamide (136)}

六: Starting from commercially available 3-chlorobenzoyl chloride (875 g, 5.00 mmol), 3-chloro-N-methoxybenzamide 136 (830 mg, $4.47 \mathrm{mmol}, 89 \%$ yield) was obtained as a white solid. IR $v 3187$ (w), 3006 (w), 2937 (w), 1646 (s), 1572 (s), 1519 (m), 1471 (m), 1298 (m), 1162 (m), 1048 (m), 944 (m), 904 (m). ${ }^{\mathbf{1} H}$ NMR (400 MHz, $\left.\mathrm{CDCl}_{3}\right): \delta 9.90$ (br s, $\left.1 \mathrm{H}, \mathrm{NHOCH}_{3}\right), 7.75(\mathrm{~s}, 1 \mathrm{H}, \mathrm{ArH}), 7.64$ (d, $J=$ $7.8 \mathrm{~Hz}, 1 \mathrm{H}, \operatorname{Ar} H), 7.45(\mathrm{dd}, J=8.1,2.1 \mathrm{~Hz}, 1 \mathrm{H}, \operatorname{Ar} H), 7.32(\mathrm{t}, J=7.9 \mathrm{~Hz}, 1 \mathrm{H}$,

1: Compound $\mathbf{5 9}$ is purchaseable via Adlab Chemicals Building Blocks and Aurora Building Blocks. 
$\mathrm{ArH}), 3.83$ (s, 3H, $\left.\mathrm{NHOCH}_{3}\right) .{ }^{13} \mathbf{C}$ NMR (101 MHz, $\left.\mathrm{CDCl}_{3}\right): \delta 165.1,134.7,133.4,132.0,129.9$, $127.5,125.3,64.4$. NMR values are in accordance with the data reported in literature. ${ }^{[38]}$

\section{N-Methoxybenzo $[d][1,3]$ dioxole-5-carboxamide (137)}

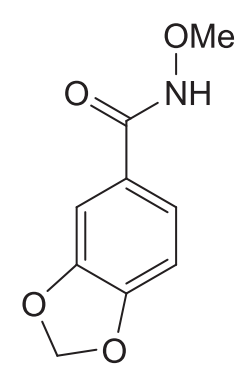

137

Starting from commercially available benzo $[d][1,3]$ dioxole-5-carbonyl chloride (923 mg, $5.00 \mathrm{mmol})$, N-methoxybenzo[d][1,3]dioxole-5-carboxamide 137 (865 mg, 4.43 mmol, 89\% yield) was obtained as a white solid. Rf: 0.4 (Pentane:EtOAc 4:1). IR v 2982 (w), 2938 (w), 1650 (m), 1605 (m), 1478 (s), 1438 (m), 1300 (m), 1252 (s), 1093 (m), 1034 (s), 927 (s), 839 (m). ${ }^{1} \mathbf{H}$ NMR (400 MHz, CDCl 3 ) $\delta$ 10.59 (br s, $\left.1 \mathrm{H}, \mathrm{NHOCH}_{3}\right), 7.31$ (d, $\left.J=8.2,1.8 \mathrm{~Hz}, 1 \mathrm{H}, \operatorname{Ar} H\right), 7.23$ (s, $1 \mathrm{H}, \operatorname{Ar} H$ ), $6.69(\mathrm{~d}, J=8.1, \mathrm{~Hz}, 1 \mathrm{H}, \mathrm{ArH}), 5.92\left(\mathrm{~s}, 2 \mathrm{H}, \mathrm{OCH}_{2} \mathrm{O}\right), 3.75\left(\mathrm{~s}, 3 \mathrm{H}, \mathrm{NHOCH}_{3}\right) .{ }^{13} \mathrm{C}$ NMR $\left(101 \mathrm{MHz}, \mathrm{CDCl}_{3}\right) \delta 165.7,150.4,147.6,125.5,122.1,107.8,107.5,101.5,63.9$. HR-ESIMS $196.0604\left([\mathrm{M}+\mathrm{H}]^{+}, \mathrm{C}_{9} \mathrm{H}_{10} \mathrm{NO}_{4}{ }^{+}\right.$; calc. for 196.0604).

\section{N-Methoxy-1-naphthamide (138)}<smiles>CONC(=O)c1cccc2ccccc12</smiles>

138

\section{For this starting material the synthesis was performed on $1.00 \mathrm{mmol}$ scale}

Starting from commercially available 1-naphthoyl chloride (191 mg, 1.00 mmol), N-methoxy-1-naphthamide 138 (183 mg, $0.909 \mathrm{mmol}, 91 \%$ yield) was obtained as a white solid. IR 2943 (w), 2907 (w), 2827 (w), 1631 (s), 1617 (s), 1591 (m), 1537 (w), 1318 (w), 1262 (w), 1063 (m), 958 (m), 889 (w). ${ }^{1}$ H NMR $\left(300 \mathrm{MHz}, \mathrm{DMSO}-d_{6}\right) \delta 8.72\left(\right.$ br s, $\left.1 \mathrm{H}, \mathrm{N} H \mathrm{OCH}_{3}\right), 8.28(\mathrm{~m}, 1 \mathrm{H}, \mathrm{ArH}), 8.10$ $7.90(\mathrm{~m}, 2 \mathrm{H}, \mathrm{ArH}), 7.71-7.41(\mathrm{~m}, 4 \mathrm{H}, \mathrm{ArH}), 3.94$ (s, 3H, NHOCH$).{ }^{13} \mathbf{C} \mathbf{~ N M R}\left(75 \mathrm{MHz}, \mathrm{CDCl}_{3}\right)$ $\delta 167.3,133.6,131.4,130.3,129.6,128.3,127.4,126.6,125.6,125.1,124.5,64.8$. NMR values are in accordance with the data reported in literature. ${ }^{[39]}$ 


\subsection{Optimization of the Ru-Catalyzed Indolization of Arenes via C-H activation.}

GP5: In a vial, N-methoxybenzamide 78 (15.0 mg, $0.100 \mathrm{mmol}), 1$-(3-1-methyl-1H-indole)- $1 H$ $1 \lambda_{3}$-benzo[b]iodo-3(2H)-one 21 (1.10 equiv.), [RuCl 2 (p-cymene) $]_{2} 139$ (2.45 mg, $4.00 \mu \mathrm{mol}, 4$ $\mathrm{mol} \%)$ and the relative additives $(16 \mathrm{~mol} \%)$ were dissolved in the specified dry solvent $(0.1 \mathrm{M})$ under nitrogen. the reaction mixture was degassed (freeze-thaw-pump) and stirred at the reported $\mathrm{T}$ in ${ }^{\circ} \mathrm{C}$ overnight. Then the reaction was stopped, the organic layer washed with a saturated solution of $\mathrm{NaHCO}_{3}(2 \mathrm{ml})$ and the solvent removed under reduced pressure. Flash column chromatography (Pentane:EtOAc 2:1) afforded the desired product (see compound 79's characterization for all the chemical data).

Table S9: Screening of solvents<smiles>CCCCCCCCCCOC(=O)c1ccccc1I</smiles><smiles>CONC(=O)c1ccccc1</smiles>

78
1.1 equiv.

$16 \mathrm{~mol} \% \mathrm{NaOAc}$

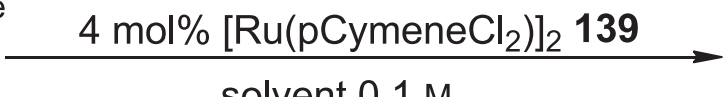

solvent $0.1 \mathrm{M}$

$60{ }^{\circ} \mathrm{C}$

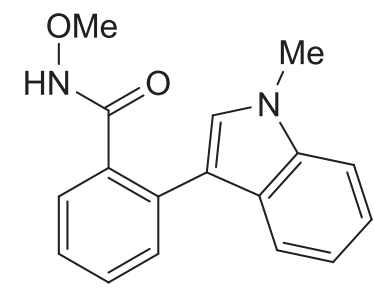

79

\begin{tabular}{ccc}
\hline Entry & Solvent & Yield\%a $^{\mathbf{a}}$ \\
\hline 1 & DCM & - \\
2 & DCE & - \\
$\mathbf{3}$ & MeOH & $\mathbf{4 3 \%}$ \\
4 & EtOH & $34 \%$ \\
5 & $t$-BuOH & - \\
6 & t-AmylOH & - \\
7 & Toluene & - \\
8 & Xylene & - \\
9 & Dioxane & $28 \%$
\end{tabular}




\begin{tabular}{|c|c|c|}
\hline 10 & $\mathrm{MeCN}$ & - \\
\hline 1 & DMF & - \\
\hline 12 & 2,2,2-Trifluoroethanol (TFE) & $55 \%$ \\
\hline 13 & Hexafluoroisopropanol (HFIP) & $30 \%$ \\
\hline 12 & $\begin{array}{c}\text { Nonafluoroisopropanol } \\
\text { (NFIP):HFIP 1:9 }\end{array}$ & - \\
\hline 1 & HFIP:DCE 9:1 & - \\
\hline 16 & HFIP:DCE 8:2 & $35 \%$ \\
\hline $1^{\prime}$ & HFIP:DCE 1:1 & - \\
\hline 18 & Monofluoroethanol (MFE) & $21 \%$ \\
\hline
\end{tabular}

Table S10: Screening of the Temperature

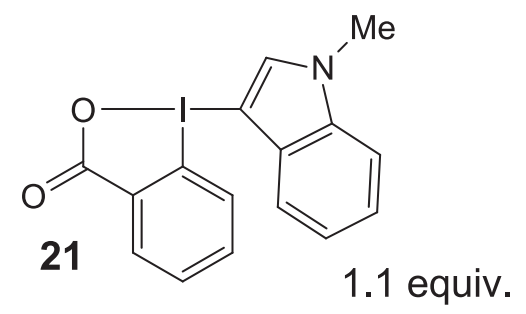<smiles>CONC(=O)c1ccccc1</smiles>

78<smiles>CONC(=O)c1ccccc1-c1cn(C)c2ccccc12</smiles>

79

\begin{tabular}{|c|c|c|}
\hline Entry & $\bar{T}$ & Yield\% ${ }^{a}$ \\
\hline 1 & r.t & $-b$ \\
\hline 2 & 40 & low conversion ${ }^{\mathrm{b}}$ \\
\hline 3 & 60 & $55 \%$ \\
\hline 4 & 80 & low conversion ${ }^{\mathrm{c}}$ \\
\hline 5 & 120 & $-\mathrm{c}$ \\
\hline
\end{tabular}


${ }^{\circ} \mathrm{C}$. Isolated yield after flash chromatography is given. b) clean reaction, starting material recovered. c) decomposition occurred.

Table S11: Screening of the base
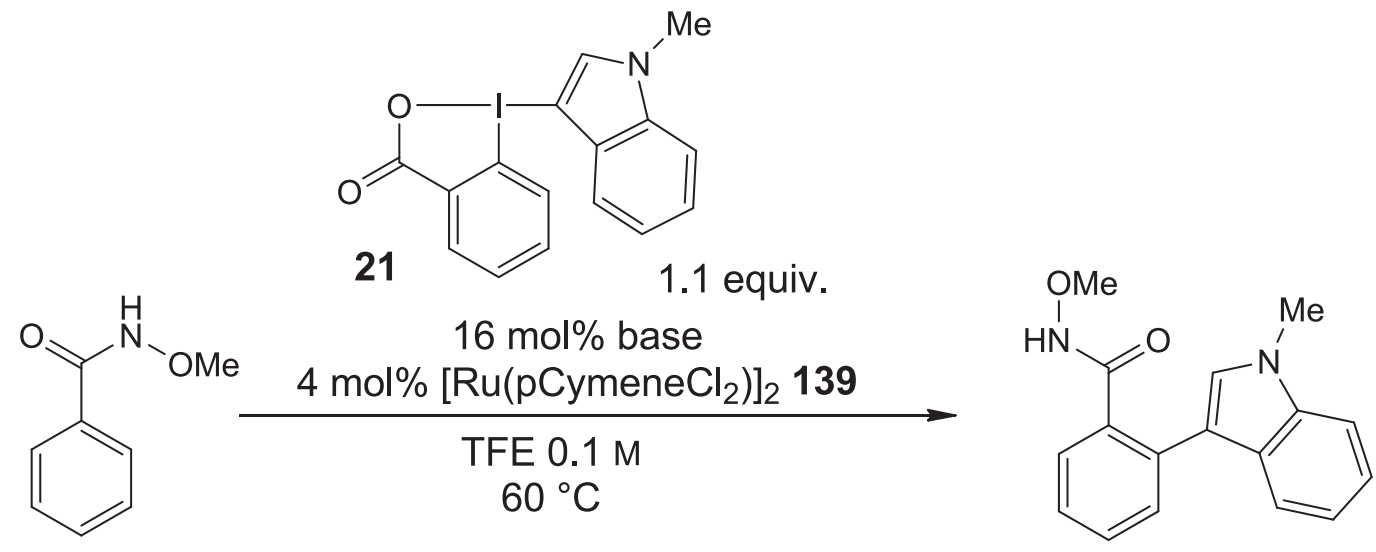

78

79

\begin{tabular}{|c|c|c|}
\hline Entry & Base & Yield\% $\%^{a}$ \\
\hline 1 & LiOPiv & - \\
\hline 2 & $\mathrm{Li}_{2} \mathrm{CO}_{3}$ & - \\
\hline 3 & LiMes & $-b$ \\
\hline 4 & $\mathrm{NaOAc}$ & $55 \%$ \\
\hline 5 & $\mathrm{Na}_{2} \mathrm{CO}_{3}$ & - \\
\hline 6 & NaOPiv & $50 \%$ \\
\hline 7 & NaMes & $34 \%$ \\
\hline 8 & 63 & -b \\
\hline 9 & 64 & $68 \%{ }^{c}$ \\
\hline 10 & 65 & $65 \%{ }^{\mathrm{b}}$ \\
\hline 11 & 66 & $66 \%$ b \\
\hline 12 & KOAc & - \\
\hline 13 & KOPiv & - \\
\hline 14 & KMes & $26 \% \mathrm{~b}$ \\
\hline 15 & CsOPiv & - \\
\hline 16 & $\mathrm{Cs}_{2} \mathrm{CO}_{3}$ & - \\
\hline
\end{tabular}


a) Substrate $\mathbf{7 8}(0.100 \mathrm{mmol})$, IndoleBX $21 \quad(0.110 \mathrm{mmol})$, $[\mathrm{Ru}(\mathrm{pCymeneCl})]_{2} 139(4 \mathrm{~mol} \%)$, base $(16 \mathrm{~mol} \%)$ and TFE $(0.1 \mathrm{~m})$ at 60 ${ }^{\circ} \mathrm{C}$. Isolated yield after flash chromatography is given. b) decomposition occurred. c)clean reaction, starting material recovered.<smiles>O=C(O[Na])c1ccccc1</smiles>

80<smiles>NC(=O)C1c2ccccc2Oc2ccccc21</smiles>

82

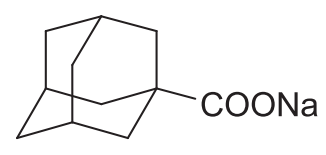

81<smiles>NC(=O)C(C(=O)Nc1ccccc1)c1ccccc1</smiles>

83

Table S12: Screening of the silver(I) additive

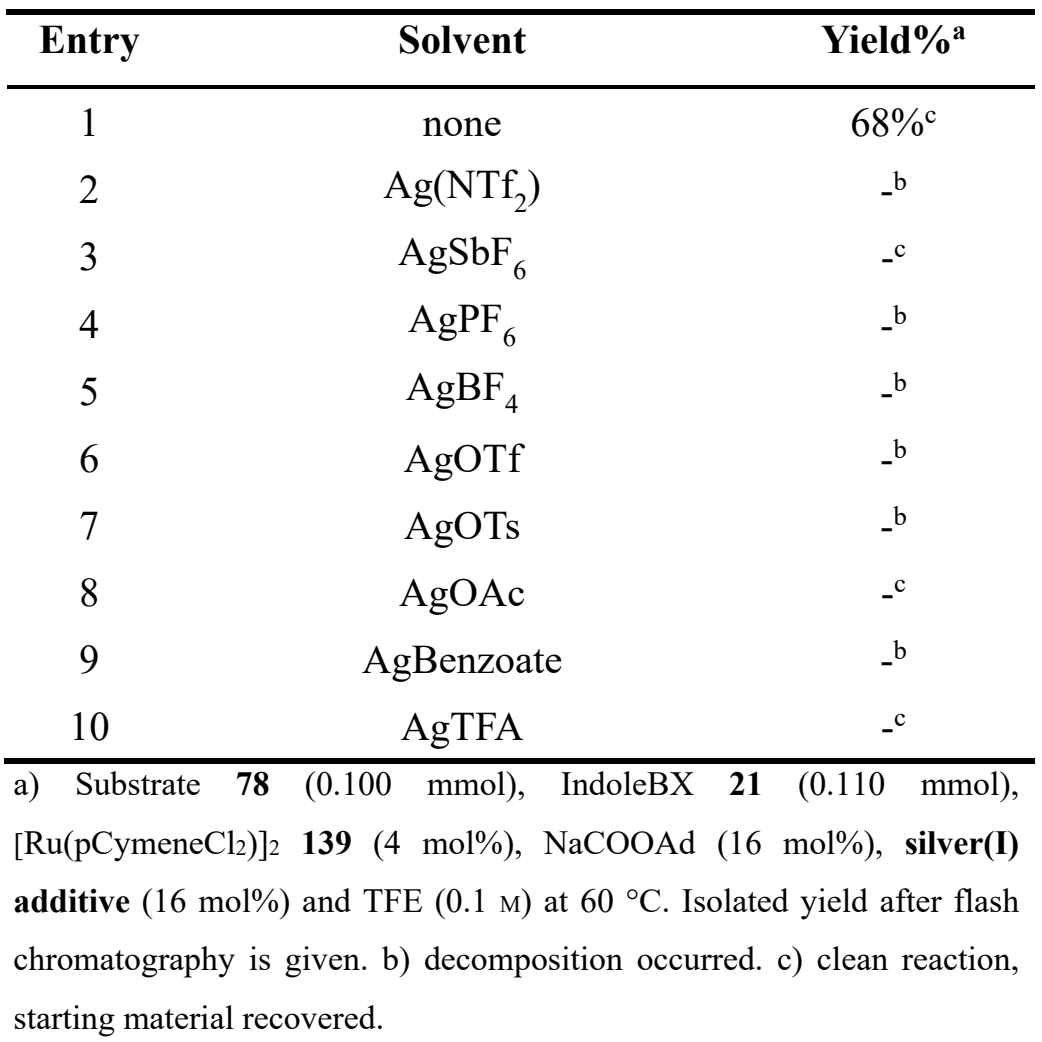




\subsection{Preparation of the Ruthenium Catalyst (84).}<smiles>Cc1cc(C(C)C)cc(C(Cl)(Cl)[R](Cl)(Cl)c2c(C)ccc(C(C)C)c2Cl)c1</smiles>

139

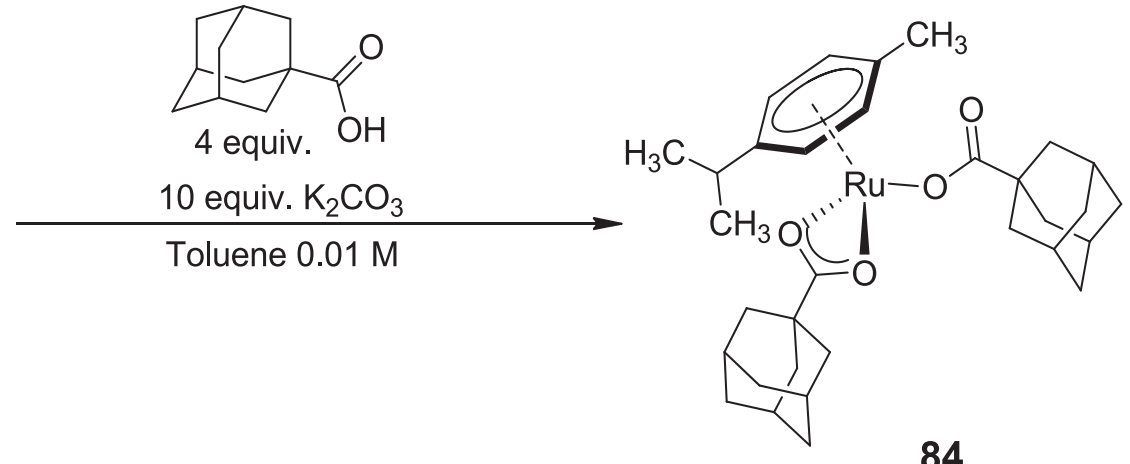

84

Following a reported procedure, ${ }^{2}\left[\mathrm{RuCl}_{2}(\mathrm{p} \text {-cymene })\right]_{2} 139$ (105 mg, $\left.0.163 \mathrm{mmol}\right)$, adamantane-1carboxylic acid (118 mg, $0.652 \mathrm{mmol}, 4.00$ equiv.) and $\mathrm{K}_{2} \mathrm{CO}_{3}$ (225 mg, $1.63 \mathrm{mmol}, 10.0$ equiv.) were suspended in toluene $(16.0 \mathrm{~mL}, 0.01 \mathrm{M})$ under $\mathrm{N}_{2}$. The resulting suspension was stirred for 3 hours at r.t.. The solvent was then removed in vacuo and the residue dissolved in dry $\mathrm{CH}_{2} \mathrm{Cl}_{2}(20$ $\mathrm{mL}$ ). The resulting suspension was filtered under $\mathrm{N}_{2}$ through a short plug of celite. The solvent was removed in vacuo to yield (catalyst) complex 84 (90.0 $\mathrm{mg}, 0.156 \mathrm{mmol}, 96 \%$ yield) as an orange solid. ${ }^{1} \mathbf{H}$ NMR (300 MHz, $\left.\mathrm{CDCl}_{3}\right): \delta 5.70(\mathrm{~d}, J=5.7 \mathrm{~Hz}, 2 \mathrm{H}, \mathrm{Ar} H), 5.49(\mathrm{~d}, J=5.7 \mathrm{~Hz}, 2 \mathrm{H}, \mathrm{Ar} H)$, 2.88 (hept, $\left.J=7.1 \mathrm{~Hz}, 1 \mathrm{H}, \mathrm{ArCH}\left(\mathrm{CH}_{3}\right)_{2}\right), 2.23$ (s, 3H, $\left.\mathrm{ArCH}_{3}\right), 1.92$ (t, $J=3.3 \mathrm{~Hz}, 6 \mathrm{H}$, $\left.\operatorname{ArCH}\left(\mathrm{CH}_{3}\right)_{2}\right), 1.78\left(\mathrm{~s}, 12 \mathrm{H}, \mathrm{AdCH}_{2}\right), 1.63\left(\mathrm{~s}, 12 \mathrm{H}, \mathrm{AdCH}_{2}\right), 1.33$ (d, J=6.9 Hz, 6H, $\left.\mathrm{AdCH}\right) .{ }^{1} \mathrm{H}-$ NMR values are in accordance with the data reported in literature. ${ }^{35}$

[2] L. Ackermann, P. Novák, R. Vicente, N. Hofmann, Angew. Chem. Int. Ed. 2009, 48, 6045-6048. 


\subsection{Scope of the Ru-Catalyzed Indolization via C-H activation.}
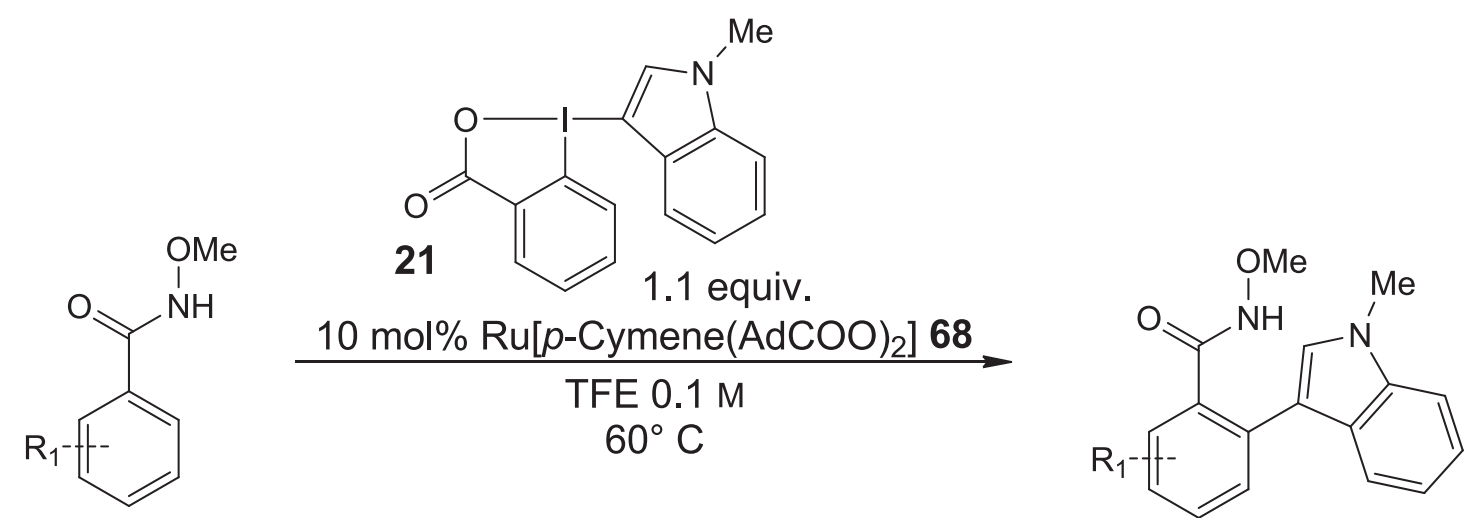

GP6: In a vial, freshly synthetized benzamide 78, 129-138 (50.0 mg, $0.300 \mathrm{mmol}), 1$-(3-1-methyl$1 H$-indole)-1 $H$-1 $1 \lambda_{3}$-benzo[b]iodo-3(2H)-one 21 ( $0.330 \mathrm{mmol}, 1.10$ equiv.) and freshly synthetized Ruthenium complex 139 (18.2 mg, $30.0 \mu \mathrm{mol}, 10 \mathrm{~mol} \%)$, were dissolved in dry TFE ( $3 \mathrm{ml}, 0.1 \mathrm{M})$ under nitrogen. the reaction mixture was degassed (freeze-thaw-pump) and stirred at $60{ }^{\circ} \mathrm{C}$ overnight. It was then allowed to cool down to r.t., washed with a saturated aqueous $\mathrm{NaHCO}_{3}(2 \mathrm{ml})$ and concentrated under reduced pressure. Flash column chromatography (Pentane:EtOAc) afforded the desired products $\mathbf{8 5 - 9 5}$. 
<smiles>CONC(=O)c1ccccc1-c1cn(C)c2ccccc12</smiles>

79

$68 \%$ yield<smiles>CONC(=O)c1ccc(C)cc1-c1cn(C)c2ccccc12</smiles>

85

$34 \%$ yield<smiles>CONC(=O)c1ccc(OC)cc1-c1cn(C)c2ccccc12</smiles>

$91 \%$ yield<smiles>CONC(=O)c1ccc(F)cc1-c1cn(C)c2ccccc12</smiles>

87

$81 \%$ yield<smiles>CONC(=O)c1ccc(Br)cc1-c1cn(C)c2ccccc12</smiles>

88

$84 \%$ yield<smiles>CONC(=O)c1cc(C)ccc1-c1cn(C)c2ccccc12</smiles>

89<smiles>CONC(=O)c1cc(C(F)(F)F)ccc1-c1cn(C)c2ccccc12</smiles>

90<smiles>CONC(=O)c1cc(F)ccc1-c1cn(C)c2ccccc12</smiles>

91 $75 \%$ yield<smiles>CONC(=O)c1cc(Cl)ccc1-c1cn(C)c2ccccc12</smiles>

92

$75 \%$ yield<smiles>CONC(=O)c1cc2c(cc1-c1cn(C)c3ccccc13)OCO2</smiles>

93

$80 \%$ yield<smiles>CONC(=O)c1c(-c2cn(C)c3ccccc23)ccc2ccccc12</smiles>

94

$79 \%$ yield

Figure S11: Scope with Methoxy-amides.

\section{N-Methoxy-2-(1-methyl-1H-indol-3-yl)benzamide (79)}

Starting from N-methoxybenzamide $78(45.3 \mathrm{mg}, 0.300 \mathrm{mmol})$, Nmethoxy-2-(1-methyl-1H-indol-3-yl)benzamide 79 (57.0 mg, $0.203 \mathrm{mmol}$, 68\% yield) was obtained as a yellow oil. Rf: 0.4 (Pentane:EtOAc 2:1). IR v 3209 (w), 3057 (w), 2968 (w), 2934 (m), 2816 (w), 1655 (s), 1599 (w), 1547 (w), 1482 (s), 1464 (m), 1378 (m), 1329 (m), 1223 (m), 1161 (w), 1034 (m), 944 (m), 885 (m). ${ }^{1} \mathbf{H}$ NMR (400 MHz, $\left.\mathrm{CDCl}_{3}\right) \delta 7.98$ (br s, $1 \mathrm{H}$, 
$\left.\mathrm{NHOCH}_{3}\right), 7.74(\mathrm{dd}, J=7.5,5.9 \mathrm{~Hz}, 1 \mathrm{H}, \mathrm{Ar} H), 7.67(\mathrm{~d}, J=7.9 \mathrm{~Hz}, 1 \mathrm{H}$, Indole $H), 7.57$ (dd, $J=$ 7.8, 1.4 Hz, 1H, $\operatorname{Ar} H$ ), $7.52(\mathrm{td}, J=7.5,1.4 \mathrm{~Hz}, 1 \mathrm{H}, \operatorname{Ar} H), 7.38$ (m, 2H, $\operatorname{Ar} H+$ Indole $H$ ), 7.30 (ddd, $J=8.2,6.9,1.1 \mathrm{~Hz}, 1 \mathrm{H}$, Indole $H), 7.24\left(\mathrm{~s}, 1 \mathrm{H}, \mathrm{CH}_{3} \mathrm{NCHC}\right), 7.18$ (ddd, $J=7.9,6.9,1.0 \mathrm{~Hz}, 1 \mathrm{H}$, Indole $H), 3.85\left(\mathrm{~s}, 3 \mathrm{H}, \mathrm{NCH}_{3}\right), 3.46\left(\mathrm{~s}, 3 \mathrm{H}, \mathrm{NHOCH}_{3}\right) .{ }^{13} \mathbf{C} \mathbf{~ N M R}\left(101 \mathrm{MHz}, \mathrm{CDCl}_{3}\right) \delta 168.4,137.0$, $132.5,132.4,130.8,130.7,129.5,128.1,126.8,126.7,122.5,120.3,119.5,113.5,109.6,63.9$, 33.0. HR-ESI-MS $303.1108\left([\mathrm{M}+\mathrm{Na}]^{+}, \mathrm{C}_{17} \mathrm{H}_{16} \mathrm{~N}_{2} \mathrm{NaO}_{2}{ }^{+}\right.$; calc. for 303.1104).

\section{N-Methoxy-4-methyl-2-(1-methyl-1H-indol-3-yl)benzamide (85)}

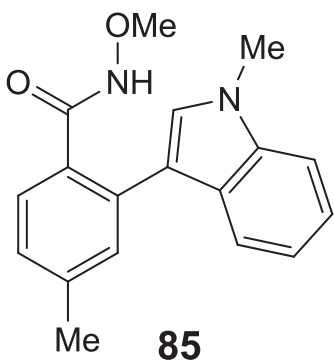

Starting from N-methoxy-4-methylbenzamide 129 (50.0 mg, $0.300 \mathrm{mmol})$, N-methoxy-4-methyl-2-(1-methyl-1H-indol-3-yl)benzamide 85 (30.0 mg, 0.102 mmol, $34 \%$ yield) was obtained as a yellow oil. Rf: 0.44 (Pentane:EtOAc 2:1). IR v 3200 (w), 3047 (w), 2936 (w), 1662 (s), 1615 (m), 1543 (w), 1482 (m), $1370(\mathrm{w}), 1331(\mathrm{w}), 1232(\mathrm{w}), 1160(\mathrm{w}), 1086(\mathrm{w})$, 1040 (w), 1015 (w), 912 (w), 887 (w), 834 (w). ${ }^{1} \mathbf{H}$ NMR (400 MHz, CDCl $\left.{ }_{3}\right)$ $\delta 7.97$ (br s, 1H, $\left.\mathrm{NHOCH}_{3}\right), 7.71-7.64(\mathrm{~m}, 2 \mathrm{H}, \mathrm{ArH}), 7.40-7.34$ (m, 2H, ArH), 7.30 (ddd, $J=$ 8.2, 6.9, $1.2 \mathrm{~Hz}, 1 \mathrm{H}, \mathrm{ArH}$ ), $7.22-7.16$ (m, 3H, $\mathrm{ArH}$ ), 3.85 (s, 3H, $\left.\mathrm{NCH}_{3}\right), 3.44$ (s, 3H, $\mathrm{NHOCH}_{3}$ ), $2.42\left(\mathrm{~s}, 3 \mathrm{H}, \mathrm{ArCH}_{3}\right) .{ }^{13} \mathrm{C}$ NMR $\left(101 \mathrm{MHz}, \mathrm{CDCl}_{3}\right) \delta 168.5,141.1,137.0,132.4,131.4,129.7$, 129.6, 128.0 127.7, 126.8, 122.5, 120.4, 119.6, 113.8, 109.6, 63.8, 33.0, 21.5. HR-ESI-MS $317.1264\left([\mathrm{M}+\mathrm{Na}]^{+}, \mathrm{C}_{18} \mathrm{H}_{18} \mathrm{~N}_{2} \mathrm{NaO}_{2}{ }^{+}\right.$; calc. for 317.1260).

\section{N,4-Dimethoxy-2-(1-methyl-1 H-indol-3-yl)benzamide (86)}

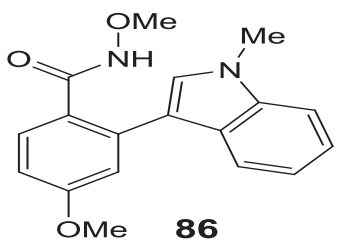

Starting from N,4-dimethoxybenzamide 130 (54.5 mg, $0.300 \mathrm{mmol})$, N,4dimethoxy-2-(1-methyl-1H-indol-3-yl)benzamide 86 (85.0 mg, 0.274 mmol, 91\% yield) was obtained as a yellow oil. Rf: 0.48 (Pentane:EtOAc 2:1). IR $v 3203(\mathrm{w}), 2961(\mathrm{w}), 2936(\mathrm{w}), 2838$ (w), 1661 (s), 1603 (s), 1467 (m), 1330 (m), 1279 (m), 1238 (m), 1214 (m), 1084 (m), 1030 (m), $886(\mathrm{w})$. ${ }^{1} \mathbf{H}$ NMR $\left(400 \mathrm{MHz}, \mathrm{CDCl}_{3}\right) \delta 8.02($ br s, $1 \mathrm{H}, \mathrm{NHOCH}), 7.75(\mathrm{~d}, J=8.6$ $\mathrm{Hz}, 1 \mathrm{H}, \operatorname{Ar} H), 7.66(\mathrm{dd}, J=8.0,1.0 \mathrm{~Hz}, 1 \mathrm{H}, \operatorname{Ar} H), 7.38$ (d, $J=8.3 \mathrm{~Hz}, 1 \mathrm{H}, \operatorname{Ar} H), 7.30$ (ddd, $J=$ 8.1, 7.0, 1.1 Hz, 1H, ArH), 7.22 (s, 1H, NCHC), 7.18 (ddd, J=8.1, 7.0, 1.1 Hz, 1H, ArH), 7.03 (d, $J=2.6 \mathrm{~Hz}, 1 \mathrm{H}, \mathrm{ArH}), 6.92(\mathrm{dd}, J=8.6,2.6 \mathrm{~Hz}, 1 \mathrm{H}, \mathrm{Ar} H), 3.85\left(\mathrm{~s}, 3 \mathrm{H}, \mathrm{NCH}_{3}\right), 3.85\left(\mathrm{~s}, 3 \mathrm{H}, \mathrm{OCH}_{3}\right)$, $3.43\left(\mathrm{~s}, 3 \mathrm{H}, \mathrm{NHOCH}_{3}\right) .{ }^{13} \mathrm{C}$ NMR $\left(101 \mathrm{MHz}, \mathrm{CDCl}_{3}\right) \delta 168.1,161.3,137.0,134.3,131.5,128.0$, 
$126.7,124.8,122.5,120.4,119.6,115.7,113.7,112.5,109.7,63.8,55.4,33.0$. HR-ESI-MS $333.1210\left([\mathrm{M}+\mathrm{Na}]^{+}, \mathrm{C}_{18} \mathrm{H}_{18} \mathrm{~N}_{2} \mathrm{NaO}_{3}{ }^{+}\right.$; calc. for 333.1210).

\section{5-Fluoro-N-methoxy-2-(1-methyl-1H-indol-3-yl)benzamide (87)}

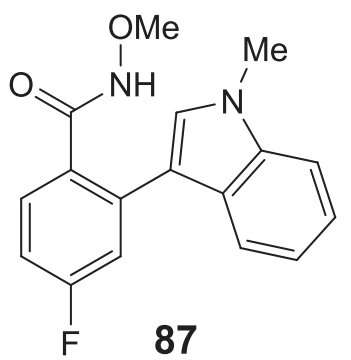

Starting from 4-fluoro-N-methoxybenzamide 131 (50.7 $\mathrm{mg}, 0.300 \mathrm{mmol})$, 4-bromo-N-methoxy-2-(1-methyl-1H-indol-3-yl)benzamide 87 (78.0 mg, 0.243 mmol, $81 \%$ yield) was obtained as a yellow oil. Rf: 0.40 (Pentane:EtOAc 2:1). IR v $3201(\mathrm{w}), 3055$ (w), $2984(\mathrm{w}), 2938(\mathrm{w}), 1932$ (w), 1663 (m), 1551 (w), 1481 (m), 1455 (m), 1374 (m), 1330 (m), 1266 (s), 1245 (m), 1224 (m), 1161 (w), 1052 (m), 943 (w), 829 (s). ${ }^{1}$ H NMR (400 $\left.\mathrm{MHz}, \mathrm{CDCl}_{3}\right) \delta 8.03\left(\mathrm{~s}, 1 \mathrm{H}, \mathrm{NHOCH}_{3}\right), 7.55(\mathrm{~d}, J=7.7 \mathrm{~Hz}, 1 \mathrm{H}, \mathrm{Ar} H), 7.48(\mathrm{~m}, 1 \mathrm{H}, \mathrm{Ar} H), 7.42-$ 7.35 (m, 2H, ArH), 7.33 - 7.27 (m, 2H, ArH), 7.23 (s, 1H, NCHC), 7.17 (ddd, J= 8.0, 7.0, 1.1 Hz, 1H, $\mathrm{ArH}), 3.84\left(\mathrm{~s}, 3 \mathrm{H}, \mathrm{NCH}_{3}\right), 3.31\left(\mathrm{~s}, 3 \mathrm{H}, \mathrm{NHOCH}_{3}\right) .{ }^{13} \mathbf{C}$ NMR $\left(101 \mathrm{MHz}, \mathrm{CDCl}_{3}\right.$; two doublet were not resolved $) \delta 166.6,160.1(\mathrm{~d}, J=247.4 \mathrm{~Hz}), 136.8,135.2,129.2,128.6(\mathrm{~d}, J=8.5 \mathrm{~Hz})$, 127.1, 125.0, 122.5, 120.4, 119.9 (d, $J=2.2 \mathrm{~Hz}), 118.01$ (d, $J=23.3 \mathrm{~Hz}), 109.6,105.9,63.6,33.1$. ${ }^{19}$ F NMR $\left(376 \mathrm{MHz}, \mathrm{CDCl}_{3}\right) \delta$-111.7. HR-ESI-MS $321.1008\left([\mathrm{M}+\mathrm{Na}]^{+}, \mathrm{C}_{17} \mathrm{H}_{15} \mathrm{FN}_{2} \mathrm{NaO}_{2}{ }^{+}\right.$; calc. for 321.1010).

\section{4-Bromo-N-methoxy-2-(1-methyl-1H-indol-3-yl)benzamide (88)}

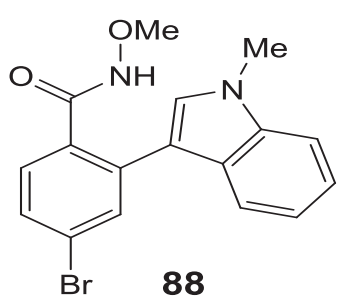

Starting from 4-bromo-N-methoxybenzamide 132 (69.0 mg, $0.300 \mathrm{mmol})$, 4-bromo-N-methoxy-2-(1-methyl-1H-indol-3-yl)benzamide 88 (91.0 mg, $0.253 \mathrm{mmol}, 84 \%$ yield) was obtained as an orange oil. Rf: 0.35 (Pentane:EtOAc 2:1). IR v $3186(\mathrm{w}), 3063$ (w), 2934 (w), 1656 (s), 1605 (s), $1580(\mathrm{~m}), 1480(\mathrm{~s}), 1364(\mathrm{w}), 1331$ (m), 1265 (s), 1195 (m), $1082(\mathrm{w})$, 1037 (m), 986 (w), 939 (w), 887 (m), 826 (m). ${ }^{1} \mathbf{H}$ NMR (400 MHz, $\mathrm{CDCl}_{3}$ ) $\delta 8.04\left(\mathrm{br} \mathrm{s}, 1 \mathrm{H}, \mathrm{NHOCH}_{3}\right), 7.75(\mathrm{~m}, 1 \mathrm{H}, \mathrm{ArH}), 7.67$ (d, J=8.0 Hz, 1H, ArH), 7.39 (d, J= 8.2 Hz, 1H, $\operatorname{Ar} H), 7.33(\mathrm{~m}, 1 \mathrm{H}, \operatorname{Ar} H), 7.28-7.24(\mathrm{~m}, 2 \mathrm{H}, \operatorname{Ar} H), 7.21$ (m, 1H, $\operatorname{Ar} H), 7.07(\mathrm{td}, J=8.3,2.6$ $\mathrm{Hz}, 1 \mathrm{H}, \mathrm{Ar} H), 3.85(\mathrm{~s}, 3 \mathrm{H}, \mathrm{NCH}), 3.46\left(\mathrm{~s}, 3 \mathrm{H}, \mathrm{NHOCH}_{3}\right) .{ }^{13} \mathbf{C} \mathbf{N M R}\left(101 \mathrm{MHz}, \mathrm{CDCl}_{3}\right) \delta 167.4$, 137.0, 134.6, 133.3 131.2, 129.8, 128.4, 126.4, 125.2, 122.8, 120.7, 119.3, 112.3, 109.8, 63.9, 33.1 
(one Carbon signal not resolved). HR-ESI-MS $381.0204\left([\mathrm{M}+\mathrm{Na}]^{+}, \mathrm{C}_{17} \mathrm{H}_{15}{ }^{79} \mathrm{BrN}_{2} \mathrm{NaO}_{2}{ }^{+}\right.$; calc. for 381.0209).

\section{N-Methoxy-5-methyl-2-(1-methyl-1H-indol-3-yl)benzamide (89)}<smiles>CONC(=O)c1cc(C)ccc1-c1cn(C)c2ccccc12</smiles>

89

Starting from N-methoxy-3-methylbenzamide $133(50.0 \mathrm{mg}, 0.300$ mmol), N-methoxy-5-methyl-2-(1-methyl-1H-indol-3-yl)benzamide 89 (44.0 mg, $0.149 \mathrm{mmol}, 50 \%$ yield) was obtained as a yellow oil. Rf: 0.40 (Pentane:EtOAc 2:1). IR v $3181(\mathrm{w}), 2932(\mathrm{w}), 1713$ (s), 1660 (s), 1606 (m), 1538 (w), $1466(\mathrm{w}), 1437$ (w), 1289 (m), 1262 (s), 1248 (s), 1162 (w), 1128 (m), 1107 (m), 1038 (w). ${ }^{1} \mathbf{H}$ NMR (400 MHz, $\left.\mathrm{CD}_{2} \mathrm{Cl}_{2}\right)$ $\delta 8.27(\mathrm{~s}, 1 \mathrm{H}, \mathrm{Ar} H), 8.24\left(\mathrm{~s}, 1 \mathrm{H}, \mathrm{NHOCH}_{3}\right), 8.13(\mathrm{dd}, J=8.1,1.9 \mathrm{~Hz}, 1 \mathrm{H}, \mathrm{Ar} H), 7.67$ (dd, $J=9.9$, $8.0 \mathrm{~Hz}, 2 \mathrm{H}, \operatorname{Ar} H), 7.41$ (dt, $J=8.3,0.9 \mathrm{~Hz}, 1 \mathrm{H}, \operatorname{Ar} H), 7.34$ (s, 1H, $\operatorname{Ar} H), 7.29$ (ddd, $J=8.2,7.0$, $1.1 \mathrm{~Hz}, 1 \mathrm{H}, \mathrm{Ar} H), 7.18(\mathrm{ddd}, J=8.0,7.0,1.1 \mathrm{~Hz}, 1 \mathrm{H}, \mathrm{Ar} H), 3.92(\mathrm{~s}, 3 \mathrm{H}, \mathrm{NCH}), 3.85\left(\mathrm{~s}, 3 \mathrm{H}, \mathrm{CH}_{3}\right)$, 3.49 (s, 3H, $\left.\mathrm{NHOCH}_{3}\right) .{ }^{13} \mathrm{C}$ NMR $\left(101 \mathrm{MHz}, \mathrm{CD}_{2} \mathrm{Cl}_{2}\right) \delta 166.7,138.2,137.8,133.1,131.8,131.2$, $131.0,129.5,128.6,127.0,123.1,121.0,119.9,113.3,110.4,64.3,52.7,33.6$. HR-ESI-MS $317.1265\left([\mathrm{M}+\mathrm{Na}]^{+}, \mathrm{C}_{18} \mathrm{H}_{18} \mathrm{~N}_{2} \mathrm{NaO}_{2}{ }^{+}\right.$calc. for 317.1260$)$.

\section{N-Methoxy-2-(1-methyl-1H-indol-3-yl)-5-(trifluoromethyl)benzamide (90)}<smiles>CONC(=O)c1cc(C(F)(F)F)ccc1-c1cn(C)c2ccccc12</smiles>

90

Starting from N-methoxy-3-(trifluoromethyl)benzamide 134 (65.7 mg, $0.300 \quad$ mmol), N-methoxy-2-(1-methyl-1H-indol-3-yl)-5(trifluoromethyl)benzamide 90 (63.0 $\mathrm{mg}, 0.181 \mathrm{mmol}, 60 \%$ yield) was obtained as a colorless oil. Rf: 0.37 (Pentane:EtOAc 2:1). IR $v 3187$ (w), $2978(\mathrm{w}), 2935(\mathrm{w}), 1657(\mathrm{~m}), 1617(\mathrm{w}), 1549(\mathrm{w}), 1469(\mathrm{w}), 1331$ (s), $1274(\mathrm{w}), 1173(\mathrm{~m}), 1159(\mathrm{~m}), 1127(\mathrm{~s}), 1092(\mathrm{~m}), 947(\mathrm{w}), 911$ (w), 849 (w). ${ }^{1} \mathbf{H}$ NMR (400 MHz, $\left.\mathrm{CDCl}_{3}\right) \delta 8.00$ (br s, 1H, NHOCH 3$), 7.91(\mathrm{~s}, 1 \mathrm{H}, \mathrm{ArH}), 7.70$ $7.62(\mathrm{~m}, 2 \mathrm{H}, \mathrm{ArH}), 7.59$ (d, J=8.0 Hz, 1H, ArH), 7.33 (m, 1H, ArH), 7.27 (m, 1H, ArH), 7.24 (s, $1 \mathrm{H}, \mathrm{NCHC}), 7.14$ (ddd, $J=8.0,6.9,1.1 \mathrm{~Hz}, 1 \mathrm{H}, \mathrm{ArH}), 3.79$ (s, 3H, $\left.\mathrm{NCH}_{3}\right), 3.45$ (s, 3H, $\mathrm{NHOCH}_{3}$ ). ${ }^{13} \mathrm{C}$ NMR $\left(101 \mathrm{MHz}, \mathrm{CDCl}_{3}\right) \delta 167.1,137.1,136.4,132.6,130.9,128.8,128.7,127.3,126.7$, $126.4,123.80\left(\mathrm{q}, J=272.1 \mathrm{~Hz}, C F_{3}\right), 122.8,120.8,119.2,112.2,109.9,64.1,33.1 .{ }^{19} \mathbf{F}$ NMR (376 $\left.\mathrm{MHz}, \mathrm{CDCl}_{3}\right) \delta$-62.5. HR-ESI-MS $371.0979\left([\mathrm{M}+\mathrm{Na}]^{+}, \mathrm{C}_{18} \mathrm{H}_{15} \mathrm{~F}_{3} \mathrm{~N}_{2} \mathrm{NaO}_{2}{ }^{+}\right.$calc. for 371.0978). 


\section{5-Fluoro-N-methoxy-2-(1-methyl-1H-indol-3-yl)benzamide (91)}<smiles>CONC(=O)c1cc(F)ccc1-c1cn(C)c2ccccc12</smiles>

91

Starting from 3-fluoro-N-methoxybenzamide 135 (50.7 mg, 0.300 mmol), 4-bromo-N-methoxy-2-(1-methyl-1H-indol-3-yl)benzamide 91 ( $84.0 \mathrm{mg}, 0.225 \mathrm{mmol}, 75 \%$ yield) was obtained as a yellow oil. Rf: 0.38 (Pentane:EtOAc 2:1). IR v $3179(\mathrm{w}), 3055$ (w), 2932 (m), $2853(\mathrm{w}), 1662$ (s), $1586(\mathrm{~m}), 1550(\mathrm{w}), 1479$ (s), 1329 (w), $1256(\mathrm{w}), 1222$ (w), 1163 (w), 1089 (m), 1038 (m), 956 (w), 911 (m), 882 (m), 824 (w). ${ }^{\mathbf{1}}$ H NMR $\left(400 \mathrm{MHz}, \mathrm{CDCl}_{3}\right) \delta 8.00$ (br s, $\left.1 \mathrm{H}, \mathrm{NHOCH}_{3}\right), 7.72(\mathrm{~d}, J=2.0 \mathrm{~Hz}, 1 \mathrm{H}, \mathrm{Ar} H), 7.64(\mathrm{t}, J=9.1 \mathrm{~Hz}$, 2H, $\operatorname{Ar} H), 7.52(\mathrm{dd}, J=8.2,2.0 \mathrm{~Hz}, 1 \mathrm{H}, \operatorname{Ar} H), 7.40(\mathrm{~m}, 1 \mathrm{H}, \operatorname{Ar} H), 7.32(\mathrm{dd}, J=7.0,1.2 \mathrm{~Hz}, 1 \mathrm{H}$, $\operatorname{ArH}), 7.25$ (s, 1H, NCHC), 7.21 (ddd, $J=8.0,6.9,1.1 \mathrm{~Hz}, 1 \mathrm{H}, \mathrm{ArH}), 3.85$ (s, 3H, NCH3), 3.45 (s, $\left.3 \mathrm{H}, \mathrm{NHOCH}_{3}\right) .{ }^{13} \mathbf{C}$ NMR $\left(101 \mathrm{MHz}, \mathrm{CDCl}_{3}\right) \delta 167.6,163.8(\mathrm{~d}, J=250.9 \mathrm{~Hz}), 137.0,135.4,135.3$ $(\mathrm{d}, J=9.4 \mathrm{~Hz}), 131.8(\mathrm{~d}, J=9.5 \mathrm{~Hz}), 128.4,128.3,126.4,122.7,120.7,117.10(\mathrm{~d}, J=21.5 \mathrm{~Hz})$, $113.79(\mathrm{~d}, J=21.9 \mathrm{~Hz}), 112.5,109.8,63.9,33.1 .{ }^{19} \mathbf{F}$ NMR $\left(376 \mathrm{MHz}, \mathrm{CDCl}_{3}\right) \delta$-109.3. HR-ESIMS $321.1011\left([\mathrm{M}+\mathrm{Na}]^{+}, \mathrm{C}_{17} \mathrm{H}_{15} \mathrm{FN}_{2} \mathrm{NaO}_{2}{ }^{+}\right.$calc. for 321.1010$)$.

5-Chloro-N-methoxy-2-(1-methyl-1H-indol-3-yl)benzamide (92)<smiles>CONC(=O)c1cc(Cl)ccc1-c1cn(C)c2ccccc12</smiles>

92

Starting from 3-chloro-N-methoxybenzamide $136(55.7 \mathrm{mg}, 0.300$ mmol), N-methoxy-2-(1-methyl-1H-indol-3-yl)-5(trifluoromethyl)benzamide 92 (70.9 $\mathrm{mg}, 0.225 \mathrm{mmol}, 75 \%$ yield) was obtained as a yellow oil. Rf: 0.35 (Pentane:EtOAc 2:1). IR $v 3185(\mathrm{w})$, $3058(\mathrm{w}), 2931(\mathrm{~m}), 2852(\mathrm{w}), 1656(\mathrm{~s}), 1543(\mathrm{w}), 1482(\mathrm{~m}), 1466(\mathrm{~m})$, $1374(\mathrm{w}), 1330(\mathrm{w}), 1256(\mathrm{w}), 1163(\mathrm{w}), 1100(\mathrm{~m}), 1041(\mathrm{w}), 943(\mathrm{~m})$, 824 (w). ${ }^{1} \mathbf{H}$ NMR (400 MHz, $\left.\mathrm{CDCl}_{3}\right) \delta 7.81$ (br s, $1 \mathrm{H}, \mathrm{NHOCH}$ ), 7.64 (dd, $J=8.0,1.3 \mathrm{~Hz}, 1 \mathrm{H}$, $\operatorname{Ar} H), 7.60$ (d, $J=7.7 \mathrm{~Hz}, 1 \mathrm{H}, \operatorname{Ar} H), 7.45-7.37$ (m, 2H, $\operatorname{Ar} H), 7.35(\mathrm{~d}, J=7.9 \mathrm{~Hz}, 1 \mathrm{H}, \operatorname{Ar} H), 7.29$ (m, 1H, ArH), 7.19 (s, 1H, NCHC), 7.15 (t, J=7.5 Hz, 1H, ArH), 3.87 (s, 3H, NCH ), 3.15 (s, 3H, $\left.\mathrm{NHOCH}_{3}\right) .{ }^{13} \mathrm{C}$ NMR $\left(101 \mathrm{MHz}, \mathrm{CDCl}_{3}\right) \delta 166.9,137.0,133.6,132.7,132.0,131.1,130.9,129.5$, 128.2, 126.6, 122.7, 120.6, 119.3, 112.3, 109.8, 64.0, 33.1. HR-ESI-MS 337.0720 ([M+Na $]^{+}$, $\mathrm{C}_{17} \mathrm{H}_{15} \mathrm{ClN}_{2} \mathrm{NaO}_{2}{ }^{+}$calc. for 337.0714). 


\section{N-Methoxy-6-(1-methyl-1H-indol-3-yl)benzo[d][1,3]dioxole-5-carboxamide (93)}

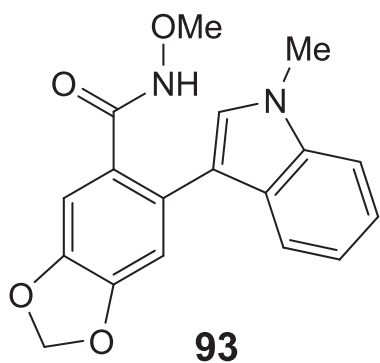

Starting from N-methoxybenzo[d][1,3]dioxole-5-carboxamide 137 (58.6 mg, $\quad 0.300 \quad$ mmol), N-methoxy-6-(1-methyl-1H-indol-3yl)benzo[d][1,3]dioxole-5-carboxamide 93 (78.0 mg, $0.240 \mathrm{mmol}, 80 \%$ yield) was obtained as a white oil. Rf: 0.48 (Pentane:EtOAc 2:1). IR v $3191(w), 2967$ (w), 2934 (w), $2899(\mathrm{w}), 1656$ (m), 1628 (m), $1480(\mathrm{~m})$, 1448 (s), 1374 (w), 1340 (m), 1250 (s), 1224 (w), 1132 (w), 1040 (s), 1017 (w), 929 (m), 833 (w). ${ }^{1} \mathbf{H}$ NMR (400 MHz, $\mathrm{CD}_{2} \mathrm{Cl}_{2}$ ) $\delta 7.49$ (d, $\left.J=8.0 \mathrm{~Hz}, 1 \mathrm{H}, \mathrm{ArH}\right), 7.40$ (d, $J=8.3 \mathrm{~Hz}, 1 \mathrm{H}$, Indole $H$ ), $7.33-7.25$ (m, 3H, Indole $H$ ), 7.14 (ddd, $J=8.0,6.9,1.0 \mathrm{~Hz}, 1 \mathrm{H}$, $\operatorname{Ar} H), 6.85(\mathrm{~d}, J=8.1 \mathrm{~Hz}, 1 \mathrm{H}$, Indole $H), 6.01\left(\mathrm{~s}, 2 \mathrm{H}, \mathrm{OCH}_{2} \mathrm{O}\right), 3.84(\mathrm{~s}, 3 \mathrm{H}, \mathrm{NCH}), 3.35(\mathrm{~s}, 3 \mathrm{H}$, $\left.\mathrm{NHOCH}_{3}\right)$. (NHOMe proton present at $\left.8.2 \mathrm{ppm}\right){ }^{13} \mathbf{C} \mathbf{~ N M R}\left(101 \mathrm{MHz}, \mathrm{CD}_{2} \mathrm{Cl}_{2}\right.$; the signals of two aromatic carbons were not resolved) $\delta 166.8,149.5,146.1,137.0,129.4,127.1,126.9,124.1,122.4$, $120.2,115.2,109.8,107.0,106.8,101.7,63.6,33.1$.

\section{N-Methoxy-2-(1-methyl-1H-indol-3-yl)-1-naphthamide (94)}<smiles>CONC(=O)c1c(-c2cn(C)c3ccccc23)ccc2ccccc12</smiles>

94

Starting from N-methoxy-1-naphthamide 138 (60.4 mg, $0.300 \mathrm{mmol})$, N-methoxy-2-(1-methyl-1H-indol-3-yl)-1-naphthamide 94 (78.0 mg, $0.236 \mathrm{mmol}, 79 \%$ yield) was obtained as a colorless oil. Rf: 0.35 (Pentane:EtOAc 2:1). IR v $3186(\mathrm{w}), 3056(\mathrm{w}), 2958$ (w), 2929 (m), 2854 (w), 1651 (s), 1615 (m), 1545 (w), 1479 (m), $1384(\mathrm{w}), 1339$ (w), $1264(\mathrm{w}), 1230(\mathrm{w}), 1134(\mathrm{w}), 1101(\mathrm{w}), 1074(\mathrm{~m}), 1019(\mathrm{~m}), 892(\mathrm{w})$,

821 (s). ${ }^{1} \mathbf{H}$ NMR $\left(400 \mathrm{MHz}, \mathrm{CDCl}_{3}\right) \delta 8.06(\mathrm{~d}, J=8.5 \mathrm{~Hz}, 1 \mathrm{H}, \mathrm{ArH}), 8.00-7.95(\mathrm{~m}, 2 \mathrm{H}, \mathrm{Ar} H+$ $\left.\mathrm{NHOCH}_{3}\right), 7.89$ (m, 1H, ArH), 7.80 (t, $\left.J=8.6 \mathrm{~Hz}, 2 \mathrm{H}, \mathrm{Ar} H\right), 7.58$ (ddd, $J=8.4,6.8,1.4 \mathrm{~Hz}, 1 \mathrm{H}$, $\operatorname{Ar} H), 7.52$ (ddd, $J=8.1,6.9,1.3 \mathrm{~Hz}, 1 \mathrm{H}, \operatorname{Ar} H), 7.41(\mathrm{~d}, J=9.7 \mathrm{~Hz}, 2 \mathrm{H}, \operatorname{Ar} H), 7.32(\mathrm{~m}, 1 \mathrm{H}, \operatorname{Ar} H)$, $7.22(\mathrm{~m}, 1 \mathrm{H}, \mathrm{ArH}), 3.86\left(\mathrm{~s}, 3 \mathrm{H}, \mathrm{NCH}_{3}\right), 3.66\left(\mathrm{~s}, 3 \mathrm{H}, \mathrm{NHOCH}_{3}\right) .{ }^{13} \mathbf{C} \mathbf{N M R}\left(101 \mathrm{MHz}, \mathrm{CDCl}_{3}\right) \delta$ $168.3,137.1,131.8,131.3,131.1,130.0,128.9,128.5,128.0,127.6,127.4,126.9,126.0,124.8$, 122.3, 120.2, 119.4, 113.1, 109.8, 64.0, 33.0. HR-ESI-MS 353.1256 ([M+Na] $]^{+}, \mathrm{C}_{21} \mathrm{H}_{18} \mathrm{~N}_{2} \mathrm{NaO}_{2}{ }^{+}$ calc. for 353.1260$)$. 


\section{Crystal Structure and DSC Measurements.}

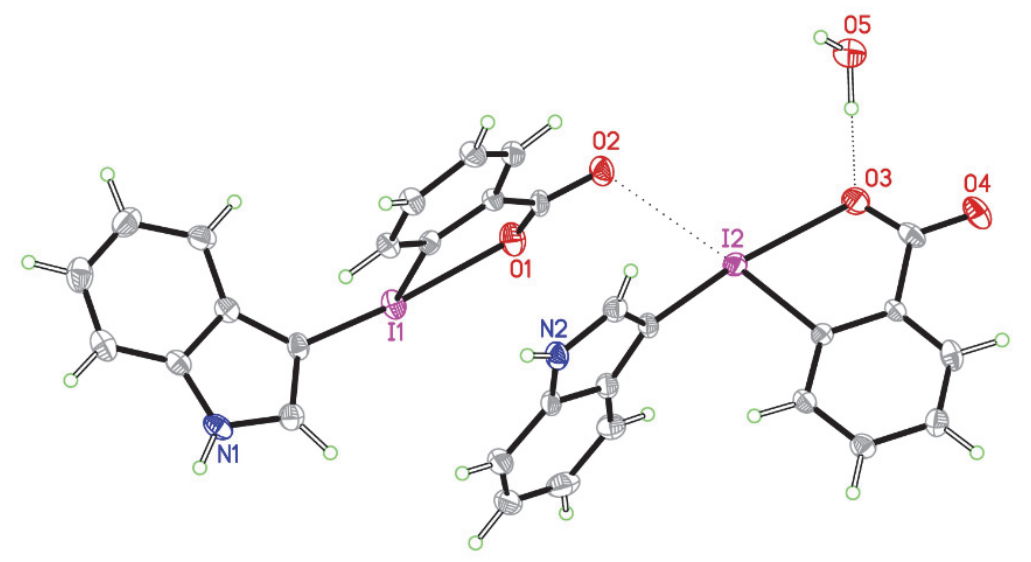

A single crystal was grown by slow diffusion of the solution of 25 in $\mathrm{MeOD} / \mathrm{CCl}_{4}$ mixture. Supplementary crystallographic data for this compound have been deposited at Cambridge Crystallographic Data Centre (1540821) and can be obtained free of charge via www.ccdc.cam.ac.uk/data_request/cif.

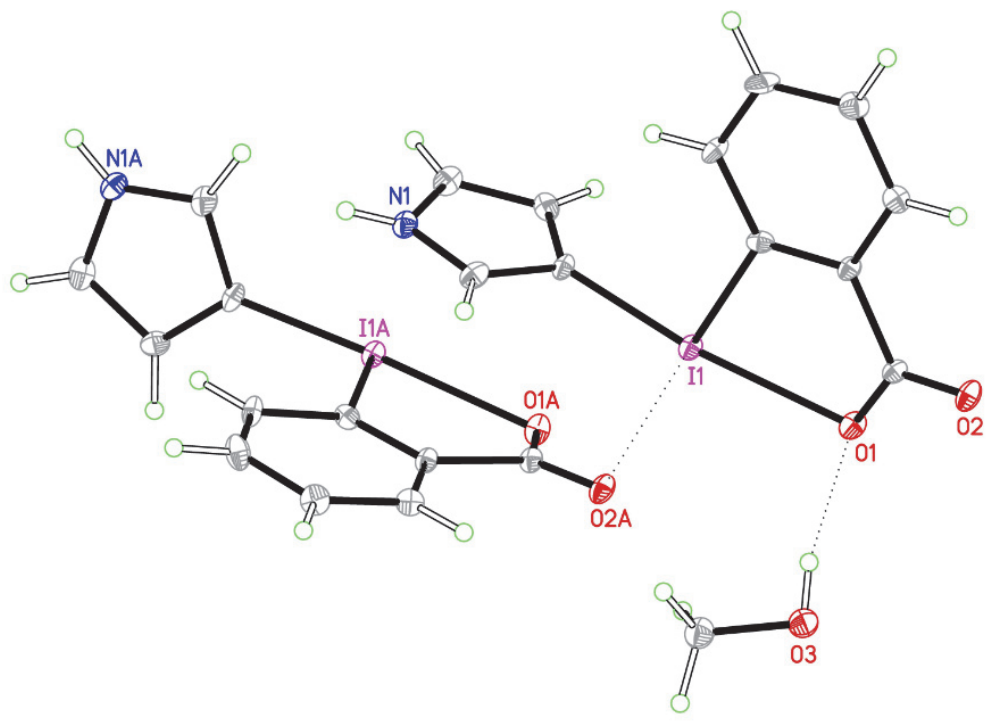

A single crystal was grown by slow diffusion of the solution of 37 in $\mathrm{MeOD} / \mathrm{CCl}_{4}$ mixture. Supplementary crystallographic data for this compound have been deposited at Cambridge Crystallographic Data Centre (1541174) and can be obtained free of charge via www.ccdc.cam.ac.uk/data_request/cif. 
DSC measurements of compound 21

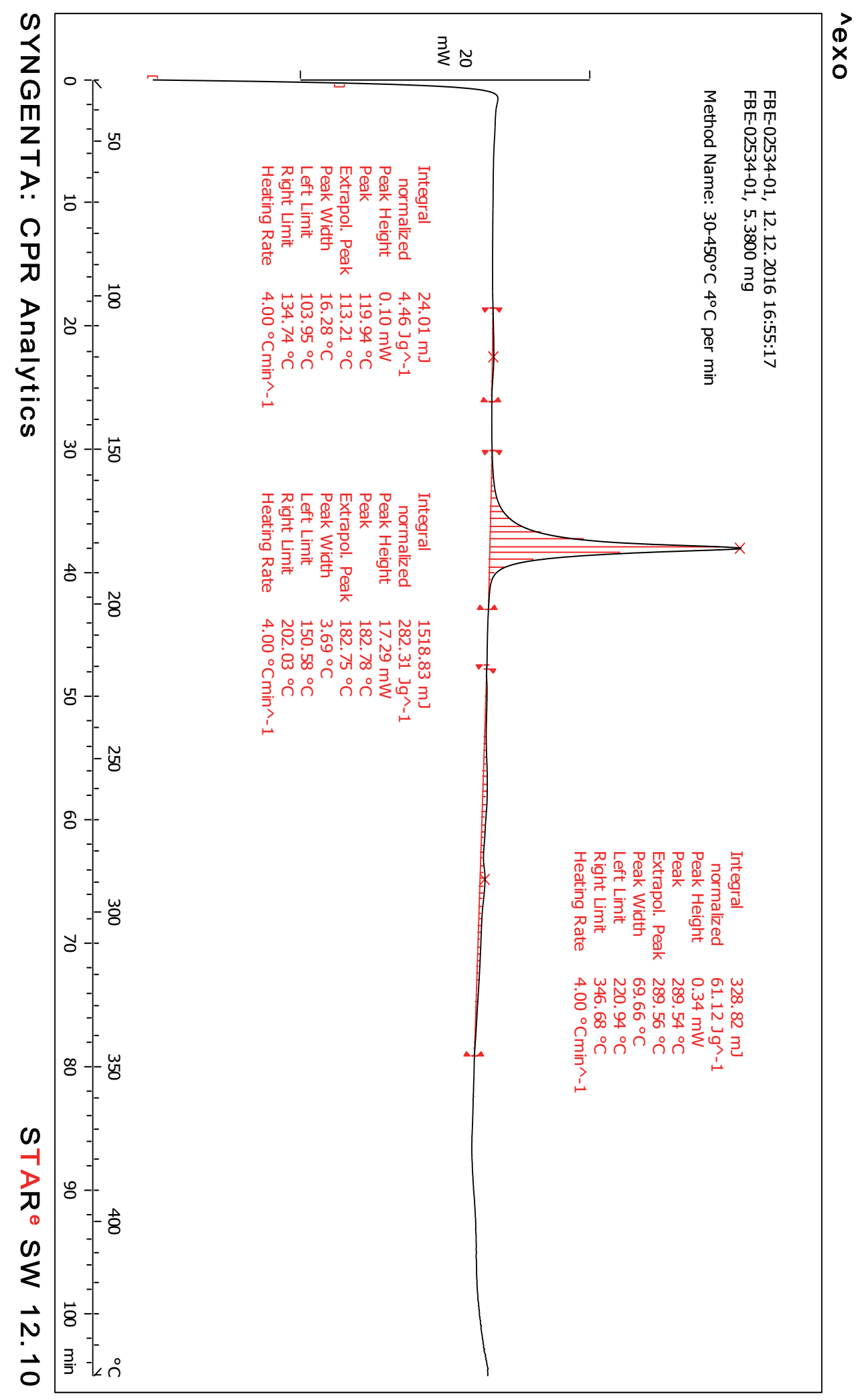


DSC measurements of compound 35a

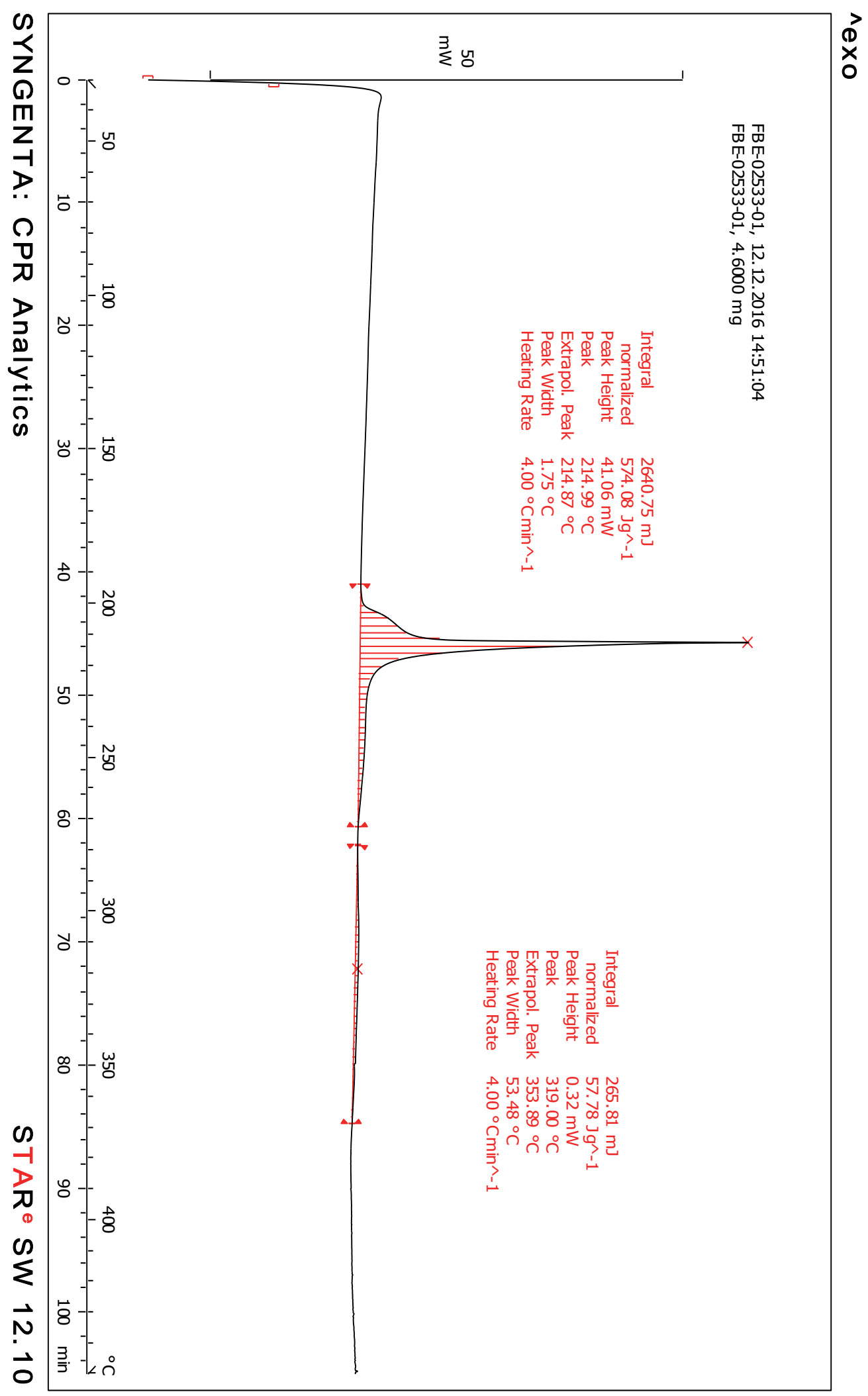


DSC measurements of compound $35 b$

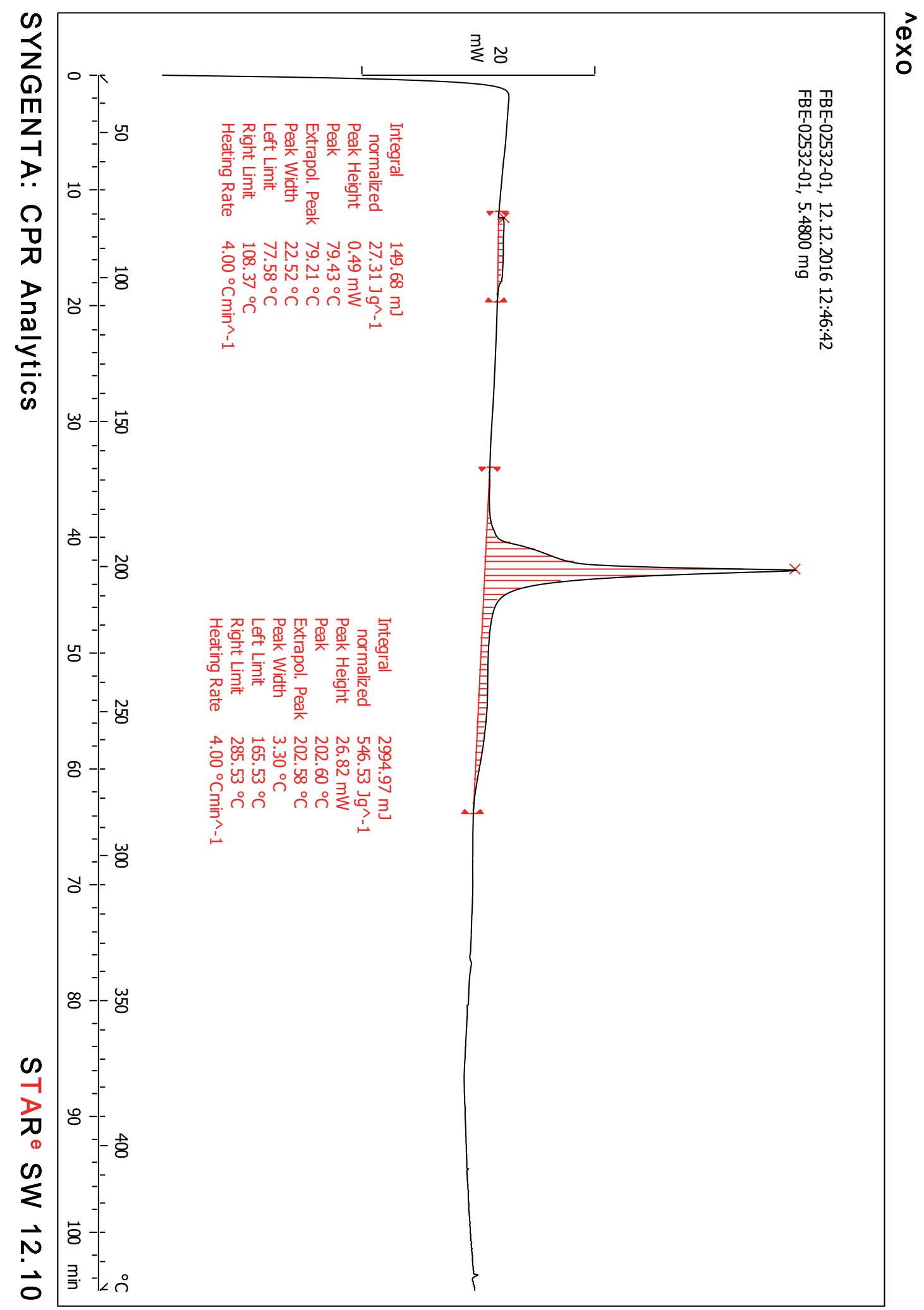




\section{Bibliography}

[1] P. Caramenti, S. Nicolai, J. Waser, 'Indole- and Pyrrole-BX: Bench-Stable Hypervalent Iodine Reagents for Heterocycle Umpolung', Chem. Eur. J. 2017 DOI: 10.1002/chem. 201703723

[2] A. T. Parsons, S. L. Buchwald, 'Copper-Catalyzed Trifluoromethylation of Unactivated Olefins', Angew. Chem., Int. Ed. 2011, 50, 9120-9123.

[3] P. Eisenberger, S. Gischig, A. Togni, 'Novel 10-I-3 Hypervalent Iodine-Based Compounds for Electrophilic Trifluoromethylation', Chem. Eur. J. 2006, 12, 2579-2586.

[4] K. Jia, Y. Pan, Y. Chen, 'Selective Carbonyl-C(sp3) Bond Cleavage To Construct Ynamides, Ynoates, and Ynones by Photoredox Catalysis', Angew. Chem., Int. Ed. 2017, $56,2478-2481$.

[5] M. Iinuma, K. Moriyama, H. Togo, 'Oxidation of Alcohols to Aldehydes or Ketones with 1Acetoxy-1,2-benziodoxole-3(1H)-one Derivatives', Eur. J. Org. Chem. 2014, 2014, 772780.

[6] E. F. Perozzi, R. S. Michalak, G. D. Figuly, W. H. Stevenson, D. Dess, M. R. Ross, J. C. Martin, 'Directed dilithiation of hexafluorocumyl alcohol - formation of a reagent for the facile introduction of a stabilizing bidentate ligand in compounds of hypervalent sulfur (10S-4), phosphorus (10-P-5), silicon (10-Si-5), and iodine (10-I-3)', J. Org. Chem. 1981, 46, 1049-1053.

[7] V. V Zhdankin, A. P. Krasutsky, C. J. Kuehl, A. J. Simonsen, J. K. Woodward, B. Mismash, J. T. Bolz, 'Preparation, X-ray Crystal Structure, and Chemistry of Stable AzidoiodinanesDerivatives of Benziodoxole', J. Am. Chem. Soc. 1996, 118, 5192-5197.

[8] G. L. Tolnai, S. Ganss, J. P. Brand, J. Waser, 'C2-Selective Direct Alkynylation of Indoles', Org. Lett. 2013, 15, 112-115.

[9] Y. Li, J. Waser, 'Platinum-Catalyzed Domino Reaction with Benziodoxole Reagents for Accessing Benzene-Alkynylated Indoles', Angew. Chemie Int. Ed. 2015, 54, 5438-5442.

[10] J. P. Brand, J. Charpentier, J. Waser, 'Direct Alkynylation of Indole and Pyrrole Heterocycles', Angew. Chemie Int. Ed. 2009, 48, 9346-9349.

[11] A. F. G. Maier, S. Tussing, T. Schneider, U. Flörke, Z.-W. Qu, S. Grimme, J. Paradies, 'Frustrated Lewis Pair Catalyzed Dehydrogenative Oxidation of Indolines and Other Heterocycles', Angew. Chemie Int. Ed. 2016, 55, 12219-12223.

[12] S. Islam, I. Larrosa, '“On Water", Phosphine-Free Palladium-Catalyzed Room Temperature C $\square$ H Arylation of Indoles', Chem. Eur. J. 2013, 19, 15093-15096.

[13] D. Saha, R. Ghosh, A. Sarkar, '3-Indolylphosphines as ligand for palladium in SuzukiMiyaura coupling reaction of chloroarenes: substituent effects', Tetrahedron 2013, 69, 3951-3960.

[14] W. C. Guida, D. J. Mathre, 'Phase-transfer alkylation of heterocycles in the presence of 18- 
crown-6 and potassium tert-butoxide', J. Org. Chem. 1980, 45, 3172-3176.

[15] H. A. Kerchner, J. Montgomery, 'Synthesis of Secondary and Tertiary Alkylboranes via Formal Hydroboration of Terminal and 1,1-Disubstituted Alkenes', Org. Lett. 2016, 18, $5760-5763$.

[16] J. W. Bode, E. M. Carreira, 'Stereoselective Syntheses of Epothilones A and B via Nitrile Oxide Cycloadditions and Related Studies', J. Org. Chem. 2001, 66, 6410-6424.

[17] Y. R. Jorapur, J. M. Jeong, D. Y. Chi, 'Potassium carbonate as a base for the N-alkylation of indole and pyrrole in ionic liquids', Tetrahedron Lett. 2006, 47, 2435-2438.

[18] 'See the Spectra section'

[19] B. S. Lane, M. A. Brown, D. Sames, 'Direct Palladium-Catalyzed C-2 and C-3 Arylation of Indoles: A Mechanistic Rationale for Regioselectivity', J. Am. Chem. Soc. 2005, 127, 80508057.

[20] B. Y. Karele, L. é. Treigute, S. V Kalnin', I. P. Grinberga, O. Y. Neiland, 'Iodonium derivatives of heterocyclic compounds', Chem. Heterocycl. Compd. 1974, 10, 189-192.

[21] H. Mizuno, J. Takaya, N. Iwasawa, 'Rhodium(I)-Catalyzed Direct Carboxylation of Arenes with $\mathrm{CO} 2$ via Chelation-Assisted $\mathrm{C}-\mathrm{H}$ Bond Activation', J. Am. Chem. Soc. 2011, 133, $1251-1253$.

[22] M. Nishino, K. Hirano, T. Satoh, M. Miura, 'Copper-Mediated and Copper-Catalyzed CrossCoupling of Indoles and 1,3-Azoles: Double C-H Activation', Angew. Chem., Int. Ed. 2012, 51, 6993-6997.

[23] L. Ackermann, A. V Lygin, 'Ruthenium-Catalyzed Direct C-H Bond Arylations of Heteroarenes', Org. Lett. 2011, 13, 3332-3335.

[24] M. A. Ali, X. Yao, H. Sun, H. Lu, '[RhCp*C12]2-Catalyzed Directed N-Boc Amidation of Arenes “on Water", Org. Lett. 2015, 17, 1513-1516.

[25] M. W. Hooper, M. Utsunomiya, J. F. Hartwig, 'Scope and Mechanism of PalladiumCatalyzed Amination of Five-Membered Heterocyclic Halides', J. Org. Chem. 2003, 68, 2861-2873.

[26] K. T. Neumann, S. R. Laursen, A. T. Lindhardt, B. Bang-Andersen, T. Skrydstrup, 'Palladium-Catalyzed Carbonylative Sonogashira Coupling of Aryl Bromides Using Near Stoichiometric Carbon Monoxide', Org. Lett. 2014, 16, 2216-2219.

[27] D. S. G. Spinella A. Izzo I., 'A Pd-Mediated Approach to the Synthesis of an Unusual $\beta$ Hydroxy-tryptophan Amino Acid Constituent of Cyclomarin A', 2006, 1319-1322.

[28] B. A. Witulski Javier Ramon; Alayrac, Carole; Arnautu, Anca; Collot, Valerie; Rault, Sylvain, 'Sequential Sonogashira and Suzuki Cross-Coupling Reactions in the Indole and Indazole Series', 2005, 771-780.

[29] J. Wencel-Delord, C. Nimphius, H. Wang, F. Glorius, 'Rhodium(III) and Hexabromobenzene-A Catalyst System for the Cross-Dehydrogenative Coupling of Simple Arenes and Heterocycles with Arenes Bearing Directing Groups', Angew. Chem., 
Int. Ed. 2012, 51, 13001-13005.

[30] B.-J. Li, S.-L. Tian, Z. Fang, Z.-J. Shi, 'Multiple C $\square$ H Activations To Construct Biologically Active Molecules in a Process Completely Free of Organohalogen and Organometallic Components', Angew. Chem., Int. Ed. 2008, 47, 1115-1118.

[31] D. R. Stuart, E. Villemure, K. Fagnou, 'Elements of Regiocontrol in Palladium-Catalyzed Oxidative Arene Cross-Coupling', J. Am. Chem. Soc. 2007, 129, 12072-12073.

[32] Y. Kita, K. Morimoto, M. Ito, C. Ogawa, A. Goto, T. Dohi, 'Metal-Free Oxidative CrossCoupling of Unfunctionalized Aromatic Compounds', J. Am. Chem. Soc. 2009, 131, 16681669.

[33] D. Kalyani, N. R. Deprez, L. V Desai, M. S. Sanford, 'Oxidative C-H Activation/C-C Bond Forming Reactions: Synthetic Scope and Mechanistic Insights', J. Am. Chem. Soc. 2005, $127,7330-7331$.

[34] O. Daugulis, V. G. Zaitsev, 'Anilide ortho-Arylation by Using C-H Activation Methodology', Angew. Chem., Int. Ed. 2005, 44, 4046-4048.

[35] Y. Fukui, P. Liu, Q. Liu, Z.-T. He, N.-Y. Wu, P. Tian, G.-Q. Lin, 'Tunable Arylative Cyclization of 1,6-Enynes Triggered by Rhodium(III)-Catalyzed C-H Activation', J. Am. Chem. Soc. 2014, 136, 15607-15614.

[36] N. Guimond, S. I. Gorelsky, K. Fagnou, 'Rhodium(III)-Catalyzed Heterocycle Synthesis Using an Internal Oxidant: Improved Reactivity and Mechanistic Studies', J. Am. Chem. Soc. 2011, 133, 6449-6457.

[37] V. P. Semenov Ratner, O.B., Ogloblin, K.A., 'Photochemical Decomposition of Aroyl Azides in Methanol', 1979, 15, 1870-1873.

[38] H. Zhong, D. Yang, S. Wang, J. Huang, 'Pd-catalysed synthesis of isoquinolinones and analogues via $\mathrm{C}-\mathrm{H}$ and $\mathrm{N}-\mathrm{H}$ bonds double activation', Chem. Commun. 2012, 48, 32363238 .

[39] S. Rakshit, C. Grohmann, T. Besset, F. Glorius, 'Rh(III)-Catalyzed Directed C-H Olefination Using an Oxidizing Directing Group: Mild, Efficient, and Versatile', J. Am. Chem. Soc. 2011, 133, 2350-2353. 
7. Spectra of new compounds 
1-(2-1-Methyl-1 $H$-pyrrole)-3,3-bis(trifluoromethyl)-1,3-dihydro-1 $\lambda^{3}$-benzo[d][1,2]iodaoxole (16a)

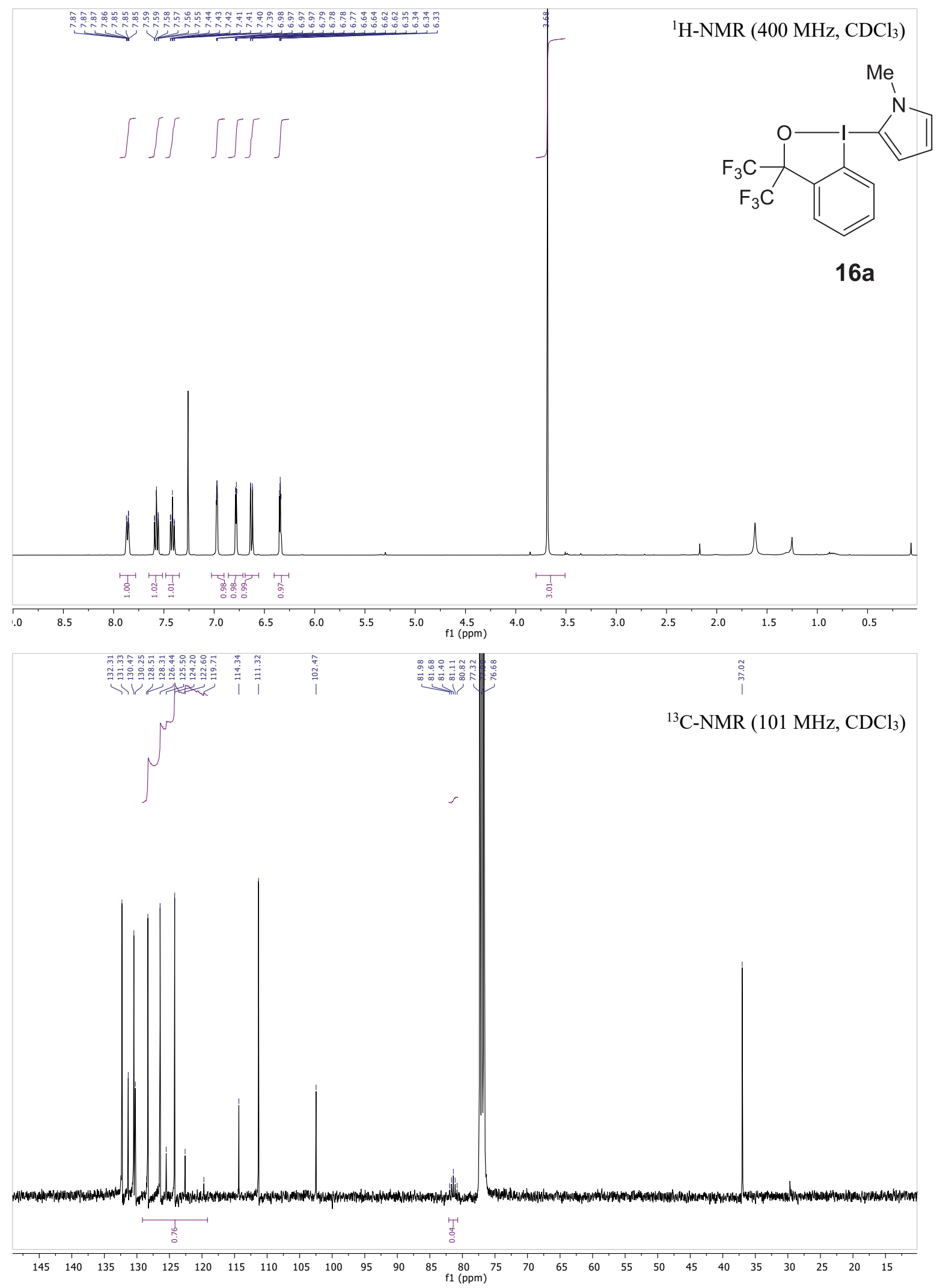

S102 


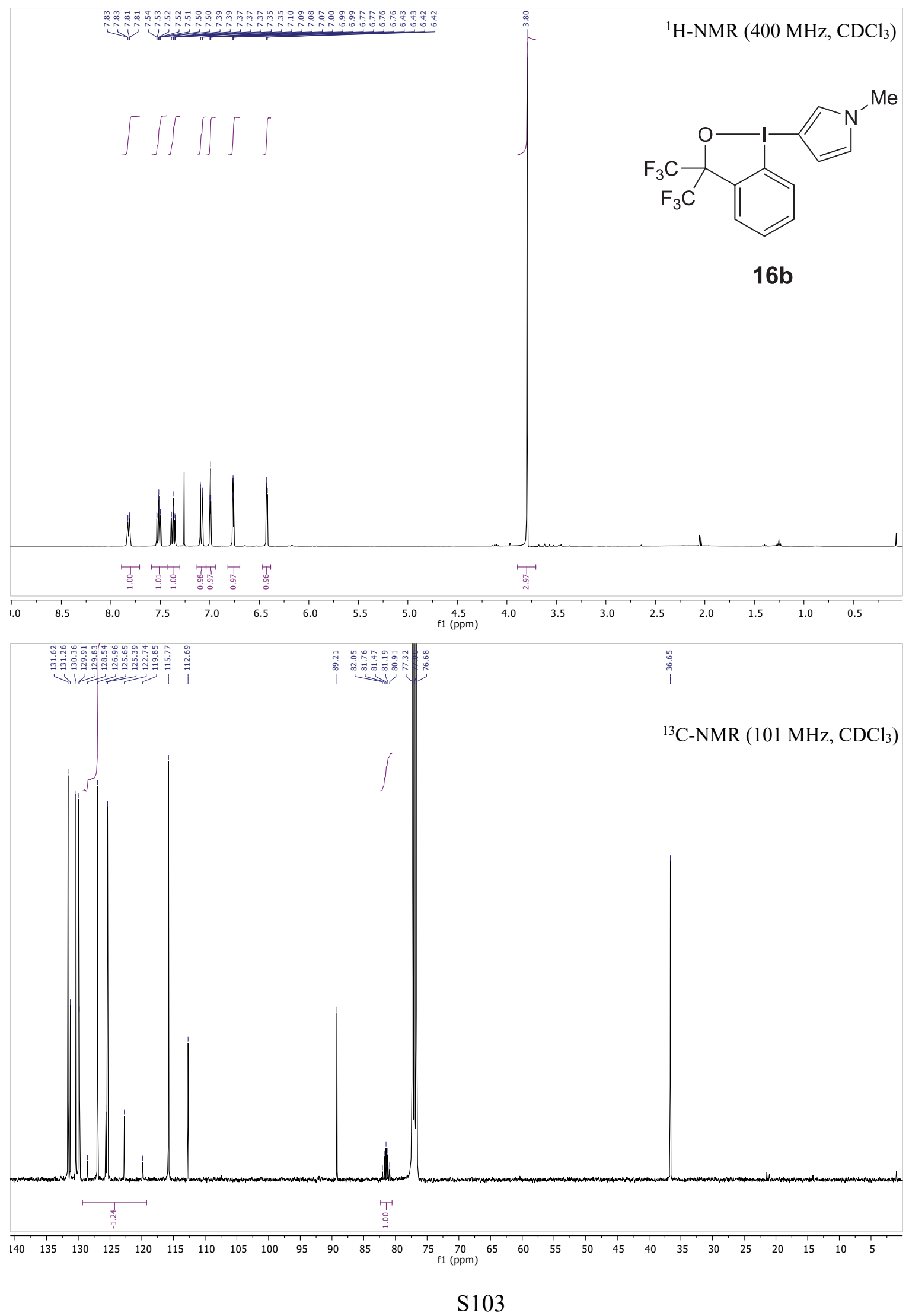


1-(3-1-Methyl-1 $H$-indole)-3,3-bis(trifluoromethyl)-1,3-dihydro-1 $\lambda_{3}$-benzo $[d][1,2]$ iodaoxole (17)

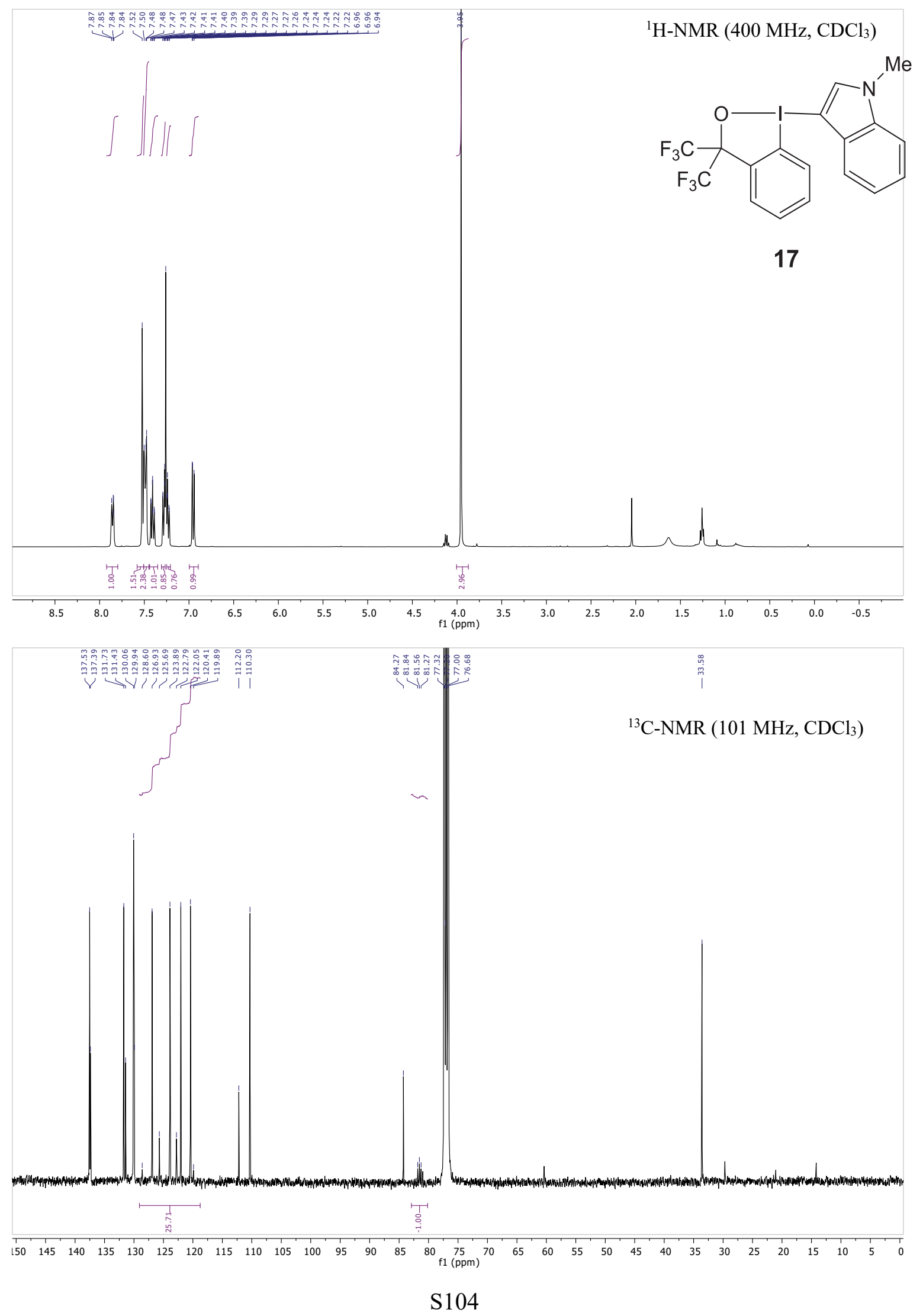



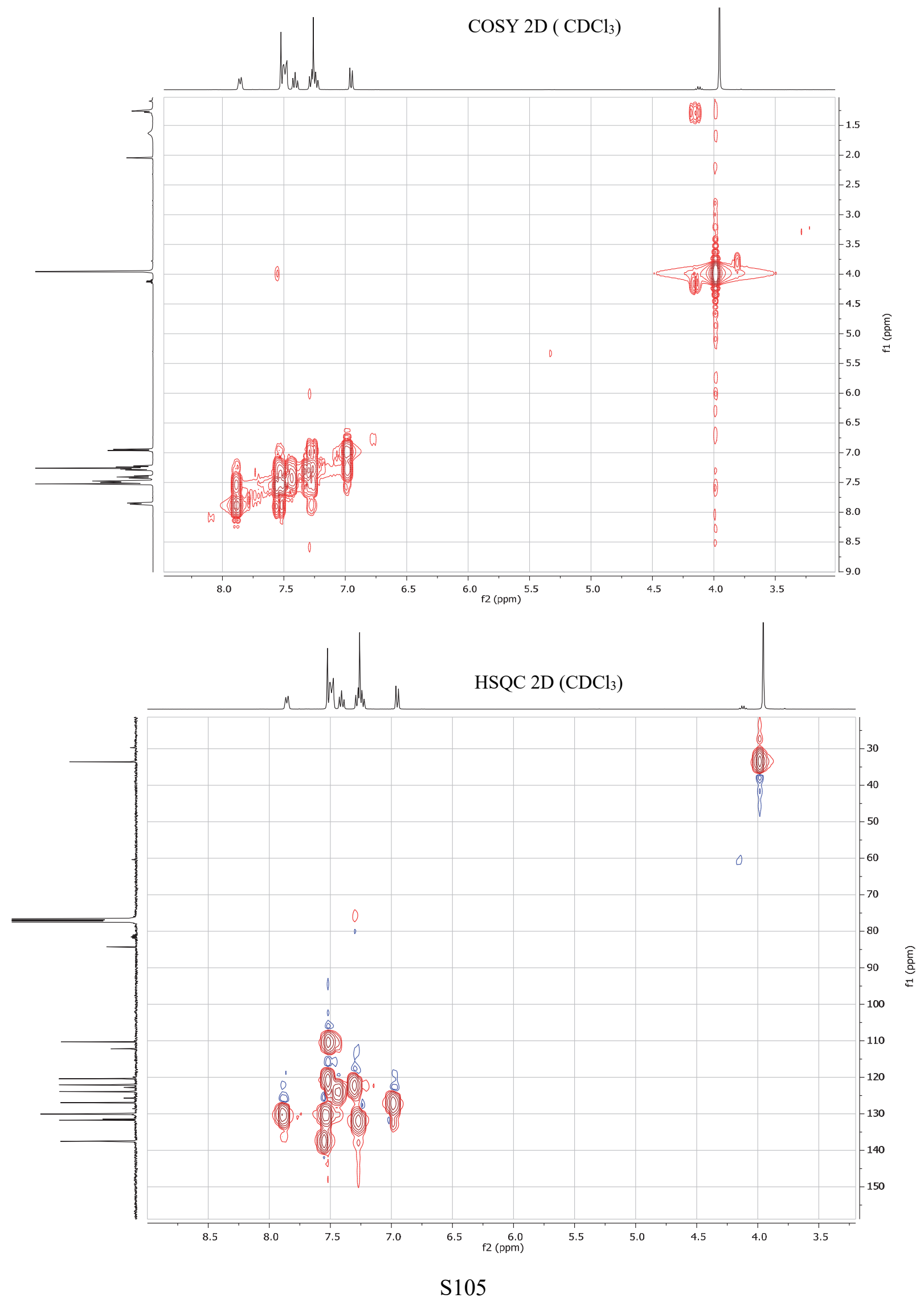


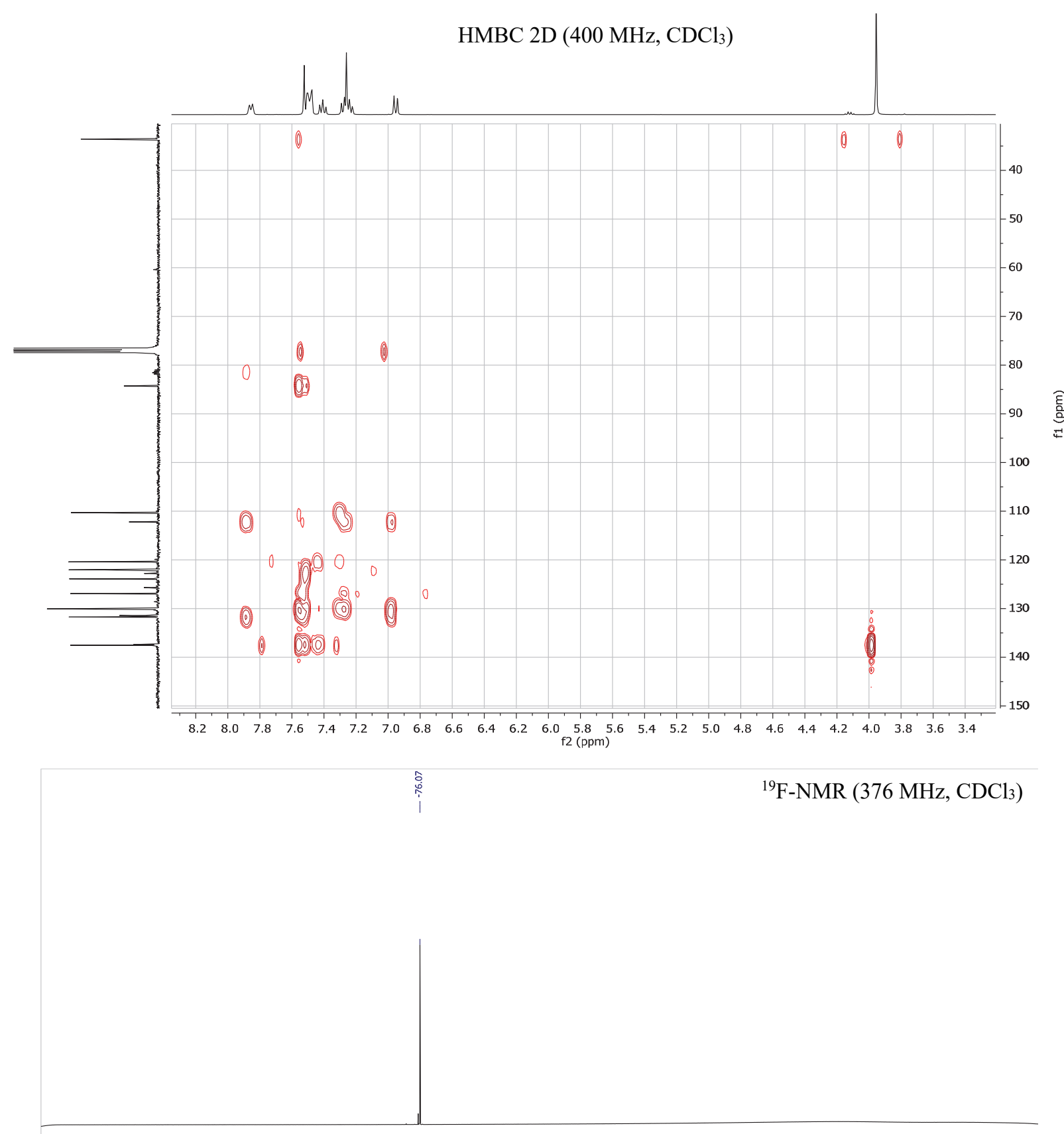

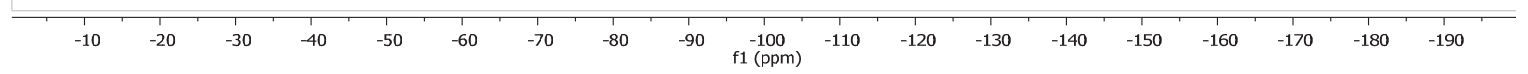
S106 


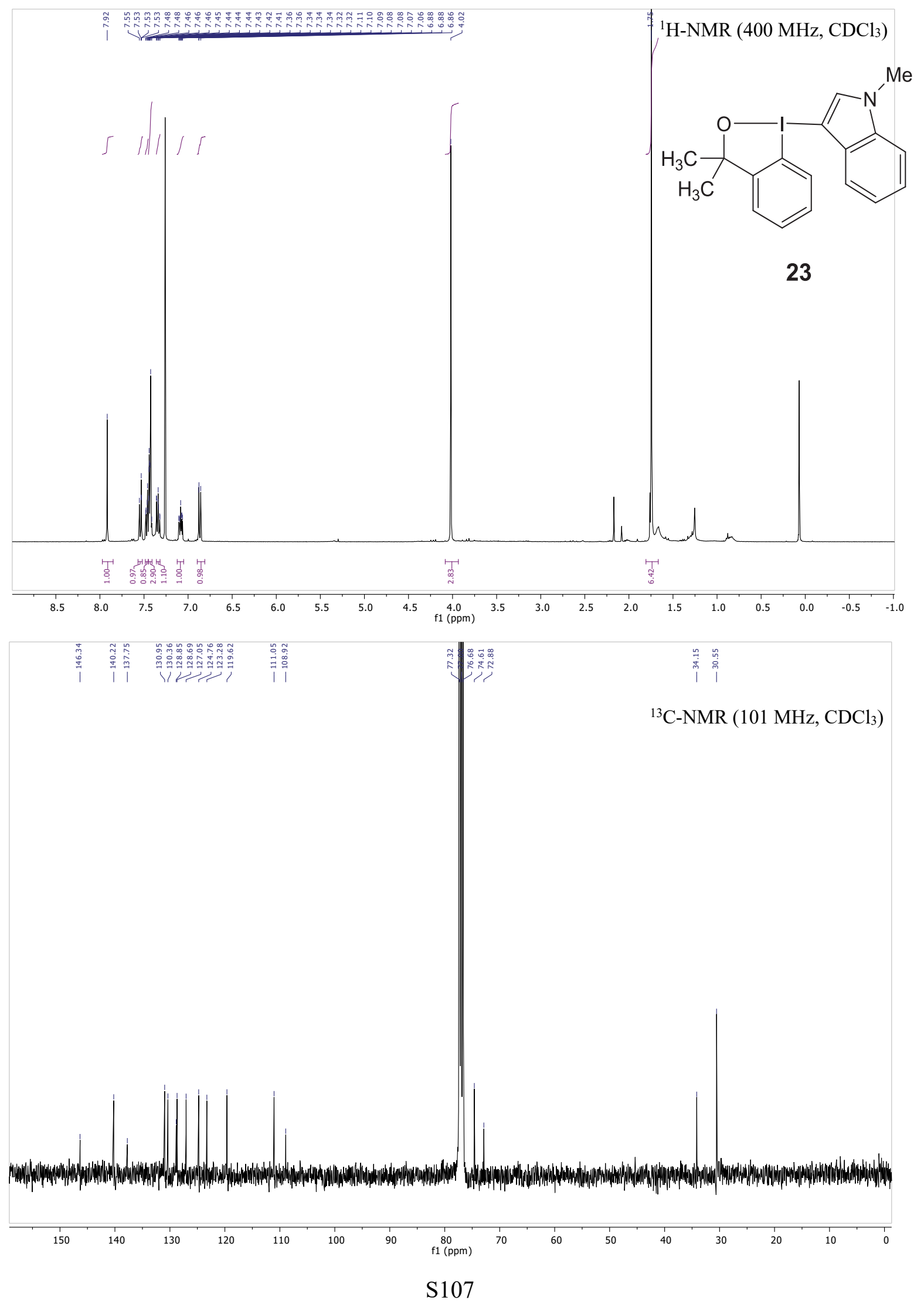


1-(2-1-Methyl-1H-pyrrole)-3,3-dimethyl-1,3-dihydro-1 $\lambda^{3}$-benzo $[d][1,2]$ iodoxole (38a) and 1-(3-1methyl-1H-pyrrole)-3,3-dimethyl-1,3-dihydro-1 $\lambda^{3}$-benzo $[d][1,2]$ iodoxole $(38 \mathrm{~b})$

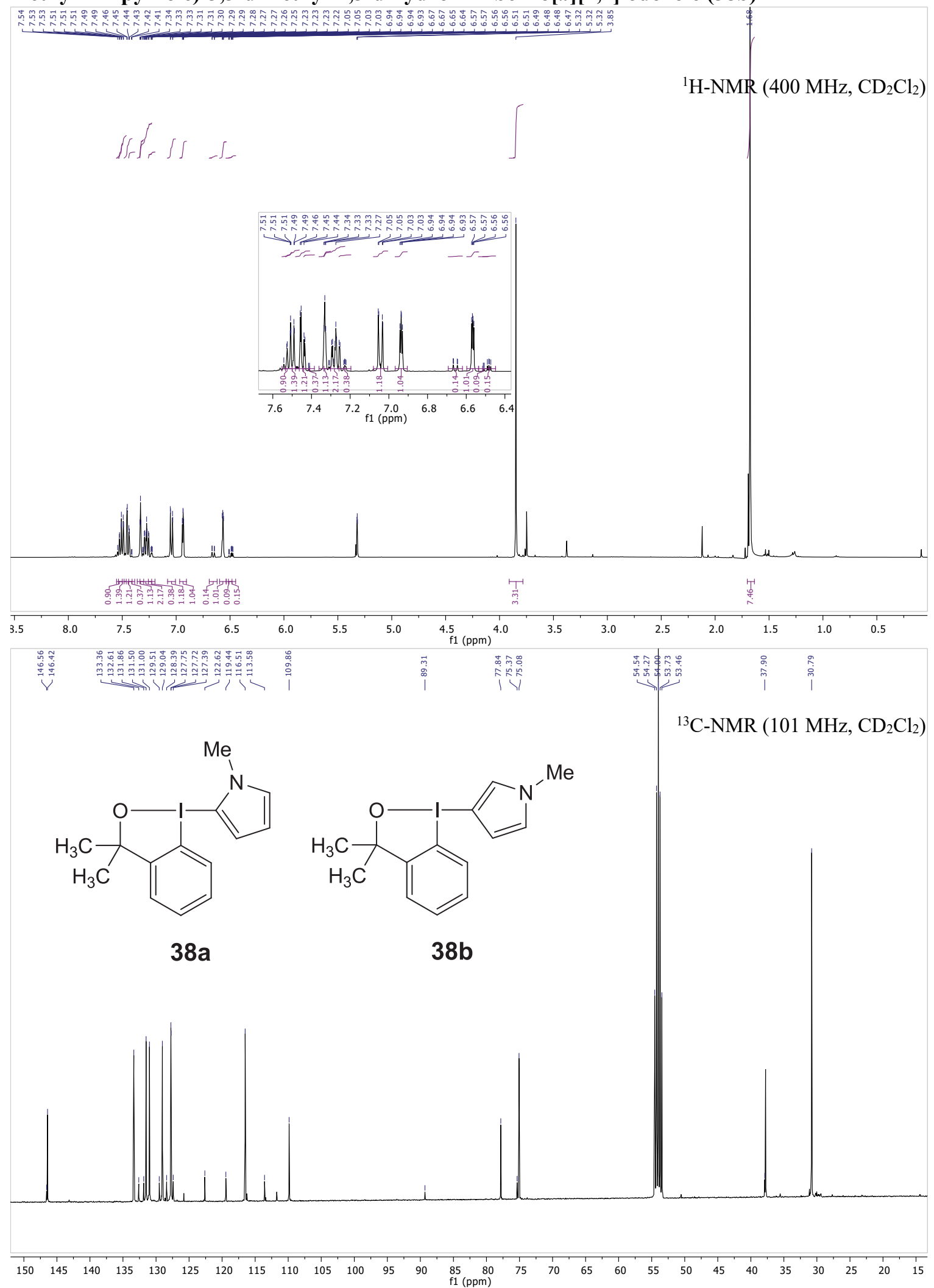


5,6-Dimethoxy-1-(3-1-Methyl-1H-indole)- $1 H$-1 $\lambda_{3}$-benzo[b]iodo-3(2H)-one (39)

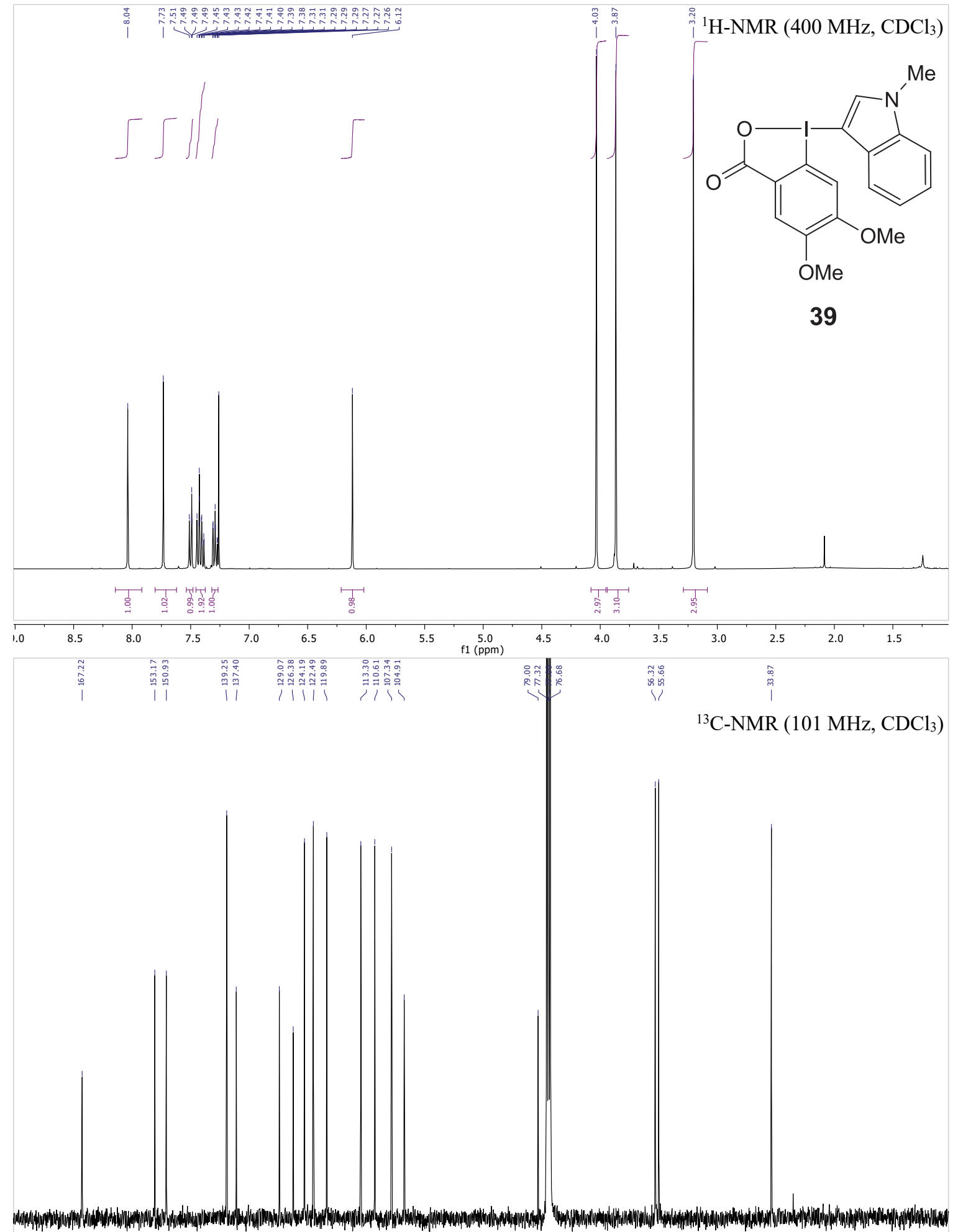

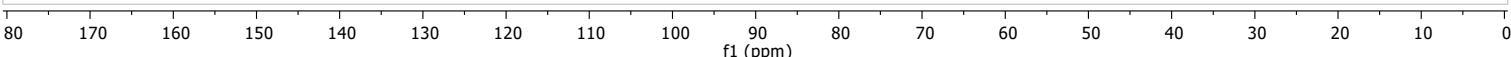


5,6-Dimethoxy-1-(2-1-methyl-1H-pyrrole)- $1 H-1 \lambda_{3}$-benzo[b]iodo-3(2H)-one (40a)
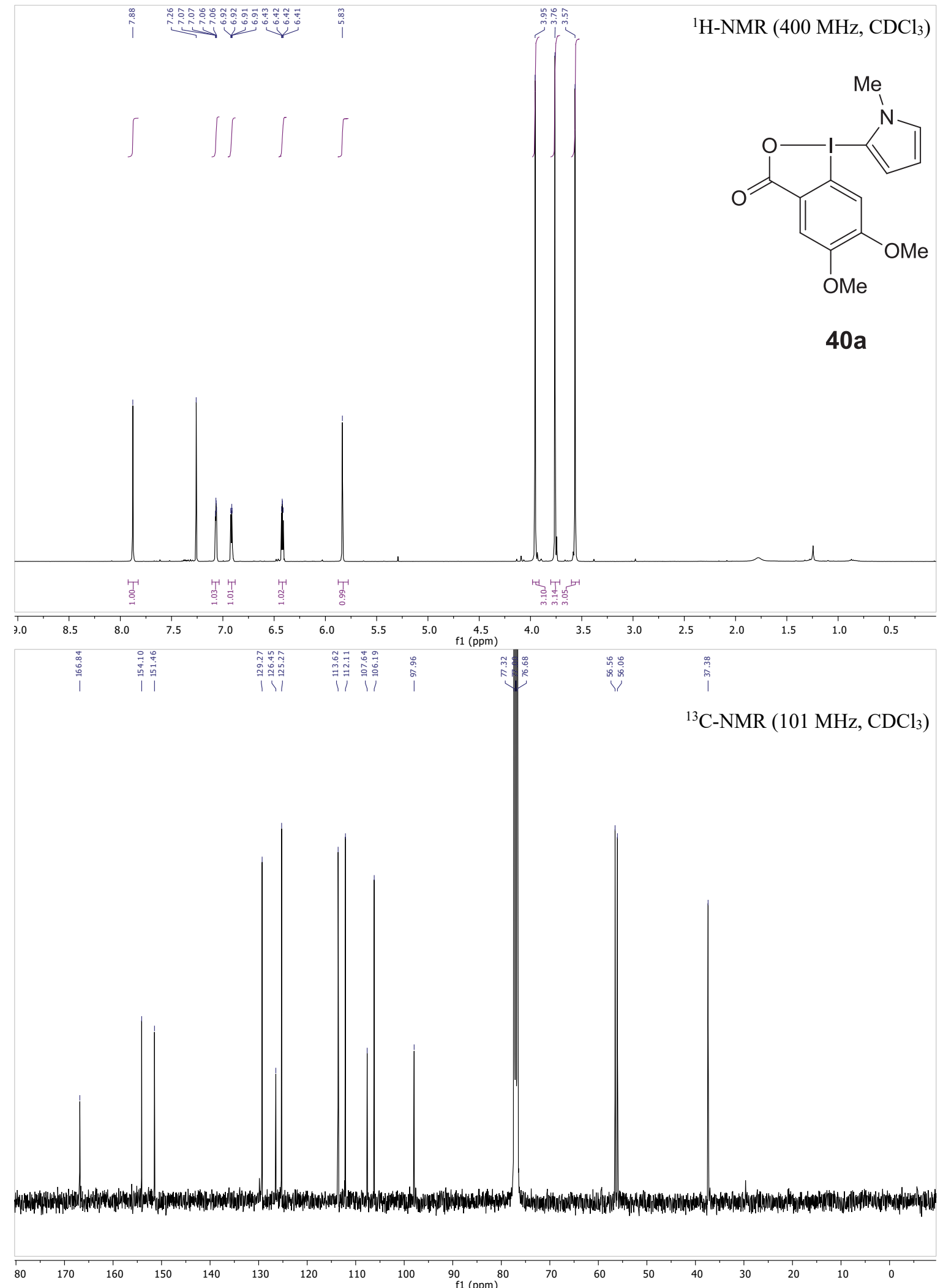

S110 
5,6-Dimethoxy-1-(3-1-methyl-1 $H$-pyrrole)- $1 H-1 \lambda_{3}$-benzo[b]iodo-3(2H)-one (40b)

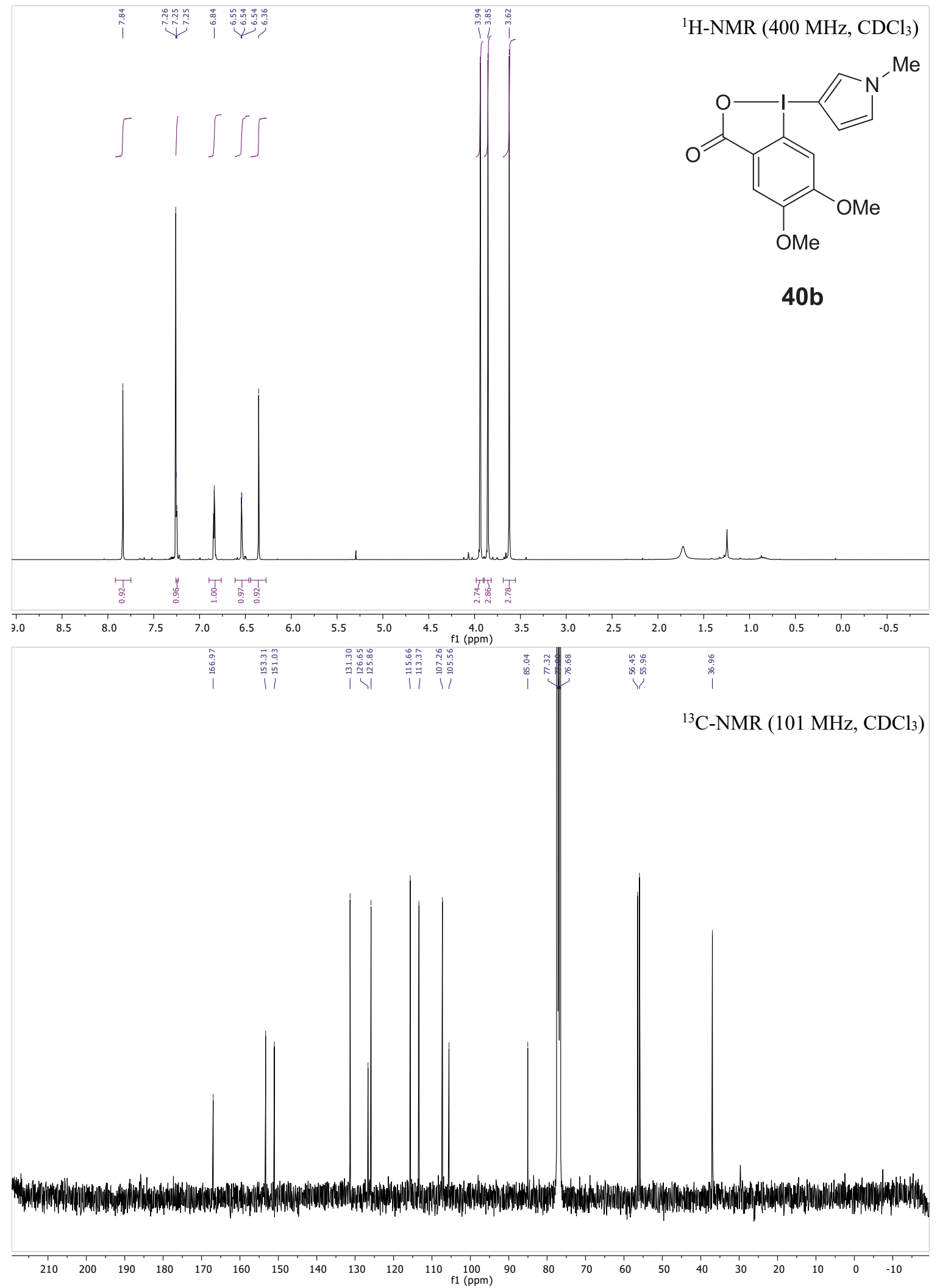


4-Fluoro-1-(2-1-methyl-1 $H$-pyrrole)- $1 H-1 \lambda_{3}$-benzo[b]iodo-3(2H)-one (41a)

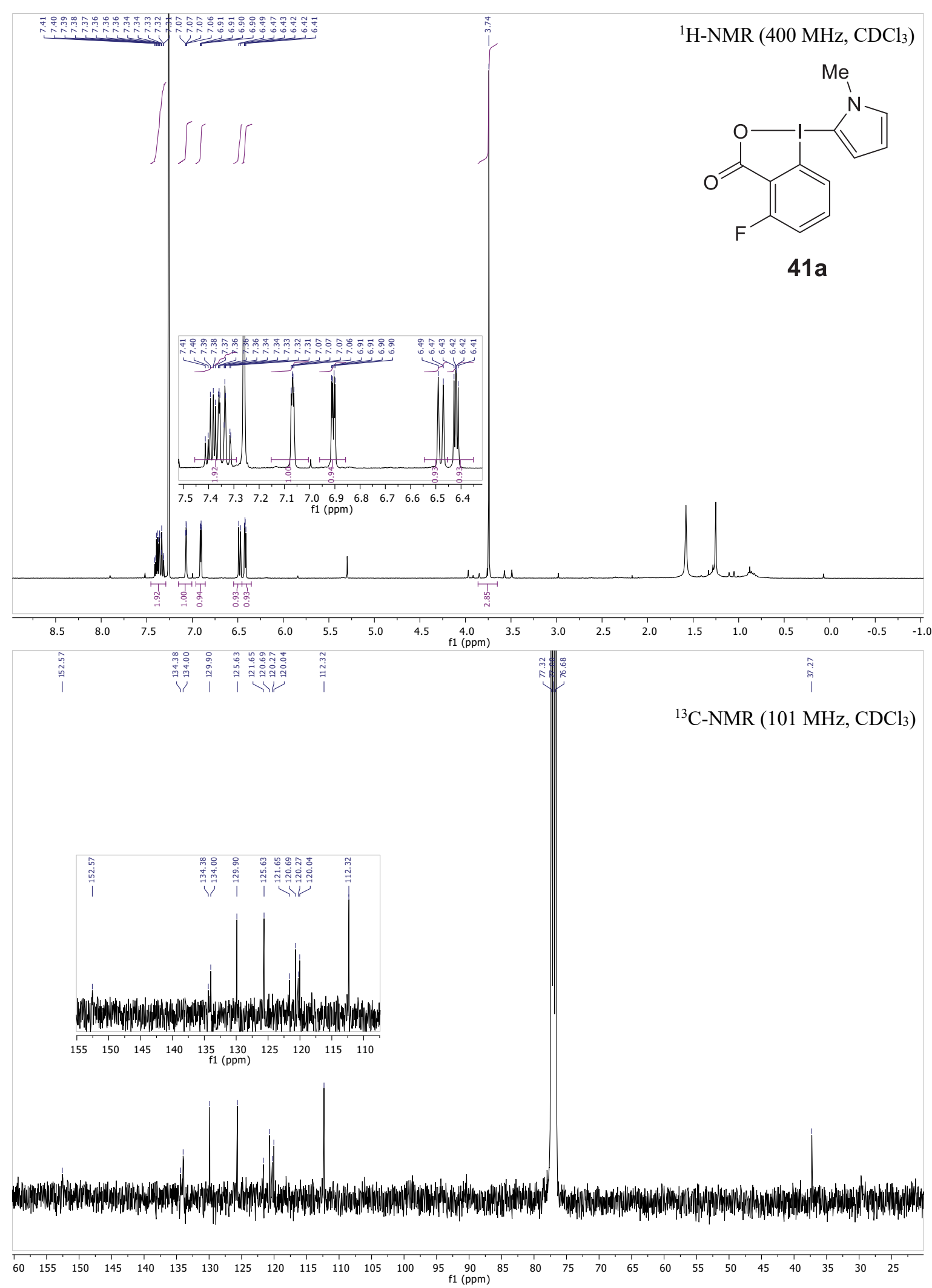

$\mathrm{S} 112$ 
4-Fluoro-1-(3-1-methyl-1H-pyrrole)- $1 H-1 \lambda_{3}$-benzo[b]iodo-3(2H)-one (41b)

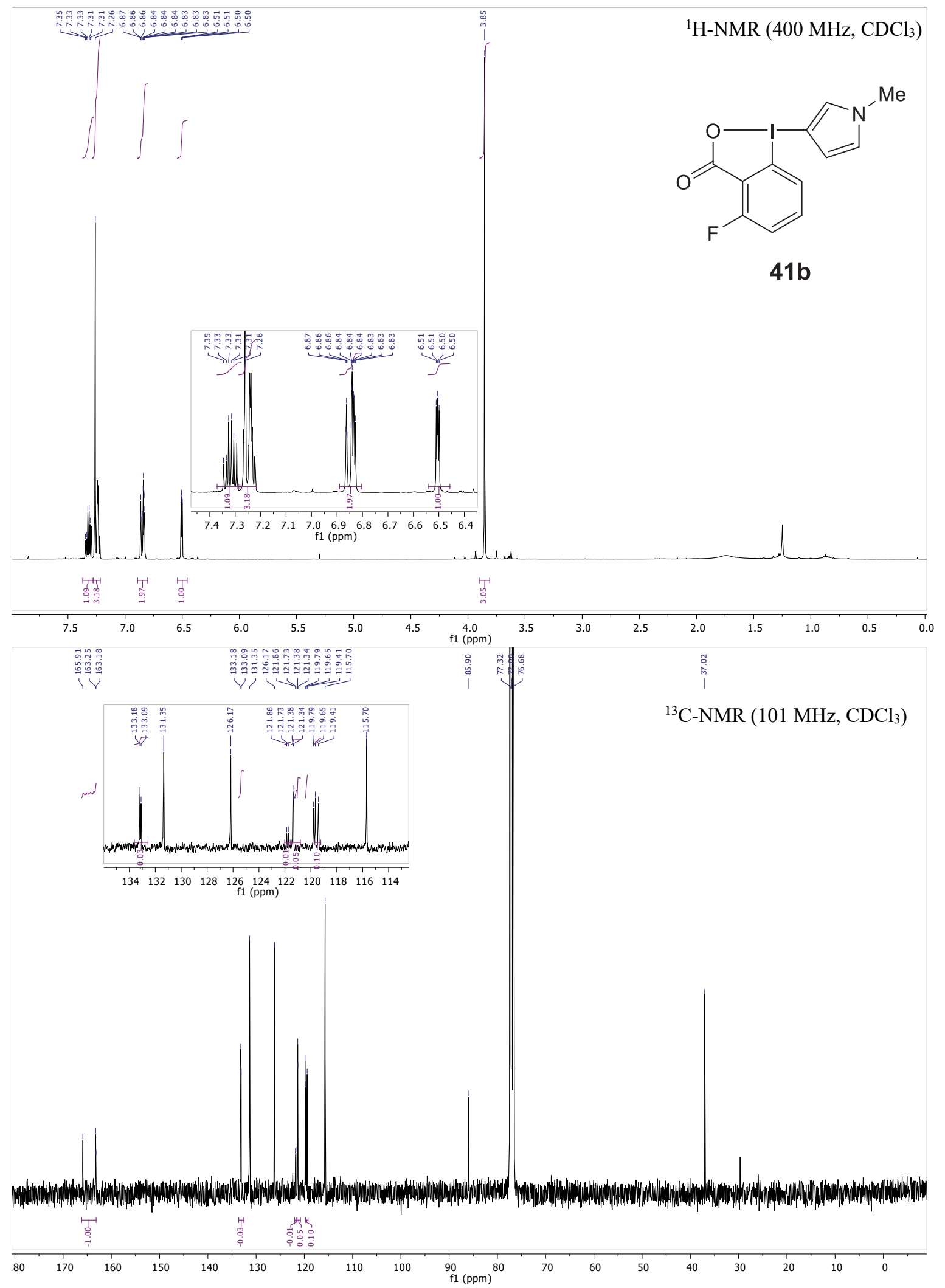

S113 
5-Nitro-1-(2-1-Methyl-1 $H$-pyrrole)-1 $H$-1 $1 \lambda_{3}$-benzo $[d][1,2]$ iodoxol-3-one (42a)

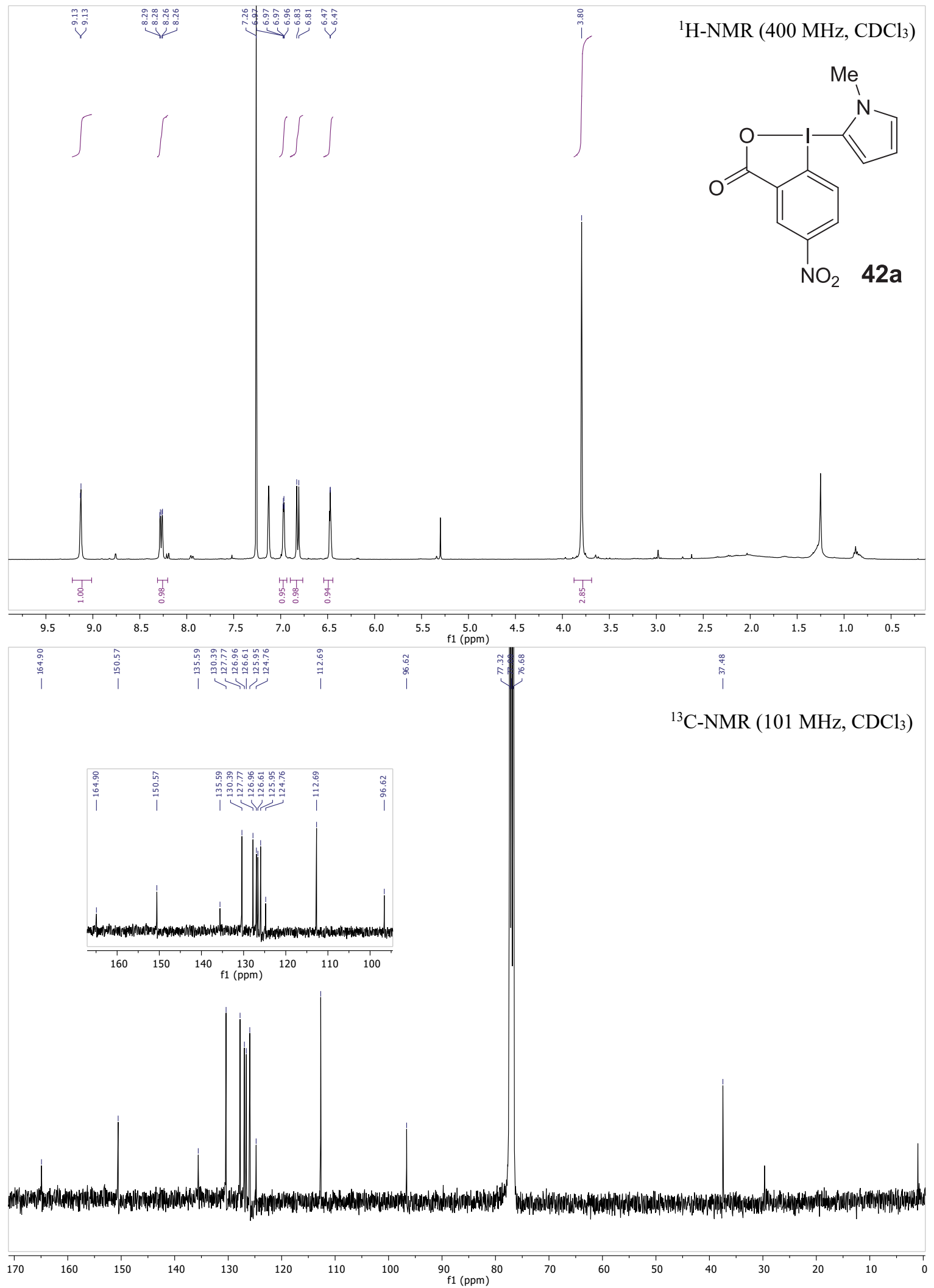

S114 
5-Nitro-1-(3-1-methyl-1H-pyrrole)-1 $H$-1 $\lambda_{3}$-benzo[d][1,2]iodoxol-3-one (42b)

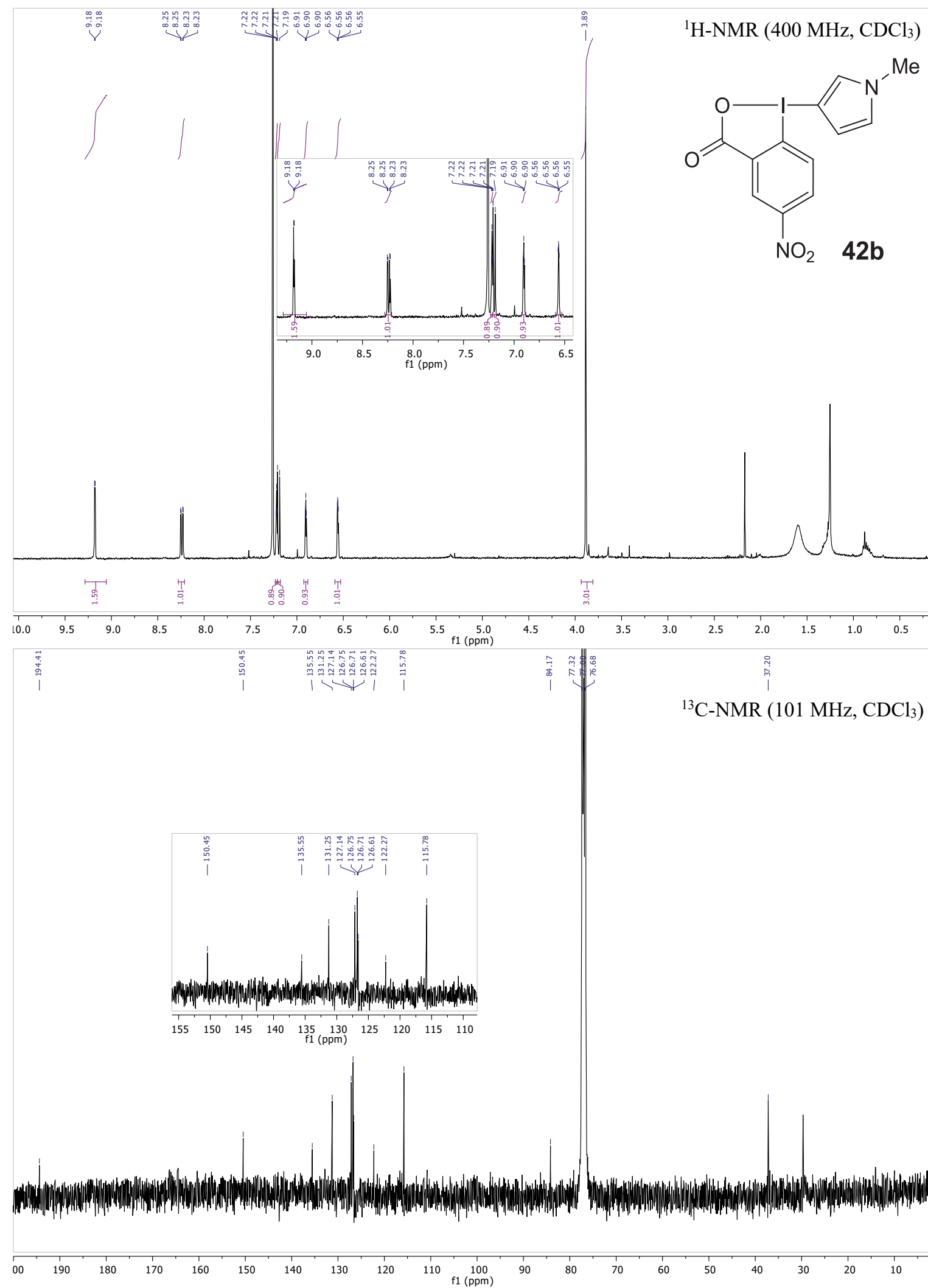


1-(2-D-1-methylindole)-1H-1 $\lambda_{3}$-benzo[b]iodo-3(2H)-one (49)

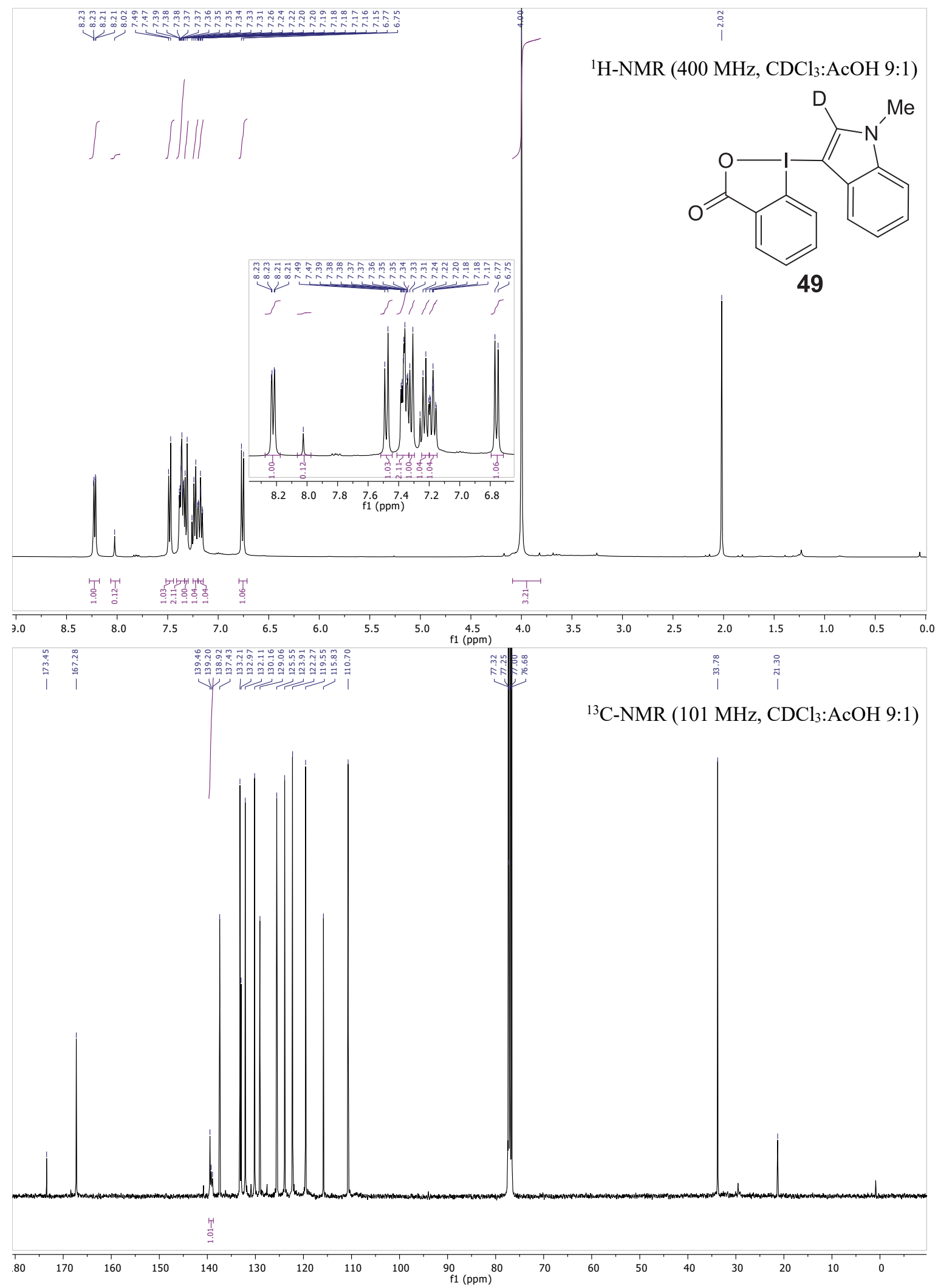

S116 